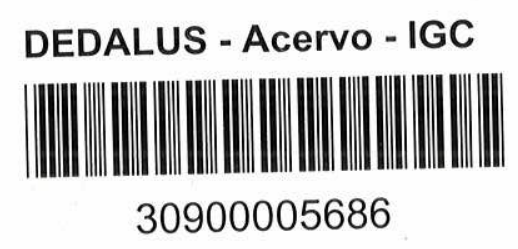

T430

\title{
GEOLOGIA E GÊNESE DO PROTOMINÉRIO E DO MINÉRIO DA PROVÍNCIA MANGANESÍFERA DE ARACOIABA - PACAJÚS, NO ESTADO DO CEARÁ
}

\author{
por \\ JOSÉ VITORINO DE SOUZA
}

Tese de Doutoramento apresentada ao Instituto de Geociências da Universidade de São Paulo. 
ESTA TESE FOI ORIENTADA POR:

DOUTOR EVARISTO RIBEIRO FILHO

PROFESSOR TITULAR DA UNIVERSIDADE DE SÃO PAULO 
Aos meus filhos:

Adriana, Sérgio

Rosana e Cristiane 
Pãgina

INDICE

AGRADECIMEN'IOS

1

RESUMO

IV

1 - INTRODUÇAO

1.1 - OBJETIVO

1.? - JUSTIFICATIVA 1

1.3 - FINALTIDAII: 2

1.4 - DEFINIÇAO DE TERMOS 2

2 - CARACTERISticas gerais DA AREA

2.1 - LOCALIZAÇĀO, ACESSO E DTMENSÕES 4

2.2 - MSPECTOS FISTOGRAFICOS 9

2.2 .1 - GEOMORFOLOGIA 9

2.2 .2 - CLIMA 12

2.2 .3 - VEGETAÇAO E SOLO 15

2.2 .4 - REDE HIDROGRAFICA 17

3 - HISTORICO DA PROSPECCXO DA RREA 17

4 - REVISAO BIBLIOGRAFICA 20

5 - METODOLOGIA 24 
5.1 - TRABALHO DE CAMPO

5.2 - DETERMINAÇÃo DE MINERAIS E TEXTURAS 26

5.3 - ANALISES QUIMICAS 27

5.4 - ESTUDO DE FALHAS TRANSCORRENTES 28

7.2 - DESCRIÇÃO DE POÇOS E FIIROS DE SONDA 38

7.2 .1 - POÇOS 38

7.2 .2 - FUROS DE SONDA 45

7.3 - PETROGRAFIA 45

7.3 .1 - ENCAIXANTES 45

7.3 .1 .1 - MIGMATITO-GNAISSE 45

7.3.1.2 - MIGMATITO-GNAISSE, MIGMATITOBASICO E METABASITO DA REGIAOO DE CHOROZINHO (PACAJOS) 49

7.3 .1 .3 - QUARTZITOS 51

7.3 .2 - PROTOMINERIO DE MANGANES 52

7.4 - MINERALOGIA DO PROTOMINERTO 56

7.5 - TEXTURAS DEPOSICIONAIS 62 
7.6 - CONDIÇðES DE METAMORFISMO

$7.6 .2-$ GONDITO

7.7 - ESTRUTURA

7.8 - AMBJENTE DE DEPOSIÇÃO DE MTNERAIS

8.2 - MINERALOGIA

8.3 - FEHCOH' TEXTURATS

8.4 - SIGNIFICAÇÃO GENËTICA DAS TEXIURAS

8.4.1 - PROCESSOS DE FORMAÇAO DO MINERIO

8.4.2 - TIPOS DE MINERIO EM RELAÇÃO AOS PROCESSOS DE FORMAÇAOO

8.4.3 - FASES E CARACTERISTICAS DO INTEM PERISMO 
ANEXO I - DESCRIÇÃO DE 17 POÇOS DAS REGIOES DE SERRAGEM, LAGOA DO RIACHO E ALTO PRETO (ARACOIA$B A-C E)$

ANEXO II - DESCRIÇAO DE 4 FUROS DE SONDA DE SERRAGEMARACOIABA

ANEXO III - DISTRIBUIÇÃO DE FREQÜENCIA DE TEORES DE Mn $\left(\frac{\circ}{0}\right)$ DE ROCHAS DA PROVINCIA DE ARACOIABA-PACAJOS (CE)

ANEXO IV - CALCULO DE a A PARTIR DE FILMES DE RAIOS-X 


\section{INDICE DAS ILUSTRAÇÕES}

\section{MAPAS}

Mapa de localização I da área com ocorrência de rochas manganesiferas - Aracoiaba e Pacajús-CE

Mapa de localização II da ārea com ocorrências de rochas manganesiferas de Aracoiaba e Pacajús-CE

Mapa de situação das ocorrências de manganês - Município de Aracoiaba e Pacajüs - CE

Mapas de isoietas (Periodo: 1911-1958 (médias anuais)

Mapa Geotectônico (Brito Neves, 1975)

Mapa Geológico da provincia manganesifera de Aracoiaba-Pacajüs (CE)

Mapa Estrutural de parte da área do Projeto Fortaleza

Mapa de localização dos poços Sexragem-Aracoiaba-CE

Esboço Geológico da ocorrência de manganês - Lagoa do Riacho-Aracoiaba-CE

FIGURAS

Figura 1 - Feições geomorfolögicas da áxea de ocorrên cias de manganês de Aracoiaba-Pacajús (CE)

Figura 2 - Variação de pluviometria (1912-1966) e tem peratura (1964-1968) - médias mensais

Figura 3 - Direções primärias de tensão, dobramento e empurrão em falhas transcorrentes 
Pāgina

Figura 4 - Deformação de $2 \underline{a}$ ordem

Figuras 5 e 6 - Sistemas tectônicos de falhas trans correntes

Figura 7 - Direção de blocos em relação ao vértice

do ângulo formado pela falha transcorrente

e pelo eixo de dobramento secundário

Figura 8 - Falha dextrógira de Senador Pompeu

Figura 9 - Dobramento de 2 a ordem formando $15^{\circ} \mathrm{com}$ a falha transcorrente de Senador Pompeu

Figura 10- Isócronas para os gnaisses e migmatitos das regiões de Quixadá e Banabuiu

Figura 11- Diagrama isocrônico para rochas da faixa Jaguaribe e maciço de Tróia

Figura 12- Perfil vertical baseado na descrição de poços escavados sobre o protominério

Figura 13- Perfil vertical baseado em descrições de poços escavados sobre gnaisse ou pegmatito

Figura 14- Migmatito-gnaisse cortado por pegmatito homogêneo concordante e por pegmatito homo gêneo discordante

Figura 15- Migmatito-gnaisse cortado por granitóide cataclástico

Figura 16- Perfil esquemático de ocorrências de mig matito-gnaisse, migmatito básico e metabasi to em Morros (Chorozinho-CE) 
Figura 17 - Perfil vertical esquemātico das ocorrências de manganês de Serragem e Lagoa do Riacho

Figura 18 - Associação mineral no sistema ${\mathrm{MnO}-\mathrm{SiO}_{2}}^{-}$ $-\mathrm{Al}_{2} \mathrm{O}_{3}$ (HÖREN, 1953)

Figura 19 - Diagrama triangular para classificação de rocha com espessartita, quartzo e anfibōlio

Figura 20 - Metamorfismo de pelitos. Setor de metamorfismo de alto grau, rico em almandina

Figura 21 - Lançamento da relação $\mathrm{FeO} / \mathrm{FeO}+\mathrm{Mgo}$ que é igual a 0,7 e 0,85 para o migmatito-gnaisse e para o silimanita quartzito respectivamente

Figura 22 - Parte hachuriada delimitando os domínios das associações 4,5 e 6 em gnanoblastitos

Figura 23 - Resultados experimentajs que mostram a influência da relação $\mathrm{Mn} / \mathrm{Ca}$ e da temperatura na formação do tipo de piroxenöide

Figura 24 - Diagrama Eh-pH para o manganês, mostrando os campos de estabilidade de óxidos, carbonatos e sulfetos

Figura 25 - Veio de óxido de manganês preenchendo vazios entre granadas

Figura 26 - I - pseudo-dobras em chevron de óxidos de manganês 
FOTOS

Foto 1 - Vista lateral do Serrote Curupira (Aracoiaba, CE) com reflorestamento de cajueiros na parte aplainada

Foto 2 - Vista parcial do Serrote Ocara, vizinho à lo calidade homônima (Aracoiaba-CE)

Foto 3 - Exfoliação do granitôide cataclāstico da Figura 15

Foto 4 - Gondito encontrado em nücleo de sinclinal en caixado por granada-quartzito, localizado no Poço 1 em Serragem (Aracoiaba, CE)

\section{FOTOMICROGRAFIAS}

Fotomicrografia 1 - Lâmina delgada mostrando granada predominante sobre quartzo em textura em mosaico

Fotomicrografia 2 - Lâmina delgada mostrando quartzo predominando sobre granada em textura em mosaico

Fotomicrografia 3 - Lâmina delgada mostrando microdo bramentos isoclinais que refletem os dobramen tos maiores

Fotomicrografia 4 - Superfície polida mostrando veios coloidais de óxidos de manganês concordantes com o acamamento geral 
Fotomicrografia 5 - Lâmina delgada mostrando silimanita e quartzo no quartzito que aflora no serrote Curupira (Aracoiaba-CE)

Fotomicrografia 6 - Lâmina delgada mostrando almandina, quartzo e biotita no migmatito-gnaisse que aflo ra no serrote Pelado

Fotomicrografia 7 - Lâmina delgada mostrando ortoclásio com exsolução de albita no metabasito

Fotomicrografia 8 - Lâmina delgada de gondito alterado mostrando granada, rodonita e mangano-cumingto nita

Fotomicrografia 9 - Lâmina delgada de gondito alterado mostrando granada, rodonita e mangano-cumingto nita

Fotomicrografia 10- Superfície polida de gondito alterado mostrando granada, quartzo e placas de 1 i tioforita e criptomelano

Fotomicrografia 11- Superfície polida de gondito alterado mostrando textura reliquiar zonada

Fotomicrografia 12- Superfície polida de gondito alterado mostrando cristais prismäticos de pirolusita pseudomorfa

Fotomicrografia 13- Superfície polida de gondito alterado mostrando pirolusita em textura de borda entre clivagens da litioforita que se situa en tre os grãos de granada 
Fotomicrografia 14 - Superficie polida de gondito alterado mostrando textura filiforme de litioforita sendo substituida por criptomelano

Fotomicrografia 15 - Superficie polida mostrando gondito alterado com textura de curvamento dos filamentos de litioforita dentro do criptomelano e de pirolusita

Fotomicrografia 16 - Superfície polida de esfera con cêntrica de óxidos de manganês, mostrando textura nodular concêntrica

Fotomicrografia 17 - Superficie polida de gondito alterado mostrando textura de bandeamento coloforme de criptomelano, apresentando formas es feroidais de silica, fendas de dessecação e textura de grânulos micrométricos de óxidos de manganês

Fotomicrografia 18 - Superficie polida de gondito alterado mostrando textura em pente de pirolusi ta, preenchendo vazios centrais de deposição coloidal de criptomelano

\section{QUADROS}

Quadro 1 - Ocorrências de minērio de manganês segundo Moraes (1973), Braga (1977) e CRUzUL (1975)

Quadro 2 - Resumo da história da prospecção da área de ocorrência de manganês de Pacajüs-Aracoiaba(CE) 
pāgina

Quadro 3 - Composição do protominério de manganês da provincia manganesifera de Aracoiaba-Pacajús (CE) 55

Quadro 4 - Coluna lito-estratigrä́ica da província manganesifera de Aracoiaba-Pacajús (CE)

Quadro 5 - Sucessão dos minerais oxidados, da província manganesífera de Aracoiaba-Pacajūs (CE)

Quadro 6 - Quadro comparativo entre os depósitos de manganês de Aracoiaba-Pacajús e as jazidas de Serra do Navio (AM), Morro da Mina (MG) e Urandi (BA)

Quadro 7 - Evolução das paragêneses sedimentar, metamórfica e supergênica do gondito da provîncia manganesiffera de Aracoiaba-Pacajús-CE

\section{TABELAS}

Tabela 1 - Dados geocronológicos para a faixa Jaguari beana e alguns dados para o maciço de Tróia

Tabela 2 - Distâncias interplanares (dA) obtidas por difração de raios $X$ (filme) em radiação $F e K \alpha$, comparadas com padrões ASTM (1965)

Tabela 3 - Distâncias interplanares $(d A)$ obtidas por difração de raios $X$ (filme) em radiação $F e k \alpha$, comparadas com padrão ASTM (1965)

Tabela 4 - Valores de diferença de $2 \theta$ para $F e K \alpha$ e sua transformação para $c u k \alpha$ relativos às granadas 
Tabela 5 - Valores de propriedades físicas de

granadas

Tabela 6 - Percentagens de composição molecular obti das de diagramas triangulares pelo método de Madureira Filho (1972) e Camargo e Madureira Filho (1976)

Tabela 7 - Percentagens obtidas a partir de diagramas triangulares, segundo mëtodo de Madureira FiIho (1972) e Camargo e Madureira Filho (1976)

Tabela 8 - Análises químicas realizadas pelo Laboratório puriquima $S / A$ e pelo Laboratörio de Química do Departamento de Mineralogia e Petrografia do Instituto de Geociências da USP

Tabela 9 - Distâncias interplanares ( $\mathrm{A} \AA$ ) obtidas por difração de raios $\mathrm{X}$ (filme) em radiação $F \in K_{\alpha}$ comparadas com padrão ASTM

Tabela 10- Distâncias interplanares (dA) obtidas por difração de raios $X$ (filme) em radiação FeKa comparadas com padrão ASTM

Tabela 11- Distâncias interplanares $(d \AA)$ obtidas por difração de raios $x$ (filme) em radiação $F e K \alpha$ comparadas com padrões ASTM

Tabela 12- Distâncias interplanares (dA) obtidas por difração de raios $X$ (filme) em radiação $F e K \alpha$ comparadas com padrões ASTM 
Página

Tabela 13 - Distâncias interplanares ( $\mathrm{A} \AA$ ) obtidas por difração de raios $X$ (filme) em radiação $F e K \alpha$ comparadas com padrões $(a, b, c$ e d)

Tabela 14 - Tabulação de dados obtidos do Anexo III para cálculo de média $(X)$ e de desvio padrão $(\sigma) \quad 119$

Tabela 15 - Valores de $\mathrm{Mn} / \mathrm{Fe}$ e de $\mathrm{SiO}_{2}+\mathrm{Al}_{2} \mathrm{O}_{3}$ de $\mathrm{P}$ para - minério da província Aracoiaba-Pacajús-CE

Tabela 16 - Resultados de análises químicas do minério de manganês da provincia de Aracoiaba-Pacajūs (CE) de acordo com a ocorrência (\%)

Tabela 17 - Resultados de anālises químicas do minério de Serragem e Lagoa do Riacho

Tabela 18 - Elementos traços no minéxio de Lagoa do Ria cho e Serragem no município de Aracoiaba (CE)

Tabela 19 - Reservas medidas de Serragem e Lagoa do Riacho (Aracoiaba-CE) conforme relatório inëdito de CRUZUL (1975) 
AGRADECIMENTOS

A execução deste trabalho foi possível devido ao esforço das seguintes entidades: universidade Federal do ceará (UFC), Universidade de São Paulo (USP), Coordenação de Aperfeiçoamento de Pessoal de Nível Superior (CAPES), Departamento de Minas do Estado do Ceará e empresa de mineração Indûstria e Comércio de Minérios S/A (ICOMI).

Da UFC, por meio do Departamento de Geociências do Centro de Ciências desta Universidade, obtive a oportunidade de afastamento por três anos.

Na USP, tanto docentes quanto funcionärios do Insti tuto de Geociências me proporcionaram ambiente e condições propícias ao estudo e elaboração desta tese. Refiro-me, especialmente aos funcionários Paulo E. Mori., Itaci Kroehen, Melany Thereza Isauk, Waldemax Lucas de Oliveira, Aparecida N. Comi, Nair de Campos Louzada, José Ponchirolli, Jaime Alves da Silva, Nícia Maria Brandão Zalaf, Maria Eugênia Rubira, José Moraes, Jaime de Souza Marques e Maria Madalena Benzi Matazo, e em particular aos professores Doutor Umberto G. Cordani, Doutor José Moacyr Vianna Coutinho, Doutor Marcos Aurēlio Farias de Oliveira, Doutor José Vicente Valarelli, Doutor Rainer Schultz, Doutor Raphael Hypólito e José Barbosa Madureira Filho, que colaboraram diretamente. Aos Professores Doutor Reinholt Ellert, Doutor Aldo da Cunha Rebouças, Doutor Nelson Ellert, Doutor Aledir Paganelli Barbour e Uriel Duarte agradeço o apoio e estimulo na realização deste trabalho.

Da CAPES recebi suporte financeiro sob a forma de bolsas de estudo durante três anos.

- Departamento de Minas da Secretaria de Obras e Serviços públicos do Estado do ceará, por meio de seus diretores Manoel Alcides Rocha e Jülio Sarmento de Menezes, forneceu - suporte financeiro para a realização dos trabalhos de campo. Faço menção especial à cessão do funcionārio João Lopes da sil- 
va, prospector do Departamento de Minas e grande conhecedor da ārea de manganês, que gentilmente me acompanhou durante a fase de reconhecimento geológico e sempre esteve disposto a ajudar.

Agradeço a ICOMI S/A que permitiu, de bom grado, a leitura dos originais de seus relatórios de pesquisa feitos em cumprimento às exigências do Código de Mineração.

Agradeço especialmente às colegas de pös-graduação, Rosa Maria Silveira Bello e Ana Maria Dreher.

Ao Professor Doutor Evaristo Ribeiro Filho agradeço a execução das fotomicrografias que ilustram esta tese. 
De maneira especial, agradeço ao professor Doutor Evaristo Ribeiro Filho, pela orientação e apoio dispensados durante a realização do curso de doutorado na Universidade de são paulo, bem como pela orientação durante todas as fases da execução da presente tese.

A minha esposa, Givanilda Aquino de Souza que ajudou e acompanhou passo a passo a realização deste trabalho. 
RESUMO

Este trabalho foi desenvolvido principalmente nas localidades de Serragem e Lagoa do Riacho no município de Aracoiaba (CE), abrangendo também, em alguns aspectos, toda a província manganesifera de Aracoiaba-Pacajús no nordeste do Estado do Ceará.

o trabalho tem como objetivo principal a caracterização paragenética e textural do protominério oxidado de manganês a fim de definir sua gênese e intemperismo.

A litologia regional é formada por migmatito-gnaisse, granada-silimanita-cquartzitos e metabasitos. De maneira restrita são encontrados gonditos alterados juntamente com granada-quartzitos encaixados no migmatito-gnaisse cortado por pegmatitos homogêneos.

o gondito, de direção $\mathrm{N} 20^{\circ} \mathrm{W}$ e mergulho de $50^{\circ}$ a $75^{\circ}$ para leste, foram situados estrutural e estratigraficamente no Complexo Caicö.

O metamorfismo regional é de fácies granulitica com superimposição de fácies anfibolito com pressão e temperatura minimas respectivas de $6 \mathrm{~kb}$ e $600^{\circ} \mathrm{C}$.

o gondito é composto essencialmente de espessartita, quartzo, rodonita e mangano-cumingtonita e acessoriamente de grafita, pirita e pirrotita.

o gondito foi originalmente depositado em bacia restrita de ambiente redutor; em seguida foi submetido a, pelo menos, duas fases de metamorfismo. Posteriormente, foi submetido a intemperismo formando minério oxidado constituído de litioforita, criptomelano, pirolusita e mangano-nsutita.

As principais texturas do gondito aqui descritas são: Textura em mosaico, textura bandeada (deposicionais) e texturas reliquiares, de borda, coloformes, nodular concêntrica, em reta- 
lhos, brechada, filiforme, em pente e em boxwork (pós-deposicionais).

Em função das texturas foram configurados três processos de formação do minério: Processo de Substituição, processos de preenchimento de cavidades e de laterização.

Os minērios foram classificados como minérios "in situ" (Afloramentos de gondito alterado) e minérios residuais (Blocos rolados e esferas concêntricas).

o teor do minério varia de 18 a 38\% de $\mathrm{Mn}$, sendo o teor mëdio da província de 23\% de Mn. Isoladamente as ocorrências de Serragem e Lagoa do Riacho têm um teor médio de $28 \%$ de $\mathrm{Mn}$.

A tonelagem para a provincia é baixa. O maior depósito (Lagoa do Riacho) possui uma reserva medida de 370000 t de minério bruto a $28 \%$ de $\mathrm{Mn}$, $50 \%$ das quais são de minério residual.

Tendo em vista o baixo teor e a pequena reserva, conclui-se que o minério é aproveitável economicamente em pequenas siderurgias próximas aos depósitos. 
1 - INTRODUÇAOO

\section{1 - OBJETIVO}

Esta tese é fruto do trabalho que foi desenvolvido na província manganesifera de Aracoiaba-Pacajús, nordeste do Estado do Ceará. Irata-se de uma investigação geológica que tem como objetivo principal a caracterização paragenētica e textural do protominërio oxidado, com o fito de definir sua gênese e intemperismo, bem como tecer considerações sobre uma eventual possibilidade de aproveitamento econômico.

\section{2 - JUSTTFICATIVA}

Ultimamente se intensificaram as pesquisas de caracterização de protominērios de manganês em território brasileiro. Foram desenvolvidos vários trabalhos sobre origem e composição de protominērios sillico-carbonäticos, que condicionaram a formação de jazidas de manganês de serra do Navio, no Territörio Federal do Amapá (BELLO et al., 1976; BARBOUR, 1965; CASTRO, 1963; DORR, 1949; LEINZ, 1948; NAGELL, 1961 e 1962; PARK, 1951 e 1956; SCARPELLI, 1966 e 1973; SILVA et al., 1963; VALARELII, 1963, 1966 e 1967).

Outras pesquisas foram feitas a respeito de gonditos e queluzitos que ocorrem em Minas Gerais, principalmente no municipio de Conselheiro Lafaiete, na localidade de Morro da Mina. Entre os precussores destacam-se DERBY (1901) e (1908),OLIVEIRA (1929) e GUIMARÃES (1929) e (1935); entre os mais recentes estão BITTENCOURT (1973), COUTINHO et al. (1976), DORR (1968), EBERT (1963) HERTZ (1973), HOREN (1953), MELFI et al. (1973) e (1975), ÖDMAN (1955) e PIRES et al. (1970). 
Sobre os depösitos de manganês no sul do Estado da Bahia, foram realizadas pesquisas mais recentes (RIBEIRO FILHO, 1968, 1976 e 1977; RIBEIRO FILHO \& VALARELLI, 1966 e MACHADO, $1977)$.

vārios outros autores discorreram sobre a origem das jazidas de manganês de Urucum, em Corumbã, no Estado de Mato Grosso e a de Maraü, no Estado da Bahia (ALMEIDA, 1946; DORR, 1945; GONÇALVES, 1972; TONIATI, 1973 e VALARELLI, 1976).

Neste contexto, o presente trabalio se propõe a preencher uma lacuna quanto aos estudos genéticos das ocorrências de manganês de Aracoiaba-Pacajūs (CE). Foram estudadas amostras de rochas das ocorrências de serragem e lagoa do Riacho (Aracoiaba), distantes entre si $12 \mathrm{~km}$. Alēm disso, foram coletadas amostras de outros depōsitos na mesma região a fim de se fazer interrelações de resultados conseguidos na ärea principal e em toda a província.

\section{3 - FINALIDADE}

A finalidade precípua desta investigação é oferecer um conjunto de informações interpretadas, que, juntamente com os dados jā existentes, servirão para orientar trabalhos de prospecção na área ou em āreas semelhantes no Estado do Ceará.

\section{4 - DEFINIÇAO DE TERMOS}

Neste item são definidos alguns termos utilizados no desenvolvimento do trabalho e que são passiveis de interpretação dübia.

Associação mineral - é o conjunto de minerais em uma rocha. Pode encerrar värias paragêneses (ROUTHIER, 1963). 
Estruturas - Significa feições maiores observađas mesoscópica ou macroscopicamente (BASTIN, 1950).

Falha transcorrente - E uma ruptura na crosta terrestre, na qual o movimento dominante de um bloco em relação ao outro é horizontal, e os planos de falha são essencialmente verticais (ANDERSON, 1951 apud MOODY, 1973).

Foliação - Significa qualquer tipo de paralelismo de minerais ou massas de minerais em rocha metamörfica ou ígnea (LOCZY et al., 1976).

Gondito - Rocha parametamörfica composta principalmente de espessartita, quartzo, piroxenóide e anfibólio(HoLTROP, $1965)$.

Minério de manganês - Significa o conjunto de minerais de manganês depositados como óxidos, de forma enriquecida em relação ao protominério e dos quais pode ser extraído o $\mathrm{Mn}$ (HOLTROP, 1965).

Minério residual - Minērio formado por intemperismo e enriquecimento do protominério, que não sofreu transporte ou se encontra vizinho ao afloramento (HOLTROP, 1965).

Paragênese - E o conjunto de minerais de uma rocha resultante de um determinado processo geológico ou geoquímico (ROUTHIER, 1963).

Protominério de manganês - E a rocha a partir da qual são dissolvidos os compostos de manganês que são depositados de forma enriquecida (HOLTROP, 1965).

Provincia manganesifera - Estes dois termos são usados em sentido lato para se referix à ärea que contém vārios depósitos de manganês com um relacionamento genético entre si ( $\mathrm{Ba}-$ seado em TURNEAURE, 1955).

Sucessão Mineral - E a ordem segundo a qual são depositados os minerais da paragênese durante o desenvolvimento de um processo geológico e geoquímico (ROUTHIER, 1963).

Texturas - São feições menores dependentes de tamanho, 
forma e arranjo dos grãos dos minerais, e em alguns casos feições como clivagem mineral, contatos entre minerais e fraturamentos menores observados ao microscópio ou em amostra de mão (BASTIN, 1950).

2 - CARACTERISticAs gerais DA AREA.

\section{1 - LOCALIZAÇAO, ACESSO E DIMENSÖES.}

A província manganesiffera de Aracoiaba-Pacajús (CE) pode ser localizada nos seguintes mapas topográficos, editados pela SUDENE (1970) em escala 1/100.000: SB -24-X-I (Baturité), $\mathrm{SB}-24-\mathrm{X}-\mathrm{II}$ (Beberibe), $\mathrm{SB}-24-\mathrm{X}-\mathrm{A}-\mathrm{IV}$ (Itapiūna) e $\mathrm{SB}-24-\mathrm{X}-\mathrm{A}-\mathrm{V}$ (Bonhu).

A ārea onde foi executado o reconhecimento geológico para esta tese está definida por um retângulo de $18,5 \mathrm{~km}$ de largura (E-EW) por $57,0 \mathrm{~km}$ de comprimento $(\mathrm{N}-\mathrm{S})$, que, por sua vez, está delimitado pelas seguintes coordenadas; $38^{\circ} 25^{\prime}$ e $38^{\circ} 35^{\prime}$ (L.W.) e $4^{\circ} 10^{\prime}$ e $4^{\circ} 40^{\prime}$ (L.S.). Os depósitos de manganês se alinham numa faixa diagonal dentro deste retângulo, com direção NNE-SSW, medindo aproximadamente $4 \times 50 \mathrm{~km}$ (Vide Mapa de Localização I, pág. 5 ).

Na Folha SB-24-X-A DNPM, em escala $1 / 250.000$, a ārea se situa na parte central (Vide Mapa de Localização II, pág. 6.

A localidade de Serragem no distrito de Curupira(Aracoiaba) é o centro geogräfico de todas as ocorrências da província manganesifera, possuindo as seguintes coordenadas: $38^{\circ} 30^{\prime}$ (L.W.) e $4^{\mathrm{O}} 30^{\prime}$ (L.S.).

A ocorrência de Lagoa do Riacho localiza-se $12 \mathrm{~km}$ ao sul de Serragem, no mesmo distrito; é conhecida também por "Mata da vaca".

Para locàlização de qualquer ocorrência é necessārio 
MAPA DE LOCALIZAÇÃO - I DA ÁREA COM OCORRÊNCIA DE ROCHAS MANGANESÍFERAS - ARACOIABA E PACAJUS -CE

FORTALEZA

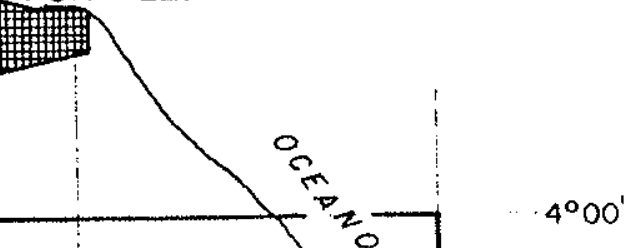

B. $24-X-A-1$

Baturité)

B. $24-X-A-I V$ tapiuna)

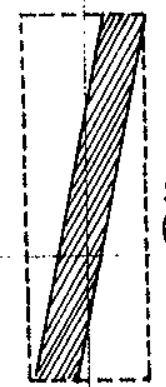

SB. $24-X-A-I 1$

(Beberibe)

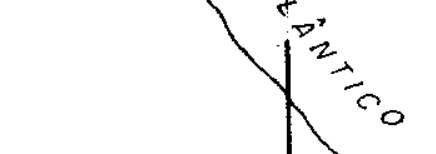

SB. $24-X-A-V$ (Bonhu)
Área de reconhecimento geo lógico

Área de ocorrência de rochas mangonesiferas

Escalo - 1:1.500000 
MAPA DE LOCALIZACÃO II DA ÁREA COM OCORRÊNCIAS DE ROCHAS MANGANESIFERAS DE ARACOIABA E PACAJUS (CE)

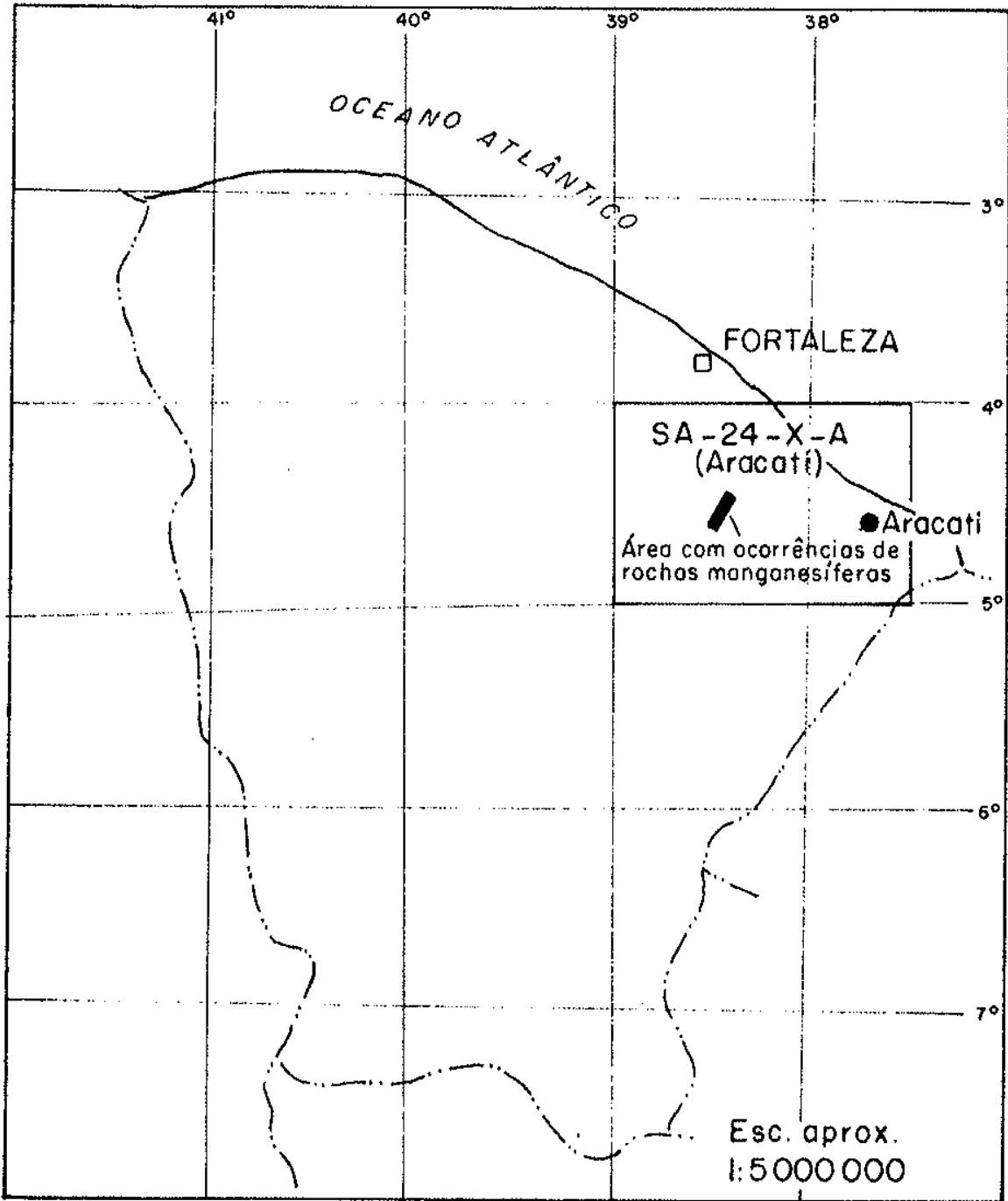

Mapa de localização(2) da ārea de Manganes de Pacajüs-Aracoiaba na Folha $S A-24-X-A(1 / 250.000$ - DNPM $)$. 
QUADRO I - OCORRENCIAS DE MINERIO DE MANGANESS SEGUNDO MORAES (1973), BRAGA (1977) E CRUZUL (1975)

NO DE ORDEM

$$
1
$$

2

3

4

5

6

7

8

9

10

11

12

13

14

15

16

1.7

18

19

$20 *$

21 *
TOPON IMIA

Sítio Casé (Aldeia)

Curral Velho

Lagoa da Pedra

Fiūza (Morros)

Serragem

Canafístula

Lagoa do Riacho

Lagoa dos Porcos

Bolas

Alto do Urubu

Alto Preto

Alto das Madeiras

Alto do Pagão

Açudinho

Alto do Barrigudo

Sítio Lagoa Bonita

Sítio Açude

Deserto

Baixa do Miguel

Alto do Veado

Alto do Gavião
DISTRITO E MUNICIPIO

Pacajūs -Pacajūs

Chorozinho-Pacajūs

Chorozinho-Pacajüs

Chorozinho-Pacajūs

Curupira -Aracoiaba

Curupira -Aracoiaba

Curupira -Aracoiaba

Curupira -Aracoiaba

Curupira -Aracoiaba

Curupira -Aracoiaba

Curupira -Aracoiaba

Curupira -Aracoiaba

Curupira -Aracoiaba

Curupira -Aracoiaba

Curupira -Aracoiaba

Curupira -Aracoiaba

Curupira -Aracoiaba

Curupira -Aracoiaba

Curupira -Aracoiaba

Curupira -Aracoiaba

Curupira -Aracoiaba

* Não estão localizadas no Mapa de Situação. 


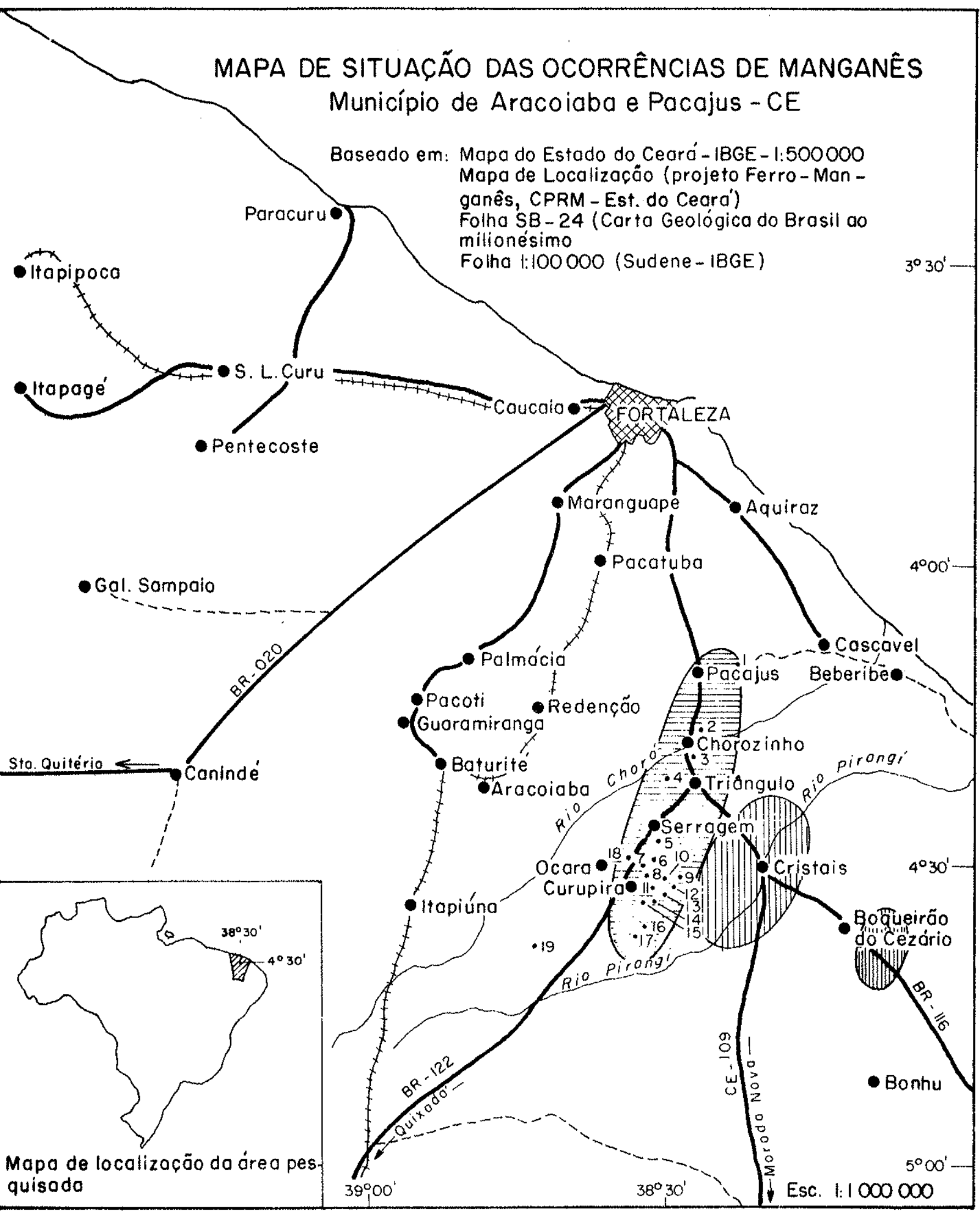

LEGENDA
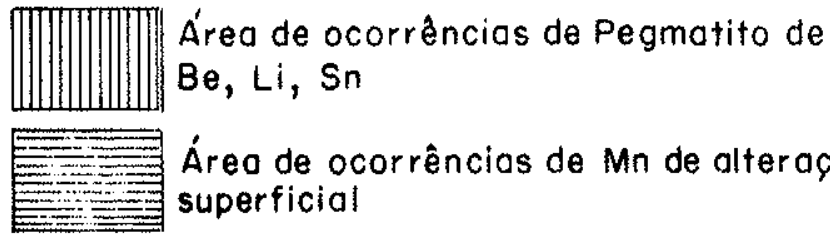

Áreo de ocorrêncios de Mn de alteraçóo superficial

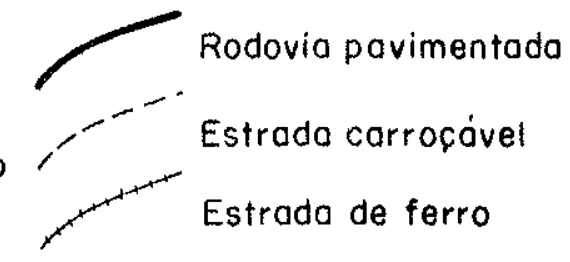

- Ocorrência de manganés

- 5 Ocorrência de Serragem (Mn)

-7 Ocorrência de Lagoa do Riacho

- Sede de municipio

$(M n)$ Rio 
verificar o nümero de ordem no Quadro I (pāg. 7) e no Mapa de Situação (pāg. 8). Os depósitos de Serragem e Lagoa do Riacho estão simbolizados pelos nümeros 5 e 7 , respectivamente.

o acesso à Serragem é feito, em estrada asfaltada, a partir de Fortaleza, pela BR-116 até o Triângulo de Quixadá (74 km) . Daỉ até Serragem, pela BR-122, rumo a Quixadá, percorrem-se $12 \mathrm{~km}$.

O acesso a Lagoa do Riacho é feito a partir de Serragem (rumo a Quixadā), pela BR-122: Percorridos $5,7 \mathrm{~km}$ toma-se a estrada carrocável à esquerda. Até o povoado de Lagoa do Riacho percorrem-se $2,5 \mathrm{~km}$. Daĩ, toma-se a direção para Leste até a localidade de Mata de Vaca, percorrendo-se $2,3 \mathrm{~km}$.

As outras ocorrências são atingidas por estradas carroçāveis bem conservadas durante a estação seca.

\section{2 - ASPECTOS FISIOGRAFICOS}

\section{2 .1 - GEOMORFOLOGIA}

$\mathrm{Na}$ região que corresponde à ārea estudada são conhecidas 5 (cinco) "Superficies" ou tipos de relevo, que correspondem ao mesmo número de níveis ou estágios de erosão: superfície de Tabuleiros, Superfície sertaneja, Superfície de suaves ondulações, Superfície de Elevações de Pequeno porte e superfície de Elevações de Médio Porte.

As Superficies de Tabuleiros (Fig. 1, mod. A) correspondem a superfícies aplainadas de cobertura cenozóica, cuja formação data do Pleistoceno Inferior (MABESOONE et al.,1975). Possui altitude variando de 30 atë $80 \mathrm{~m}$.

Quase ao mesmo nivel do topo da superfície anterior, se forma o extenso pediplano da ärea de rochas cristalinas(BRA- 


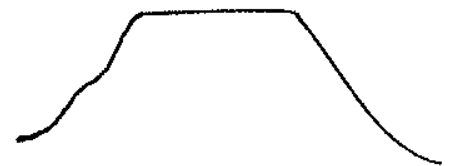

Modelado - A

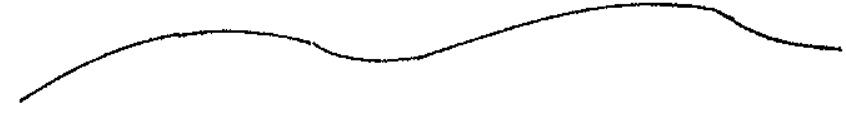

Modelado - B

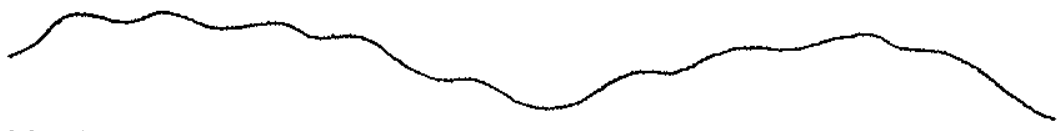

Modelodo-C

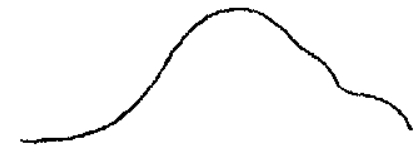

Modelado - D

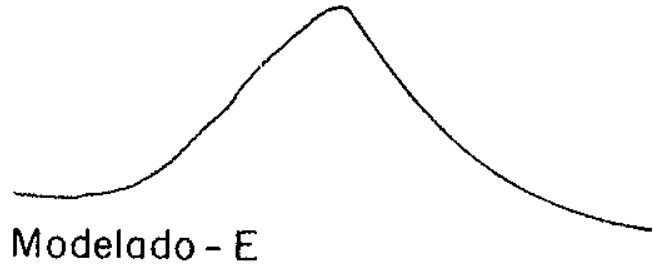

Modelado - E

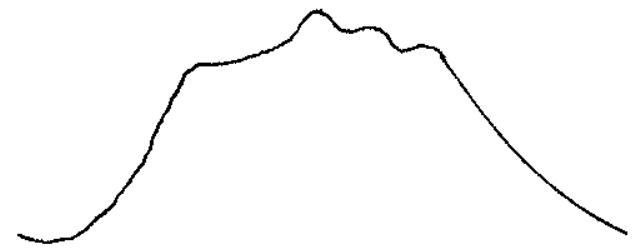

Modelado $-F$

Figura 1 - Feições geomorfológicas da ārea de ocorrências de manganês de Aracoiaba-Pacajūs (CE).

Modelado A - Superfície de Tabuleiros (30 a $30 \mathrm{~m}$ de altitude)

Model.ado B - Superfície de Suaves Ondulações (100 a $115 \mathrm{~m}$ de altitude)

Modelado C - Superfície Sertaneja (80 a $110 \mathrm{~m}$ de altitude)

Modelado D - Superfície de Elevações de Pequeno Porte (130 a $150 \mathrm{~m}$ de altitude)

Modelado E - Superfície de Elevações de Médio Porte, correspondente aos quartzitos ( 160 a $380 \mathrm{~m}$ de altitude)

Modelado F - Superfície de Elevações de Médio Porte, correspondente aos gnaisses (160 a $380 \mathrm{~m}$ de altitude). 
GA, 1977), que foi denominada de superfície sertaneja por MABESOONE et al., (Op.Cit.) e corresponde à superfície Velhas de KING (1956); essa superficie (Fig. 1, mod. C) corresponde simultaneamente ao nivel de abrasão de rochas cristalinas e ao nivel de deposição de areias cenozóicas (ANDRADE et al., 1965). Sua altitude varia de 80 a $110 \mathrm{~m}$.

As superfícies de suaves ondulações (Fig. 1, mod. B), constituídas de cangas manganesiferas ou gnaisses, possuem altitude que variam de 100 a $115 \mathrm{~m}$. Os testemunhos destas superficies representam comumente pequenas ocorrências de manganês.

As Superfícies de Elevações de Pequeno Porte (Fig. 1, mod. D) rompem a homogeneidade da superficie sertaneja, com altitudes entre 130 e $150 \mathrm{~m}$ e são modeladas por gnaisses. Um exemplo típico é a pedreira do serrote pelado, localizado $1 \mathrm{~km}$ ao sul do serrote curupira.

As Superficies de Elevações de Médio porte (Fig. I, mod. E e F) possuem feições marcantes na área; são resíduos de gnaisses e quartzitos que modelam morros e serrotes cujas altitudes variam de 160 a $380 \mathrm{~m}$. São exemplos típicos desta superfície os serrotes de Curupira $(386 \mathrm{~m})$ e Ocara $(270 \mathrm{~m}$ ); (Fotos 1 e 2).

A região de Serragem, distrito de Curupira(Aracoiaba) corresponde precisamente à zona de transição da superfície de Tabuleiros para a superfície sertaneja, dificultando sua distinção pelas altitudes.

\section{$2.2 .2-$ CLIMA}

A área de ocorrência de manganês possui variação de pluviosidade anual entre $1.100 \mathrm{~mm}$ (Pacajūs) e $700 \mathrm{~mm}$ (Serragem), conforme observado no Mapa de Isoietas (päg.14).

Chove principalmente de janeiro a junho, representan- 


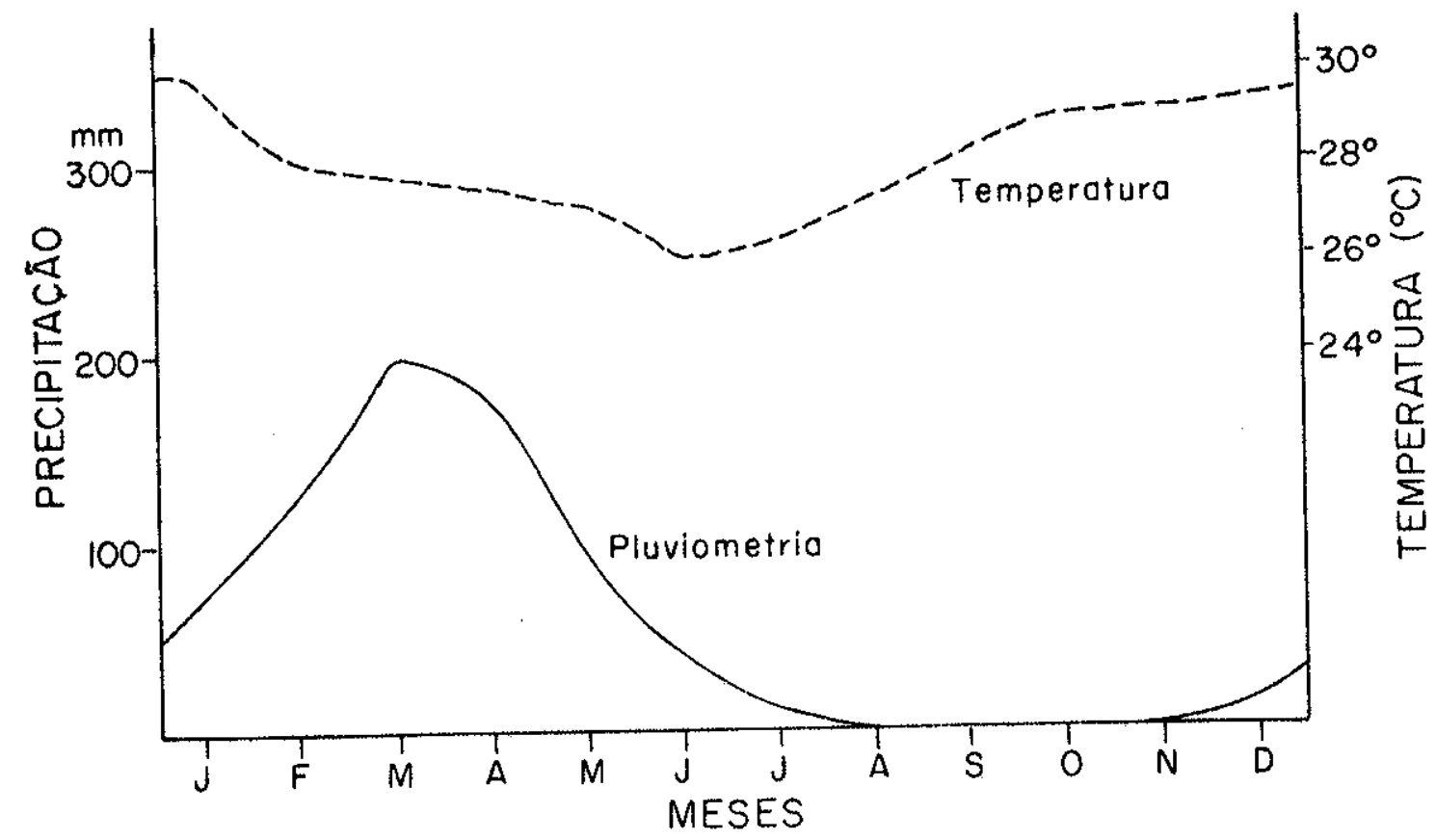

Figura 2 - Varjação de pluviometria (1912-1966) e temperatura (1964-1968) - médias mensais.

Fonte: Inventārio Hidrogeológico do Nordeste, Folha No 10

- Jaguaribe NE-Estação de Morada Nova (MONOEL FILHO, 1971) 


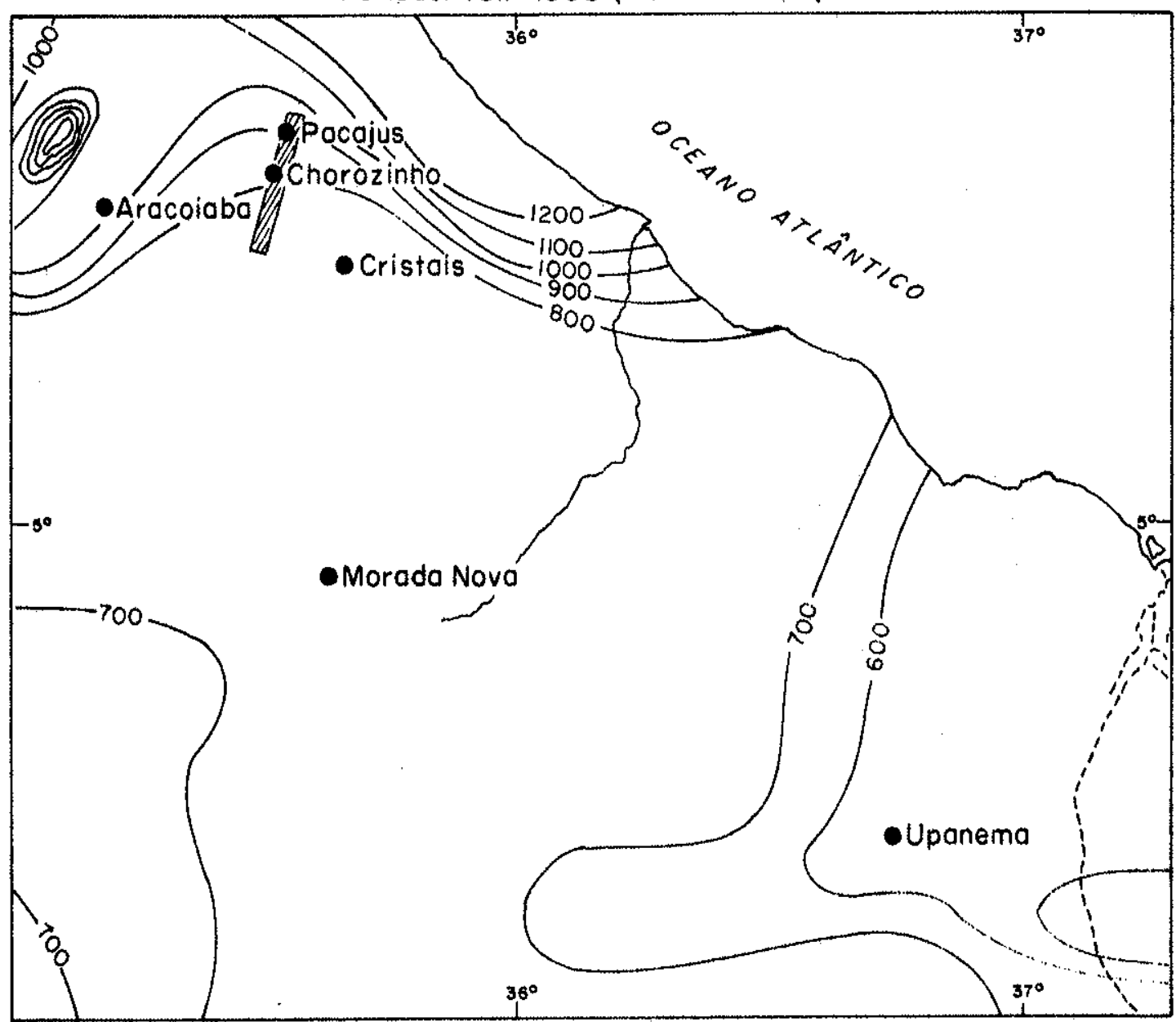

Reproduzido a partir do mapa apresentado no inventário hidrogeológlco do nordes te, Folha no 10 (1971), subtraída a drenagem (MANUEL. FILHO, 1971)

\section{LEGENDA}

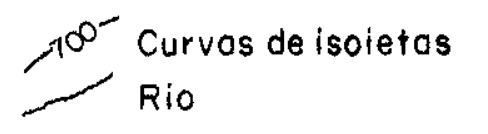

Esc. oprox, 1:170000
- Cidade, povoodo Área de ocorrência de manganes 
do aproximadamente $90 \%$ da mëdia anual. A pluviosidade dos meses de março e abril representa $46 \%$ da precipitação mēdia anual (Fig. 2). Há anos em que as chuvas são escassas, caindo a pluviosidade até $140 \mathrm{~mm} /$ ano (MANOEL FILHO, 1971).

O sistema de chuvas, caracterizado anteriormente, engloba duas estações nitidamente diferentes: a estação chuvosa e a estação seca, denominadas na região de inverno e verão respectivamente.

A temperatura média anual ē $27,3^{\circ} \mathrm{C}$, com mëdia mäxima de $33,9^{\circ} \mathrm{C}$ e méđia mínima de $22,0^{\circ} \mathrm{C}$. No "inverno", a umidade relativa diária varia entre 70 e $75 \%$; diminui para $55 \%$ no verão.

Os dados climāticos acima referidos se enquadram nos critērios estabelecidos para identificação de clima semi-ārido para toda a região.

Os meses de maio a dezembro são propicios para trabalho de campo, tendo em vista que as precipitações de chuvas são poucas ou quase nulas.

\section{2 .3 - VEGETAÇAO E SOLO}

Distinguem-se na região 3 (três) tipos de vegetação: A caatinga seca arborizada e arbustiva, a caatinga úmida arborizada e a caatinga arbustiva. Esta última tem árvores de pequeno porte $(2$ a $5 \mathrm{~m})$, ao contrário das duas primeiras que têm árvores de porte médio (5 a $15 \mathrm{~m}$ ).

A caatinga arborizada seca e arbustiva se desenvolve em altitudes de $250 \mathrm{~m}$ a $350 \mathrm{~m}$, com altura de 5 a $8 \mathrm{~m}$, onde a pluviosidade se situa no intervalo de 800 a $1.000 \mathrm{~mm} / \mathrm{ano}$ (GUICHARD, 1970). São típicas as seguintes ärvores: 
Marmeleiro

Caesalpina Pyramidalis

Leguminosa

Angico Piptadena Macrocarpa

Maniçoba

Euforbiācea

A caatinga arborizada úmida se caracteriza por árvores de 5 a $15 \mathrm{~m}$ de altura,com desenvolvimento em região de pluviosidade variävel entre 1.000 e $1.300 \mathrm{~mm} / \mathrm{ano}$. Ela é mais abundante na região de pacajús. São típicas desta vegetação as seguintes ārvores:

Cajueiro

Mangueira

Carnauba
Anacardium Occidentale Mangifera Indica

Copenicia Cerifera
Anacardiācea

Palmácea

A caatinga arbustiva, de ārvores de pequeno porte, se caracteriza por ärvores de tronco fino de 10 a $30 \mathrm{~cm}$ de diâmetro e 2 a $5 \mathrm{~m}$ de altura; desenvolve-se nos pediplanos em pequenas elevações, onde se encontram as ocorrências de manganês. são típicas desta vegetação as seguintes ärvores:

Timbaúba

Marmeleiro

Croton Hemiargyreus

Euforbiācea

Catanduba

Malícia

Jitirana

Nota-se que todos os tabuleiros, que anteriormente possuiam a vegetação arbustiva natural, estão atualmente reflorestados por cajueiros (Foto 1 ).

$\mathrm{Na}$ região distinguem-se dois tipos de solos: Os solos que se desenvolvem sobre o arenito e os solos que se desenvolvem sobre os gnaisses. O primeiro tem um aspecto ferralitico vermelho, recoberto geralmente por uma camada de areia branca (GUICHARD, Op.Cit.) e recobrindo os modelados A e B (Fig. 1). Os solos sobre gnaisses se desenvolvem em modelados $C$ e são pouco espessos $(10 \mathrm{~cm})$. 


\subsection{4 - REDE HIDROGRAFICA}

A rede hidrográfica da região ë independente da grande bacia do rio Jaguaribe. A ärea é banhada por dois pequenos rios intermitentes, de direção SW-NE: Os rios choró e Pirangi, que passam pelos povoados de Chorozinho e de Cristais respectivamente, e desembocam diretamente no mar.

os alinhamentos dos riachos estão diretamente relacionados a fraturas secundārias resultantes da formação de grande falha que corta a região (Falha "Senador Pompeu").

No pediplano e nos terrenos metamōrficos, a declividade dos rios se aproxima do perfil de equilibrio, onde formam vales abertos em grandes planícies e baixos interflúvios.

Geralmente os rios correm sobre os modelados $A$ e B, desenhados na Figura 1 .

As ocorrências de manganês de Serragem e Lagoa do Riacho se encontram em zona mesopotâmica, dentro da bacia do rio Pirangi e vizinhas ao interflúvio que separam os rios acima referidos.

\section{3 - Histórico DA PROSPECÇO DA AREA}

A sequência de fatos, ora relatados, foi comunicada verbalmente por João Lopes da Silva (1978), prospector do Departamento de Minas do Estado do Ceará.

Em 1951, Basilio Neto, comerciante local com escritório à rua José Avelino em Fortaleza (CE), era concessionário de uma área de ocorrência de minério em Fiüza, em Chorozinho no município de Pacajús. João Lopes da Silva, prospector oriundo das regiões de pegmatito dos Estados da Paraíba e Rio Grande do Norte, encontrou amostras de minerais no escritörio de Basilio 
Neto e as identificou como minérios de manganês. Fez, então, um reconhecimento da área de onde as amostras tinham sido coletadas, encontrando pequenas ocorrências na região de Pacajús.Numa etapa posterior de trabalho encontrou depósitos alterados que se estendem atē a região de Curupira, no município de Aracoiaba.

Ainda em 1951, João Lopes da Silva iniciou trabalhos de prospecção em Serragem (Curupira), tendo em vista que os depósitos de Chorozinho jä estavam sendo prospectados. Para isso, organizou a firma Ceará Manganês Ltda. em sociedade com Jorge Cordeiro, funcionärio do CREA-Fortaleza e Nataniel Brito, curioso em Mineração.

Os trabalhos preliminares foram executados com grande dificuldade e de maneira precāria, entre 1951 e 1957. Por este tempo, a Mineração "Caribe", empresa internacional ligada ao Grupo Rockfeller, se interessou pela ärea e se dispôs a continuar o trabalho, de comum acordo com a Ceará Manganês Ltda. Foram executadas sondagens com trados rotativos e escavações de trincheiras e poços. A malha variava de um lugar a outro, de 20 a $50 \mathrm{~m}$ de distância entre os poços. A profundidade máxima dos furos de trado era de $20 \mathrm{~m}$.

Posteriormente foram contratados os serviços da Companhia T. Janer, que, empregando sondas rotativas, perfurou poços atë $60 \mathrm{~m}$ de profundidade.

Em 1958, a Mineração Caribe implantou um pequeno laboratório químico de campo para pronta análise do material coletado. Até o momento, os resultados deste imenso trabalho não foram publicados ou comunicados de alguma maneira.

Com o afastamento da Mineração Caribe, as pesquisas permaneceram paralisadas por 11 anos (Quadro no 2).

Em 1970, os trabalhos foram recomeçados pela Urandi Mineração com reconhecimento de campo de todos os depósitos.

Em 1973, foram reiniciadas as pesquisas de campo pela Companhia Siderūrgica Cruzeiro do sul (Cruzul), subsidiária 
da Urandi Mineração. Foram feitos novos furos de sonda e escavados outros poços e trincheiras. Muitas escavações ainda permaneciam como testemunhos de prospeç̧ões anteriores. O Departamento de Minas do Estado do Ceará colaborou com esta última fase, emprestando sondas rotativas e operadores auxiliares.

Ém 1975, a mineração apresentou ao DNPM os relatórios de pesquisa referentes a diversas áreas de concessão (CRUZUL, 1975).

QUADRO NO 2

RESUMO DA HISTORIA DA PROSPECÇÃO DA AREA DE OCORRENCIA DE MANGANES DE PACAJUS-ARACOAIBA (CE)

\begin{tabular}{|c|c|}
\hline DATAS & EVENTOS \\
\hline 1951 & Descoberta das ocorrências de manganês \\
\hline $1951-1957$ & $\begin{array}{l}\text { Prospecções desenvolvidas pela mineração } \\
\text { Cearä Manganês Ltđa. }\end{array}$ \\
\hline $1957-1.958$ & $\begin{array}{l}\text { Prospecções desenvolvidas pela Mineração } \\
\text { Caribe }\end{array}$ \\
\hline $1959-1970$ & Paralização de todos os trabalhos \\
\hline $1973-1974$ & $\begin{array}{l}\text { Prospecções desenvolvidas pela Companhia } \\
\text { Siderürgica Cruzeiro do Sul }\end{array}$ \\
\hline 1975 & $\begin{array}{l}\text { Apresentação de Relatórios ao DNPM pela } \\
\text { Mineração Companhia Siderūrgica Cruzeiro } \\
\text { do Sul }\end{array}$ \\
\hline
\end{tabular}


4 - REVISÃO BIBLIOGRAFICA

COELHO (1957) cita ocorrências de manganês nos locais de Fiúza (Pacajús) e Serrote, Serragem, Ludgero, Canafistula e Lagoa dos Porcos (Aracoiaba); encontram-se como lentes em quartzitos e trata-se de "horizontes manganesiferos da série ceará, provenientes de filitos intercalados em quartzitos", que, às vezes, por erosão, formam "depósitos aluviais".

MANOEL FILHO (1971) faz uma anālise pormenorizada do clima e um esboço da geologia regional. Estabelece para a área a seguinte sequência estratigráfica:

Dunas

Arenitos (Formação Barreira)

Micaxistos (Formação Seriđō)

Quartzitos dominantes (Formação Equador)

Meta-arcósios, gnaisses bandeados e

facoidais (Grupo Caicó)

A ārea de manganês situa-se dentro da zona de micaxisto da Formação Seridó, conforme MANOEL FILHO (Op.Cit.).

SANTOS et al. (1972) compila o Mapa Geológico do Estado do Ceará, em escala 1/500.000, no qual os depösitos de manganês estão localizados na sērie ceará.

MORAES (1973) faz um levantamento de ocorrências de todos os minerais do Esstado do Ceará, onde cita as ocorrências da província de Aracoiaba-Pacajūs, como depösitos importantes para estudo.

MORAES (1974) faz uma descrição sumária de todas as ocorrências de manganês do Estado do ceará. o protominério de manganês de Aracoiaba-Pacajús é descrito como um granada-quartzito, constituido de $50 \%$ de quartzo, $40 \%$ de granada e $10 \%$ de material mangano-ferruginoso. 


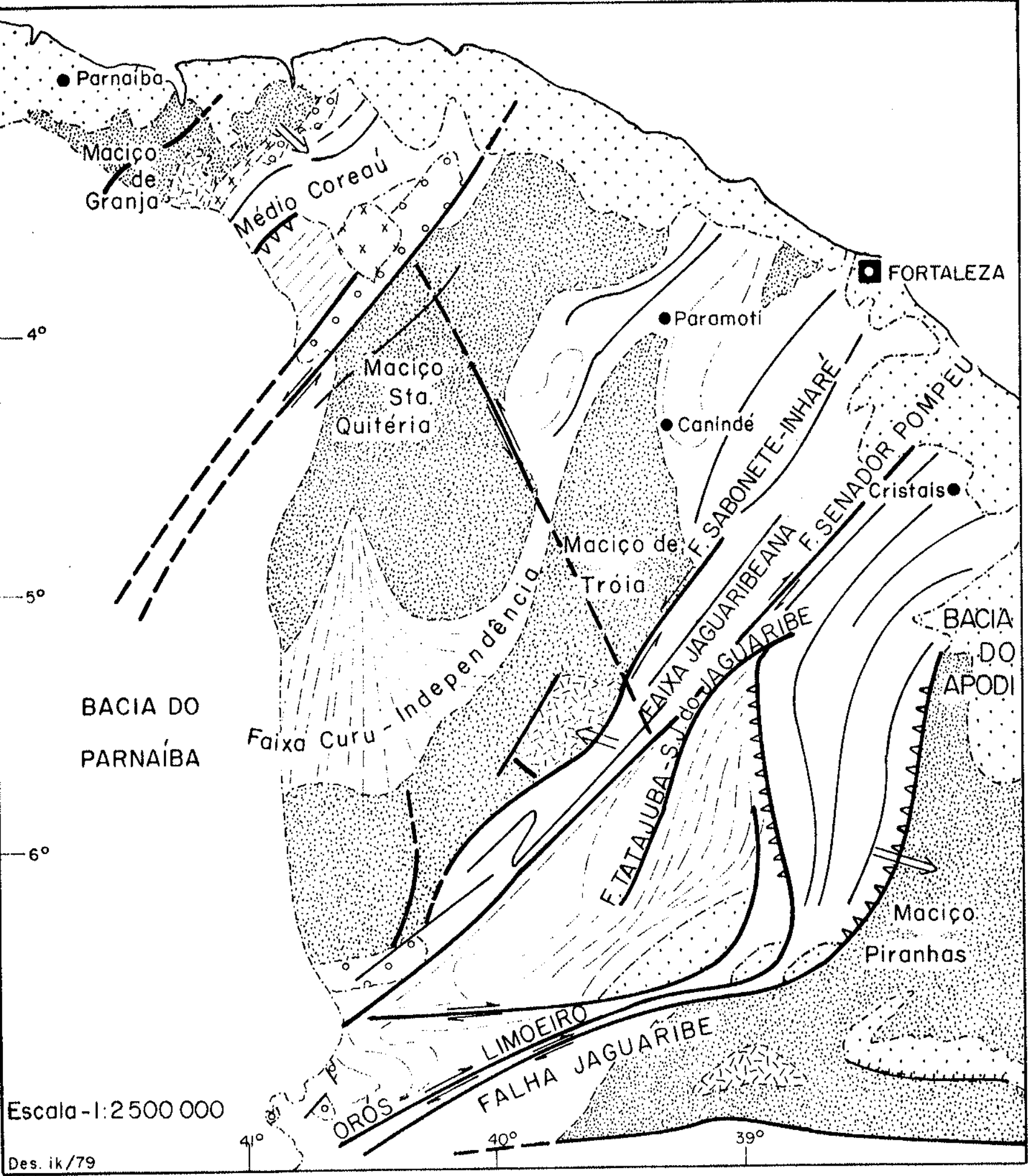

LEGENDA
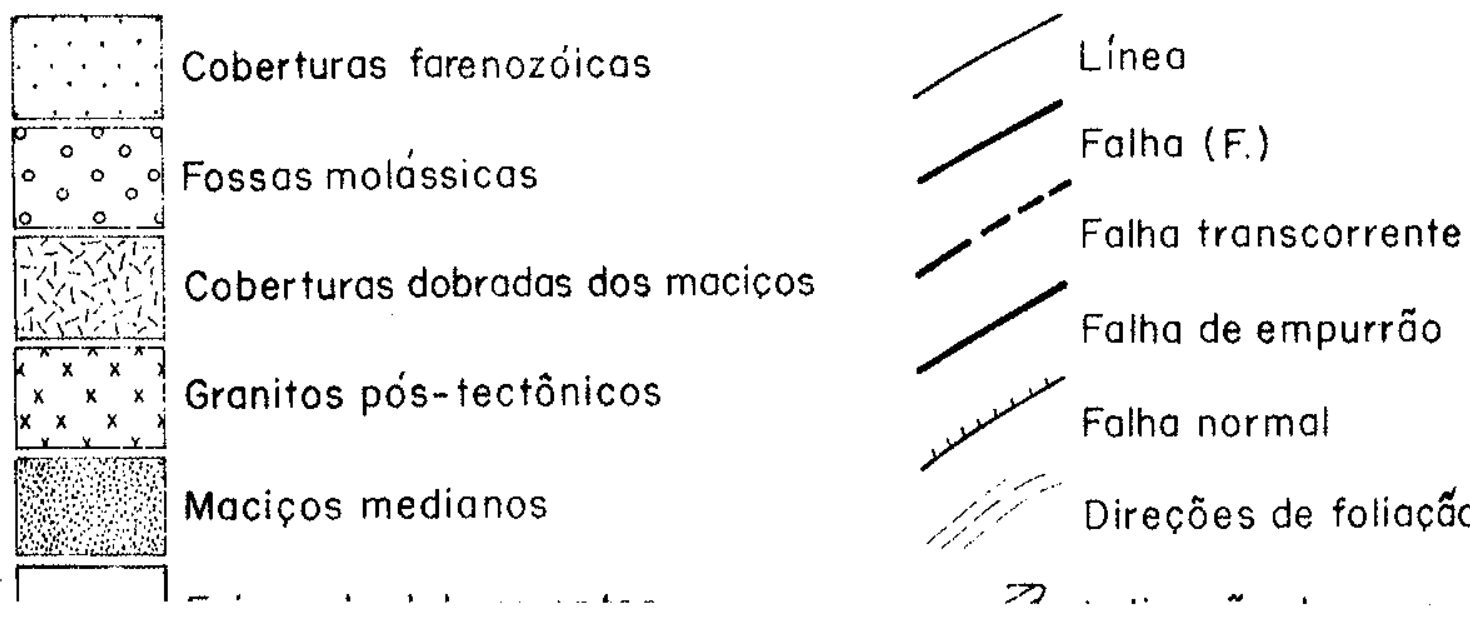

Direções de foliaçấo 
Apresenta algumas anālises químicas onde o teor de $\mathrm{Mn}$ oscila entre 16 a $43 \%$ (Tabela no 17).

MORAES (1974) sugere a existência de värias lentes paralelas de protominērio de manganês, intercaladas no migmatito regional, pertencente ao Pré-Cambriano Inferior.

DANTAS (1974) situa a ārea de ocorrências de manganês de Aracoiaba-Pacajús na série ceará. Geotectonicamente a ārea é incluída nos "Dobramentos caririanos" hoje conhecidos também como "Faixas de Dobramentos do Nordeste".

BRITO NEVES (1975) posiciona tectonicamente as ocorrências de manganês na faixa jaguaribeana, conforme Mapa Geotectônico na pägina 21. Esta faixa se situa dentro do ciclo transamazônico sendo remobilizada no ciclo brasiliano. Na estratigrafia da faixa jaguaribeana, distinguem-se 4 (quatro) sequências: 1 - Substrato granito-gnaisse, 2 - Seqụ̂ncia basal metapsamítica, constituida de gnaisses a biotita e hornblenda, gnaisses a duas micas e inümeras intercalações de quartzito-gnaisse e quartzitos com lentes carbonáticas no topo; de maneira restrita, aparecem intercalações de anfibölio-xistos; o metamorfismo é, em geral, de fácies anfibolito, 3 - Sequência terrígena superior, formada por sedimentação argilo-arenosa, constituída de quartzitos micáceos, niveis carbonáticos e metabasitos e 4 - Depósitos ortomolässicos da bacia de Cococi de origem pós-geossinclinal.

A Companhia siderūrgica Cruzeiro do Sul -Cruzul (1975), em relatório de pesquisa ao Departamento Nacional da Produção Mineral, classifica o protominério de manganês da região como "Gondito", em correlação com os depōsitos da India. O gondito é descrito com composição de $42 \%$ de espessartita, $39 \%$ de quartzo e 8\% de opacos. Foi formado em metamorfismo de grau mëdio entre a făcies xisto verde e fácies anfibolito. O teor médio de manganês varia entre $27 \%$ e $31 \%$ aproximadamente.

BRAGA et al. (1977) situa as ocorrências de manganês dentro da faixa orogenética tipo "Mobile Belt", relacionada a terrenos metamórficos portadores de silicatos manganesíferos e 


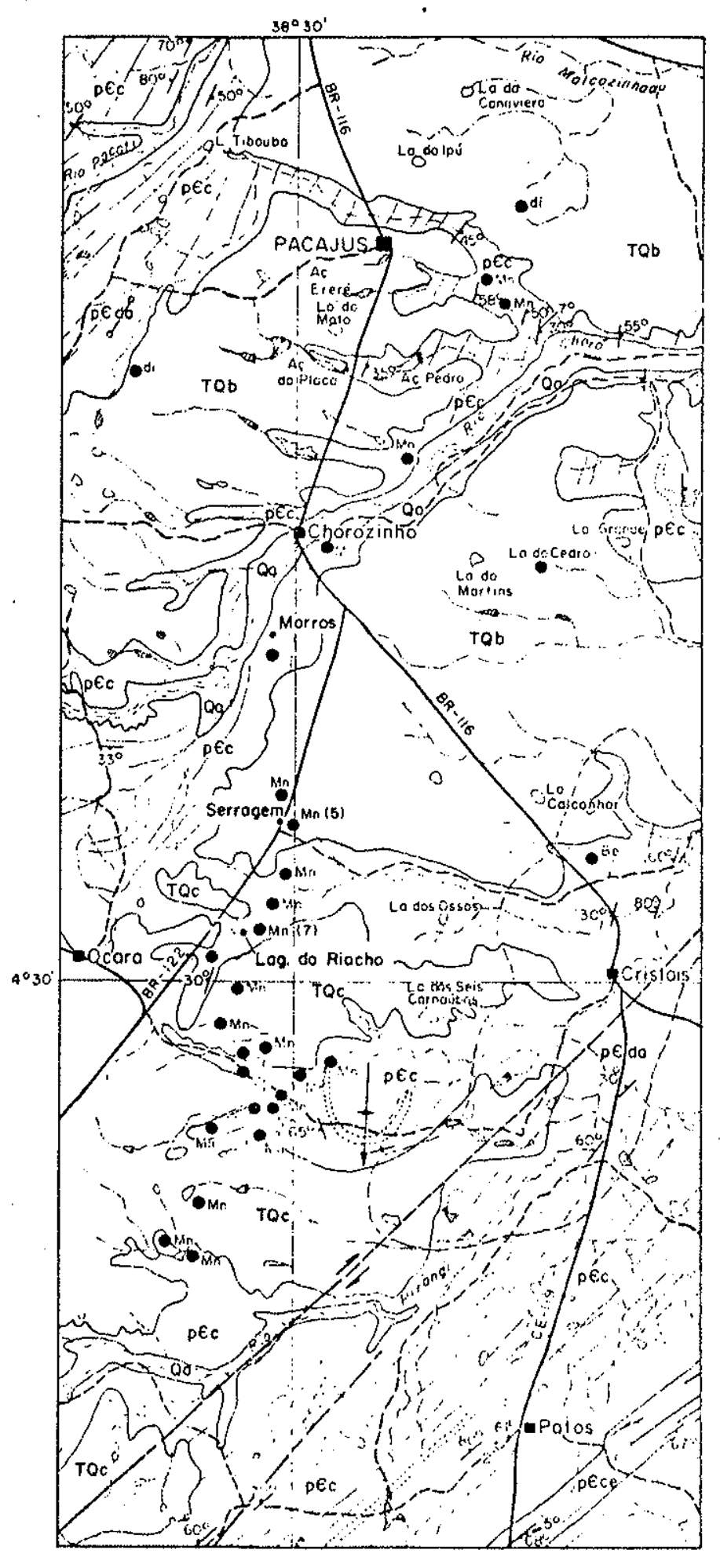

MAPA GEOLÓGICO DA PROVINCIA

MANGANESIFERADE ARACOIABA-PACAJUS(CE)

Extraído do Projeto Fortaleza, Brago(1977)

Folha Aracati-SB-24-X-A

\section{LEGENDA}

CONIENÇŌES GEOLÓGICAS

(Quokernório) Qo aluviōes.

Tercidrio t TOC cobertura colúvio-eluvial

Tercidrio TOb Grupo Barreiros.

Pré-Cambrig Grupo Ceoró

Pré-Cambrị $\left\{\begin{array}{cc}p \in c & \text { Complexo Coicó. } \\ q & \text { quortzito }\end{array}\right.$

peda diques ácidos.

ट八 Contato detinido.

80 Atitude do folioçáo.

$25^{5} 5^{\circ}$ Foliof̧ōo com morcoço de coimento do lineoçóo.

Folha transcorrente de Sen.Pompeu.

Folho encoberta.

" Froturo.

Troços da foliaçáo.

Foliogōo.

Antiforme com coimento.

o Dique.

$\therefore$ Regicio de pegmotito.

CONVENCÓES CARTOGRÁFICAS

Q.10) Rodovio federal.

Con Rodovia estadual.

Estrado corroçóvel.

Rios e riachos temporórios.

Gi... I: Acude.

Logoa.

- Cidade.

- Povoodo.

- Lugarejo

NM NG

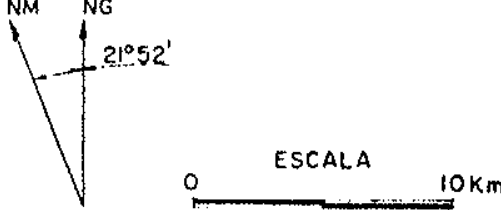


"pobres em quartzitos". Os autores apresentam um mapa geológico em escala 1/250.000, onde são localizadas as ocorrências (pāg. 23). o protominério é constituído de quartzo, rodocrosita e granada. O minērio de manganês é formado principalmente de pirolusita e criptomelano.

BRAGA et al. (Op.Cit.) situa as áreas de manganês no Prë-Cambriano Inferior, representado pelo Complexo Caicö, constituido de gnaisses e quartzitos.

ABREU (1978) cita os depósitos de manganês situados em Cangati (Quixadā) e Aquiraz como originados por alteração pouco pronunciada de rochas com espessartita, cujas análises apresentam teores de $15 \%$ de $\mathrm{SiO}_{2}, 44,9 \%$ de $\mathrm{Mn}, 70,9 \%$ de $\mathrm{MnO}_{2} 2,4 \%$ de $\mathrm{Fe}$ e 0,05 de $\mathrm{P}$. Esta ocorrência jä foi reportada por SOUZA (1939), como pertencente ao município de Baturitē.

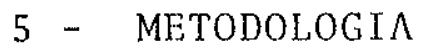

A metodologia utilizada neste trabalho foi dirigida no sentido de posicionar os depósitos de manganês dentro de um contexto geológico. Para isso foram estudadas as rochas encalxantes e suas relações com o protominērio de $\mathrm{Mn}$, a fim de estabelecer as condições de metamorfismo. Além do mais, foi feito um posicionamento estratigráfico, estrutural e geotectônico para todo o conjunto litológico.

Foram estabelecidas as paragêneses do protominērio de sua parte oxidada. A paragênese primária sedimentar foi inferida a partir de dados experimentais registrados na literatura especializada comparados com os dados conseguidos por meio dos procedimentos relacionados a seguir. 


\section{1 - TRABALHO DE CAMPO}

o trabalho de campo foi realizado em três etapas. Na primeira foi feito um reconhecimento geral de 17 ocorrências da provincia manganesifera de Aracoiaba-Pacajús, com o objetivo principal de selecionar dois depósitos para trabalho pormenorizado. Foram escolhidas as áreas de serragem e Lagoa do Riacho, em virtude de um maior nümero de serviços de exploração, e tendo em vista que todos os depösitos são homogêneos quanto aos fatores geológicos gerais. Ainda nesta etapa, foram coletadas amostras para estudos preliminares.

Com base nos dados colhidos durante o reconhecimento de campo, foi elaborado um plano de pesquisa em que estavam previstos os trabalhos a serem executados na fase posterior de campo.

Na segunda etapa, foi realizada uma coleta de rochas encaixantes e de protominério, de âmbito regional, a fim de possibilitar a determinação da fäcies metamórfica dos depósitos e suas caracteristicas.

Numa texceira etapa foram feitos trabalhos de geologia local, que foi esboçada a partir de descrição e amostragem de furos de sonda e de poços e trincheiras de exploração, remanescentes de trabalhos anteriores historiados no item 3 .

Devido à profundidade das escavações ( 8 a $12 \mathrm{~m}$ ), a amostragem foi feita com auxilio de sarilho e corda. Os poços de Serragem foram amostrados de metro em metro. Os furos de sonda foram amostrados em caixas de testemunho armazenadas em um depósito na localidade de serragem.

De maneira geral, cuidou-se em coletar amostras de protominéxios em vários estágios de alteração. 


\section{2 - DETERMINAÇÃO DE MINERAIS E TEXTURAS}

A presente investigação combina o estudo óptico rotineiro, por observação em lâminas delgadas e em seções polidas, com a análise de pó por raio $x$, em câmara Debye-Scherrer com filme de 114,6 mm, para determinação de minerais, principalmente óxidos de manganês.

Esse mëtodo envolve inicialmente a escolha de amostras que incluam värios tipos de textura e mineralogia para confecção de seções polidas e lâminas. Das seções polidas e das lâminas delgadas são obtidas fotomicrografias no aparelho"ultraphot II", da Zeiss, em chapas rígidas tamanho $9 \times 12 \mathrm{~cm}$. Posteriormente é feito um estudo de textura e mineralogia. Os minerais de identificação duvidosa são extraídos em forma de pó, a partir da seção polida, por meio de broca de dentista com estilete diamantado; os pontos de amostragem são lançados nas fotomicrografias. O pó do mineral é misturado em cola, ressecado e transformado em pequenos filetes ("Biscoito") que são postos na câmara de difração em local apropriado, a fim de ser atingido pelos raios $x$, que se difratam e imprimem curvas (raias) nos filmes dispostos circularmente na própria câmara. Para leitura dos filmes emprega-se o "leitox" tipo Norelco, com precisão de $0,5^{\circ}$. Pelo fichário JCPDS (1971) determinam-se parâmetros que identificam o mineral.Esta identificação é confirmada por ASTM (1965).

Para definir a composição da granada foram utilizados três parâmetros: $\Delta 2 \theta$ (diferença de dois teta), D ( densidade) e $n$ (indice de refração). A diferença de $2 \theta(\Delta 2 \theta)$ foi calculada a partir da cela unitária, obtida a partir do filme de difração de raios $x$, conforme método descrito por AZAROFF et al. (1958). A densidade (D) dos grãos foi obtida atravēs de imersão em licor de clerici, cujo indice de refração foi medido em refratômetro tipo Leintz-Jelly. Posteriormente este indice foi lançado em uma curva de variação de densidade em função do indice de refração (JAHNS, 1939). O indice de refração(n) foi 
obtido com imersão em líquidos padronizados e observados ao microscópio com transmissão de luz de sódio. Os índices de refração dos líquidos utilizados foram verificados no refratômetro tipo Leintz-Jelly.

Os parâmetros assim determinados foram lançados em nomogramas associando $\Delta 2 \theta$ e $n, \Delta 2 \theta$ e $D$ e $n$ e D. A composição molecular mais coerente foi o resultado utilizado neste trabalho. Este método está descrito,em pormenores,por MADUREIRA FILHO (1972) e CAMARGO \& MADUREIFA FILHO (1976).

\section{3 - ANÂLISES QUIMICAS}

Foram utilizados dados de anālises químicas,executadas pela Sociedade Brasileira de Superintendência S/A, com laboratōrios à rua Simimbu, 407 (Rio de Janeiro), em 114 amostras enviadas pela Companhia Siderúrgica Cruzeiro do Sul (1975) para determinação do teor em Mn; e em seis amostras para determinação do teor em $\mathrm{Mn}, \mathrm{Fe}, \mathrm{SiO}_{2}, \mathrm{Al}_{2} \mathrm{O}_{3}$ e P. Estas amostras são referentes a vārias ocorrências.

Foram utilizados também dados de análises em 19 amostras de toda a área encontrada em MORAES (1974), quanto a Mn, $\mathrm{Fe}, \mathrm{SiO}_{2}, \mathrm{P}, \mathrm{S}$ e $\mathrm{H}_{2} \mathrm{O}$.

O laboratório do Departamento de Minas analisou dez amostras com determinação de $\mathrm{Mn}, \mathrm{Fe}, \mathrm{SiO}_{2}, \mathrm{Al}_{2} \mathrm{O}_{3} \mathrm{e} \mathrm{P}$, em rochas referentes a Serragem e Lagoa do Riacho, coletadas na segunda etapa de campo.

o laboratório de química do Departamento de Petrografia e Mineralogia (USP) realizou três anālises em amostras de rocha encaixante a fim de auxiliar na determinação das condições de metamorfismo.

O laboratōrio puriquima, situado à rua da Encarnação, 18 (S.Paulo,SP) realizou análises em seis amostras para determinação de $\mathrm{Pb}, \mathrm{Zn}, \mathrm{Cu}, \mathrm{Ni}$ e Co por meio de espectômetro de ab- 
sorção atômica em aparelho modelo 1250 (Varian Techtron).

Os elementos $\mathrm{Cr}$ e $\mathrm{Sr}$ foram determinados por meio de espectrômetro de Fluorescência de Raios $x$, em aparelho tipo Philips, do Centro de Geocronologia do Instituto de Geociências (USP).

\section{4 - ESTUDO DE FALHAS TRANSCORRENTES}

Foi utilizado o modelo regmático de MOODY \& HILL (1956) e MOODY (1973) para fazer correlações entre falha e mineralização. Embora a teoria se encontre explicitada em loczy et al. (1976), apresenta-se aqui um resumo suficiente para compreensão imediata da nomenclatura usada no texto.

Para os autores acima referidos, um esforço primário compressivo causa dois padrões de falhas transcorrentes de primeira ordem, com ângulo de $30^{\circ}$ em relação à direção de tensão principal compressiva. Apenas um dos padrões se manifesta plenamente (Figs. 3 e 4 ).

Em função do esforço principal surgem falhas transcorrentes subordinadas à falha principal e dobramentos de primeira ordem perpendiculares à direção do esforço principal (Fig. 3, letra b) e dobramentos de segunda ordem formando $15^{\circ} \mathrm{com}$ a falha principal (Fig. 4, letra C).

As falhas transcorrentes de todo o mundo pertencem a dois sistemas primārios de esforço compressivo: 10 - Sistema Tectônico Meridional, com esforço principal de direção N-S (Fig. 5). 28 - Sistema Tectônico Equatorial com esforço principal de direÇão $\mathrm{E}-\mathrm{W}$ (Fig. 6).

o sentido do movimento relativo dos blocos é contrário ao vêrtice do ângulo agudo entre os dobramentos secundärios e a falha transcorrente principal (MOODY, 1973), conforme Figura 7. 


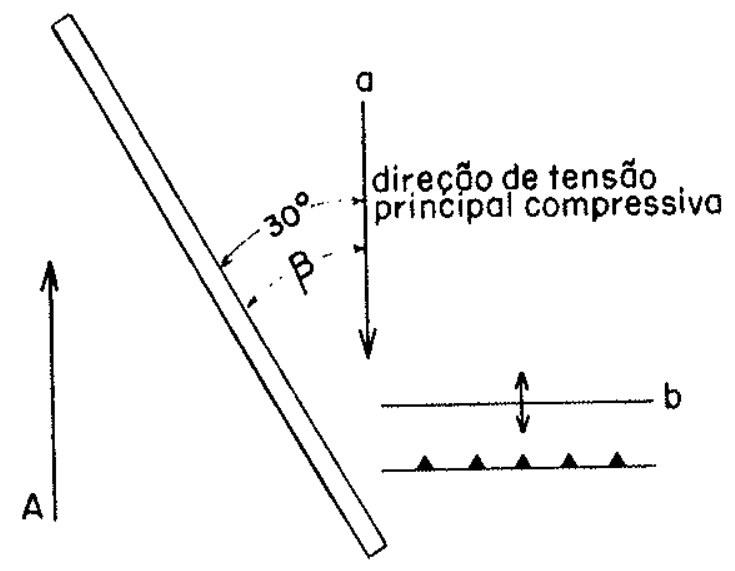

Figura 3 - a) direção prțmāria de tensão principal compressiva

b) direção primāria de dobramento e empurrão

Figura 4 - Deformação de 2a ordem
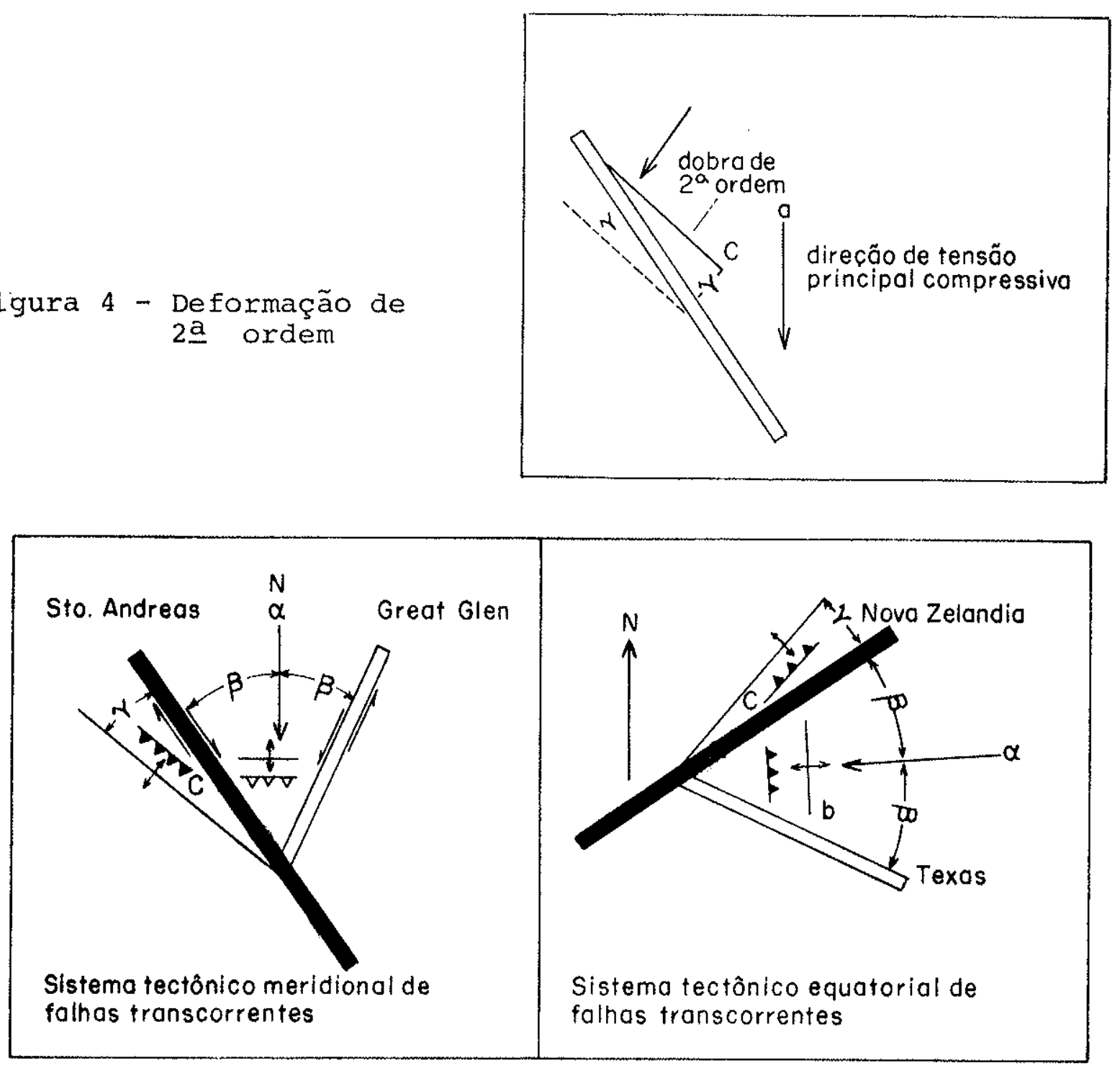

Figuras 5 e 6 - Sistemas Tectônicos de falhas transcorrentes. $\alpha=$ azimute de direção compressiva principal. $\beta=a ̄ n g u-$ 1o de cisalhamento e $\gamma=$ ângulo dos dobramentos secundärios. 
Figura 7 - o vértice do ângulo al tem direção sudoeste, enquanto o Bloco A possui movimento de direção nordeste; Elxo de dobramentos secundários o vêrtice do ângulo a2 tem direção nordeste, enquanto 0 Bloco $B$ possui movimento de direção sudoeste.

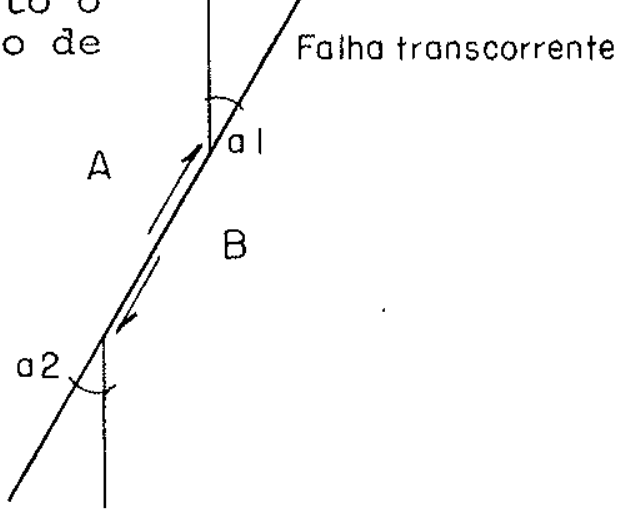

6 - GEOLOGIA REGIONAL

6.1 - CONSIDERAÇÕES SOBRE A TECTONICA REGIONAL

As mineralizações de manganês estão associadas à faixa jaguaribeana (BRITO NEVES, 1975). Neste capitulo, tenta-se relacionar geologicamente as mineralizações às falhas transcorrentes que cortam esta faixa (Vide Mapa Geolögico, päg.23). Para tal intento, aplica-se o modelo de MOODY \& HILL (1956) e MOODY (1973) sobre dados colhidos no campo e na literatura.

As faixas de dobramento do Estado do Ceará estão divididas em blocos tectônicos separados por falhas transcorrentes (KEGEL, 1965 e BRITO NEVES, 1975). A faixa jaguaribeana é cortada pela faixa transcorrente de senador pompeu (N45 E) e pela falha transcorrente Sabonete-Inharé $\left(\mathbb{N} 40^{\circ} \mathrm{E}\right)$ que a separa do maciço de Troia (Vide Mapa Geotectônico, päg. 21).

BRITO NEVES (Op.Cit.) afirma que a falha de senador pompeu é dextrógira. Isto pode ser inferido a partir de observações do sentido do vértice dos ângulos agudos formados por fa- 
Ihas menores com a falha principal, em fotografias aéreas comuns. Sabe-se, pragmaticamente, que o movimento relativo dos blocos tem direção conträria ao vērtice do referido ângulo, conforme mostra a Figura 7. Sendo assim a falha de Senador Pompeu pode ser esquematizada conforme Figura 8 .

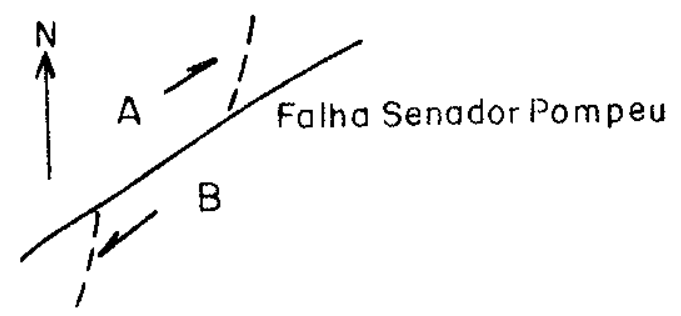

Figura 8

Falha dextrógira de Se nador Pompeu. O sentido do movi mento do bloco B (Bloco direito) é para o observador.

A falha de Senador Pompeu, pelo fato de ser dextrogira e por possuir direção $N 45^{\circ} \mathrm{E}$, se enquadra no sistema Tectônico Equatorial, tipo Nova-Zelândia, ou seja, direita equatorial (Fig. 6, pāg.29). Neste caso seus parâmetros aproximados são: alfa $=82^{\circ}$ (Azimute) e 2 beta $=74^{\circ}$.

No Mapa Estrutural (pāg. 32) pode ser observado um sistema de dobramentos primários perpendiculares à direção do esforço de compressão principal, na região de Bonhu e que pode estar associado à falha de Senador Pompeu. No mesmo mapa, a leste de Curupira são observados dobramentos formando $15^{\circ}$ (gama) com a falha de Senador Pompeu; estes são considerados dobramentos de 2a ordem do Sistema Equatorial tipo Nova-Zelância (Fig. 9).

Superimposto ao sistema Equatorial de falhas transcorrentes, existe o sistema Meridional representado na ärea pela falha Sabonete-Inharé, que delimita o maciço de Tróia em relação à faixa jaguaribeana. Pelo mesmo critério aplicado ante- 


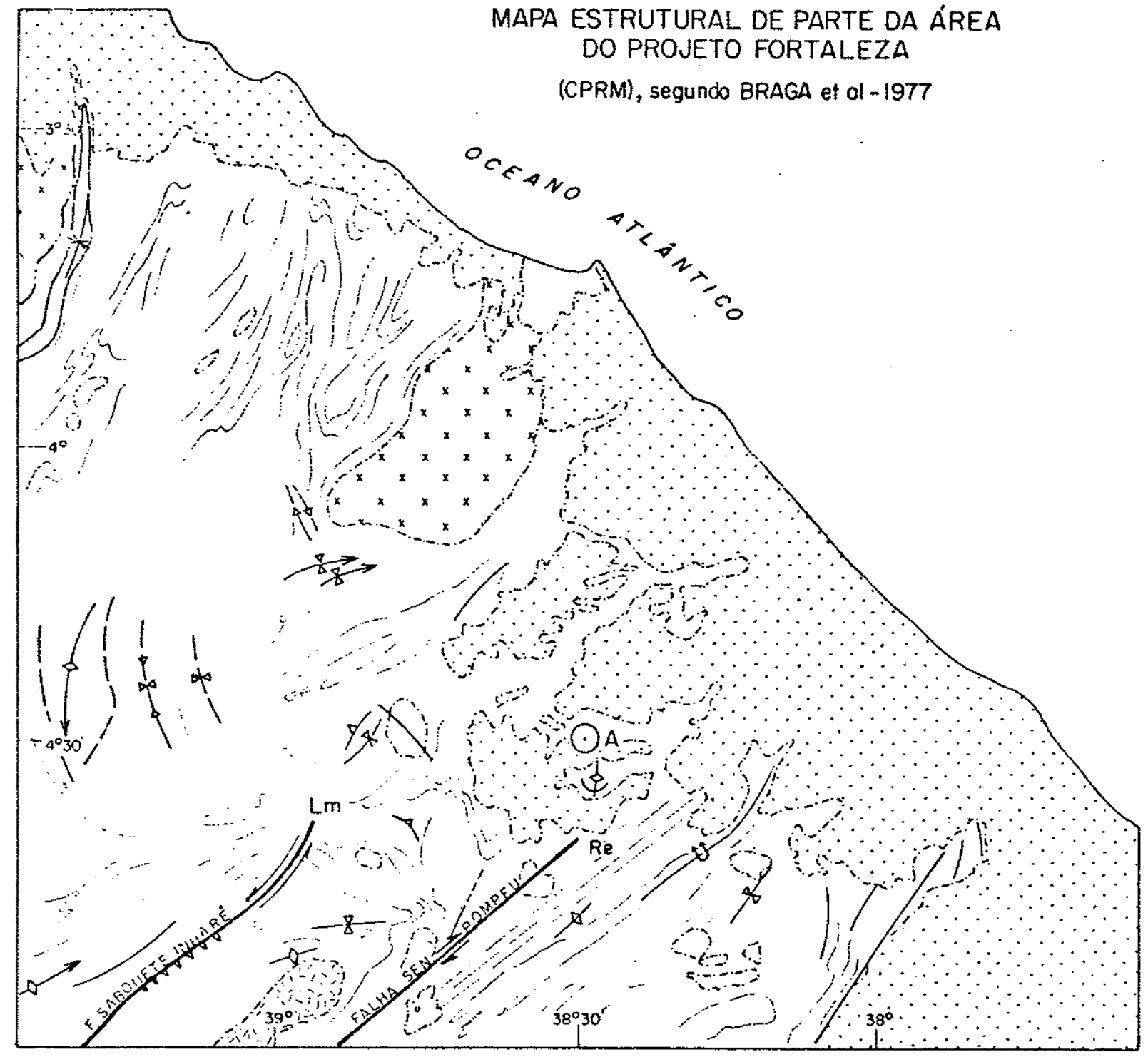

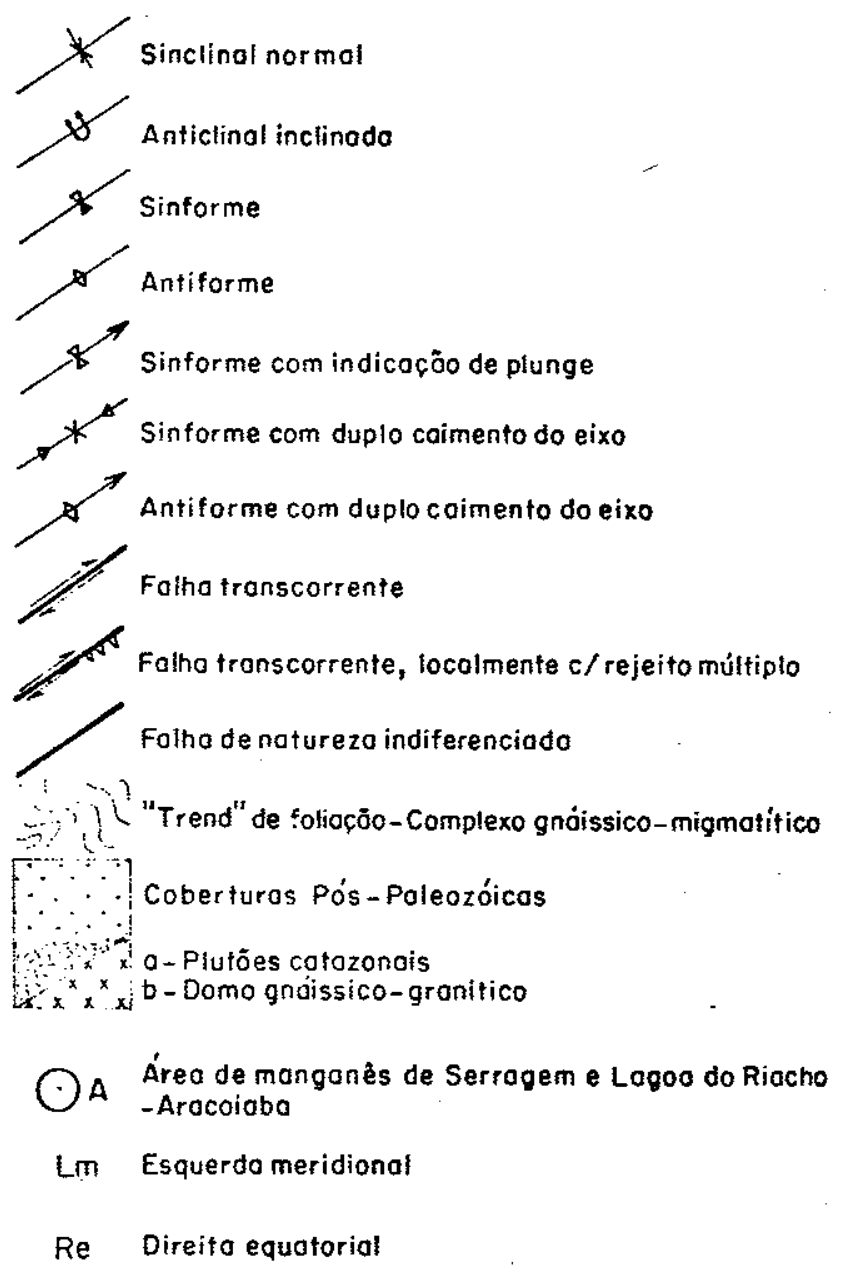

Escalo 1:1.250.000 
riormente, infere-se que esta falha é levögira, e como tal, pertencente à esquerda meridional, tipo Great Glen, conforme Figura 5 .

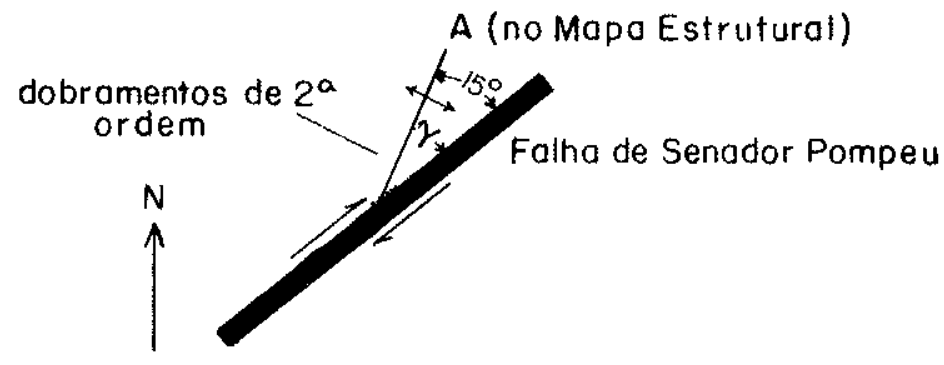

Figura 9 - Dobramento de 2 a ordem formando $15^{\circ} \mathrm{com}$ a falha trans corrente de senador Pompeu $\left(\mathrm{N} 45^{\circ} \mathrm{E}\right)$.

Estas duas falhas (Senador Pompeu e Sabonete-Inharé) delimitam um bloco tectônico que foi movimentado em épocas diferentes, já que o sistema equatorial, comumente, é mais antigo que o sistema meridional (MOODY, Op.Cit.). Como consequência, os dobramentos sinformes e antiformes têm atualmente uma orientação que variam desde NE-SW ao sul da ärea, até NW-SE ao norte, devidos aos movimentos diferenciais entre duas falhas (Mapa Estrutural,päg. 32). Os serrotes de Ocara e Curupira sofreram os efeitos conjuntos destas duas falhas.

Em resumo, os depósitos de manganês da região de Bonhu estão associados tectonicamente aos dobramentos primários, perpendiculares ao esforço principal de que resultou a falha de senador pompeu. Ao contrário, os depōsitos de serragem (Curupira) estão associados aos dobramentos de $2 \stackrel{\text { a }}{\text { ordem }}$ ligados a mesma falha. 


\section{2 - CONSIDERAÇÕES SOBRE A GEOCRONOLOGJA DA REgIÃO}

Na faixa jaguaribeana existem värias determinações radiométricas pelos métodos $\mathrm{Rb}-\mathrm{Sr}$ e $\mathrm{K}$-Ar (Tabela 1 ). A partir dos dados de Rb-Sr em rocha total, foram construídas duas isócronas: uma delas, a partir dos migmatitos da região de Quixadá, que se inclui no mesmo bloco tectônico da região de Serragem (KAWASHITA et al., 1976, Fig. 10); a outra, a partir de gnaisses e migmatitos coletados entre Iguatu e Tróia (BRITO NEVES, 1975, Fig. 11). Em ambos os casos trata-se de isōcronas de referência com idade aproximada de $2.000 \mathrm{~m} . \mathrm{a}$., e razões iniciais respectivas de 0,707 e 0,703. Indicam, portanto, a existência de rochas do ciclo transamazônico na faixa jaguaribeana, no bloco tectônico compreendido entre as falhas transcorrentes de Senador Pompeu e Sabonete-Inharé no maciço mediano de Tróia. Nas mesmas áreas em que foram obtidas as amostras transamazōnicas por KAWASHITA et al. (1976) e BRITO NEVES.(1975), outros dados $\mathrm{Rb}-\mathrm{Sr}$ em rocha total evidenciaram a existência de episödios formadores de rochas no ciclo brasiliano. Nas Figuras 10 e 11 aparecem claramente as tendências de vários pontos analiticos alinharem-se segundo isócronas de referência de 570 e de $550 \mathrm{m.a}$. respectivamente.

Segundo BRITO NEVES (1975), a isócrona de referência de $550 \mathrm{~m} . \mathrm{a}$. por ele traçada (Fig. 11) enquadra um evento termo-tectônico pós-orogênico, caracterizado por instabilidade ao longo de toda a falha de senador Pompeu. Na parte nordeste da falha hä ascenção de fluidos hidrotermais formando pegmatitos homogêneos e heterogênos; na parte central, há formação de dique de natureza monzonitica, dioritica e granodioritica (BRAGA, 1977) e na parte sudoeste ocorrem movimentos verticais que condicionam o surgimento da fossa tectônica de Cococi, preenchida por sedimentos molássicos, durante o Eo-Cambriano.

Outras rochas migmatiticas, em regiões vizinhas, do 
DADOS GEOCRONOLOGICOS PARA A FAIXA JAGUARIBEANA E ALGUNS DADOS PARA O MACIÇO DE TROIA

PONTO NUMERO

ROCHA

MATERIAL

LOCALIDADE

METODO

IDADES

CONVENCIONAIS

REFERENCIAS

Isöcrona de Referência de $2.020 \pm 130 \mathrm{~m} . \mathrm{a} .$, com $\mathrm{RI}=0,707$

In. a.

Rocha Total Ouixadá

$\begin{array}{lll}12 \mathrm{a} & \mathrm{Q}-1 & \text { Gnaisse } \\ 12 \mathrm{~b} & \mathrm{PV}-36 & \text { Gnaisse } \\ 12 \mathrm{C} & \mathrm{PV}-35 & \text { Gnaisse } \\ 12 \mathrm{~d} & \mathrm{PV}-37 & \text { Gnaisse }\end{array}$

$\begin{array}{llll}\text { Rocha Total } & \text { Quixadā } & \mathrm{Rb}-\mathrm{Sr} \\ \text { Rocha } & \text { Total } & \text { Quixadā } & \mathrm{Rb}-\mathrm{Sr} \\ \text { Rocha } & \text { Total } & \text { SW-Quixadā } & \mathrm{Rb}-\mathrm{Sr} \\ \text { Rocha } & \text { Total } & \text { W-Quixadā } & \mathrm{Rb}-\mathrm{Sr}\end{array}$

Isócrona de Referência de $570 \pm 80 \mathrm{~m} . \mathrm{a}$, e RI $=0,707$

Migmatito paleossoma

Rocha Total

Gnaisse listrado

Rocha Total

Caucaia

$\mathrm{Rb}-\mathrm{Sr}$

$S J-B-2$

Migmatito leucossoma

Rocha Total

Caucaia

$\mathrm{Rb}-\mathrm{Sr}$

Gnaisse

Rocha Total

Caucaia

$\mathrm{Rb}-\mathrm{Sr}$

Isócrona Verdadeira de $737 \pm 25 \mathrm{~m} . \mathrm{a} .$, com $\mathrm{RI}=0,706$

Isōcrona de Referência de $550 \pm 65 \mathrm{~m} . \mathrm{a} ., \mathrm{RI}=0,704$

\begin{tabular}{|c|c|c|c|c|c|c|c|}
\hline $12 e$ & $Q-1$ & Gnaisse & Biotita & Quixadā & $\mathrm{Rb}-\mathrm{Sr}$ & & 50 \\
\hline $12 f$ & $Q-1$ & Gnaisse & Hornblenda & Quixađā & $K-A r$ & 530 & 10 \\
\hline $12 \mathrm{~g}$ & $Q-1$ & Gnaisse & Feldspato & Quixadá & $\mathrm{K}-\mathrm{Ar}$ & 452 & 14 \\
\hline $12 \mathrm{~h}$ & $Q-1$ & Gnaisse & Biotita & Quixadā & $\mathrm{K}-\mathrm{Ar}$ & 493 & 14 \\
\hline
\end{tabular}

REFERENCIAS: 1 - BRITO NEVES (1975); 2 - CORDANI (1974); 3 - CPGeo-USP (inēdito); 4 - KAWASHITA et al. (1976) RI = RAZAO INICIAI 


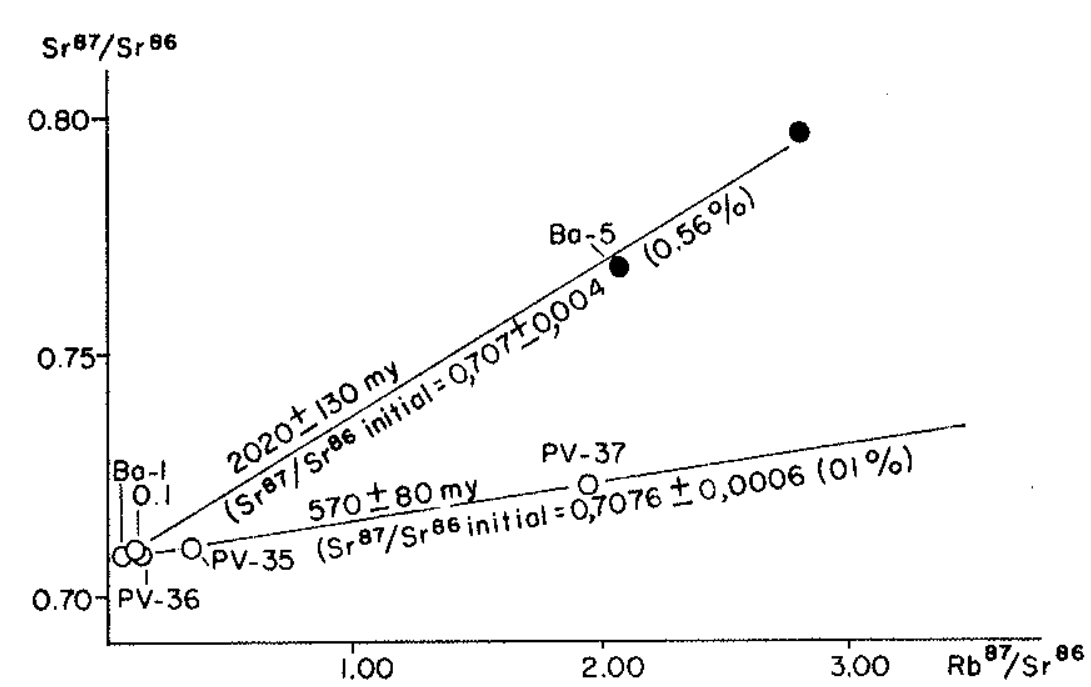

Figura 10 - Isócronas para os gnaisses e migmatitos das regiões de Quixadā e Banabuiu (KAWAsHTTA et al., 1976).

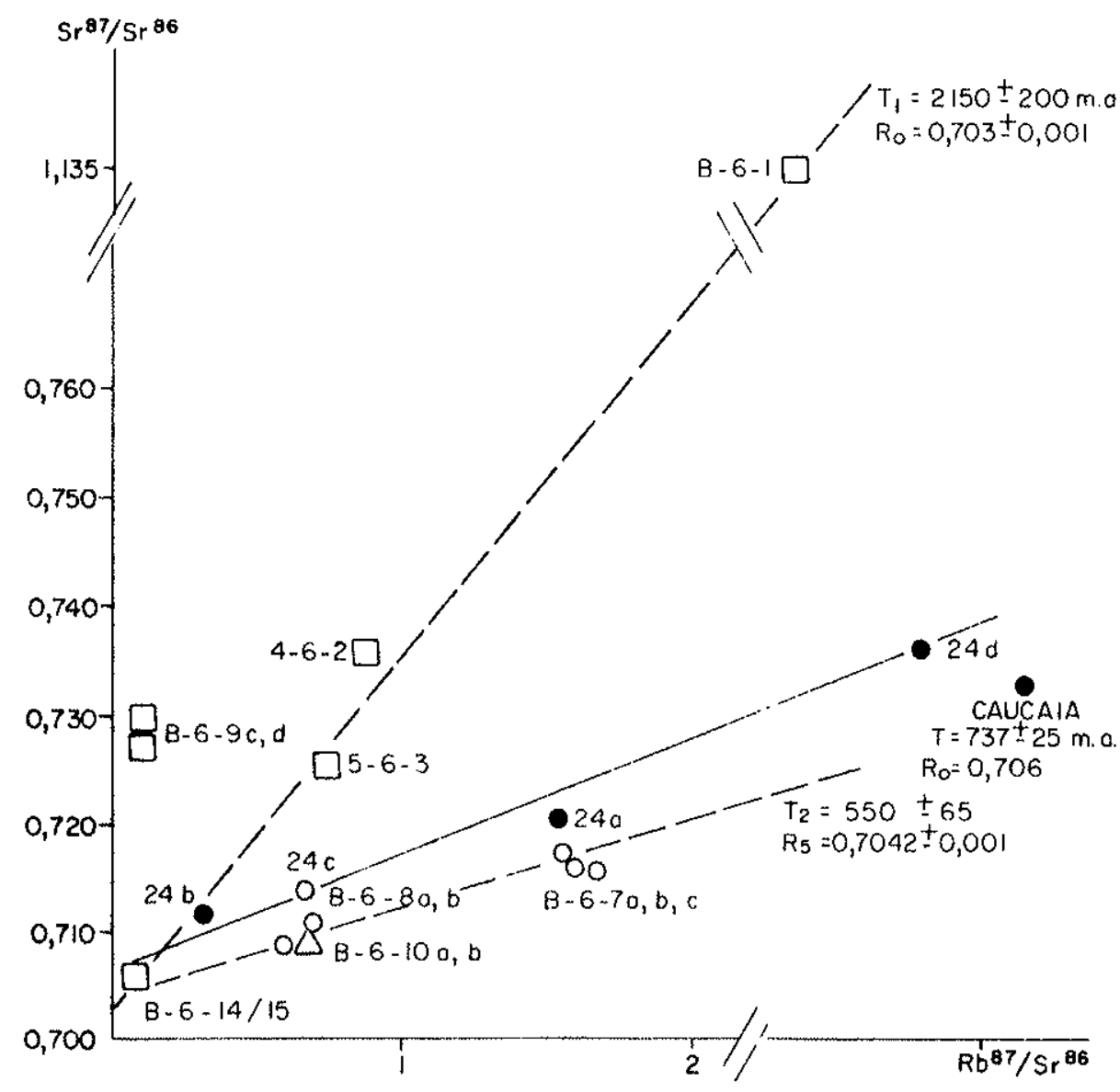

Figura 11 - Diagrama isocrônico para rochas da falxa Jaguaribe e maciço de Tróia (BRITo NEVES, 1975). 
Estado do Ceará (Maranguape), forneceram resultados analíticos interpretados como pertencendo a isócronas brasilianas, com $630 \mathrm{~m} . \mathrm{a}$. (CORDANI, 1974).

Em resumo, a partir de dados geocronológicos disponiveis, é possivel relacionar, para a região de ocorrência de manganês, três eventos importantes:

1 - o ciclo transamazônico, representado na região pela formação de migmatitos e gnaisses do Complexo caicó, com idade aproximada de $2.000 \mathrm{~m}$. a.

2 - O ciclo brasiliano, com idade aproximada de 650 m.a., implantado sobre o embasamento transamazônico e representado na região vizinha por metassedimentos (xistos, quartzitos, etc.) que formam cristas de morros (Boqueirão do Cesārio e Patos) e cujo conjunto constitui o Grupo Cearā.

3 - Evento magmático (e vulcano-sedimentar) pós-orogênico, representado na região por pegmatitos heterogêneos produtores de Be, Li, Ta, etc. (MORAES, 1973), com idade aproximada de $550 \mathrm{~m} . \mathrm{a}$.

7 - GEOLOGIA LOCAL

7.1 - AFLORAMENTOS

Na região de Serragem e Lagoa do Riacho, os afloramentos naturais de rochas manganesiferas ocorrem em baixa altitude (100 a $115 \mathrm{~m})$ e se encontram sempre intemperizados. Camadas alteradas escuras se alternam com camadas alteradas cinza-claras. Cada uma varia de 1 a $10 \mathrm{~cm}$ de espessura, e comumente estão encaixadas por granada-quartzitos em início de alteração.

Estes afloramentos são indicados no campo por blocos rolados e/ou cangas de óxidos de manganês que recobrem o solo nas proximidades. Geralmente este solo coluvial manganesifero 
ocupa uma ārea em torno de $20.000 \mathrm{~m}^{2}$.

Os afloramentos artificiais de Serragem e Lagoa do Riacho são inümeros (Vide Mapas, pág.39 e 41). A partir da descrição das principais escavações (Anexo I) foram confeccionados perfis geológicos C D e E F transversais à direção geral das rochas encaixantes (päg. 40).

Com os dados de furos sonda, cujas perfurações foram empreendidas pela Companhia Siderúrgica Cruzeiro do sul em 1973 , foram confeccionados dois perfis transversais à direção geral das rochas ( $A B$ e $A^{\prime} B^{\prime}$ pág. 39 e 41 ). situados nos mapas geológicos de Serragem e Lago do Riacho, respectivamente.

Os afloramentos de rochas encaixantes na região, por conveniência são descritos no'item 7.3 , relativo à petrografia.

\section{2 - DESCRIÇÃO DE POÇOS E FUROS DE SONDA $7.2 .1-$ POÇOS}

Em Serragem e Lagoa do Riacho existem 64 poços, dos quais 16 são descritos pormenorizadamente e cujos dados (Anexo I) são utilizados para interpretação de estrutura e estratigrafia da ärea. Neste item, é feito uma sintese de todas as descrições, evitando-se assim a descrição poço por poço, por ser muito enfadonha.

Podemos distinguir dois perfis tipicos: um deles,baseado em escavações feitas diretamente sobre o protominério de manganês (Fig. 12); e outro, baseado em escavações feitas diretamente sobre o migmatito-gnaisse e/ou pegmatito (Fig. 13).

o perfil da Figura 12 apresenta, como substrato, o migmatito-gnaisse alterado, constituido macroscopicamente de granada, quartzo e feldspato, e cortado por pegmatito homogêneo, cujo feldspato apresenta estrutura gráfica. Sua espessura não é conhecida por meio de poços. 


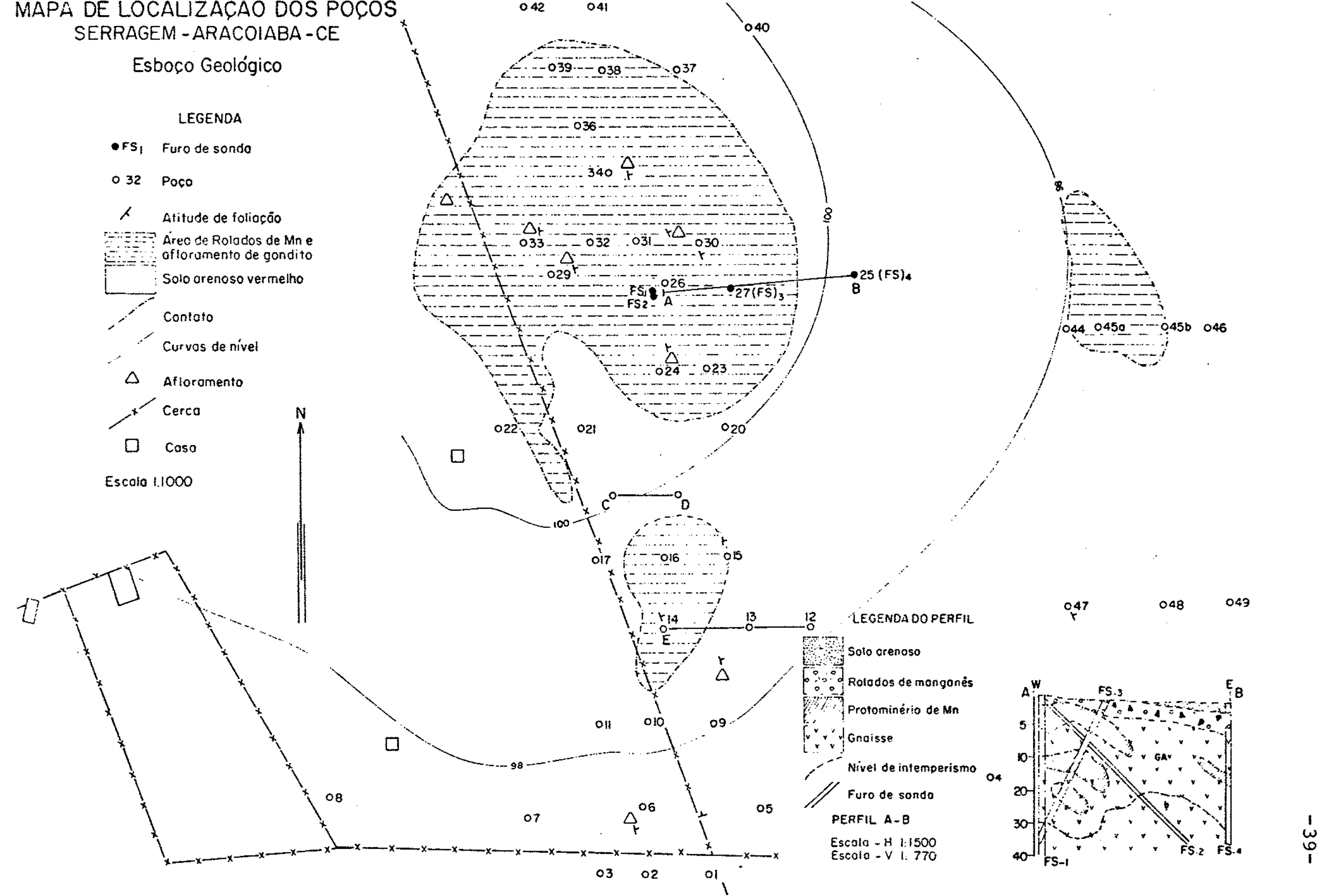




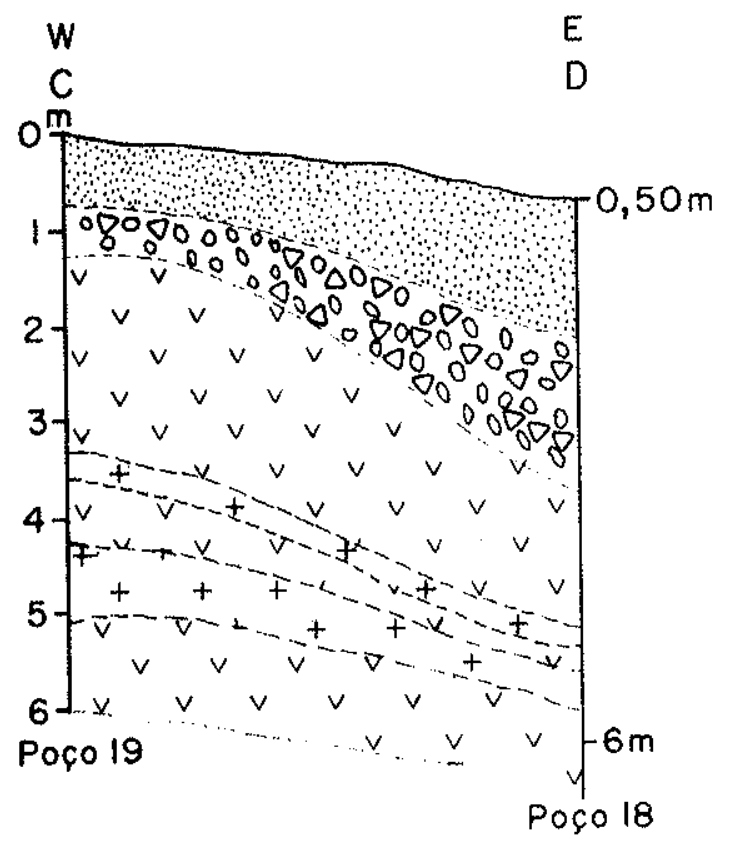

PERFIL CD (SERRAGEM)

PERFIL E-F (SERRAGEM)
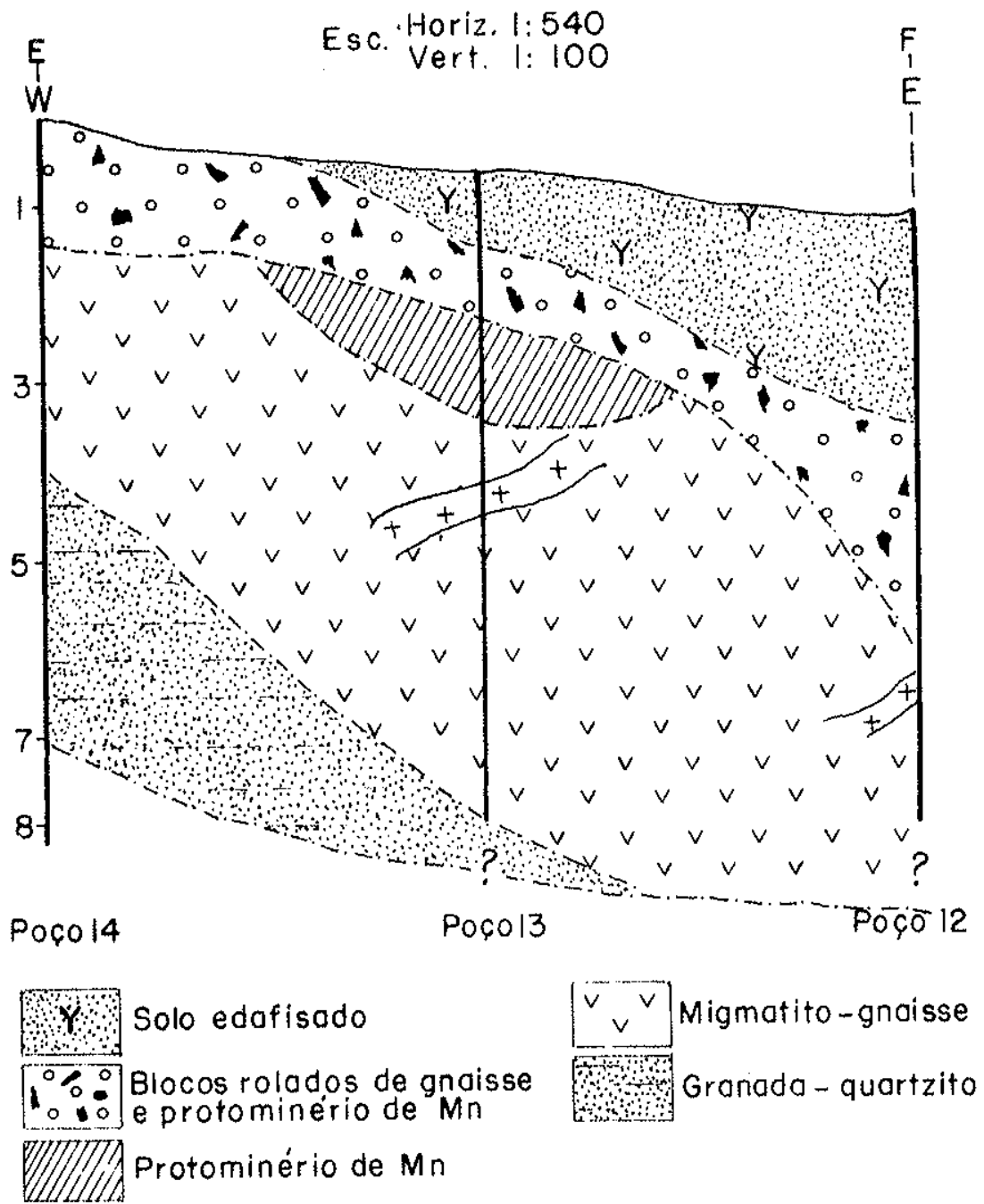


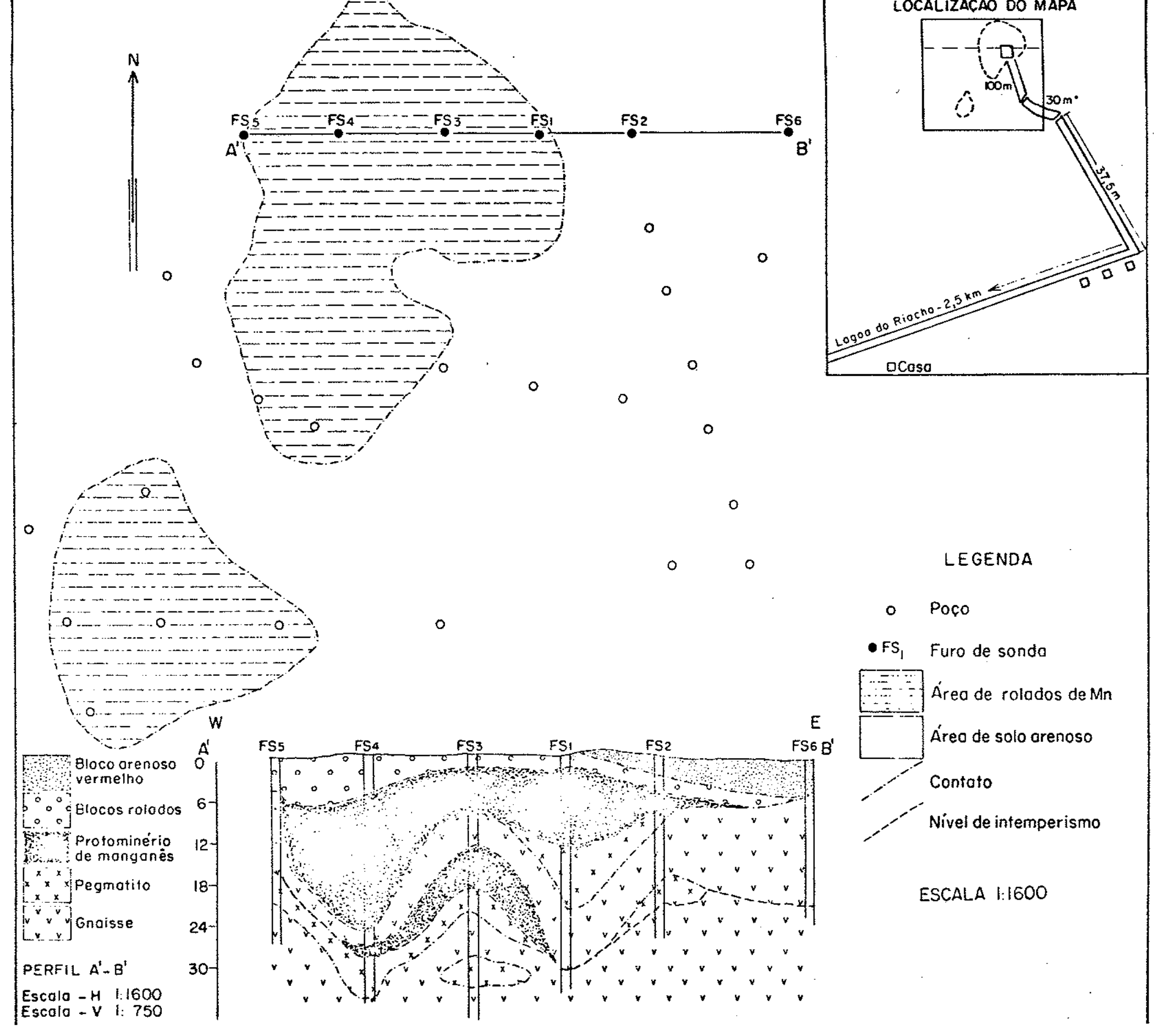


VARIAÇÃO DE
ESPESSURA ESTRATIFICAÇÃO EM $\mathrm{n}$

$0-2,10$
$0-0,30$
$0-0,70$

$0,1-3,00$

$0,2-0,80$

$0-3,50$

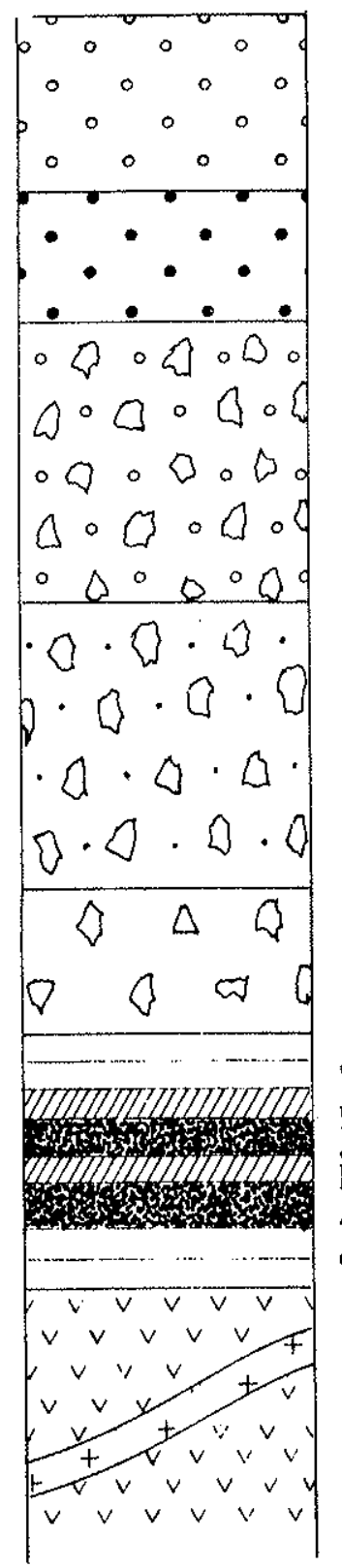

DESCRIÇÃO

Solo de areia vermelha, edafisada de granulação fina e esparsos blocos rolados de protominërio de $\mathrm{Mn}$.

Oxidos de manganês em estruturaconcêntrica e diâmetro de 0,2 a $10 \mathrm{~cm}$.

Oxidos de manganês com estrutura concêntrica de $5 \mathrm{~cm}$ de diâmetro e blocos rolados de $20 \mathrm{~cm}$ de diâmetro.

Blocos rolados de protominério alterado de 30 a $40 \mathrm{~cm}$ de comprimento e poucas esferas de óxidos de manganês,e quartzo e feldspato em pequena quantidade.

Blocos rolados de óxidos de manganês de 5 a $20 \mathrm{~cm}$ de diâmetro.

Protominērios de manganês muito alterado (letra a), alternando com protominérios de manganês pouco alterado (letra b) e com espessartitaquartzito (letra c), rico em almandina,com impregnações de óxidos de manganês.

Migmatito-gnaisse alterado, cortado por pegmatito homogêneo, com estrutura gráfica nos feldspatos.

Figura 12 - Perfil vertical baseado na descrição de poços escavados sobre o protominério (No 15, 16, 20, 34, 39 e 42 em Serragem, e No 1 em Lagoa do Riacho, conforme Anexo I). 
Superimposto ao migmatito-gnaisse, encontra-se um pacote de rochas constituído de granada-quartzito (Fig. 12, letra c) com impregnações de óxidos de manganês e espessura variāvel entre 0,1 a $7,00 \mathrm{~m}$. Neste conjunto de rochas está encaixado o protominério de manganês, em que se observa uma camada muito alterada (Fig. 12, letra a) alternando com outra menos alterada (Fig. 12, letra b). o conjunto do protominério com o granada-quartzito tem uma espessura variável atē $3,50 \mathrm{~m}$ e mergulha $75^{\circ}$ para nordeste.

Acima deste pacote de rochas quartziticas ocorrem blocos rolados de protominérios de manganês de 5 a $20 \mathrm{~cm}$ de diâmetro, com espessura variävel de 0,2 a $0,80 \mathrm{~m}$.

Acima deste nível de blocos rolados, se observa um colúvio constituído de esferas concêntricas de óxidos de manganês e misturados com blocos rolados de protominérios de manganês alterados. A quantidade e tamanho de esferas concêntricas aumentam de baixo para cima, enquanto ocorre o inverso em relação à quantidade e tamanho de blocos rolados. Todo o conjunto varia de 1 a $3,00 \mathrm{~m}$ de espessura.

como cobertura, há um nível de solo arenoso vermelho, de granulação mëdia e, em parte, edafisado, em que se observam esparsos blocos rolados de rochas manganesiferas.

o perfil da Figura 13 apresenta, como substrato, um pegmatito homogêneo com preservação de veios de quartzo ou um migmatito-gnaisse cortado por pegmatito homogêneo.

Acima deste substrato se observa um solo arenoso vermelho, proveniente de alteração de rochas metamórficas. Este fato é inferido a partir da observação de feições (foliação) preservadas nas rochas metamörficas alteradas. A espessura desta camada varia de 0,3 a $2 \mathrm{~m}$.

Superimposto a essa alteração "in situ", observa-se um colúvio de blocos rolados de óxidos de manganês de 1 a $25 \mathrm{~cm}$ de diâmetro, misturado com grãos angulosos de quartzo e felaspato. 
Como cobertura, há uma camada arenosa vermelha, de granulação fina igual à parte superior da Figura 12 .

Variação de

\section{Espessura}

em $\mathrm{m}$

$0-2,30$

$0-1,80$

$0-2,00$

\section{Estratificação}

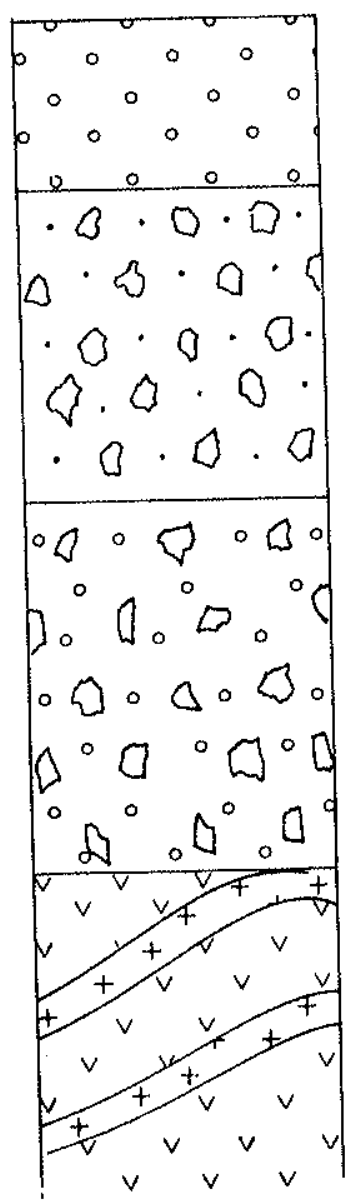

Descrição

Solo arenoso vermelho, eda fisado, de granulação fina

Blocos rolados de óxidos de manganês de 1 a $25 \mathrm{~cm}$ de comprimento, ao lado de blocos angulosos de quartzo e feldspato

Solo arenoso vermelho proveniente de alteração de rocha metamórfica, e blocos de quartzo e feldspato de 0,1 a $2 \mathrm{~cm}$ de diâmetro

Pegmatito homogêneo com preservação de veios de quartzo ou migmatito-gnaisse

Figura 13 - Perfil vertical baseado em descrições de poços escavados sobre gnaisse ou pegmatito (Nrs. 12, 13, 18, 19 e 21 em Sexragem, conforme Anexo II) 


\section{2 .2 - FUROS DE SONDA}

Em Lagoa do Riacho foram feitos seis furos de sonda a diamante, cujas descrições foram utilizadas para construir o perfil transversal A'B' do Mapa Geológico respectivo (pāg.41).

Em Serragem foram utilizadas as descrições de perfis verticais de furos de sonda (Anexo II) para construção do perfil transversal A B do Mapa Geológico da ārea (pāg. 39).

Nos perfis verticais de furos de sonda (Anexo II) observa-se um pacote de rochas constituido de granada-quartzito e de protominério de manganês, com espessura variando de 1,5 a $3 \mathrm{~m}$; estão encaixados em migmatito-gnaisse. Todas as rochas se encontram alteradas até a profundidade de $23 \mathrm{~m}$. Em outros perfis, em Lagoa do Riacho esta profundidade vai até $37 \mathrm{~m}$.

\section{$7.3-$ PETROGRAFIA}

\section{3 .1 - ENCAIXANTES}

\section{$7.3 .1 .1-$ MIGMATITO-GNAISSE}

\section{Migmatito-gnaisse em Serragem e Lagoa do Riacho}

Nos afloramentos artificiais de poços em amostragem de testemunhos de furos de sonda, se observam migmatito-gnaisses de cores cinza a branco, de tonalidades róseas e granulação mēdia a grosseira.

Em Serragem, estas rochas se encontram alteradas atē uma profundidade de $23 \mathrm{~m}$ aproximadamente, enquanto em Lagoa do Riacho se encontram alteradas atē $37 \mathrm{~m}$.

No migmatito-gnaisse é observada uma textura granoblástica e composição mineralógica seguinte: quartzo (70\%), pertita (3\%), plagiocläsio-An 28 (14\%), biotita ( $<4 \%$ ), almandina (5\%), silimanita $(<1 \%)$ e apatita (<1응). 
Existem lentes concordantes de pegmatitos homogêneos localizadas geralmente em nücleos de sinformes e antiformes. Suas dimensões variam de 20 a $50 \mathrm{~m}$ de comprimento e de 3 a $8 \mathrm{~m}$ de largura. O perfil transversal A'B'do Mapa Geológico de Lagoa do Riacho (pāg.41) mostra quatro lentes em relação ao protominērio e ao gnaisse.

Macroscopicamente, nestes pegmatitos se observam quart zo, mica, feldspato e grafita em palhetas. Microscopicamente ē descrita a seguinte composição mineralógica: biotita, quartzo, plagioclásio, grafita, microclíneo e pertita.

\section{Migmatito-gnaisse no Serrote Pelado}

Nas āreas mais próximas a Serragem e Lagoa do Riacho, o migmatito-gnaisse é representado geomorfologicamente pelo Serrote Pelado e pelo serrote ocara.

o Serrote pelado é um grande afloramento de migmatito-gnaisse em que se alternam camadas de almandina e biotita e camadas de feldspato, com uma foliação de direção $\mathrm{N}-\mathrm{S}$ e mergulho $80^{\circ} \mathrm{W}$. Não está comprovado que se trata de um migmatito na acepção de MENHERT (1971), mas descritivamente trata-se de um migmatito estromatitico.

O migmatito-gnaisse do serrote pelado, em amostra de mão, tem aparência de um biotita-granada gnaisse tipo kinzigito (HEINRICH, 1960) em que as granadas são porfiroblāsticas (diâmetro de 1 a $5 \mathrm{~mm}$ ) e concordantes com a foliação; no entanto, falta cordierita para classificä-lo como tal.

Esta rocha tem coloração branca com tonalidade rósea em função da granada e possui granulação grosseira.

Ao microscópio, possui textura granoblástica e composição mineralógica constituía de: quartzo (65\%), almandina (3\%), biotita (12\%), plagioclásio-An 28 (14\%), silimanita (<3\%) e ortocläsio $(<3 \%)$.

Todo o conjunto de migmatito-gnaisse é cortado por 
veios pegmatitos homogêneos. Uns são concordantes (Fig. 14, 1etra c), com espessura variando entre 2 a $30 \mathrm{~cm}$. Outros são discordantes (Fig. 14, letra b), com espessura variando entre 0,5 a $1,2 \mathrm{~m}$.

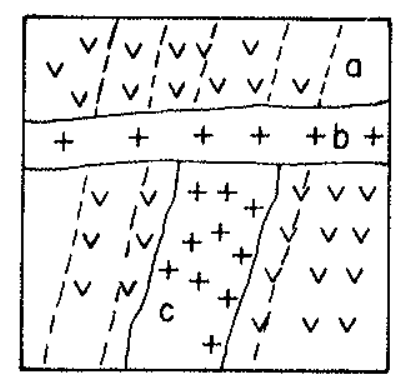

$a=$ Foliaçāo do

migmatito-gnaisse

$b=$ Pegmatito discordante

$c=$ Pegmatito concordante

Figura 14 - Migmatito-gnaisse (a) cortado por pegmatito homogêneo concordante (c) de 0,5 a $1,2 \mathrm{~m}$ de espessura e por pegmatito homogêneo discordante de 2 a $30 \mathrm{~cm}$ de espessura (b).

O pegmatito possui a seguinte composição: quartzo (60\%), plagioclásio (30\%) e biotita (10\%).

Uma rocha, de coloração cinza-escura e granulação variāvel de fina a grosseira, corta discordantemente o migmatito-gnaisse, na direção $\mathrm{N}-\mathrm{S}$ com mergulho de $60^{\circ} \mathrm{E}$ (Fig. 15). A parte de granulação fina de cristais de quartzo alinhados apresenta exfoliação "em cebola" nas partes aflorantes (Foto no 3). Sua granulação fina se deve ao fenômeno de cataclase que atuou fortemente sobre ela. Microscopicamente esta rocha tem textura granoblástica e composição mineralógica seguinte: quartzo (70\%), plagioclásio (23\%), microclina (2\%), ortoclásio (2\%), biotita e muscovita em pequena quantidade. Trata-se de uma rocha granitóide rica em quartzo, conforme nomenclatura em STRECKEISEN (1973). 


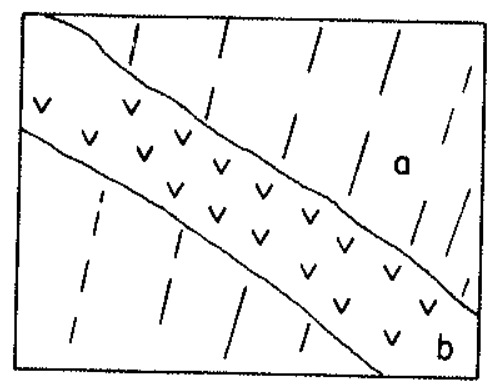

Figura 15 - Migmatito-gnaisse(a) cortado por granitöide catacläs tico $(b)$.

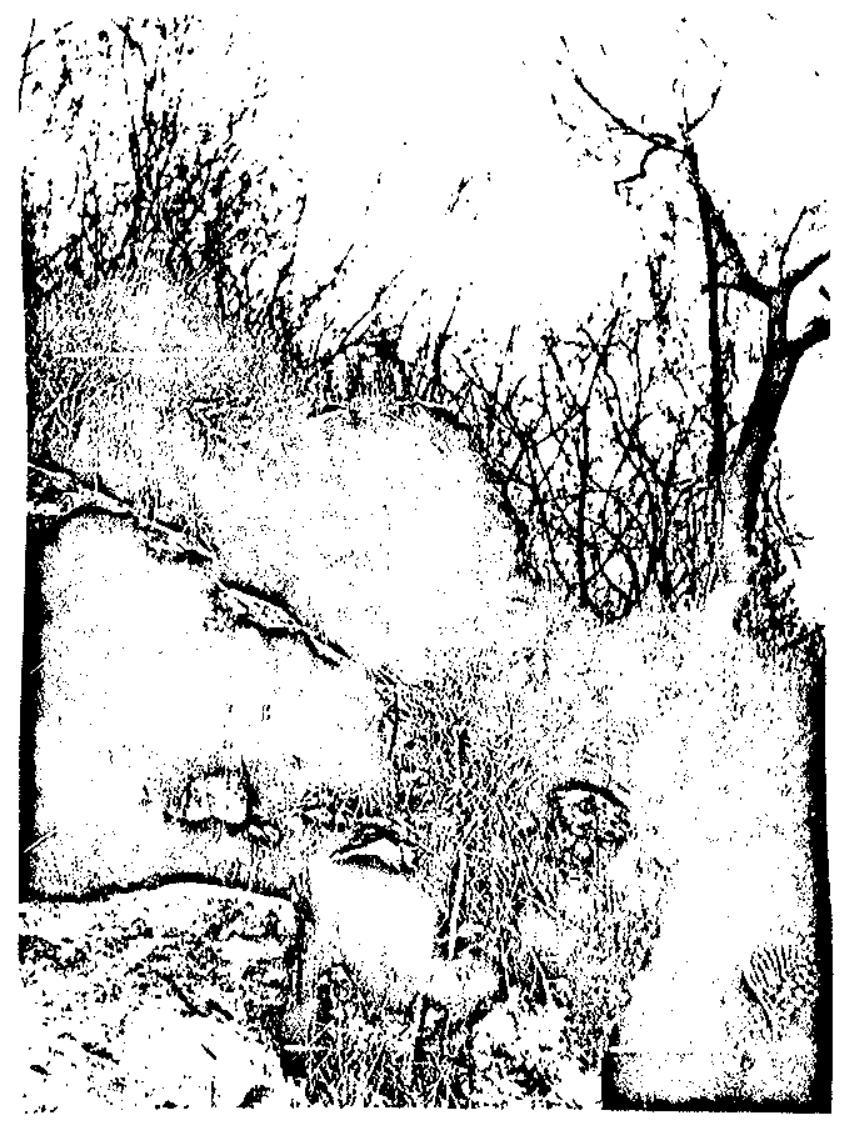

Foto 3 - Exfoliação(A) do granitóide cataclāstico da Figura 15. Na parte SW da Fotografia se observa o granodiorito sem foliação em blocos rolados. 


\section{Migmatito-gnaisse no Serrote ocara}

O migmatito-gnaisse aflorante no serrote Ocara (Foto no 2) possui direção de foliação de $20^{\circ} \mathrm{NW}$ com mergulho de $40^{\circ} \mathrm{NE}$. Observam-se faixas de feldspato de $1 \mathrm{~mm}$ até $30 \mathrm{~cm}$ de espessura concordantes com a foliação.

Nos flancos do serrote são observadas lentes concordantes de quartzo de $4 \mathrm{~m}$ de comprimento por $50 \mathrm{~cm}$ de largura. Intercalado no gnaisse existe uma rocha dura, compacta, de aparência avermelhada, constituída essencialmente de: almandina (80\%), quartzo (10\%), hornblenda (4\%), apatita e titanita (1\%). Trata-se de um granoblastito tipo granatito.

No sopé do serrote se encontra uma rocha friável,xistosa e composta essencialmente de biotita e hornblenda verde oliva (80\%), de quartzo e granada (15\%) e apatita como acessório. Trata-se de um hornblenda-xisto com textura granoblástica.

O serrote de ocara constitui um sinforme de direção $20^{\circ} \mathrm{NW}$ com plunge para $\mathrm{SE}$.

7.3.1.2 - MIGMATITO-GNAISSE, MIGMATITO-BASICO E METABASITO DA REGIÃO DE CHOROZINHO (PACAJOS)

Na região de Chorozinho, nas localidades de Morros e Fiúza, afloram o migmatito-gnaisse (semelhante aos de serragem, Lagoa do Riacho, serrote Pelado e Ocara), o migmatito-básico e metabasitos, conforme esquema da Figura 16.

Em Morros, o migmatito-gnaisse forma pequenas elevações (5 a $8 \mathrm{~m}$ de altura); possui granulação grosseira, apresentando faixas de. feldspato em grão de $5 \mathrm{~cm}$ de diâmetro, alternando com faixas de quartzo e feldspato de $1 \mathrm{~mm}$ de diâmetro.

A rocha tem direção geral $\mathrm{N}-\mathrm{S}$ e mergulho $60^{\circ} \mathrm{E}$.

A composição mineralógica é igual à dos migmatito-gnaisses descritos anteriormente. 
o migmatito básico aflora como lentes encaixađas no migmatito-gnaisse. Tem cor escura, aspecto compacto e granulação grosseira. Possui textura granoblästica e composição mineralögica seguinte: clinopiroxênio e ortopiroxênio (70\%), microclíneo (5 a 8\%), plagioclásio - An 48 (5 a 8\%), quartzo (8\%), biotita (2\%), hornblenda (2\%), ilmenita e magnetita como acessórios opacos.

Encaixado no migmatito bäsico se encontra uma rocha escura, de granulação fina a afanitica. Possui textura granoblāstica e composição mineralōgica constituỉa de: ortoclásio com exsoluções de albita (1\%), clinopiroxênio e ortopiroxênio ( $\pm 75 \%$ ), plagioclásio - An 45 (2 a 8\%), quartzo ( 3 a 5\%), ilmenita e magnetita (2 a 5\%). Trata-se de um metabasito que ocorre em baixadas ou como inclusão no migmatito bāsico (Fig. 16, letra c). o contato com o migmatito básico não é observado diretamente.

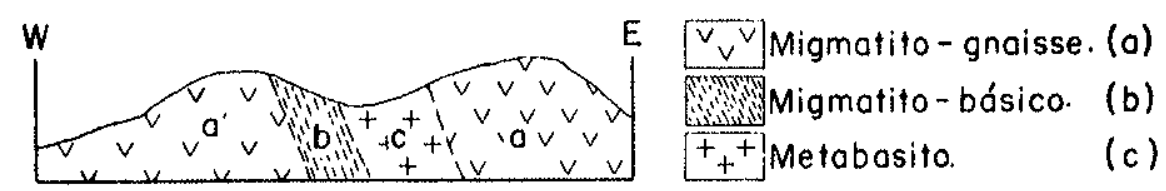

Figura 16 - Perfil esquemātico de ocorrências de migmatito-gnaisse (a) migmatito bäsico (b) e metabasito (c) em Morros (Chorozinho-CE). 
$7.3 .1 .3-$ QUARTZITOS

\section{Silimanita-quartzito no Serrote Curupira}

o serrote vizinho ao povoado de Curupira é constituido de quartzito de aparência rósea amarronzada, de estrutura compacta e granulação fina.

A foliação tem direção geral $\mathrm{N}-\mathrm{S}$ e mergulho de $60^{\circ} \mathrm{pa-}$ ra leste. Este quartzito duro e compacto no topo e nos flancos do serrote passa a um quartzito xistoso e friável na base.

Possui textura grano-lepidoblástica com quartzo alongado no sentido da foliação e porfiroblastos de almandina de tamanho variāvel entre 0,1 a $5 \mathrm{~mm}$. Sua composição mineralógica é a seguinte: quartzo (93\%), biotita (1\%), granada (2\%), silimanita (3\%) e limonita (1\%). Trata-se, portanto, de um biotita-almandina-silimanita quartzito.

o quartzo se apresenta sempre fraturado na direção perpendicular à foliação. A limonita ocorre junto à granada, indicando derivar-se por sua alteração.

\section{Quartzito em Serragem e Lagoa do Riacho}

Encontra-se um granada-quartzito na região de Serragem e Lagoa do Riacho, em afloramentos artificiais de poços e em amostragem de furos de sonda. Está encaixado entre o migmatito-gnaisse e o protominērio de manganês, com espessura variável de 0,1 a $3,50 \mathrm{~m}$. Possui cor cinza escura e granulação mẻdia. Sua composição mineralögica é a seguinte: granada (80\%), quartzo (15\%) e apatita. A textura é granoblästica.

Aparentemente esta granada seria xica em espessartita, mas anälise pelo método de MADUREIRA FILHO (1972) e CAMARGo \& MADUREIRA FILHO (1976) resultou na seguinte composiçãc molecular: almandina (72\%), piropo (19\%), espessartita (5\%) e grossulāria (12\%). Isto indica que a rocha contēm mais CaO que Mno. 


\section{Quartzito no serrote cotas}

A sudeste de Lagoa do Riacho, aflora um quartzito que modela o serrote Cotas, situado na Eronteira SE das ocorrências de $\mathrm{Mn}$. Tem aparência branca, granulação média (2 mm).

Possui textura granoblāstica e composição mineralógica de: quartzo (96\%), biotita (3\%) e silimanita (rara). Trata-se de um biotita-quartzito.

\section{3 .2 - PROTOMINERIO DE MANGANES}

o protominério de manganês, juntamente com almandina-quartzito, aflora em elevações de 3 a $5 \mathrm{~m}$, onde se encontra em meio a blocos rolados e esferas concêntricas de öxidos de manganês.

Baseado nas descrições de poços e furos de sonda, foi desenhado um perfil esquemático que mostra com clareza o posicionamento do protominërio de manganês em relação a outras rochas jä descritas (Fig. 17).

o protominério tem direçäo $\mathrm{N} 80^{\circ} \mathrm{W}$ e mergulho que varia de $50^{\circ}$ a $75^{\circ} \mathrm{E}$. Sua espessura varia de $0,10 \mathrm{~m}$ a $3,50 \mathrm{~m}$. Está encaixado num conjunto de rochas constituido de migmatito-gnaisse e almandina-quartzito; ocupa o núcleo de um sinforme e se acha recoberto por niveis de material rolado e de material clástico (Fig. 17).

Em amostra de mão e em escala de afloramento, se observa um bandeamento de camadas claras (granada-quartzito) e camadas escuras (protominério alterado). Ao microscöpio este bandeamento também é observado, embora näo muito claramente.

Em estudo de seções polidas são observadas texturas deposicionais em mosaico, textura bandeada, textura de limites mútuos e texturas de inclusão. Estas e outras texturas são descritas posteriormente. 


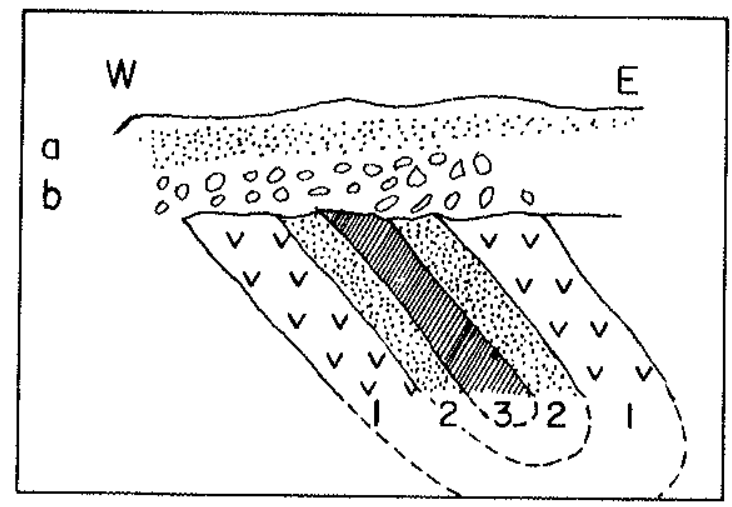

Figura 17 - Perfil vertical esquemätico das ocorrências de manganês de Serragem e Lagoa do Riacho; construido a partir das descrições de furos de sonda: 1-migmatito-gnaisse; 2-granada-quartzito; 3-protominério de manganês; a-solo arenoso; b-blocos rolados e esferas concêntricas de óxidos de manganês. o gondito ocupa o núcleo de um dobramento sinclinal isoclinal.

Em lâminas delgadas, a composição mineralógica média è a seguinte: quartzo (20\%), espessartita (75\%), mangano-cumingtonita e rodonita $(<2 \%)$, pirita e pirrotita em pequena quantidade.

BRAGA et $\alpha$. (1977) informa a existência de rodocrosita no protominério, entretanto, no decurso de nosso trabalho de campo e de laboratório não se verificou sua ocorrência.

Pelas observações anteriores se determinaram as seguintes paragêneses:

$$
\begin{aligned}
& 1 \text { - quartzo - espessartita - pirita e pirrotita } \\
& 2 \text { - rodonita-espessartita - quartzo - mangano-cuming- }
\end{aligned}
$$
tonita.

Considerando o diagrama triangular em que está repre-

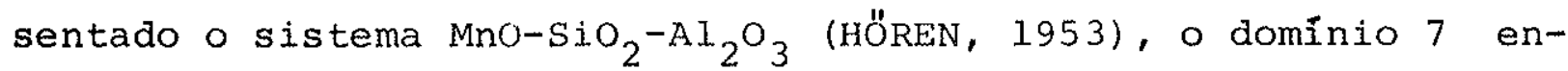
globa as condições quimicas do protominērio de manganês da ārea de Serragem e Lagoa do Riacho (Fig. 18). 


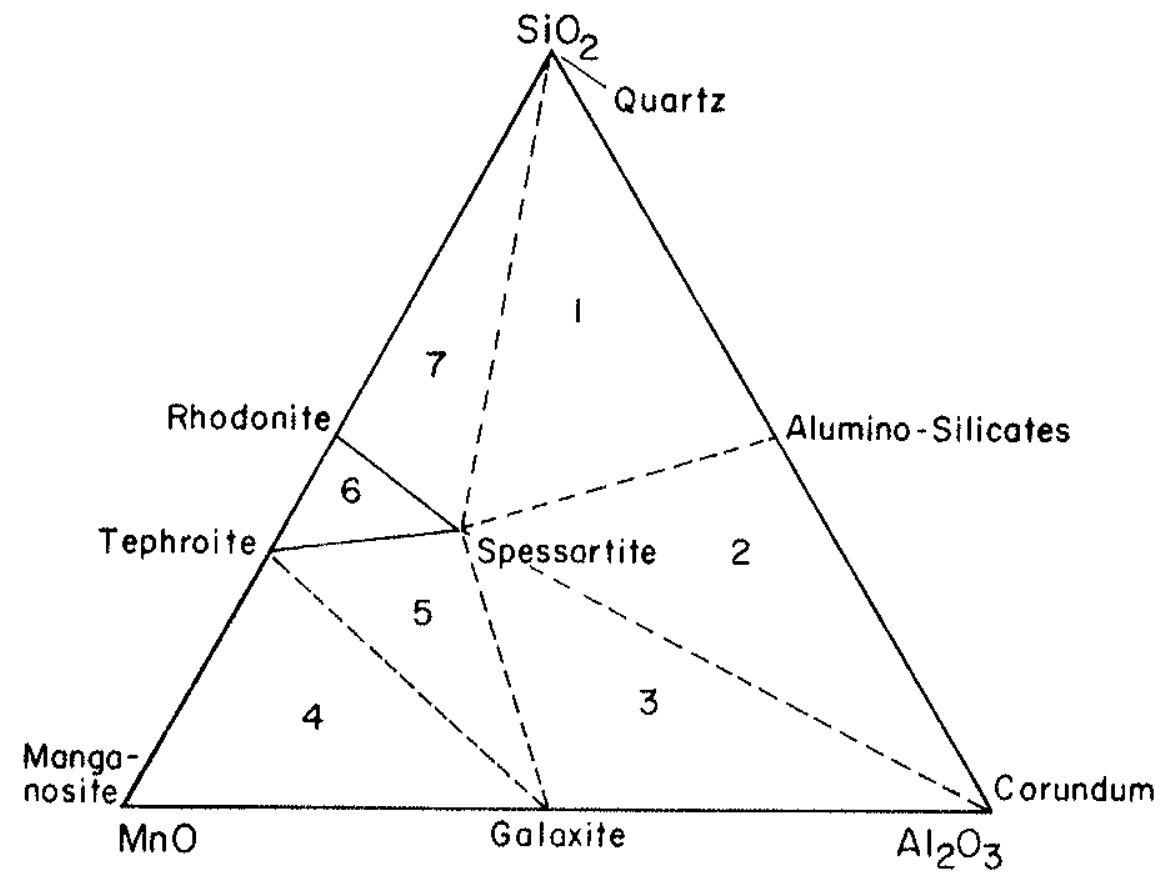

Figura 18 - Associação mineral no sistema MnO-SiO ${ }_{2} \mathrm{Al}_{2} \mathrm{O}_{3}$ (HÖREN, 1953)

o dominio 7 engloba as condições do protominërio em estudo.

Segundo HOLTROP (1965) é importante para definição do tipo de protominērio silicático a percentagem de composição em anfibólio. Para isso construiu o diagrama triangular cujos vértices são ocupados por quartzo e espessartita na base,e por anfibólio no vértice superior (Fig. 19). A percentagem de espessartita e de quartzo varia entre 20 e $80 \%$ e a percentagem de anfibólio é Infima ( $<2 \%$ ) (Vide Quadro 3, pāg.55); deste modo este protominério se situa no domínio do gondito, pröximo à linha de base do diagrama triangular (Fig. 19).

Na Figura 19 notam-se variações em que podem estar presentes outros minerais, como grafita e rodonita.

Trata-se, portanto, de um protominério silicático tipo gondito, conforme a conceituação de HOLTROP (Op.Cit.), embora não seja um gondito na acepção genética preconizada por ROY (1968). 
QUADRO 3

COMPOSIÇÃO DO PROTOMINERIO DE MANGANES DA PROVINCIA MANGANESIFERA DE ARACOIABA-PACAJUS (CE).

\begin{tabular}{|c|c|c|c|c|c|}
\hline NOMERO & QUARTZO & $\begin{array}{l}\text { GRANADA } \\
(\text { Esp.) }\end{array}$ & $\begin{array}{l}\text { Mn-CUMINGTONITA } \\
\text { RODONITA }\end{array}$ & SULFETOS & OPACOS \\
\hline 1 & 33 & 38 & - & - & 28 \\
\hline 2 & - & 10 & 3 & - & 87 \\
\hline 3 & - & 83 & 2 & - & 15 \\
\hline 4 & - & 69 & 4 & - & 25 \\
\hline 5 & 11 & 35 & $I$ & - & 53 \\
\hline 6 & 38 & 21 & 1 & - & 40 \\
\hline 7 & - & - & 4 & - & 96 \\
\hline 8 & 3 & 70 & 1 & 0,1 & 25 \\
\hline 9 & 20 & 77 & 1 & $0, i$ & 2 \\
\hline 10 & 40 & 50 & 1 & 0.1 & 8 \\
\hline 11 & - & 90 & 1 & 0,1 & 8 \\
\hline 12 & - & 85 & - & 0,1 & 13 \\
\hline 13 & 55 & 43 & 1 & 0,1 & 4 \\
\hline 14 & 5 & 90 & 1 & 0,1 & 4 \\
\hline 15 & 5 & 10 & 4 & 0,1 & 80 \\
\hline 16 & 40 & 50 & - & 0,1 & 8 \\
\hline 17 & 45 & 48 & - & - & 3 \\
\hline 18 & 45 & 45 & 1 & 1,0 & 8 \\
\hline
\end{tabular}

Baseado em dados ( 1 a 7) de CRUzuL (1975) e em dados de secções polidas e lâminas delgadas (por estimativa). 


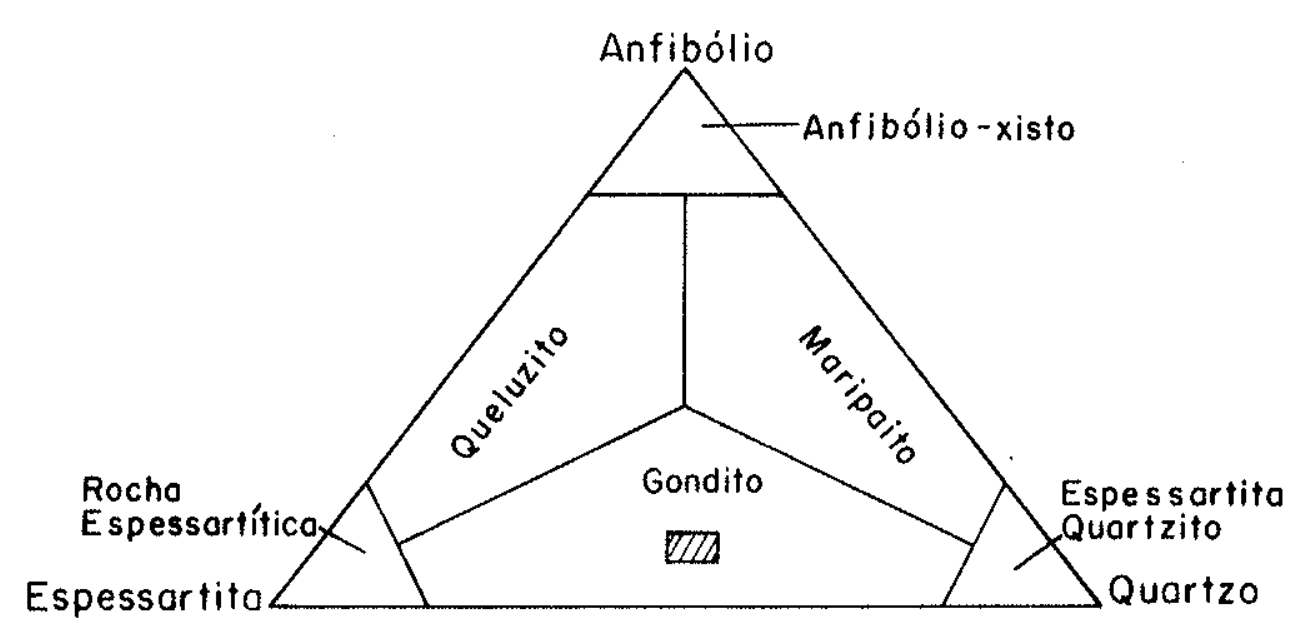

\section{Espessartita}

Figura 19 - Diagrama triangular para classificação de rocha com espessartita, quartzo e anfibólio(HOLTROP, 1965) O quadrado hachuriado representa o protominério de Serragem e Lagoa do Riacho (Aracoiaba-CE).

\section{4 - MTNERALOGIA DO PROTOMINERIO}

São descritas neste item as principais propriedades dos minerais encontrados no gondito.

As técnicas utilizadas para esta descrição são apresentadas com pormenores no capítulo sobre metodologia.

Posteriormente, algumas destas informações serão retomadas, ao se fazer anālises sobre as condições de metamorfismo.

\section{Rodonita}

A rodonita è reconhecida em filme de raios X(Tabela 2). E facilmente confundível com a piroxmangita, uma vez que as distâncias interplanares padrões são extremamente semelhan tes.

Em seção delgada, foram observadas seções basais com clivagens em ângulo reto e extinção oblíqua. Neste caso também hã uma fácil confusão com piroxmangita. No entanto, os valores 
TABELA 2

DISTÃNCIAS INTERPLANARES (dA) OBTIDAS POR DIFRAÇÃO DE RAIOS $\mathrm{x}$ (FILME) EM RADIAÇÃO FEKa, COMPARADAS COM PADRÕES ASTM (1965)

\begin{tabular}{|c|c|c|c|c|c|c|c|}
\hline \multirow{2}{*}{\multicolumn{2}{|c|}{ AMOSTRA }} & \multicolumn{6}{|c|}{ PADRÃO } \\
\hline & & \multicolumn{2}{|c|}{ Min-CUMINGTONITA } & \multicolumn{2}{|c|}{ RODON ITA } & \multicolumn{2}{|c|}{ PIROLUSITA } \\
\hline$d A$ & I/IO & $d A$ & I/Io & $d A$ & I/Io & $\mathrm{dA}$ & I/IO \\
\hline 8,30 & 10 & 8,30 & 90 & & & & \\
\hline 7,07 & 8 & & & 7,15 & 4 & & \\
\hline 6,54 & 10 & & & 6,68 & 8 & & \\
\hline 5,99 & 15 & & & & & & \\
\hline 4,09 & 2 & & & 4,10 & 1 & & \\
\hline 3,79 & 2 & & & 3,78 & 1 & & \\
\hline 3,53 & 25 & & & 3,57 & 14 & & \\
\hline 3,31 & 30 & & & 3,34 & 25 & & \\
\hline 3,12 & 60 & & & 3,10 & 25 & & \\
\hline 3,06 & 60 & & & 3,07 & 4 & & \\
\hline 2,95 & 70 & & & 2,92 & 65 & & \\
\hline 2,90 & 80 & & & & & & \\
\hline 2,73 & 30 & & & 2,77 & 100 & & \\
\hline 2,59 & 100 & & & 2,59 & 16 & & \\
\hline 2,49 & 20 & & & 2,48 & 8 & & \\
\hline 2,36 & 10 & & & 2,38 & 4 & & \\
\hline 2,21 & 20 & & & & & 2,21 & 10 \\
\hline 2,16 & 20 & & & & & 2,13 & 25 \\
\hline 1,88 & 30 & & & & & 1,98 & 15 \\
\hline 1,71 & 10 & & & & & 1,81 & 5 \\
\hline 1,68 & 5 & & & & & 1,68 & 1 \\
\hline
\end{tabular}

$1,61 \quad 20$

$1,61 \quad 40$

$1,58 \quad 10$

$1,58 \quad 30$

1,5530

$1,55 \quad 25$

$1,50 \quad 5$

$1,50 \quad 40$

$1,46 \quad 5$

$1,48 \quad 30$

$1,45 \quad 5$

1,45

30

$1,42 \quad 30$

1,42

10

$1,29 \quad 10$

1,29

35

$1,28 \quad 10$

$1,279 \quad 10$

$1,26 \quad 5$

1,26

$1,24 \quad 5$

1,25

5

$1,08 \quad 30$

1,08

$1,06 \quad 5$

1,05

$1,02 \quad 15$

1,03 
TABELA 3

DISTANCIAS INTERPLANARES (dA) OBTIDAS POR DIFRAÇÃO DE RAIO X (FILME) EM RADIAÇÃO FEK $\alpha$, COMPARADAS COM PADRÃO ASTM(1965)

\begin{tabular}{|c|c|c|}
\hline & \multicolumn{2}{|c|}{ PADRÃO } \\
\hline $\begin{array}{l}\text { AMOSTRA } \\
\text { ( } \mathrm{filme)}\end{array}$ & $\begin{array}{l}\text { ESPESSARTITA } \\
\text { Cart. } 2-0992\end{array}$ & $\begin{array}{c}\text { QUAARTzO } \\
\text { Cart. 5-0490 }\end{array}$ \\
\hline I/IO & I/IO & I/IO \\
\hline
\end{tabular}

$3,35 \quad 10$

$2,90 \quad 20$

$2,90 \quad 50$

$3,34 \quad 100$

$2,60 \quad 100$

$2,60 \quad 100$

$2,48 \quad 5$

$2,48 \quad 5$

$2,37 \quad 10$

$2,37 \quad 20$

$2,28 \quad 10$

$2,28 \quad 20$

$2,12 \quad 30$

$2,12 \quad 20$

$2,22 \quad 30$

2,23

6

$1,68 \quad 40$

$1,68 \quad 40$

$1,61 \quad 50$

$1,61 \quad 60$

$1,57 \quad 10$

$1,58 \quad 3$

$1,45 \quad 10$

$1,45 \quad 20$

$1,30 \quad 20$

$1,30 \quad 40$

$1,31 \quad 10$

$1,30 \quad 40$

$1,08 \quad 20$

$1,08 \quad 70$

1,08

4

$1,06 \quad 20$

$1,06 \quad 60$

1,06

1 
do ângulo $2 \mathrm{~V}$ do mineral, medidos por estimativa, se situam sempre acima de $60^{\circ}$. Sabe-se que o ângulo $2 \mathrm{~V}$ da piroxmangita se situa entre 34 e $46^{\circ}$ e o da rodonita entre $61^{\circ}$ e $76^{\circ}$.

\section{Mangano-cumingtonita}

A mangano-cumingtonita ē monoclínica, entretanto suas propriedades quỉmicas e ópticas são semelhantes à antofilita,que é ortorrômbica (CHAKRABORTY, 1963).

Em seção delgada é incolor a verde pálido. o ângulo de extinção é mais alto que o comum das cumingtonitas. Possui sinal óptico negativo. O ângulo $2 \mathrm{~V}$ é igual a $80^{\circ}$

Este mineral foi detectado em análise de pó por raios $\mathrm{x}$, em mistura com rodonita (Tabela 2).

A mangano-cumingtonita e a rodonita compõem até $4 \%$ do protominério alterado. Entretanto, as percentagens mais comuns são iguais ou menores que 1 (Quadro 3).

\section{Granada (Espessartita)}

E facilmente identificada a granada, em seção delgada, pela isotropia e a forma.

A variedade espessartita é detectada em filmes de raios X (Tabela 3) pelo padrão ASTM. No entanto, sua composição molecular não é făcil obter, tendo em vista que todo grão está alterado, dificultando a medição de densidade e índice de refração. Entretanto, sabe-se, com certeza, que se trata de uma granada, cuja percentagem maior pertence à fase espessartita, tendo em vista a composição do material alterado (Tabelas 11, 12 e 14), a composição mineralógica e textura do protominério.

A espessartita é equigranular e idioblástica, e está limitada por arestas (110) formando seções quadradas e hexagonais e constituem o protominério de manganês.

outra granada foi identificada a partir da constata- 
TABELA 4

VALORES DE DIFERENÇA DE $2 \theta$ PARA FEK $\alpha$, E SUA TRANSFORMAÇÃO PARA CUK $\alpha$, RELATIVOS ȦS GRANADAS

\begin{tabular}{|c|c|c|c|c|c|c|c|c|}
\hline NO & $\mathrm{ROCHA}$ & $a_{0}(\AA)$ & $d(420)$ & $2 \theta(420)$ & $\begin{array}{c}2 \stackrel{\theta}{\text { Quartzo }} \\
\text { Quartion }\end{array}$ & $\begin{array}{l}\Delta 2 \theta \\
F e K \alpha\end{array}$ & $\begin{array}{l}\text { Valor de } \\
\text { correção }\end{array}$ & $\begin{array}{r}\Delta 2 \theta \\
\operatorname{CuK} \alpha\end{array}$ \\
\hline 1 & $\begin{array}{l}\text { Granada do } \\
\text { migmatito- } \\
\text { gnaisse }\end{array}$ & 11,568 & 2,586 & 43,96 & 33,66 & 10,30 & 0,7958 & 8,19 \\
\hline 2 & $\begin{array}{l}\text { Granada do } \\
\text { quartzito }\end{array}$ & 11,596 & 2,592 & 43,83 & 33,66 & 10,17 & 0,7958 & 8,09 \\
\hline
\end{tabular}

Obs.: a calculado conforme Anexo IV

TABELA 5

\begin{abstract}
VALORES DE PROPRIEDADES FÍSICAS DE GRANADAS
\end{abstract}
Nㅇ.

1

2 a ( $)$

11,568

11,596 n

1,800

1,795
D

3,87

3,70
$\Delta 2 \theta$

8,19

8,09 
TABELA 6

PERCENTAGENS DE COMPOSIÇÃO MOLECULAR OBTIDAS DE DIAGRAMAS TRIANGULARES PELO MÉTODO DE MADUREIRA FILHO (1972) E CAMARGO E MADUREIRA FILHO (1976) (AMOSTRA 2 DA TABELA 5), COMPLEMENTADA PARA COMPOSIÇÃO QUATERNARIA CONFORME MADUREIRA FILHO (COMUNICAÇÃO VERBAL, 1979).

RESULTADOS DE DIAGRAMA TERNARIO

\begin{tabular}{l|lc}
\hline GRUPO & $n-\Delta 2 \theta(\%)$ & $\Delta 2 \theta-\mathrm{D}(\%)$ \\
\hline 1 & Alm. -68 & Alm. -16 \\
Pir. -22 & Pir. -66 \\
Gr. -10 & Gr. -18 \\
& Alm. -59 & Alm. -10 \\
& Pir. -33 & Pir. -69 \\
& And. -8 & And. -21 \\
\hline
\end{tabular}

RESULTADOS DE DIAGRAMA QUATERNARIO

$$
\begin{aligned}
& \text { Alm. - } 64 \% \\
& \text { Pir. - } 19 \% \\
& \text { Esp. - } 5 \% \\
& \text { Gr. - } 12 \%
\end{aligned}
$$


ção de que hã uma granada quase inalterada como componente prin cipal do quartzito encajxante do gondito. Ela permanece com a cor beje clara, formando, às vezes, bolsões isolados dentro do gondito, onde podem ser encontrados cristais bem formados.

A partir do filme de pó por raios $X$, foi calculado 0 $a_{0}$ (a zero), conforme anexo IV (AzAROFF et al., 1958).

Com $\circ a_{0}$ (a zero) igual a $11,596 \AA$ se determinou $\circ$ $\triangle 2 \theta$ igual a 8,09 , conforme Tabela 4 (2).

Os valores de propriedades físicas $\left(a_{0}, n\right.$ e $\left.D\right)$, que estão na Tabela 5, foram lançados em diagramas triangulares,conforme mētodo descrito por MADUREIRA FILHO (1972) e CAMARGO \& MADUREIRA FILHO (1976). Daí resultou a Tabela 6, (päg. 61) a partir da qual se calculou a composição correspondente. o resultado final da composição molecular è: almandina (64\%), piropo (19\%), espessartita (5\%) e grossulária (12\%). Existem indícios de campo de composição com espessartita, em vista de incipiente alteração para öxidos de manganês

\section{Pirita e pirrotita}

A pirita e pirrotita se apresentam de forma losangular, triangular e circular; enquanto a pirrotita também se apresenta em ripas de $0,012 \mathrm{~mm}$ de comprimento.

Ambos se encontram em percentagem inferior a 0,1

(Quadro 3).

\section{5 - TEXTURAS DEPOSICIONAIS}

\section{Textura em mosaico}

O gondito apresenta textura granoblästica em mosaico da granada em relação ao quartzo (Fotomicrografias 1 e 2).

A granada acha-se intensamente fraturada, enquanto o fraturamento do quartzo è menor (Fotomicrografia 1 ).

* A composição ternária foi transformada em composição quaternäria, confor me comunicação verbal de J.B.MADUREIRA FILHO (USP, 1979). 


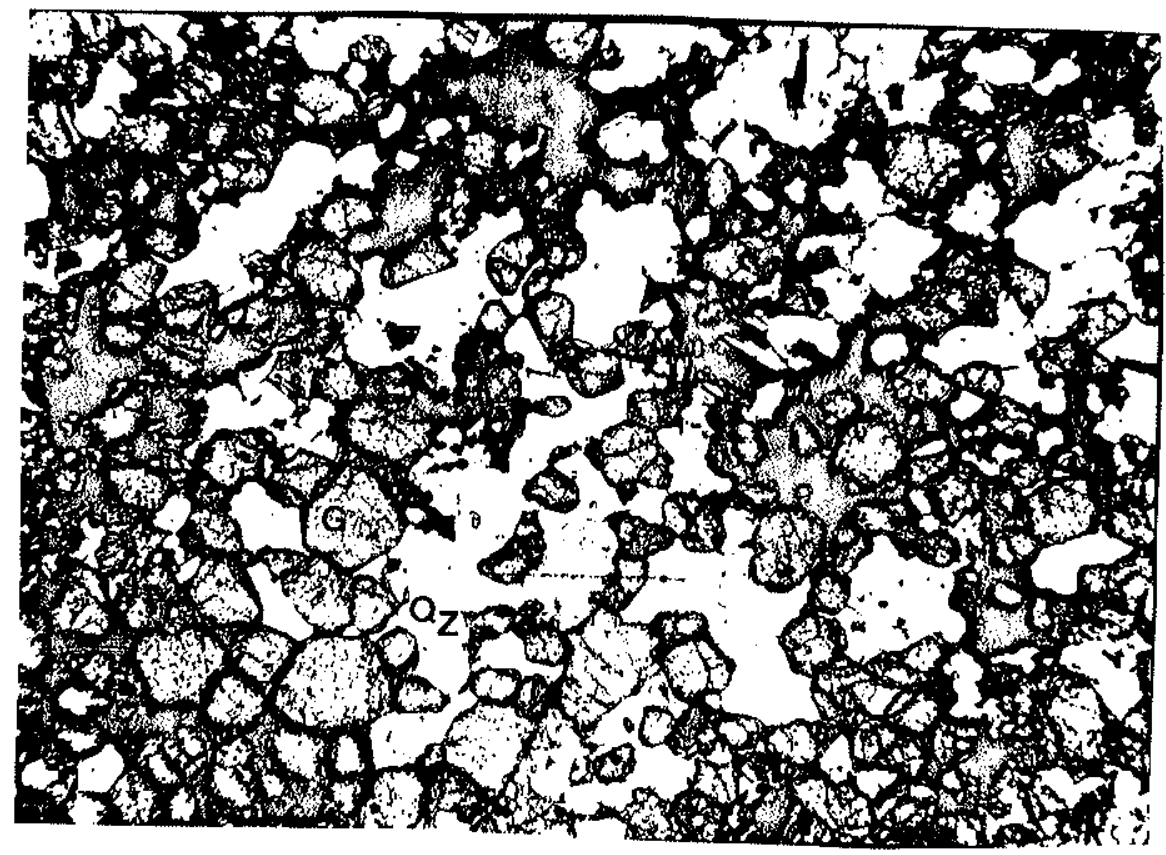

Fotomicrografia i - Lâmina delgada mostrando granada(g) predominante sobre quartzo ( $q z$ ) em textura em mosaico. Notam- se pequenas inclusões de quartzo na granada e grande fraturamento da granada. Nicóis paralelos; Aumento $27,5 \mathrm{x}$.

Existem algumas inclusões de quartzo dentro da granada e vice-versa (Fotomicrografia 1).

Os cristais de granada tem dimensões variāveis entre 0,012 e $0,60 \mathrm{~mm}$. No entanto, hā predominância de grãos de comprimento entre 0,12 e $0,24 \mathrm{~mm}$. A largura tem a mesma variação, sendo predominantes os grãos no intervalo entre $0,012 \mathrm{~mm}$ e $0,12 \mathrm{~mm}$.

o quartzo possui granulação um pouco maior $(0,8 \mathrm{~mm})$.

Textura de Limites Mütuos

Baseado no fato de que existem pequenos glóbulos e ripas $(0,2 \mathrm{~mm})$ de quartzo dentro da granada e na observação de que o contato entre o quartzo e a granada se dá em curvas suaves e regulares (sem reentrâncias de um em outro), conclui-se tratar-se de um caso típico de textura de limites mütuos (Fotomi- 


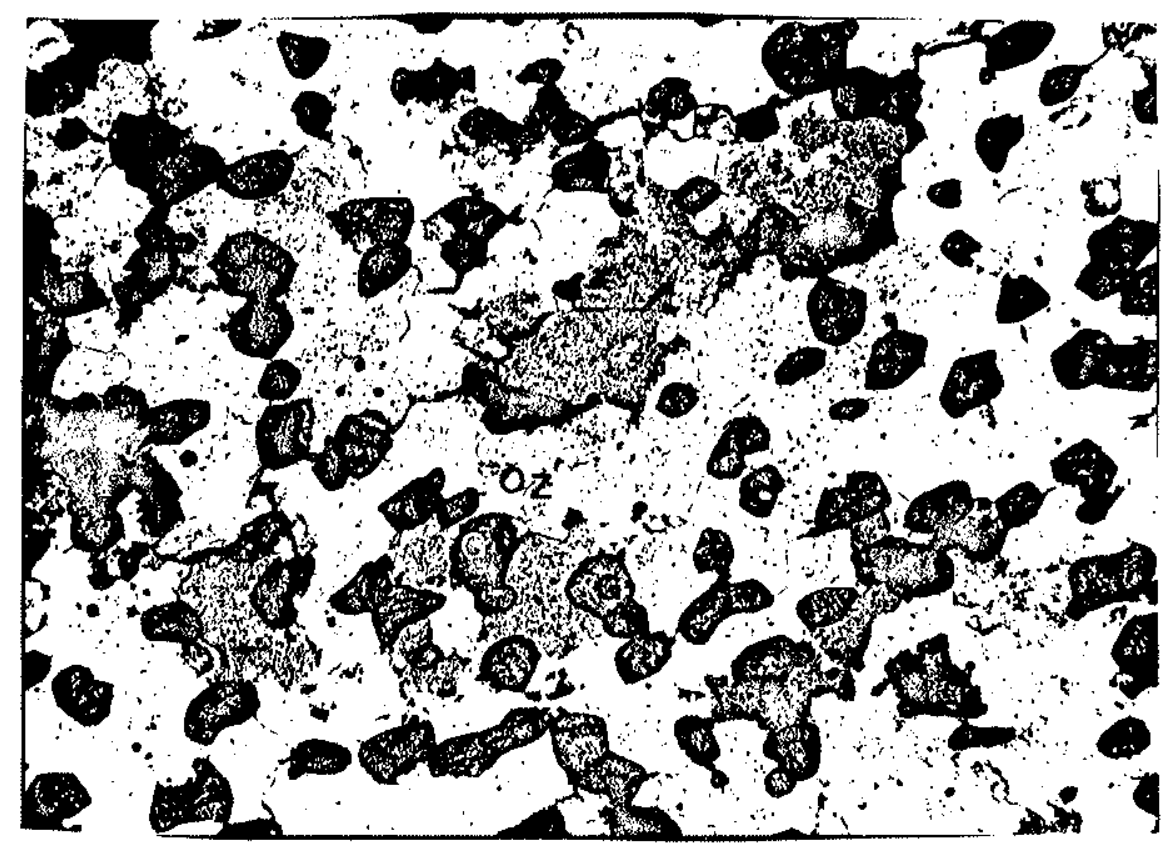

Fotomicrografia 2 - Lâmina delgada mostrando quartzo (qz) predominando sobre granada $(g)$ em textura em mosaico. observe-se pequenos glóbulos de quartzo dentro da granada que está distribuída conforme um dobramento sinclinal. Nicóis semi-cruzados; Aumento $27,5 \mathrm{x}$.

crografia 2). A ausência de projeção de um mineral em outro confirma este fato (SCHWARTZ, 1951).

\section{Textura Bandeada}

o quartzo e principalmente a granada ocorrem em camadas delgadas concordantes com o acamamento macroscópico da rocha (Fotomicrografia 3 ).

Os óxidos de manganês lamelares possuem seu maior comprimento paralelo a este bandeamento primário. 


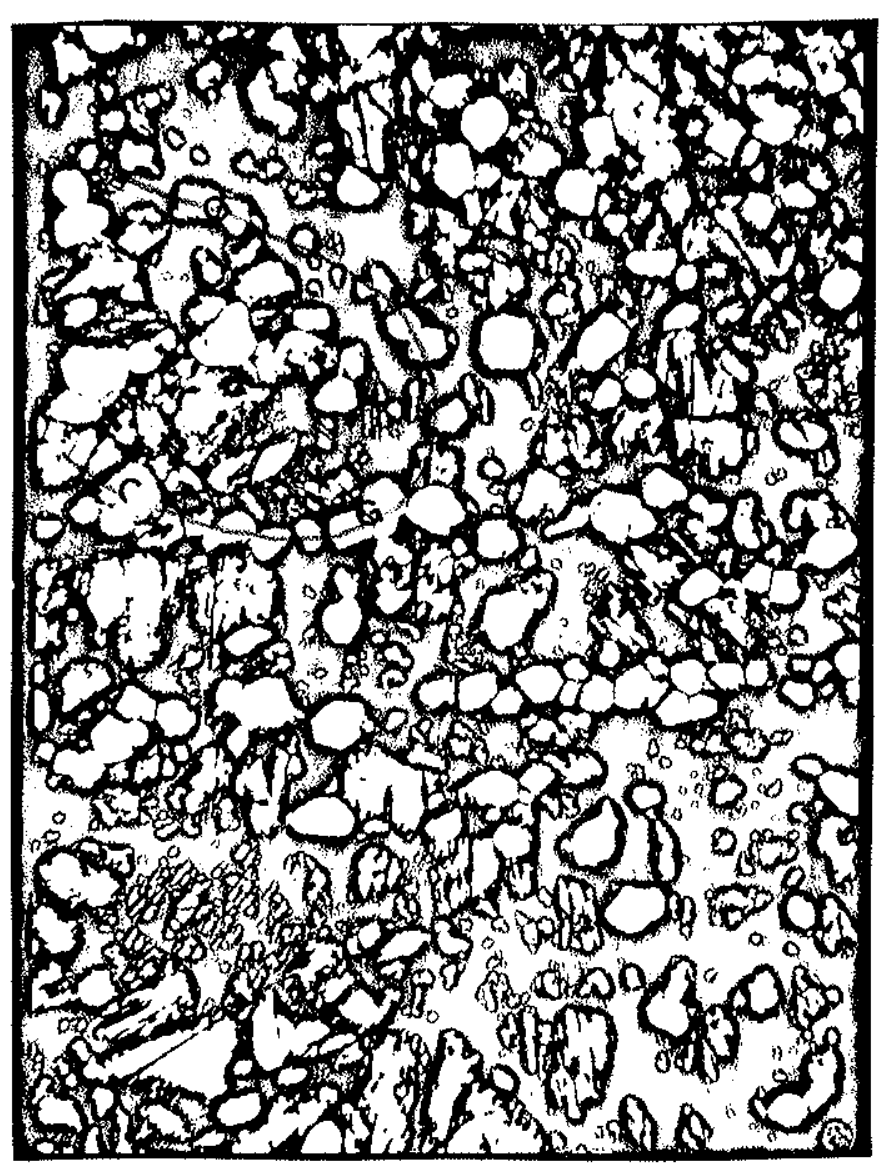

Fotomicrografia 3 - Lâmina delgada mostrando microdobramentos isoclinais que refletem os dobramentos maiores. Nicóis paralelos; Aumento $27,5 \mathrm{x}$.

Nota-se que o preenchimento de espaços por substâncias coloidais se dá paralelamente a este acamamento geral (Fotomicrografia 4).

- grau de variação de alteração em granadas produz um acamamento nitido. Comumente este bandeamento textural reflete o bandeamento estrutural do protominërio, que è constituỉdo por alternância de partes claras e escuras, refletindo um maior ou menor grau de intemperismo. 


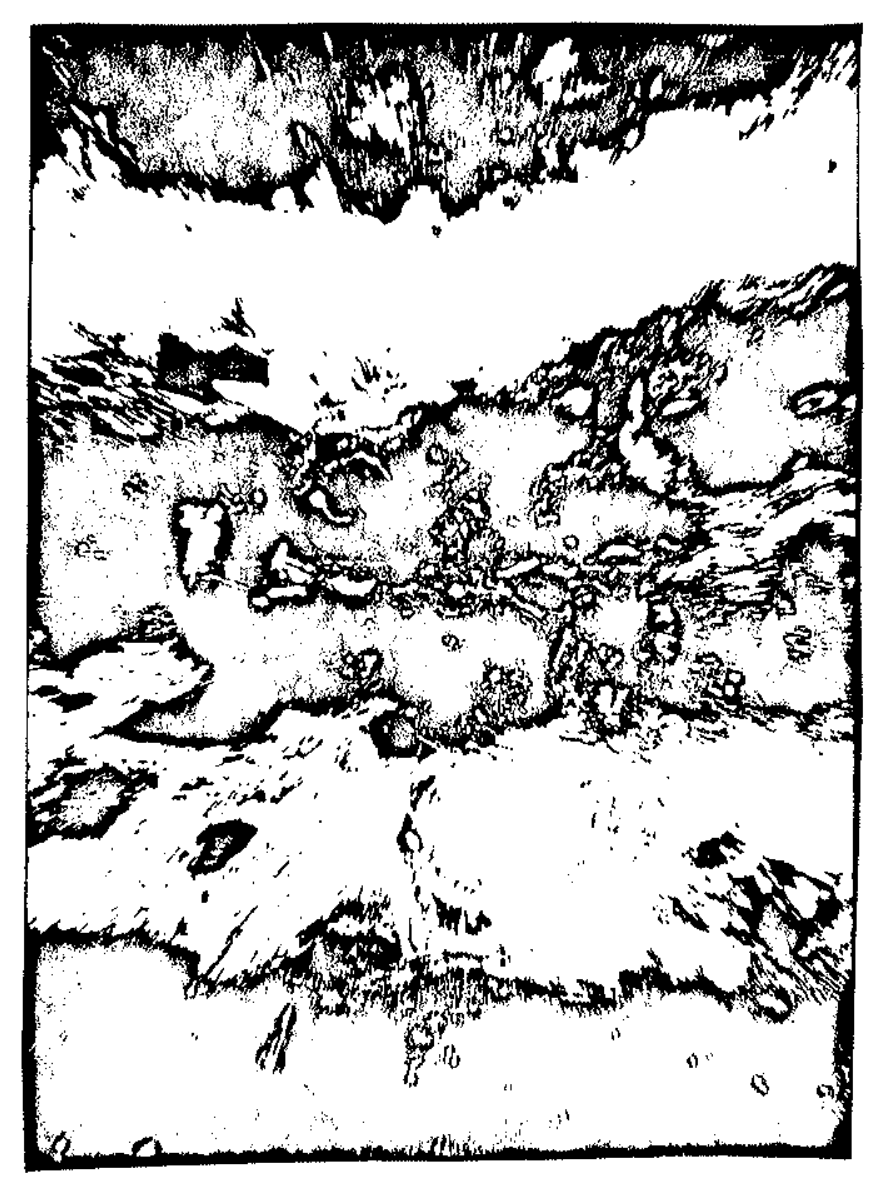

Fotomicrografia 4 - Superfície polida mostrando veios coloidais de óxidos de manganês (parte clara) concordantes com o acamamento geral. Nicóis paralelos; Aumento $32 \mathrm{x}$.

\section{Textura de Inclusão}

A pirita de diâmetro inferior a $0,012 \mathrm{~mm}$ se acha incluída nas granadas e preferencialmente nos cristais de quartzo.

Alguns cristais possuem forma circular e outros se apresentam em forma losangulares e triangulares.

A pirrotita tambëm se encontra incluída no quartzo e na granada, preferencialmente sob a forma de ripas de 0,012 mm de comprimento. 
São observadas agulhas de óxidos de manganês dentro do quartzo. Conforme RAMDOHR (1969) é comum haver agulhas de polianita dentro do quartzo em protominério de manganês.

\section{6 - CONDIÇÕES DE METAMORFISMO}

\section{6 .1 - ENCAIXANTES}

As rochas anteriormente descritas apresentam as seguintes associações minerais:

1 - Migmatito-gnaisse (Serragem, Lagoa do Riacho,Curupira e Morros)

Quartzo, biotita, silimanita, plagioclásio-An $28^{\prime}$ pertita, almandina, microclíneo e grafita.

2 - Biotita-quartzito (Serrote Cotas)

Quartzo-biotita e silimanita (rara).

3 - Granada-silimanita-quartzito (Serrote curupira)

Quartzo, biotita, almandina, silimanita (fibrolita) e plagioclásio.

4 - Metabasito (Morros)

Quartzo, biotita, hornblenda, ortopiroxênio, plagioclásio-An 48, microclíneo, ilmenita e magnetita.

5 - Metabasito (Morros)

Quartzo, ortopiroxênio, clinopiroxénio, oxtoclásio com exsoluções de albita, plagioclásio-An 45 , microclineo, ilmenita e magnetita.

6 - Migmatito básico (Morros)

Quartzo, biotita, hornblenda, oxtopiroxênio, clinopiroxênio, plagioclásio-An 45 , microclíneo e apatita.

7 - Pegmatito (Serragem, Lagoa do Riacho e Curupira) Biotita, quartzo, plagioclásio, microclíneo, pertita e grafita. 
8 - Hornblenda-xisto (Serrote Curupira)

Quartzo, hornblenda (verde oliva), almandina, apatita, ilmenita e magnetita.

9 - Granoblastito (Serrote Ocara)

(Granatito), quartzo, hornblenda (verde oliva), almandina, titanita e clorita secunaāria.

10 - Gnaisse-quartzo-feldspático - Quartzo, biotita, plagioclásio e almandina.

Notam-se nas associações, acima referidas, as seguintes feições: 1 - prevalência de almandina em associações quartzo-feldspäticas, 2 - presença de ortopiroxênio, clinopiroxênio junto com hornblenda, plagiocläsio, ortoclāsio e microclíneo em rochas bāsicas e 3 - ausência de outros silicatos calco-aluminosos. Estas características são típicas de metamorfismo de alto grau (WINKLER, 1976).

E importante notar a ausência de muscovita primāria. Esta ausência foi comprovada não sö por não ter sido encontrada a muscovita nas lâminas delgadas (critērio negativo), como também por tér sido constatadas as paragêneses de feldspato potãssico + silimanita e de feldspato potássico + almandina (critério positivo), resultantes da transformação de muscovita em altas pressões e em presença de quartzo e plagioclāsio (WINKLER, Op. Cit.).

A associação de felaspato potássico + quartzo + plagioclásio, juntamente com a paragênese de silimanita + almandina + biotita pertencem, segundo WINKLER (Op.Ci.t., pág. 91) ao setor de metamorfismo de alto grau (Figura 20). Estas paragêneses (1, 2 e 3) são características de regiões onde se encontram gnaisses peliticos. Neste ambiente, intercalações arenosas podem surgir como silimanita-quartzitos ( $n$ \% 3 ) entre gnaisses kinzigiticos (EBERT, 1968). 


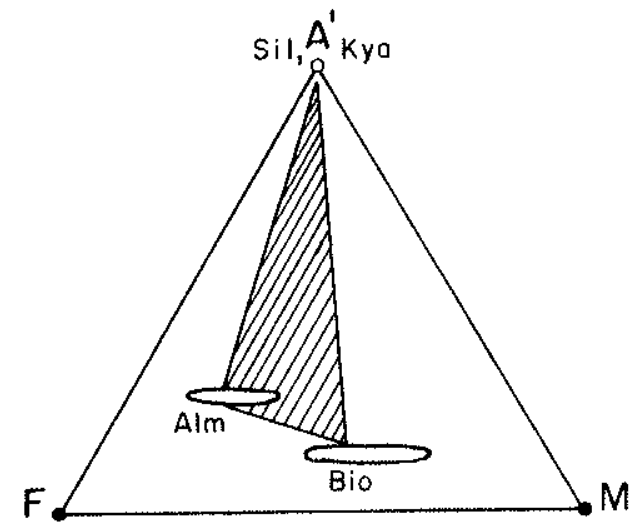

Figura 20 - Metamorfismo de pelitos. Setor de metamorfismo de alto grau, rico em almandina (WINKLER, 1976).

WINKLER (Op.Cit.) afirma que a almandina do gnaisse pelitico em metamorfismo de alto grau possui composição de 5,5 a 8\% de espessartita e 79 a $85 \%$ de almandina. Trabalhos de laboratörio com a almandina das associações nrs. 1 e 3 permitiram construir a Tabela 7 , a partir da qual se obteve a seguinte composição molecular: Almandina (72\%), piropo (26\%), grossulária (1\%) e espessartita (1응. Este fato indica que a espessartita entra em pequenissima percentagem. A composição química do silimanita-quartzito (Tabela 8) mostra que a percentagem em CaO $(0,70)$ é maior que a percentagem em Mno $(0,15)$.

MIYASHIRO (1973) afirma que o pequeno conteúdo em Mno e CaO nos metapelitos é indicativo de alto grau.

Todos os fatores anteriormente citados conduzem à conclusão de que as associações mineralögicas de números 1,2 e 3 são pertencentes ao metamorfismo de alto grau na fase rica em almandina e silimanita (Fotomicrografias 5 e 6 ).

Para determinar as condições mînimas de temperatura e pressão são utilizadas a relação FeO/Feo + Mgo e a ausência de cordierita no migmatito-gnaisse e no silimanita-quartzito. Estes dados são lançados na Figura 21 , de onde se concluem as condições de $P$ e $T$ (WINKLER, 1976). 


\section{TABELA 7}

PERCENTAGENS OBTIDAS A PARTIR DE DIAGRAMAS TRIANGULARES, SEGUNDO MÉTODO DE MADUREIRA FILHO (1972) E CAMARGO E MADUREIRA FILHO (1976) COMPLEMENTADAS EM DIAGRAMAS QUATERNARTOS CONFORME MADUREIRA FILHO (COMUN.TCAÇÃO VERBAL, 1979). (AMOSTRA 1, TABELA 5)

RESULTADOS DE DIAGRAMA TRIANGULAR

\begin{tabular}{l|ccc}
\hline GRUPO & $\mathrm{n}-\Delta 2 \theta\left(\frac{\mathrm{o}}{\mathrm{b}}\right)$ & $\Delta 2 \theta-\mathrm{D}$ & $\mathrm{D}-\mathrm{n}$ \\
\hline 1 & Alm. -74 & Alm. -53 & Alm. -30 \\
& Pir. -25 & Pir. -44 & Pir. -40 \\
& And. -1 & And. -3 & And. -30 \\
\hline
\end{tabular}

RESULTADOS DE DIAGRAMA QUATERNARTO

$$
\begin{aligned}
& \text { Alm. - } 64 \% \\
& \text { Pir. - } 19 \% \\
& \text { Esp. - } 5 \% \\
& \text { Gr. - } 12 \%
\end{aligned}
$$


TABELA 8

ANĂLISES QUIMICAS REALIZADAS PELO LABORATORIO PURIQUIMA S/A E PELO LABORATÓRIO DE QUIMICA DO DEPARTAMENTO DE MINERALOGIA E PETROGRAFIA DO INSTITUTO DE GEOCIENCIAS DA USP. (\% EM PESO)

$\begin{array}{llllllll}\mathrm{ROCHA} & \mathrm{SiO}_{2} & \mathrm{TiO}_{2} & \mathrm{Fe}_{2} \mathrm{O}_{3} & \mathrm{FeO} & \mathrm{MgO} & \mathrm{CaO} & \mathrm{Mn}\end{array}$

$\begin{array}{llllllll}\begin{array}{l}\text { Migmatito } \\ \text { gnaisse }\end{array} & 68,10 & 0,68 & 1,69 & 6,28 & 2,65 & 1,18 & - \\ & & & & & & & \\ \begin{array}{l}\text { Silimanita } \\ \text { quartzito }\end{array} & 81,79 & 0,29 & 1,23 & 5,51 & 0,90 & 0,70 & 0,15 \\ & 27,57 & 0,17 & 0,60 & - & - & - & 49,48\end{array}$

(a) não foi dosado $\mathrm{Al}_{2} \mathrm{O}_{3}$. 
A relação Feo/Feo + Mgo (conforme Tabela 8) para as associações de números 1 e 3 são as seguintes:

Para associação n! 1 (migmatito-gnaisse):

$\frac{\mathrm{FeO}}{\mathrm{FeO}+\mathrm{MgO}}=\frac{6,28}{6,28+2,65}=\frac{6,28}{8,93}=0,70$

Para associação no 3 (silimanita-quartzito):

$\frac{\mathrm{FeO}}{\mathrm{FeO}+\mathrm{MgO}}=\frac{5,51}{5,51+0,90}=\frac{5,51}{6,41}=\underline{0,85}$

Estas relações (A e B) quando lançadas na Figura 21 (WINKLER, 1976) dä uma pressão mínima aproximada de $6 \mathrm{~kb}$ para $\circ$ metamorfismo acima considerado.

Esta pressão $(6 \mathrm{~kb})$ pressupõe uma espessura minima de 21 a $22 \mathrm{~km}$ da crosta continental no tempo do metamorfismo (WINKLER, op.Cit.). Nestas condições de alta pressão de carga, é de se esperar que o conteúdo em Mno da almandina e das rochas pelíticas seja pequeno, principalmente quando a pressão de água ( $\mathrm{P} \mathrm{H}_{2} \mathrm{O}$ ) é infima (MIYASHIRO, 1973).

Esta pressão mínima de $6 \mathrm{~kb}$ concorda com a presença de silimanita na paragênese que indica pressão média a alta.

o intervalo de temperatura não foi precisado, mas pela Figura 21 a temperatura minima é estimada em $600^{\circ} \mathrm{C}$.

A paragênese hornblenda + biotita, presente no metabasito de associação nrs 4 e 6 , desaparece no mesmo metabasito de associação no 5. Este fato se deve à mudança de teor de $\mathrm{CO}_{2}$ e $\mathrm{H}_{2} \mathrm{O}$ na fase fluida.

A associação biotita + hornblenda presumivelmente existente na rocha ignea sofreu transformação em ortopiroxênio + clinopiroxênio, em virtude de o metamorfismo progressivo regional retirar água $\left(\mathrm{H}_{2} \mathrm{O}\right)$ da fase fluida. Nesta caso pode ter sido formado 


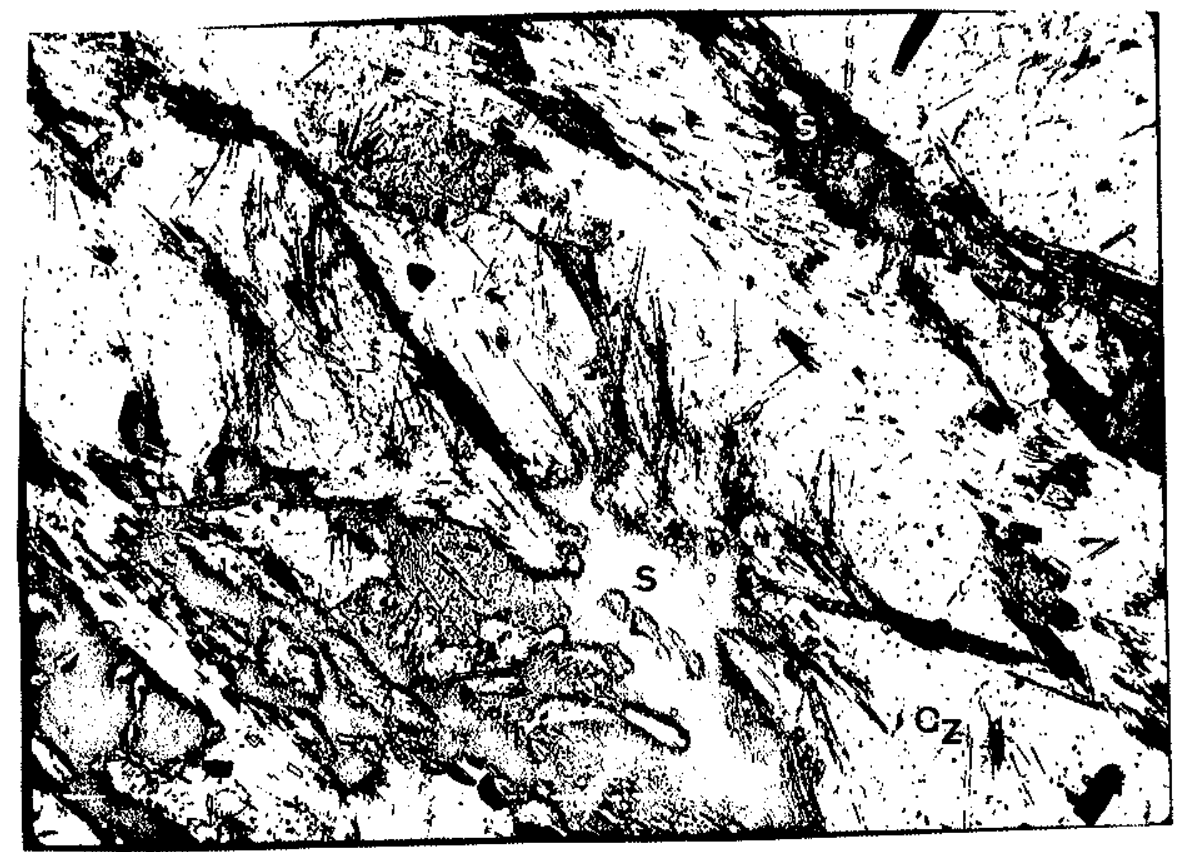

Fotomicrografia 5 - Lâmina delgada mostrando silimanita

(s) e quartzo(qz) no quartzito que aflora no serrote Curupira(Aracoiaba-CE). Nicóis semi-cruzados; Aumento $50 \mathrm{x}$.

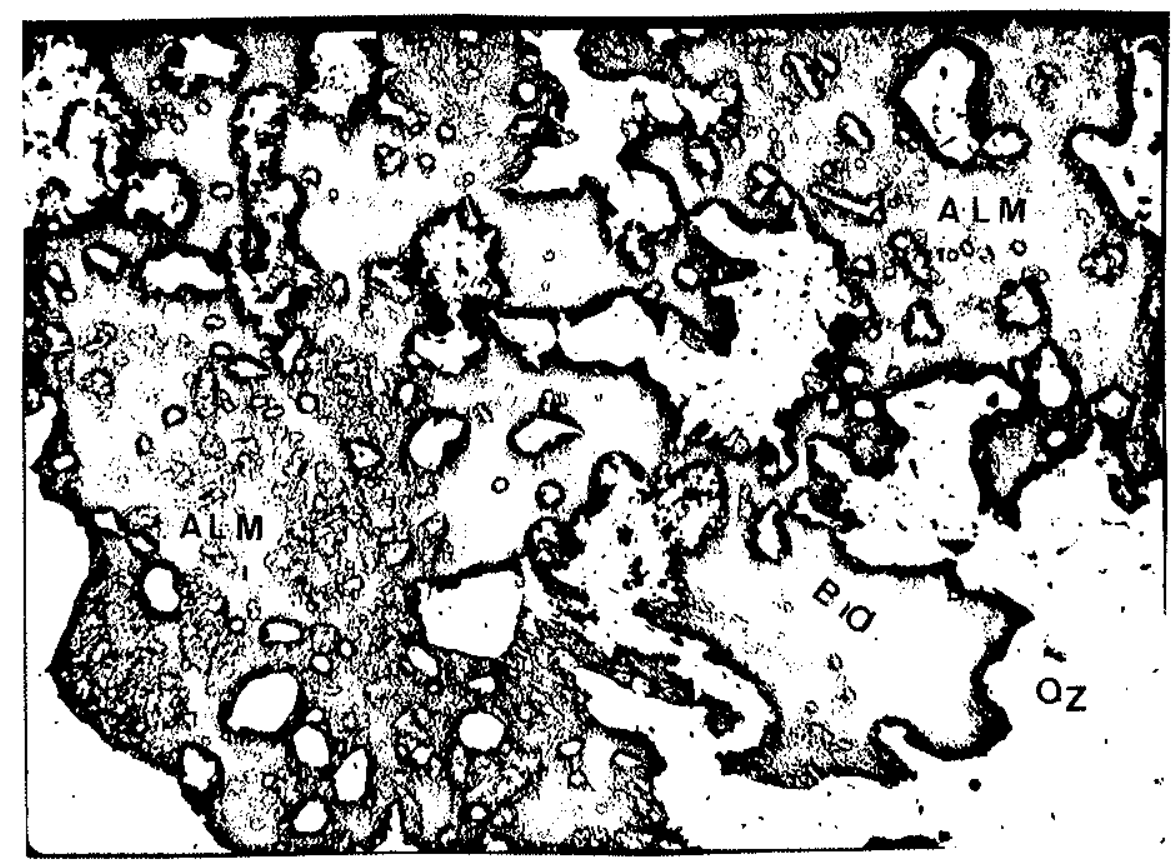

Fotomicrografia 6 - Lâmina delgada mostrando almandina (alm), quartzo(qz) e biotita(bio) no migmatito-gnaisse que aflora no serrote Pelado. Nicóis cruzados; Aumento $50 \mathrm{x}$. 


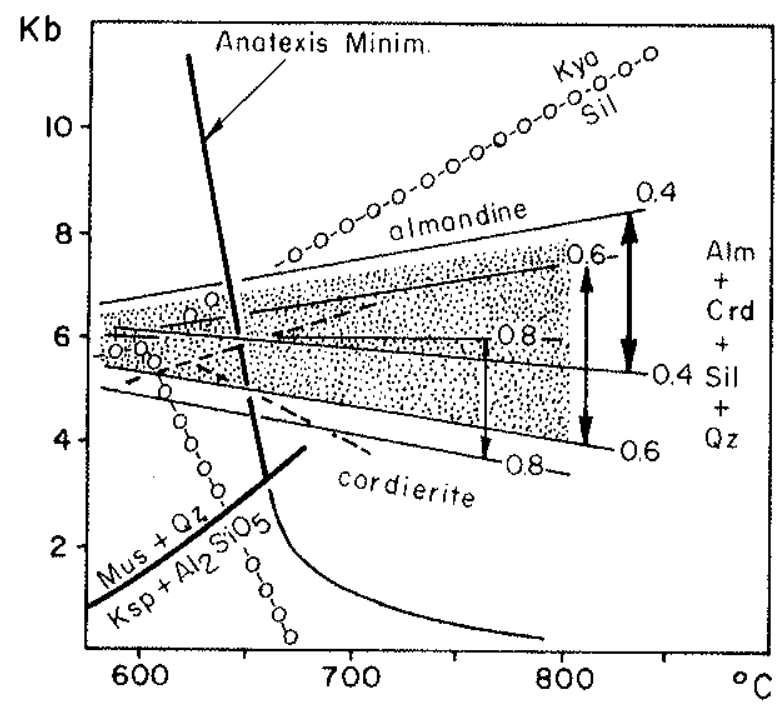

Figura 21 - Lançamento da relação $\mathrm{FeO} / \mathrm{FeO}+\mathrm{MgO}$ que é igual a 0,7 e 0,85 para o migmatito-gnaisse e para o silimanita quartzito respetivamente. Neste caso, a pressão tem um valor mínimo de $6 \mathrm{~kb}$, considerando que não se observa cordierita na paragênese. Por este diagrama é estimada uma temperatura minima de $600^{\circ} \mathrm{C}$. 
- ortocläsio com exsoluções de albita, originando a associação no 5 (Fotomicrografia 7).

Em um segundo estágio, com o aumento da pressão de ăgua $\left(\mathrm{P} \mathrm{H}_{2} \mathrm{O}\right)$ na fase fluida, o clinopiroxênio e ortopiroxênio se transformaram em hornblenda que é vista atualmente contornando o clinopiroxênio e ortopiroxênio. Este fato configura a fácies anfibolítica que está se superpondo à fácies granulítica,em uma fase posterior.

Segundo De WAARD (Op.Cit.), a reação hornblenda + + biotita + quartzo dando ortopiroxênio + feldspato potássico + plagioclásio $+\mathrm{H}_{2} \mathrm{O}$, que ocorre em rochas máficas, representa a diminuição ou desaparecimento de hornblenda + biotita; e é um diagnöstico de existência de condições metamōrficas de fácies granulitica num primeiro estágio.

Frisa-se o fato de que não foi observada granada no metabasito. Justifica-se isto em razão de a composição ser muito cálcica (De WAARD, 1965).

Nos gnaisses peliticos, nestas mesmas condições metamōrficas, ocorre a seguinte reação: biotita + silimanita + tquartzo $=$ almandina+feldspato potássico $+\mathrm{H}_{2} \mathrm{O}$ (WINKLER, Op. cit.).

Deste modo, as associações do metabasito com as paragêneses de hornblenda + ortopiroxênio e/ou clinopiroxênio ( 4 e 6) e de ortopiroxênio + clinopiroxênio + plagioclásio atestam a existência de fácies granulito.

Conforme as observações em De WAARD (1965), as associações 4, 5 e 6, representam duas sub-fäcies da fäcies granulito: a primeira se caracteriza pela paragênese hornblenda + ortopiroxênio + plagioclásio $(4$ e 6$)$, e a segunda se caracteriza pela paragênese ortopiroxênio + plagioclásio (5).

As associações I e 9 que ocorrem em serragem, Lagoa do Riacho e Curupira são iguais, em condições metamórficas, às associações 4, 5 e 6, que ocorrem em Morros (Chorozinho). O migmatito-gnaisse (1) de Serragem, Lagoa do Riacho e Curupira é o 


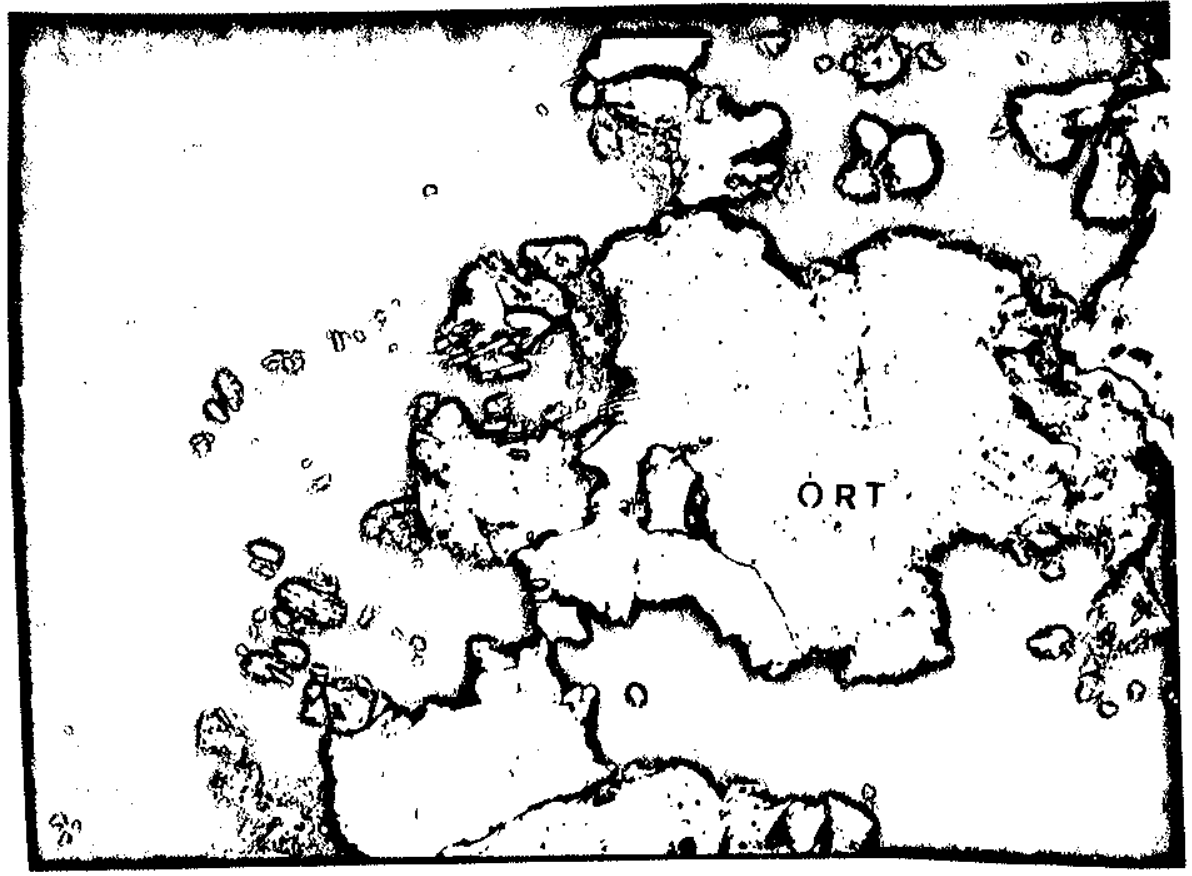

Fotomicrografia 7 - Lâmina delgada mostrando ortoclāsio(ort) com exsolução de albita(alb) no metabasito. Nicóis cruzados;Aumento $107 \mathrm{x}$. 
mesmo que ocorre em Fiúza e Morros. A diferenciação litológica está no fato de que em Morxos não existe a rocha de associação 3 (silimanita-quartzito), enquanto em Serragem, Lagoa do Riacho e Curupira não foram encontrados metabasitos $(4,5 \mathrm{e} 6)$.

Nas associações 1 e 9 a pressão de ãgua é provave1mente mais alta do que nas outras. Isto influi na diferença de mineralogia entre os dois conjuntos de rochas.

Na associação 9, a hornblenda de cor verde oliva indica alto grau de metamorfismo (WINKLER, Op.Cit.).

Pelas considerações anteriores, as condições de $\mathrm{P}$ e T são iguais em ambas as partes, mudando apenas ligeiramente a percentagem de $\mathrm{CO}_{2}$ e $\mathrm{H}_{2} \mathrm{O}$ na fase fluida.

Em resumo, pelos dados acima referidos, pode-se afirmar que as condições de metamorfismo da área são iguais em curupira, Serragem e Lagoa do Riacho (Aracoiaba) e Morros (Chorozinho), mesmo porque todas as rochas estão no mesmo nivel estratigräfico.

Pelos dados de campo não se pode conjecturar sobre presumiveis condições anatéxicas jā que o prōprio gnaisse que teve denominação descritiva de campo de "migmatito estromatítico" pode ser, na realidade, somente um gnaisse formado por diferenciação metamórfica.

Em representação điagramätica triangular (Figura as associações 4,5 e 6 se enquadram nos domínios abrangidos pelos números 4,5 e 6 (WINKLER, 1976).

o primeiro estágio de metamorfismo progressivo produziu as paragêneses de granolitos com clinopiroxênio e ortopiroxênio, com idade mínima de $2.100 \mathrm{~m} . \mathrm{a}$. e a uma profundidade aproximada de $22 \mathrm{~km}$. No segundo estágio de metamorfismo com acesso de ăgua e a uma profundidade menor, o piroxênio se transforma em hornblenda em condições de fäcies anfibolítica, com idade mínima de $600 \mathrm{~m} . \mathrm{a}$. , demonstrando que houve uma remobilização durante o ciclo brasiliano de minerais formados no ciclo transamazônico. 


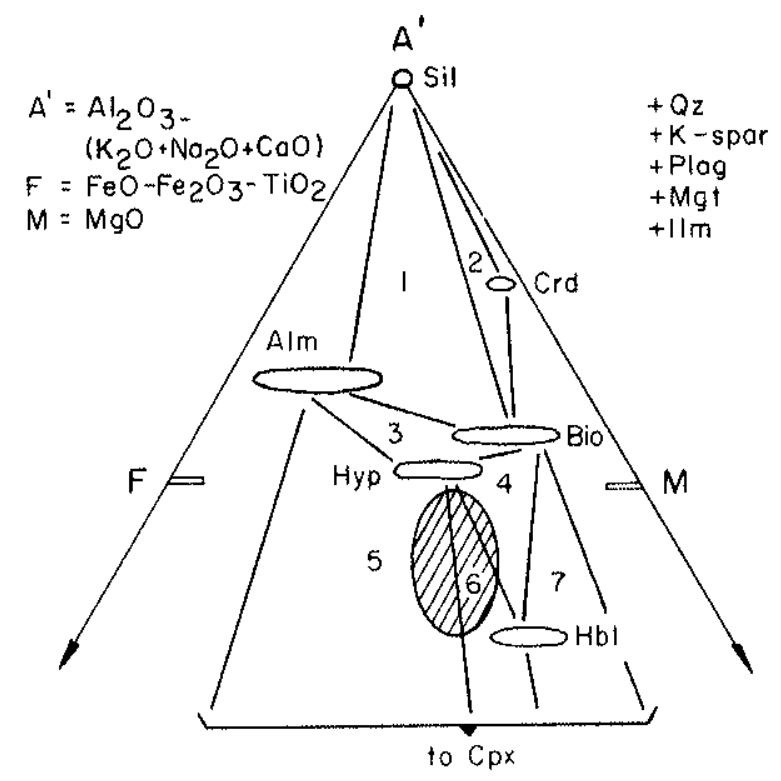

Figura 22 - Parte hachuriada delimitando os domínios das associações 4,5 e 6 (pāg.67) em granoblásticos. (Segundo WINKLER, 1976).

\section{$7.6 .2-$ GONDITO}

Na ārea de Serragem e Lagoa do Riacho são encontradas as seguintes associações mineralógicas em gondito:

1 - Quartzo - espessartita - mangano-cumingtonita

2 - Quartzo - espessartita - mangano-cumingtonita rodonita - titanita-pirofanita - grafita e pirita - pirrotita.

o gondito, juntamente com granada-quartzito, está encaixado no gnaisse pelítico (migmatito-gnaisse - Associação 1) em que, por sua vez, se acham encaixados os metabasitos (Associações 4,5 e 6 ).

Deste modo, quanto às condições metamórficas, o gondito se insere no contexto descrito no item anterior (7.6.1).

Neste item, serão discutidos, apenas, alguns aspec- 


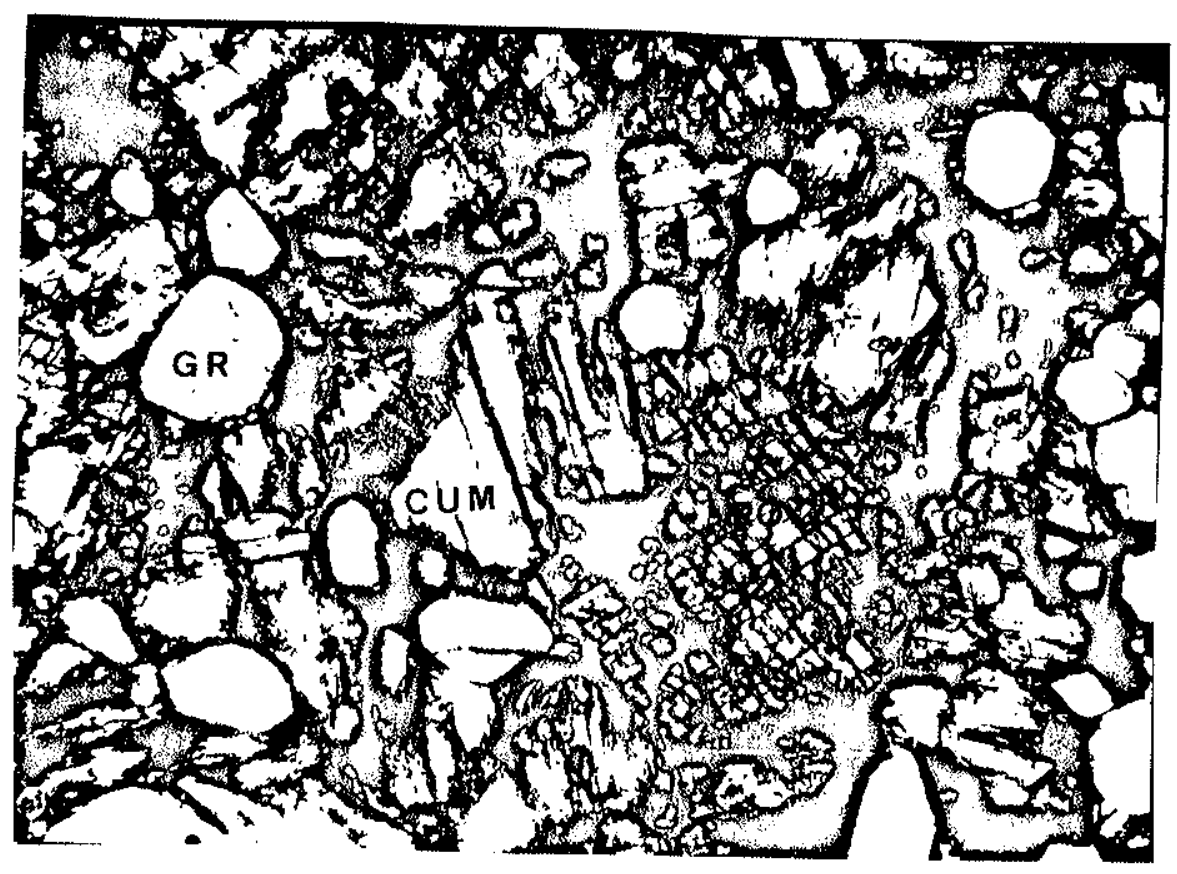

Fotomicrografia 8 - Lâmina delgada de gondito alterado mostrando granada $(g r)$, rodonita(ro) e mangano-cumingtonita (cum). Nicöis paralelos; Aumento $72 \mathrm{x}$.

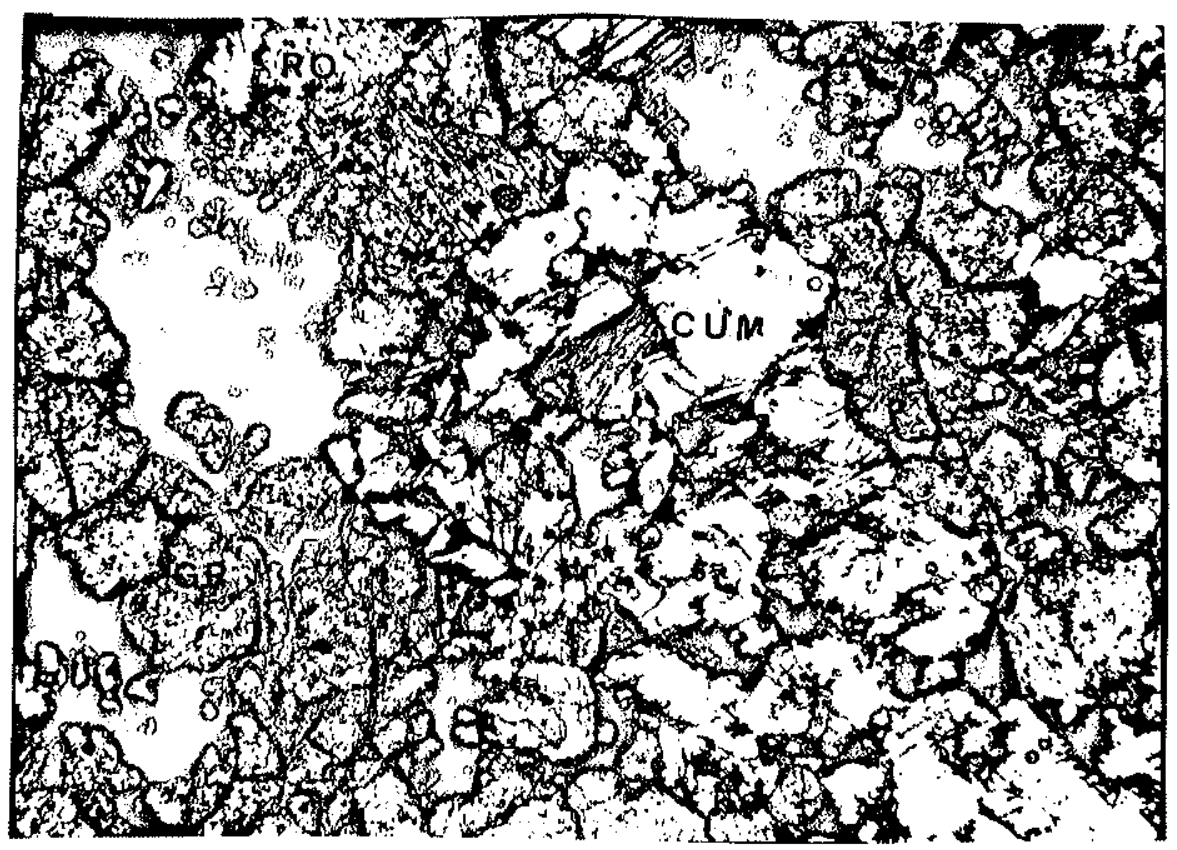

Fotomicrografia 9 - Lâmina delgada de gondito alterado mostrando granada $(g r)$, rodonita (ro) e mangano-cumingtonita (cum). Nicóis cruzados; Aumento $27 \mathrm{X}$. 
tos da associação mineral do gondito.

O manganês se combina com alumina e sîlica para formar espessartita; o excesso de silica permanece em forma de quartzo.

A formação do tipo de piroxenóide depende da relação $\mathrm{Mn} / \mathrm{Ca}$ (ABRECHT et al., 1975), e da temperatura (PETERS et al., 1974) e (BELLO, 1978), conforme mostra a Figura 23.

Em temperaturas mais altas, os piroxenóides admitem mais $\mathrm{Mn}, \mathrm{Fe}$ e Mg do que $\mathrm{Ca}$, o que contribui para o aumento da relação Mn/Ca (BELLO, Op.Cit.). Daí decorre a compatibilidade da existência de piroxmangita e/ou rodonita, que são mais ricas em Mn do que em Ca. Entretanto, devido a alta temperatura de formação (acima de $600^{\circ} \mathrm{C}$ ) se formou apenas a rodonita.

E provável que em temperatura mais baixa $\left(<600^{\circ} \mathrm{C}\right)$ tenha se formado a piroxmangita; posteriormente, no metamorfismo regional progressivo tenha se transformado em rodonita (Figura 23). Experiências de laboratório atestam que o inverso não ocorre,conforme ABRECHT et al. (Op.Cit.).

A paragênese 11 e 12 do gondito admite a existência primária de uma fase carbonática (KRUMBEIN \& GARRELS, 1952). Entretanto, conforme ROY (1965) em temperaturas de alto grau a associação espessartita + rodonita + rodocrosita não se formam em equilíbrio estável. A rodonita e rodocrosita se combinam para formar tefroita. Como não foi encontrada tefroita na associação de Serragem e Lagoa do Riacho, presume-se que a fase carbonātica, por ser pouco abundante e espessa, foi parcialmente consumida na formação de espessartita numa primeira etapa; e numa segunda etapa, tendo em vista a abundância de quartzo na associação, a fase carbonática remanescente se transforma totalmente em rodonita em vez de, parcialmente, em tefroita. BITTENCOURT (1973)afirma que, em Morro de Mina (MG) quando a camada de carbonato original era pouco espessa, o carbonato foi totalmente substituído por espessartita.

A mangano-cumingtonita é um anfibólio, no qual o man- 


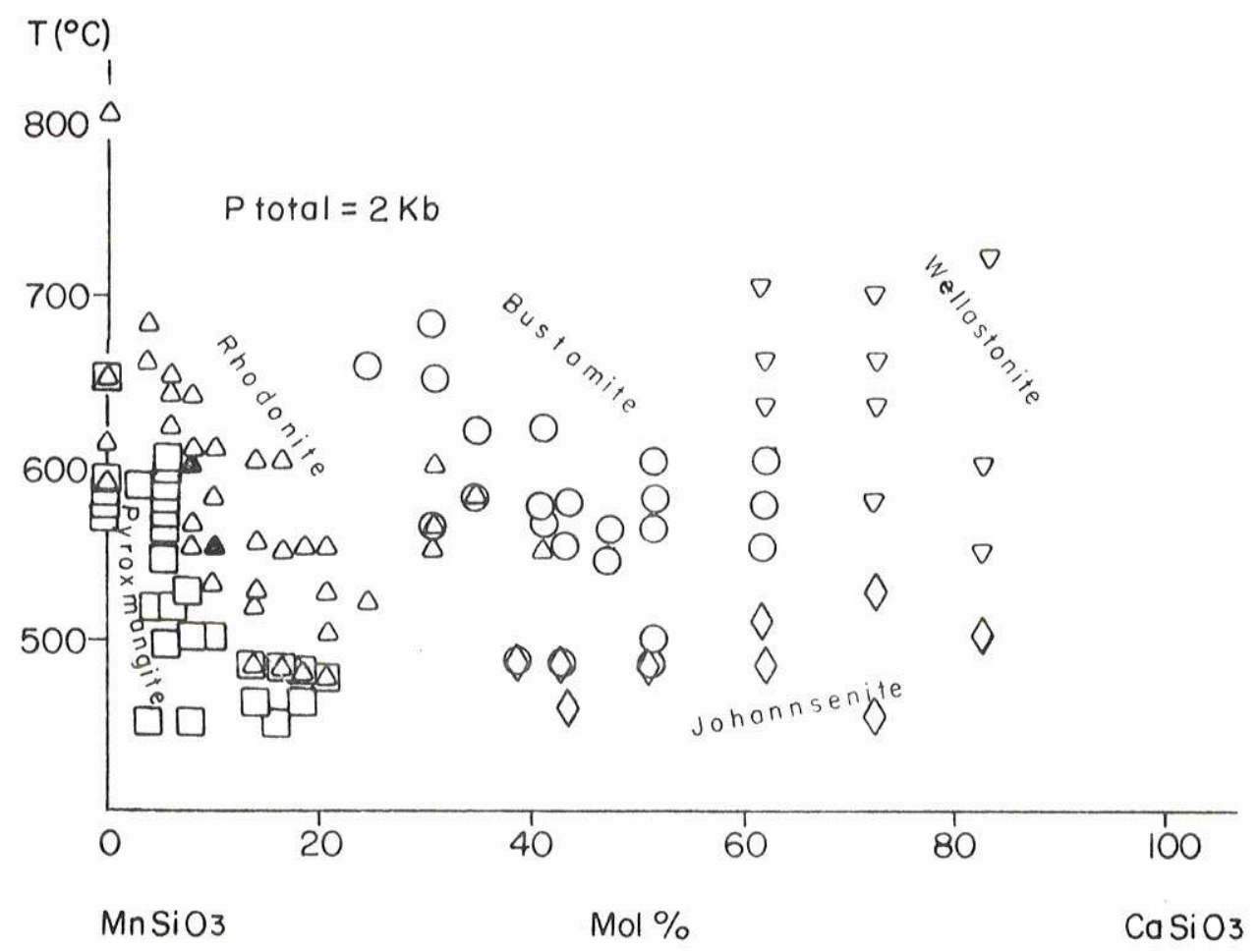

Figura 23 - Resultados experimentais que mostram a influência da relação $\mathrm{Mn} / \mathrm{Ca}$ e da temperatura na formação do tipo de piroxenóide. (ABRECHT et al.1975).

$$
\begin{aligned}
& \square \text { - Piroxmangita } \\
& \Delta \text { - Rodonita } \\
& \circ \text { - Bustamita } \\
& \nabla \text { - Wolastonita } \\
& \Delta \text { - Johansenita }
\end{aligned}
$$


ganês substitui o în ferroso (CHAKRABORTY, 1963), e se forma onde a pressão parcial de ãgua foi alta (BELLO, 1978). Em vista disso, sugere-se que a mangano-cumingtonita do gondito é um produto de retrometamorfismo. COUTINHO et al. (1978) cita este fenômeno para alguns protominérios sỉlico-carbonáticos do Brasil.

A identificaçăo de fácies anfibolito em um segundo estăgio de metamorfismo nas rochas encaixantes sugere outra idéia de que a mangano-cumingtonita seja um produto de metamorfismo progressivo, tendo em vista que em condições de fácies anfibolītica a pressão parcial de ãgua é mais alta, permitindo sua formação no metamorfismo progressivo.

A partir da associação mineral de espessartita + mangano-cumingtonita + rodonita se depreende que o gondito é mais rico em $\mathrm{MnO}, \mathrm{SiO}_{2}$ e Mgo do que em FeO; O FeO, por outro lado, é mais abundante em reação ao $\mathrm{CaO}$, liberado pela fase carbonática.

\section{$7.7-$ ESTRUTURA}

Nas rochas encaixantes e no gondito se observa um acamamento que coincide com a foliação.

A foliação do gondito tem direção geral N10 $\mathrm{W}$ e mergulho de $75^{\circ}$ para leste. Nas referências bibliográficas atinentes à região não se encontra nenhuma argumentação a favor do paralelismo entre a foliação e o acamamento original; entretanto, este fato é aceito sem dúvidas.

o acamamento original é dificil de ser encontrado, tendo em vista que se trata de rochas policiclicas e muito intemperizadas.

Algumas observações de campo e de laboratório indicam que o acamamento original é coincidente com a foliação. São as seguintes:

A - Preenchimento de veios de quartzo na direção para- 
lela à foliação. Entretanto, è difícil distinguir se um veio pertence ao primeiro evento de metamorfismo que atuou diretamente sobre as rochas sedimentares.

B -Em observação mesoscōpica, nota-se que as linhas de contato entre as rochas são sempre paralelas à foliação.

C -A variação de espessura e a relativa extensão longitudinal das lentes de quartzito são indicativos de feição sedimentar remanescente e näo de bandeamento metamōrfico (HöREN, 1953).

D -No migmatito-gnaisse e no quartzito se observa, mesoscopicamente, um acamamento que não se reflete microscopicamente na orientação dos grãos. Isto indica que o acamamento observado é herdado da rocha sedimentar original.

E - Regionalmente observa-se um nitido aumento no tamanho dos grãos, a partir do migmatito-gnaisse de granulação grosseira (Base do perfil vertical) até - granada-quartzito e gondito (Topo do perfil vertical) de granulação fina. Esta variação de granulação nas rochas metamóxficas, submetidas às mesmas condições metamörficas, ē provavelmente herdada da sedimentação gradual que se processou na formação de rochas sedimentares.

Nesta linha de raciocínio, infere-se (posteriormente) que o gondito ocupa o topo da sequência gradual.

F -Em depósitos de manganês, normalmente há uma gradação e alternância de sedimentos ricos em ferro e sedimentos ricos em manganês (KRAUSKOPF, 1957). Isto é observado claramente na região, com a gradação e alternância de migmatito e quartzito com almandina (rica em ferro) e gondito com espessartita (rico em manganês). 
G - Observam-se interacamamentos e concordâncias do gondito com os estratos de migmatito-gnaisse e quartzitos, mesmo quando altamente dobrados (Perfis $\mathrm{AB}$ e $\mathrm{A}^{\prime} \mathrm{B}^{\prime}$, päg. 39 e 41 ).

Pelo Mapa de Localização de Ocorrências (pág. 8) observam-se os depósitos de manganês alinhados na direção $\mathrm{N} 10^{\circ} \mathrm{E}$ e N2 $0^{\circ}$ E. Todavia, na descrição de cada depósito se observa uma direção geral $N 10^{\circ} \mathrm{W}$ e mergulho de $50^{\circ}$ a $75^{\circ}$ para leste. Esta fato indica que as camadas estão dobradas ao longo da direção geral do alinhamento regional dos depósitos.

Este alinhamento regional,por sua vez, faz um ângulo de $15^{\circ}$ com a falha transcorrente de Senador Pompeu (Vide Mapa Estrutural, pāg. 32). Esta direção coincide com a orientação de eixos de dobramentos secundārios de segunda ordem, resultantes da compressão primāria, conforme modelo regmático explicado em item anterior.

Em resumo, os fatos expostos anteriormente, indicam que existem sinclinais, cujos flancos de direção $\mathrm{N} 10^{\circ} \mathrm{E}$ e $\mathrm{N} 20^{\circ} \mathrm{E}$ estão dobrados ao longo de seu comprimento formando pequenas dobras secunaārias cujos flancos têm direção $N 10^{\circ} \mathrm{W}$ a $N 20^{\circ} \mathrm{W}$. o protominērio de manganês ocupando o topo da sequência gradual, situa-se no núcleo de dobras sinclinais pertencentes aos dobramentos secundários (Foto 5), cujos eixos estão aproximadamente paralelos ao eixo da dobra sinclinal representado pelo serrote de ocara com plunge para SE e que sofreu deslocamentos devido a falhas transcorrentes.

A Figura 17 (păg.53) representa uma dobra sinclinal reversa onde o flanco oeste preserva a ordem estratigräfica normal da área.

7.8 - AMBIENTE DE DEPOSIÇÃO DE MINERAIS

Os sedimentos originais eram provavelmente rochas ar- 
gilosas e calcárias, arenitos ricos em manganês e arenitos ricos em ferro. Estas rochas, submetidas a metamorfismo de alto grau, se transformam em hornblenda-xisto, gnaisse, migmatitos, quartzitos comuns e gonditos.

DORR et al. (1956) conclui que os sedimentos originais em Conselheiro Lafayete (MG) foram depositados em ambientes euxinicos, onde $\circ \mathrm{pH}$ e igual a 7 e o Eh igual a - 0,30 V. EBERT (1963), estudando o mesmo depósito, sugere que tenha havido ambiente redutor, devido às presenças de grafita e pirita.

De acordo com as conclusões de DORR (Op.Cit.)e EBERT (Op.Cit.) em relação aos depósitos de Conselheiro Lafayete, a paragênese de pirita e grafita em Aracoiaba-Pacajüs (CE) indica um ambiente euxínico de deposição, em condições redutoras em que se pressupõem valores de $\mathrm{pH}$ e Eh entre 7 e 8 e $-0,3$ e $-0,2 \mathrm{~V}$ respectivamente (Figura 24).

Em função das altas percentagens de material carbonoso, a pirita pode ser originada por meio da redução de sulfato de Fe.

Neste ambiente se justifica a presença de carbonato de manganês no depósito primārio. Conforme DORR (1968) os carbonatos são depositados em bacias restritas.

De acordo com os comentários anteriores, os minerais primários presumivelmente existentes no depósito original de Aracoiaba-Pacajús (CE) são carbonatos de manganês, quartzo, outros silicatos e sulfetos. Os carbonatos, no entanto, constituem lentes de rochas sedimentares pouco espessas e pouco abundantes. Isto é inferido a partir da pouca quantidade de rodonita e da ausência de piroxmangita e tefroita.

Em resumo, coloca-se a fácies de deposição original dos sedimentos que formaram o gondito em posição intermediária entre a zona de carbonatos e a zona de sulfetos do diagrama construído por KRUMBEIN \& GARRELS (1952) (Figura 24).

No momento, não se dispõe de dados para se fazer uma 


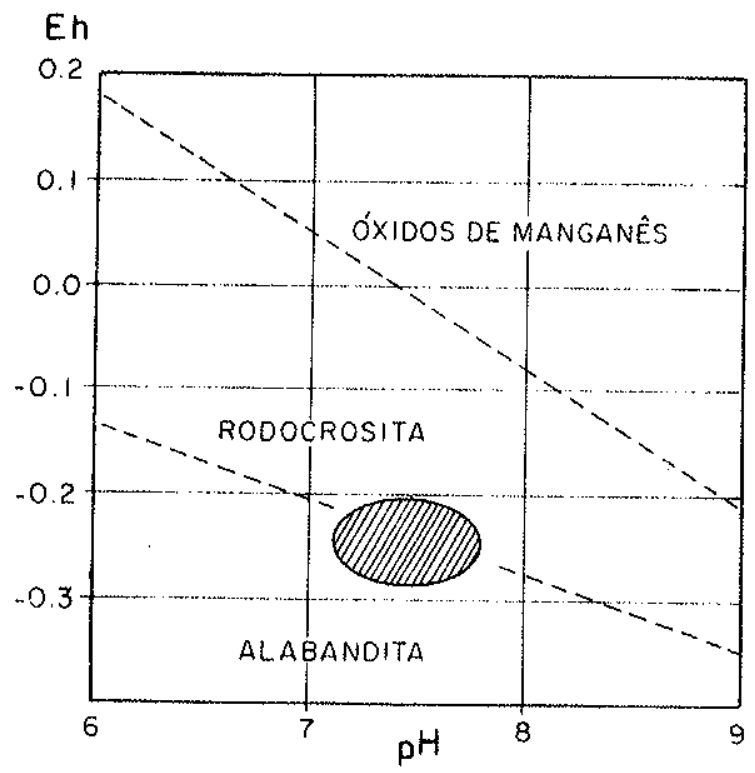

Figura 24 - Diagrama Eh-pH para o manganês, mostrando os campos de estabilidade de óxidos, carbonatos e sulfetos (KRUMBEIN \& GARRELS, 1952). A parte hachuriada representa - campo de estabilidade de deposição dos minerais primários em Serragem e Lagoa do Riacho (Aracoiaba,CE). 
análise sobre a fonte do manganês. Apenas a granulação fina da espessartita e do quartzo no gondito e no granada-quartzito sugere que a área fonte de provisão dos sedimentos se aproximou muito do nivel de base regional.

A falha de Senador Pompeu condicionou a formação de microdobramentos, microfalhamentos e cataclase nas rochas da região (MELO, 1978). O granitóide de serrote pelado é um exemplo deste fenômeno cataclāstico.

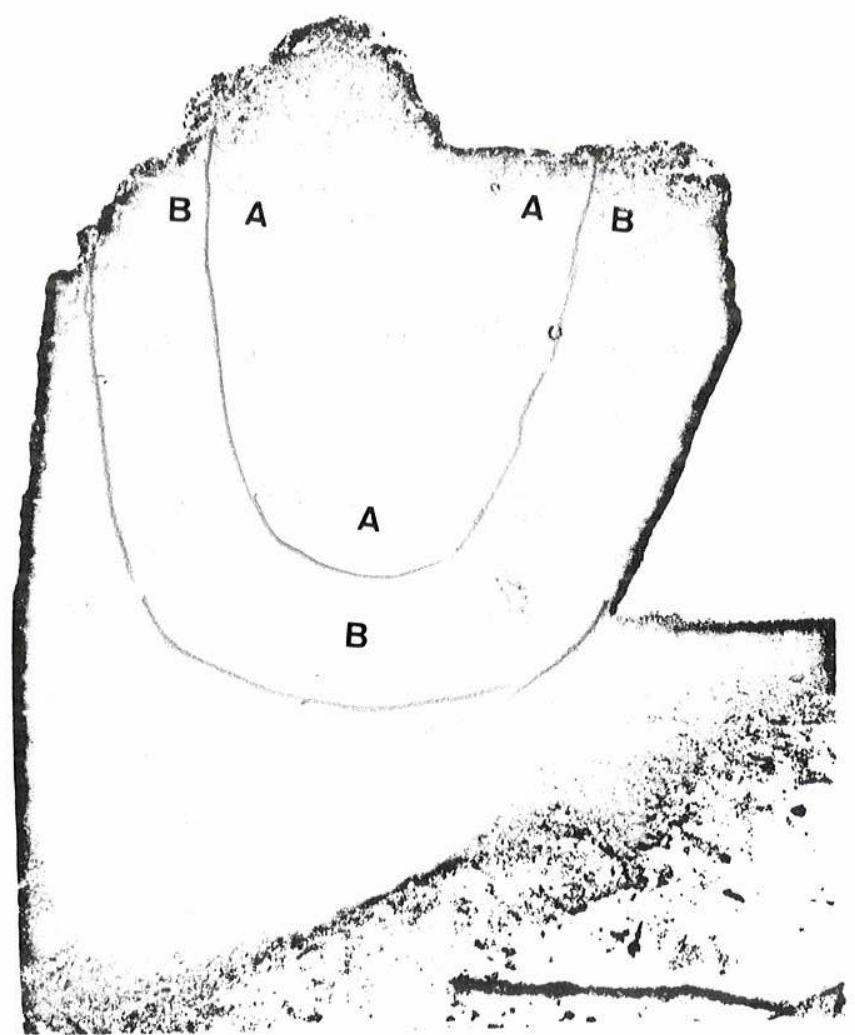

Foto 4 - Gondito (A) encontrado em núcleo de sinclinal encaixado por granada-quartzito (B), localizado no Poço 1 em Serragem (Aracoiaba, CE).

As Fotomicrografias 2 e 3 mostram microdobramentos sinclinais, evidentes pelos arranjos das granadas (pág.64 e 65). 
QUADRO 4

COLUNA LITO-ESTRATIGRAFICA DA PROVINCIA MANGANESIFERA DE ARACOIABA-PACAJÚS (CE)

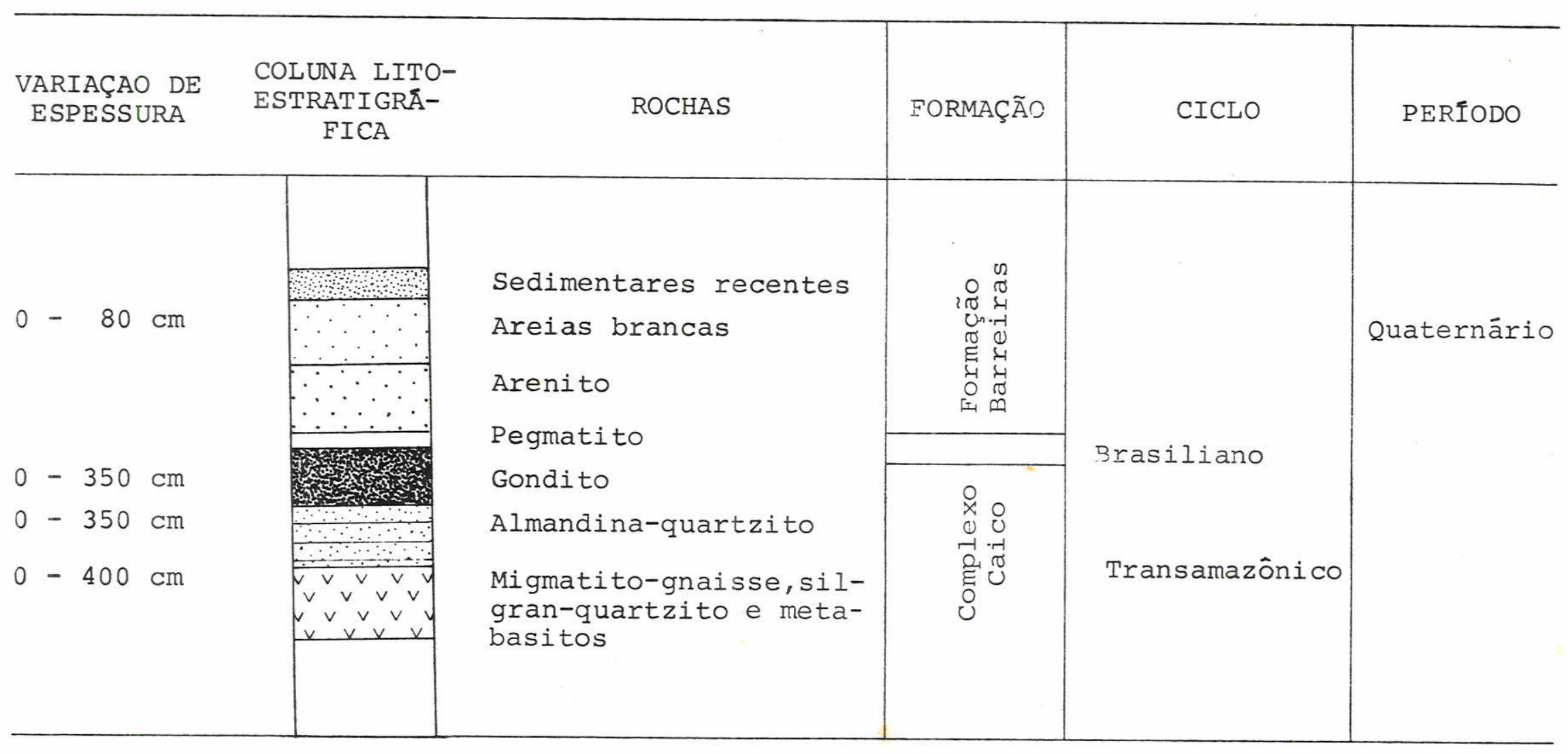




\section{9 - ESTRATIGRAFIA}

De conformidade com as considerações anteriores, a lito-estratigrafia para a área de ocorrência de Serragem e Lagoa do Riacho está resumida no Quadro 4 - pág. 88.

Existe um substrato formado por migmatito-gnaisse, granada-silimanita-quartzito, granada-quartzito, metabasitos e gondito.

Este substrato pertence ao Complexo Caicó, que se implantou no ciclo transamazônico. Durante o ciclo brasiliano foi reativado e cortado discordantemente por intrusões pegmatiticas.

Este conjunto de rochas corresponde aproximadamente à unidade 2 de BRITO NEVES (1975).

Sobre este pacote de rochas deposita-se discordantemente o arenito da Formação Barreiras durante o Terciário.

No Quaternário, durante o Pleistoceno (MABESOONE, Op. Cit.) deposita-se sobre a Formação Barreiras uma formação arenosa branca.

Observe-se que o Grupo Ceará não se acha representado na área restrita ao manganês, a não ser pelo pegmatito que é um produto de um evento magmático contemporâneo à formação de rochas do Grupo Ceará.

$$
8 \text { - O MINERIO }
$$

\section{1 - FEIÇÕES MEGASCÓPICAS}

O minério se apresenta de maneira variada, desde um material compacto até pulverulento. 
Os afloramentos de gondito alterado são classificados como minérios "in situ" e os blocos rolados de gondito, as esferas concêntricas formadas por laterização e as cangas são classificadas como minérios residuais.

A principal feição observada é o acamamento dos leitos alterados, que são paralelos ao acamamento das rochas encaixantes. Esta estrutura é facilmente observável em amostra de mão ou em escala de afloramento. Este acamamento dá ao protominério um aspecto de bandeamento de leitos claros e escuros, que vão se diluindo à medida que se afasta do contato com a rocha encaixante.

Rochas de afloramentos ou blocos rolados estão superimpostos por uma película esférica de $1 \mathrm{~mm}$ de espessura de constituição coloidal. em forma botrioidal e/ou mamilonar.

Comumente resquícios de granada-quartzito de cor beje claro se encontram dentro do gondito, principalmente próximo ao contato.

Observam-se algumas fraturas perpendiculares ou obliquas ao acamamento, preenchidas por colóides de óxidos de manganês.

Em locais restritos (Poço no 34 - Serragem - Anexo I) se observa intensa silificação com a formação de veios - camadas de quartzo leitoso dentro do gondito alterado.

Nota-se nas amostras de óxidos de manganês uma coloração azulada que BRAGA (1977) cita como "eflorescência metálica azulada". Estudes em seções polidas indicam que esta feição se deve à presença de litioforita que confere tonalidade azul aos óxidos de manganês. NAGELL \& SILVA (1961) denominou esta feição de "filme azul iridescente" que recobre o minério de Serra do Navio (AM) e o atribuiu também à presença de litioforita.

Vale ressaltar a presença de estruturas de boxwork, cujos espaços são preenchidos por quartzo e argila. 


\section{2 - MINERALOGIA}

\section{Iitioforita}

A litioforita ocorre em feixes ou isolada, nas fraturas ou entre os grãos de granada; ocorre tambëm de maneira microgranular dentro de uma massa escura constituida de argila e óxidos de ferro e manganês.

Macroscopicamente sua presença è denunciada pela tonalidade azul que ela confere à rocha.

Ao microscópio, sua cor é cinza amarronzada. A birreflectância è muito forte e os efeitos anisotröpicos são extremos, com cores de polarização variando de cinza claro a marrom escuro e cinza azulado. A refletividade estimada é de 12 a $20 \%$ nas posições mais claras e mais escuras, respectivamente.

A litioforita è facilmente identificada em seção polida. Confunde-se apenas com calcofanita e todorokita. Sua distinção se faz inserindo um placa de gipso sob nicóis cruzados;ao rotacionar a platina há uma distinta mudança de azul claro para amarelo claro (De VILLIERS, 1971). Além do mais, a litioforita sempre se apresenta de maneira compacta.

Anälises em amostras com litioforita apresentam um teor de 260 e $240 \mathrm{ppm}$ de $\mathrm{Zn}$; isto sugere a existência de um pouco de todorokita na litioforita (Tabela 16).

ocorre em paragêneses com pirolusita, criptomelano e gama $\mathrm{MnO}_{2}$ (mangano-nsutita).

Em anālise de pó por raio X na massa escura, proveniente de alteração de espessartita, foi detectada um pouco de litioforita (Tabela 13). No entanto, na seção polida correspondente não foram observados o anisotropismo e a birreflectância, a não ser com grande aumento e com pouca intensidade.HOLTROP (1965), afirma que quando a litioforita forma massas finas granuladas é difícil sua identificação sö por seção polida. 
outros filmes de raios $\mathrm{x}$ acusam a existência de 1itioforita em mistura com quartzo e rodonita (Tabelas 9 e 10).

\section{Pirolusita}

A pirolusita ocorre de três maneiras: A - como pseudomorfo de groutita ou manganita em cristais prismáticos (Fotomicrografia 12); B - Em cristais prismāticos pontiagudos preenchendo vazios em deposições coloidais (Fotomicrografia 18) e C em bandeamentos difusos em concreções esféricas (Fotomicrografia 16).

o mineral, em alguns casos, é prontamente reconhecido em seção polida por sua birreflectância distinta e hăbito prismático. A confirmação de sua identidade foi feita em raios $x$ conforme resultados da Tabela 11 .

Há duas gerações de pirolusita: a pirolusita I, que corresponde ao tipo $A$ e a pirolusita II que corresponde aos tipos $B$ e $C$.

\section{Criptome lano}

o criptomelano foi identificado por meio de filme de pó (raios X) e mistura com quartzo (Tabela 12) e com litioforita e gama $\mathrm{MnO}_{2}$ (Mangano-nsutita) (Tabela 13).

COnforme SOREN \& CAMERON (1960), todo criptomelano contēm um pouco de mangano-nsutita. Este mineral, de fato, foi encontrado junto ao criptomelano.

o criptomelano ocorre sob a forma de: a) colóides com gretas de contração juntamente com pirolusita, quartzo e granada; b) como produto de substituição de litioforita ou espessartita, formando massa escura; c) em bandeamentos alternados com pirolusita e espessartita em concreções esfēricas (Fotomicrografia 16).

Hā duas gerações de criptomelano. O criptomelano I que corresponde ao tipo $B$ e o criptomelano II que corresponde aos tipos $A$ e $C$. 


\section{TABELA 9}

DISTANCIAS INTERPLANARES ( $(A \AA)$ OBTIDAS POR DIFRAÇÃO DE RAIOS $X$ (FILME) EM RADIAÇÃO FeK $\alpha$ COMPARADAS COM PADRÃO ASTM

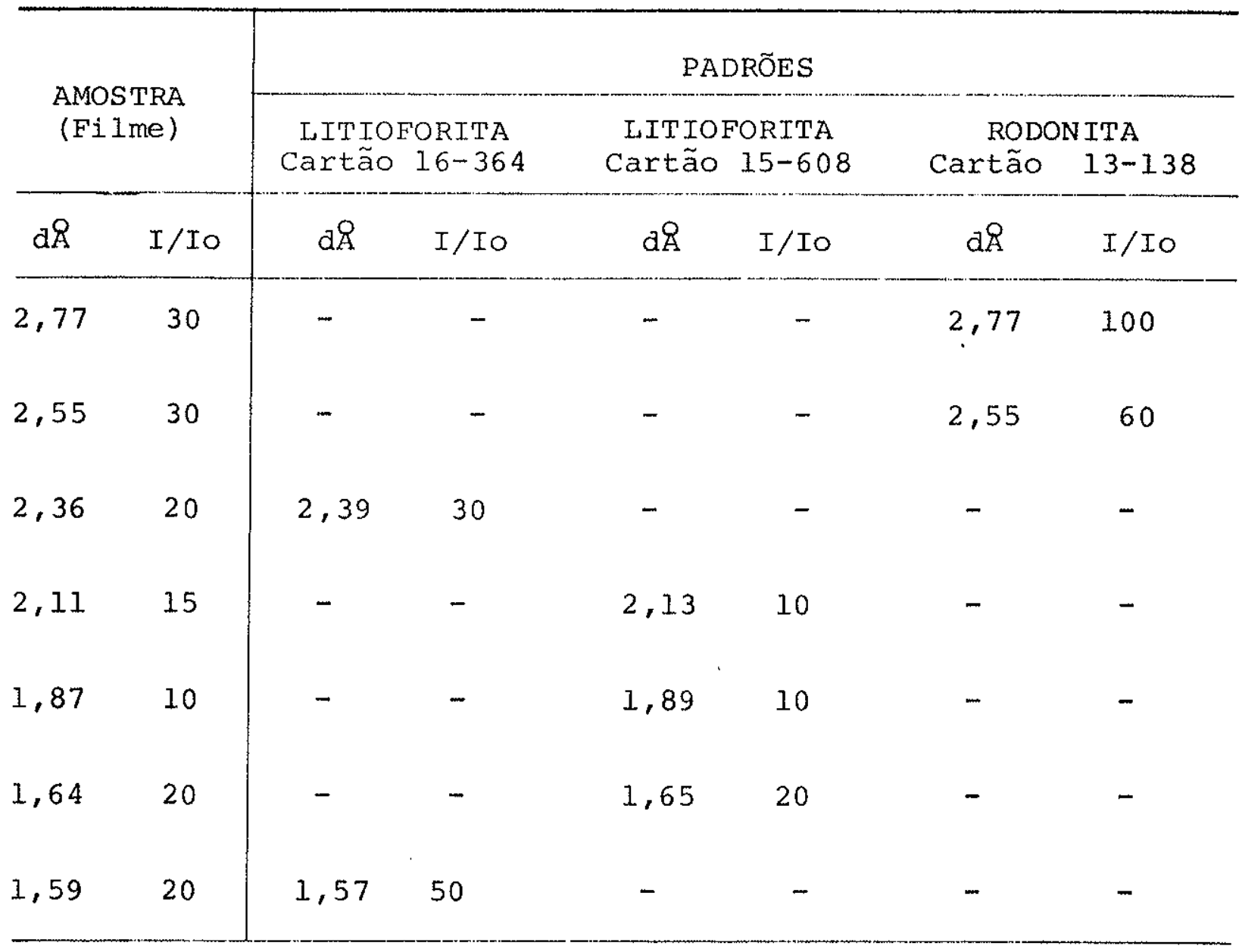


TABELA 10

DISTÂNCIAS INTERPLANARES (đA) OBTIDAS POR DIFRAÇÃO DE RAIOS $X$ (FILME) EM RADIAÇÃO FEK $\alpha$ COMPARADAS COM PADRÃO ASTM

\begin{tabular}{|c|c|c|c|c|c|c|c|}
\hline \multirow{2}{*}{\multicolumn{2}{|c|}{$\begin{array}{c}\text { AMOSTRA } \\
\text { (Filme) }\end{array}$}} & \multicolumn{6}{|c|}{ PADRÕES } \\
\hline & & \multicolumn{2}{|c|}{$\begin{array}{c}\text { LITIOFORITA } \\
\text { Cartão 15-608 }\end{array}$} & \multicolumn{2}{|c|}{$\begin{array}{c}\text { QUARTZO } \\
\text { Cartão } 11-252 \\
\end{array}$} & \multicolumn{2}{|c|}{$\begin{array}{l}\text { ESPESSARTITA } \\
\text { Cartão 2-0992 }\end{array}$} \\
\hline$d \AA$ & I/IO & $d \AA$ & I/IO & $\mathrm{d} \AA$ & I/IO & $a \AA$ & I/Io \\
\hline 4,71 & 5 & 4,76 & 90 & - & - & - & - \\
\hline 4,25 & 10 & - & - & 4,26 & 35 & - & - \\
\hline 3,55 & 100 & - & - & 3,34 & 100 & - & - \\
\hline 3,35 & 20 & - & - & - & - & - & - \\
\hline 2,91 & 30 & 2,93 & 50 & - & - & 2,90 & 50 \\
\hline 2,60 & 5 & - & - & - & - & 2,60 & 100 \\
\hline 2,37 & 5 & 2,39 & 30 & - & - & - & - \\
\hline 2,27 & 5 & - & - & - & - & 2,28 & 12 \\
\hline 2,12 & 10 & - & - & - & - & 2,12 & 9 \\
\hline 2,21 & 10 & - & - & - & - & 2,23 & 6 \\
\hline 2,11 & 20 & - & - & - & - & 2,06 & 70 \\
\hline 1,67 & 20 & 1,68 & 20 & - & - & - & - \\
\hline 1,61 & 30 & 1,65 & 20 & - & - & - & - \\
\hline 1,55 & 5 & 1,58 & 70 & - & - & - & - \\
\hline 1,45 & 5 & 1.45 & 80 & - & - & - & - \\
\hline 1,30 & 5 & 1,39 & 10 & - & - & - & - \\
\hline 1,26 & 10 & 1,25 & 10 & - & - & - & - \\
\hline 1,07 & 5 & 1,07 & 20 & - & - & - & - \\
\hline 1,06 & 10 & - & - & - & - & 1,06 & 1 \\
\hline 1,02 & 10 & - & - & - & - & 1,01 & 2 \\
\hline
\end{tabular}


TABELA 11

DISTÂNCIAS INTERPLANARES ( $(\mathrm{d} \AA)$ OBTIDAS POR DIFRAÇÃO DE RAIOS $x$ (FILME) EM RADIAÇÃO FeK $\alpha$ COMPARADAS COM PADRÕES ASTM

\begin{tabular}{|c|c|c|c|c|c|}
\hline \multirow{2}{*}{\multicolumn{2}{|c|}{$\begin{array}{c}\text { AMOSTRA } \\
\text { (Filme) }\end{array}$}} & \multicolumn{4}{|c|}{ PADRÕES } \\
\hline & & \multicolumn{2}{|c|}{$\begin{array}{c}\text { PIROLUSITA } \\
\text { Cartão } \quad 12-716\end{array}$} & \multicolumn{2}{|c|}{$\begin{array}{c}\text { GRANADA } \\
\text { Cartão } \quad 2-0992\end{array}$} \\
\hline$a \AA$ & I/IO & $a \AA$ & I/IO & $\mathrm{d} \AA$ & I/IO \\
\hline 3,17 & 40 & 3,14 & 100 & - & $-\cdots$ \\
\hline 1,57 & 40 & 1,56 & 25 & - & $-\cdots$ \\
\hline 2,57 & 100 & - & - & 2,57 & 100 \\
\hline 1,33 & 5 & 1,31 & 20 & - & - \\
\hline 2,25 & 5 & 2,21 & 5 & - & - \\
\hline 1,86 & 5 & 1,81 & 5 & - & - \\
\hline 1,66 & 40 & 1,68 & 40 & - & - \\
\hline 1,59 & 40 & 1,56 & 25 & - & - \\
\hline 1,53 & 60 & - & - & 1,55 & 80 \\
\hline 1,28 & 5 & - & - & 1,27 & 60 \\
\hline 1,25 & 5 & 1,25 & 5 & - & - \\
\hline 1,22 & 5 & 1,20 & 5 & - & - \\
\hline 1,05 & 10 & 1,05 & 15 & - & - \\
\hline
\end{tabular}


TABELA 12

DISTÂNCIAS INTERPLANARES (dA) OBTIDAS POR DIFRAÇÃO DE RAIOS $X$ (FILME) EM RADIAÇÃO FeK $\alpha$ COMPARADAS COM PADRÕES ASTM

\begin{tabular}{|c|c|c|c|c|c|}
\hline \multirow{2}{*}{\multicolumn{2}{|c|}{$\begin{array}{c}\text { AMOSTRA } \\
\text { (Filme) }\end{array}$}} & \multicolumn{4}{|c|}{ PADRÕES } \\
\hline & & \multicolumn{2}{|c|}{ 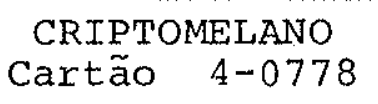 } & \multicolumn{2}{|c|}{$\begin{array}{c}\text { QUARTZO } \\
\text { Cartào 5-0490 }\end{array}$} \\
\hline $\mathrm{d} \AA$ & I/IO & $d \AA$ & I/IO & $d \AA$ & I/IO \\
\hline 4,26 & 10 & - & - & 4,26 & 35 \\
\hline 3,34 & 100 & - & - & 3,34 & 1.00 \\
\hline 3,12 & 10 & 3,11 & 80 & - & - \\
\hline 2,40 & 10 & 2,48 & 30 & - & - \\
\hline 2,15 & 5 & 2,14 & 30 & - & - \\
\hline 1,81 & 5 & 1,82 & 50 & - & - \\
\hline 1,53 & 5 & 1,53 & 20 & - & - \\
\hline 1,37 & 2 & 1,38 & 2 & - & - \\
\hline
\end{tabular}


TABELA 13

DISTANCIAS INTERPLANARES (d尺) OBTIDAS POR DIFRAÇÃO DE RAIOS $X$ (FILME) EM RADIAÇÃO FeK $\alpha$ COMPARADAS COM PADRÕES $(a, b, c$ e d)

\begin{tabular}{|c|c|c|c|c|c|c|c|}
\hline & & \multicolumn{6}{|c|}{ PADRÕES } \\
\hline \multicolumn{2}{|c|}{$\begin{array}{c}\text { AMOSTRA } \\
\text { (Filme) }\end{array}$} & \multicolumn{2}{|c|}{ LITIOFORITA } & \multicolumn{2}{|c|}{ CRIPTOMELANO } & \multicolumn{2}{|c|}{$\mathrm{YMnO}_{2}(\mathrm{NSUTITA} \mathrm{Mn})$} \\
\hline $\mathrm{d} \AA$ & I/IO & $d \AA$ & I/IO & $d \AA$ & I/IO & $d \AA$ & I/IO \\
\hline 9,71 & 10 & 9,40 & 9 & - & - & - & - \\
\hline 6,98 & 10 & - & - & 6,98 & 48 & - & - \\
\hline 4,72 & 20 & 4,70 & 20 & - & - & - & - \\
\hline 4,19 & 5 & - & - & - & - & 4,10 & 100 \\
\hline 3,72 & 5 & & & & & 3,75 & $\simeq 5$ \\
\hline 3,39 & 100 & & Imp & & não & ntificada & \\
\hline 3,12 & 5 & 3,13 & 3 & 3,13 & 10 & - & - \\
\hline 2,89 & 5 & & Imp & & não & ntificada & \\
\hline 2,37 & 20 & - & - & 2,39 & 20 & - & - \\
\hline 1,67 & 30 & - & - & 1,64 & 30 & - & - \\
\hline 1,22 & 5 & - & - & 1,23 & 5 & 1,22 & 10 \\
\hline 1,15 & 5 & - & - & 1.15 & 10 & 1,13 & 10 \\
\hline 1,11 & 2 & - & - & - & - & 1,11 & $<2$ \\
\hline
\end{tabular}
a - Fleischer and Richmond (1943)
b - Univ. of Wis. Spec. no A34-1 (NSUTA)
c - ASTM - cartão - 14-614 (Mangano-Nsutita)
d - Univ. of Wis. Spec. no A97-(NSUTA) 


\section{Mangano-nsutita (Gama $\mathrm{MnO}_{2}$ )}

Um mineral de estrutura gama $\mathrm{MnO}_{2}$ foi detectado por meio de interpretação de filme de raios $x$, em mistura com litioforita microgranular e criptomelano (Tabela 13). Em vista da paragênese com criptomelano e do padrão ASTM (1965) supõe-se que se trata de mangano-nsutita. Não existe certeza absoluta neste caso, em vista da pouca claridade do filme e de grande variedade de padrões gama $\mathrm{MnO}_{2}$ (SOREN \& CAMERON, Op.Cit.). Mas, sem đûvida, se trata de um óxido de manganês do grupo $\gamma \mathrm{MnO}_{2}$.

As diferenças do padrão ASTM (1965) devem ser creditadas à mistura com criptomelano ou talvez, à pequena quantidade de pirolusita (SOREN \& CAMERON, Op.Cit.). LEVIN \& TAUBER (Apud SOREN \& CAMERON, Op.Ci.t.) afirmam que há uma variedade quase infinita de gama $\mathrm{MnO}_{2}$. O mineral, ora identificado em Serragem (Aracoiaba) tem espaços interplanares semelhantes aos padrões do cartão no $14-614$ (ASTM).

o mineral observado em seção polida ocorre de maneira semelhante à mangano-nsutita descrito por SOREN \& CAMERON (1960), nos depósitos de Gold Cost (Ghana), onde as rochas deformadas são substituídas por Nsuta $-\mathrm{MnO}_{2}$ e por goethita. $\mathrm{Em}$ Ghana, no entanto, este mineral ocorre abundantemente.

\section{3 - FEIÇÕES TEXTURAIS}

\section{Textura religuiax}

A textura reliquiar está evidente pelos fragmentos de granada e quartzo, que restaram apös sua substituição (Fotomicrografia 10).

Esta substituição ē gradacional; vai desde o simples indicio de alteração por corrosão nos bordos (Fotomicrografia 10) até a substituição total da granada por silicatos de alumí- 


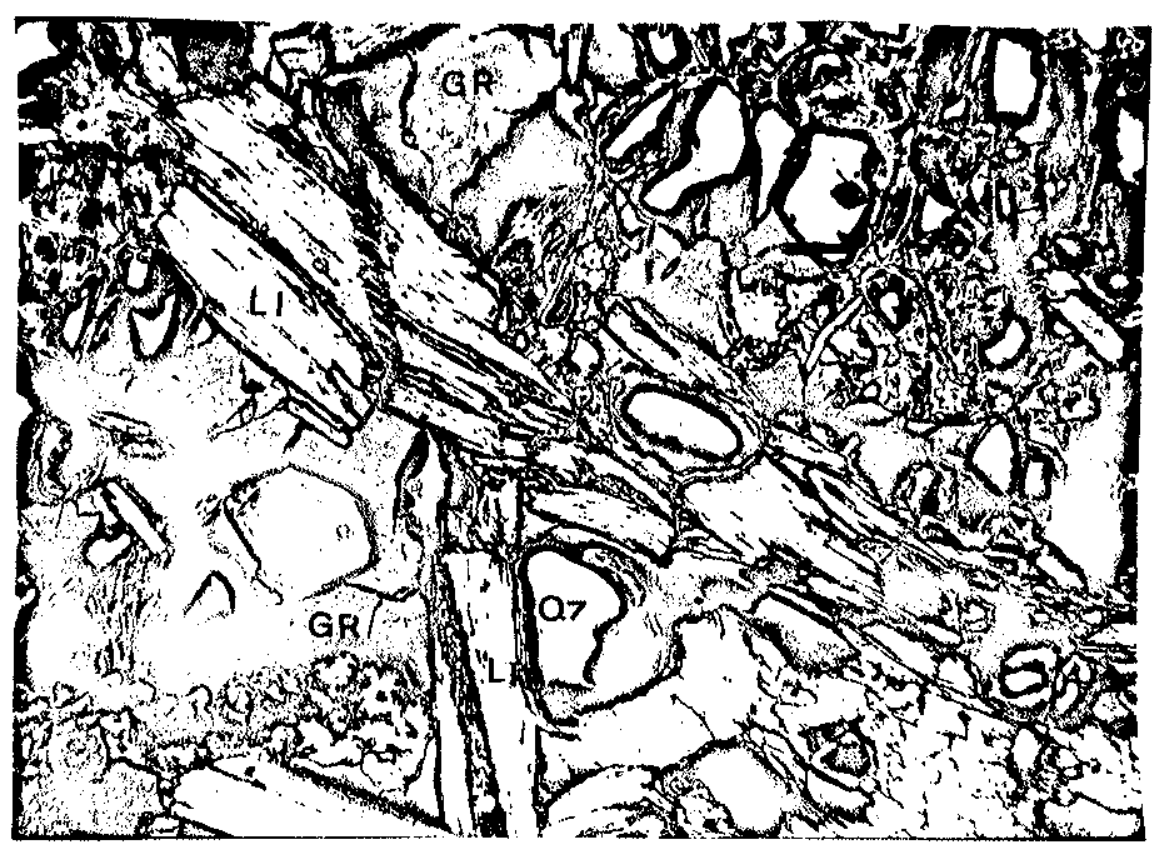

Fotomicrografia 10 - Superfície polida de gondito alterado mostrando granada $(g r)$, quartzo $(q z)$ e placas de litioforita (1i) e criptomelano (crip). Observam-se algumas granadas fraturadas e substituidas nos bordos por massa escura composta de óxido de manganês e hidrossilicatos de ferro. As outras granadas foram substituidas totalmente, conservando a forma original. Nicóis paralelos; Aumento $95 \mathrm{x}$.

nio (argilas) e por óxidos de manganês, permanecendo apenas a forma original da granada (Fotomicrografia 10).

A feição textural de estágio final deste processo poderia tambēm ser denominada de "textura de substituição pseudomórfica" (BASTIN, 1950), evidenciada pelos contornos dos cristais de granada que permanecem após sua substituição.

O tamanho da granada varia desde $0,60 \mathrm{~mm}$ até $0,012 \mathrm{~mm}$ de comprimento por 0,12 a $0,06 \mathrm{~mm}$ de largura. Predomina a granulação variável entre 0,12 a $0,24 \mathrm{~mm}$. 


\section{Textura reliquiar zonada}

Um fragmento central se altera em bandas claras e escuras. Este fragmento central pode ser uma granada, um óxido de ferro ou de manganês. A granada como nücleo central apresenta as formas de pentágono, de retângulo, de losango ou mesmo de triângulo esférico (Fotomicrografia 11).

As bandas claras e escuras são formadas de minerais finamente cristalizadas que se constituem de óxidos de ferro (bandas escuras) e criptomelano (bandas claras) (Fotomicrografia 11).

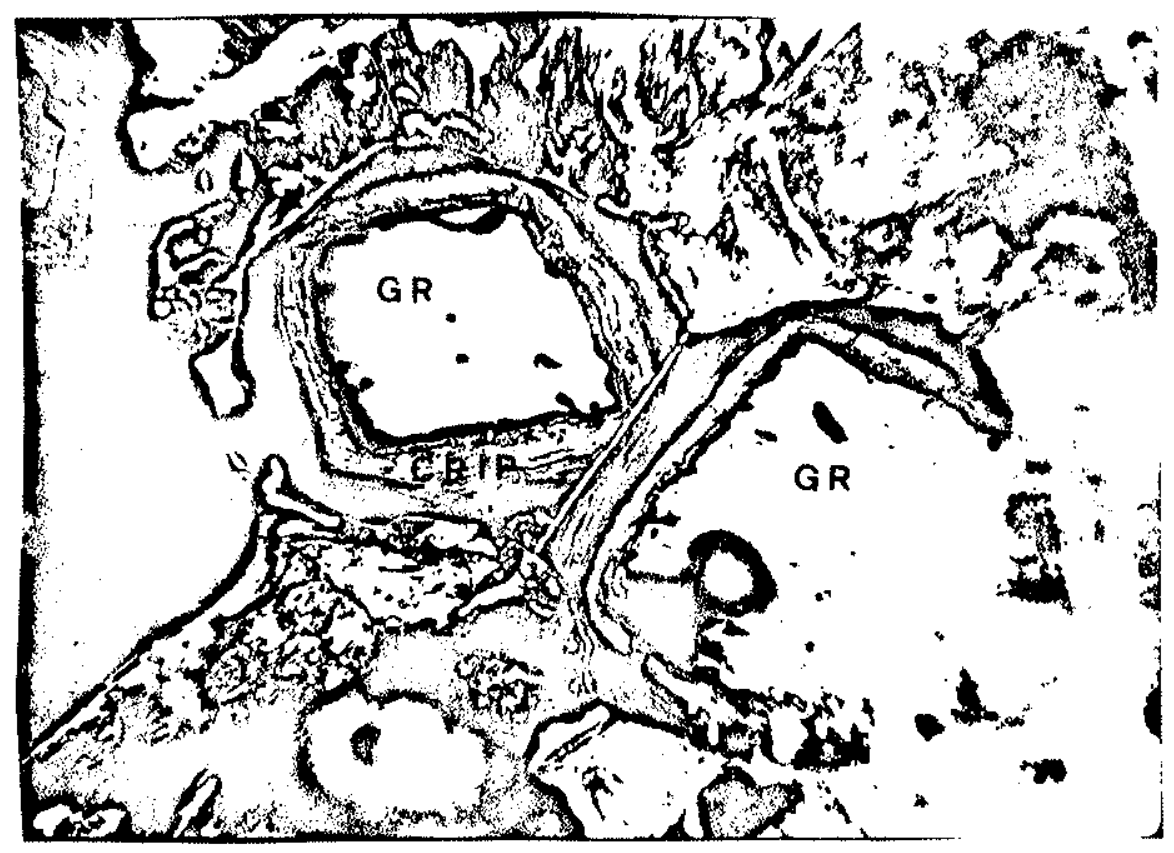

Fotomicrografia 11 - Superfície polida de gondito alterado mostrando textura reliquiar zonada; a granada $(g x)$, que constitui o nücleo, é substituída por minerais claros (Crip I) e minerais escuros (hidröxidos de ferro). 


\section{Textura em retalhos}

Existem partículas de quartzo $(0,06 \mathrm{~mm})$ em forma triangular englobadas por cristais de pirolusita de 0,12 a 0,36 mm de comprimento, nos quais se observam nitidamente as clivagens (110) (ORCELL, 1931). De acordo Com VALARELLI (1967) trata-se de pirolusita pseudomorfa segundo groutita e/ou manganita (Fotomicrografia 12).

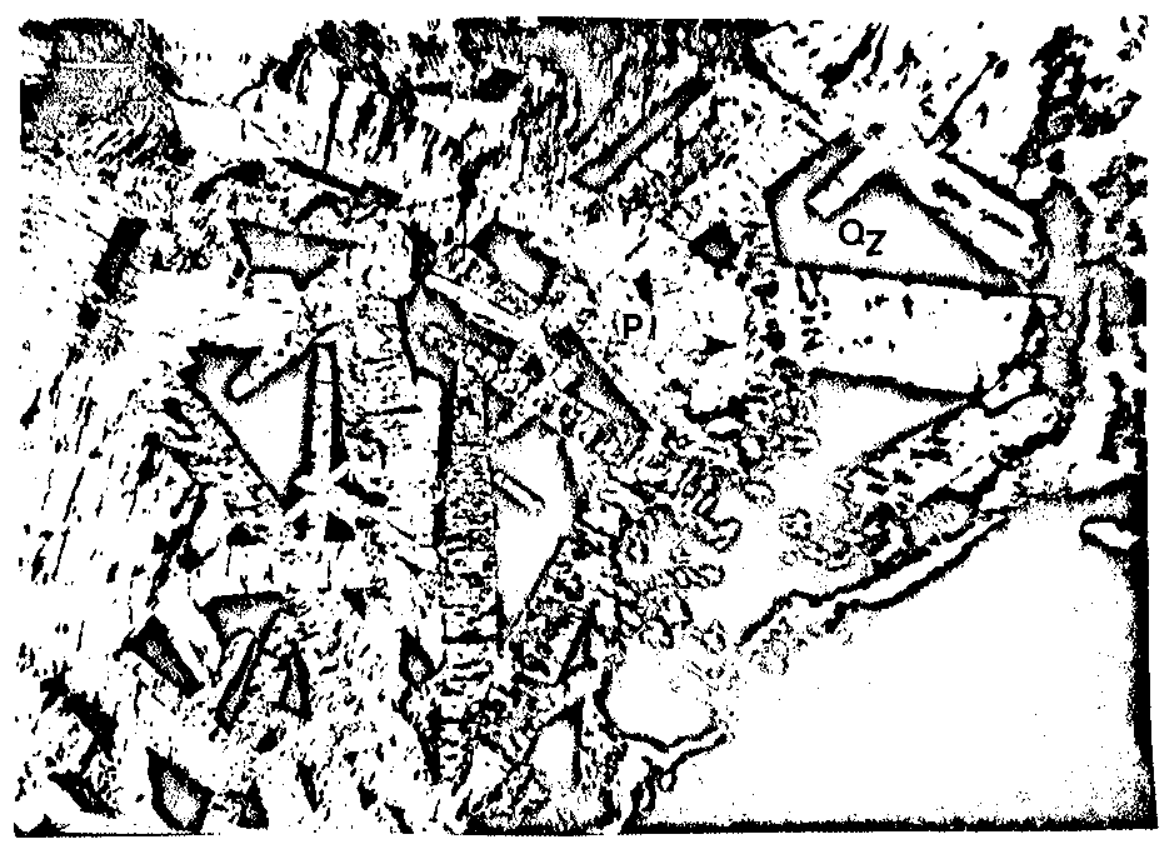

Fotomicrografia 12 - Superfície polida de gondito alterado mostrando cristais prismáticos de pirolusita pseudomorga segundo groutita ou manganita. Nicōis cruzados: Aumento $330 \mathrm{x}$. 


\section{Textura de borda}

A litioforita é englobada por uma camada estreita de óxidos de manganês (pirolusita), que penetram também em seus planos de clivagem (Fotomicrografias 10 e 13 ).

A granada apresenta em seus bordos óxidos de ferro e de manganês. Estes óxidos, às vezes, deixam um contorno em formato de granada (Fotomicrografia 10). A substituição provavelmente se dá segundo planos cristalográficos que são perpendiculares às faces do cristal.

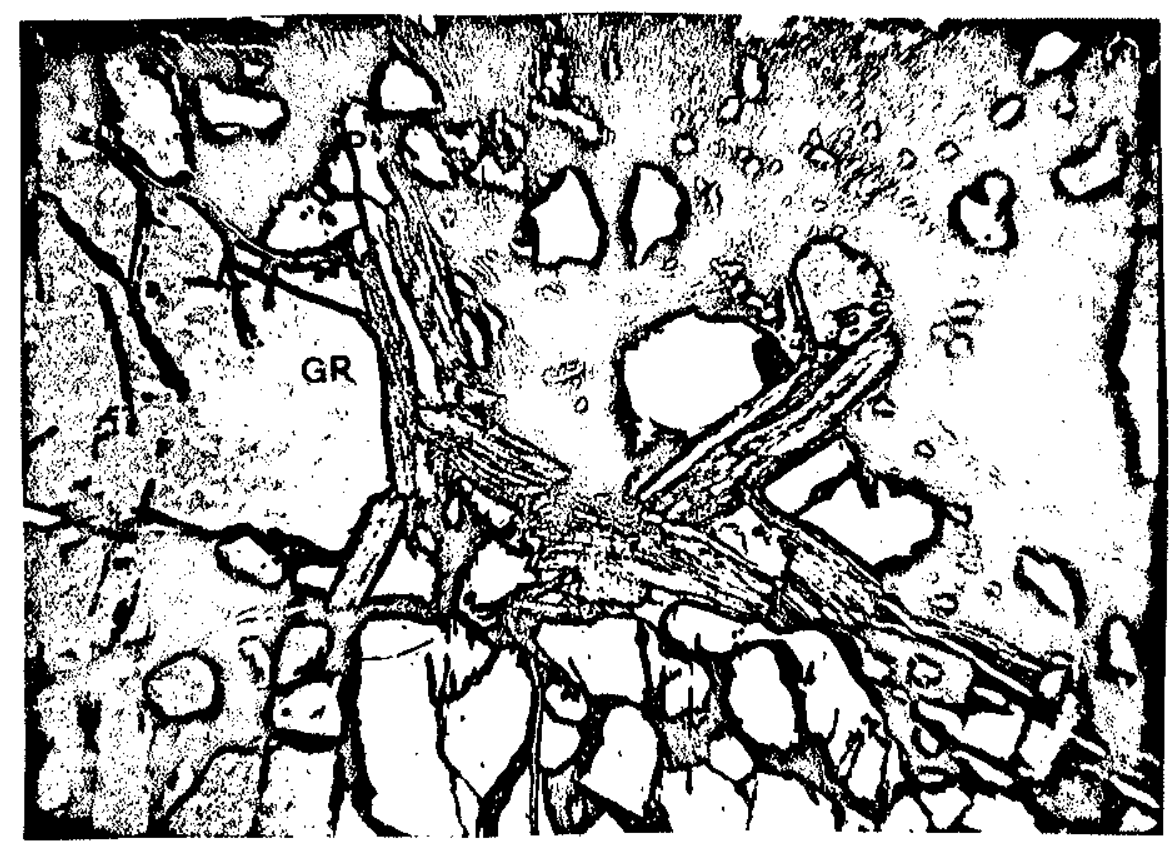

Fotomicrografia 13 - Superfície polida de gondito alterado mostrando pirolusita (pi) em textura de borda entre clivagens da litioforita (1i), que se situa entre os grãos de granada ( $g r)$. Nicóis cruzados; Aumento $28 \mathrm{x}$. 


\section{Textura brechada e filiforme}

A espessartita se acha totalmente fraturada. Alguns cristais lembram a textura de bomba explodida (Fotomicrografia 14).

Os minerais ripiformes (Iitioforita) apresentam,algumas vezes, textura de curvamento ("Rumpled Texture") de cristais (SCHWARTZ, 1951) (Fotomicrografia 15); outras vezes, apresentam feições filiformes decorrentes do desmembramento de feixes de minerais de litioforita, segundo a clivagem longitudinal (Fotomicrografias 14 e 15).

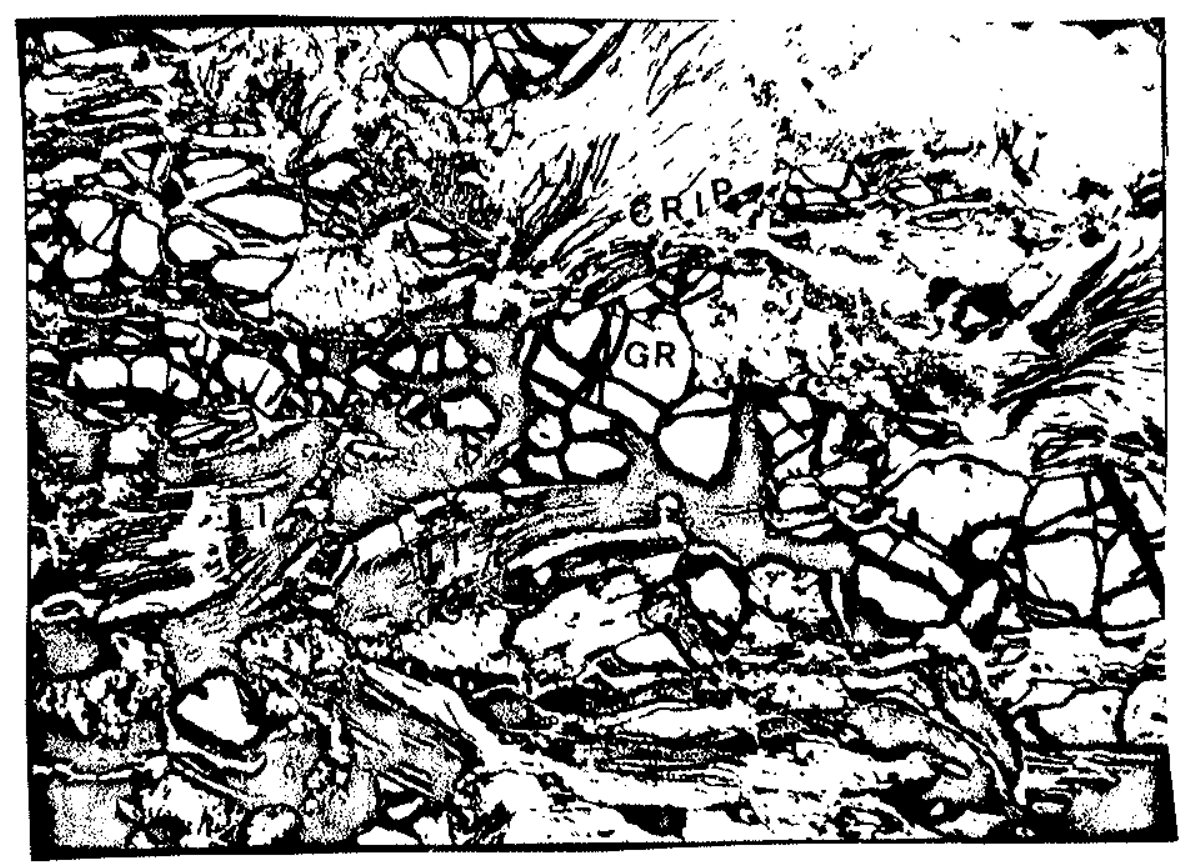

Fotomicrografia 14 - Superficie polida de gondito alterado mostrando textura filiforme de litioforita (li) sendo substituida por criptomelano (crip). Os cristais de granada ( $g r)$ tem textura brechada semelhante à textura de "bomba explodida". Nicóis cruzados; Aumento 44 X. 
Os cristais filiformes de litioforita se encurvam dando, às vezes, uma feição vermiforme (Fotomicrografia 15); outras vezes, estes fios de litioforita se organizam de tal maneira que se assemelham a impressões digitais, dentro de criptomelano que a substituem (Fotomicrografia 14).

As dimensões da litioforita variam de $0,60 / 0,08 \mathrm{~mm} e$ $0,09 / 0,03 \mathrm{~mm}$ de comprimento e largura respectivamente.

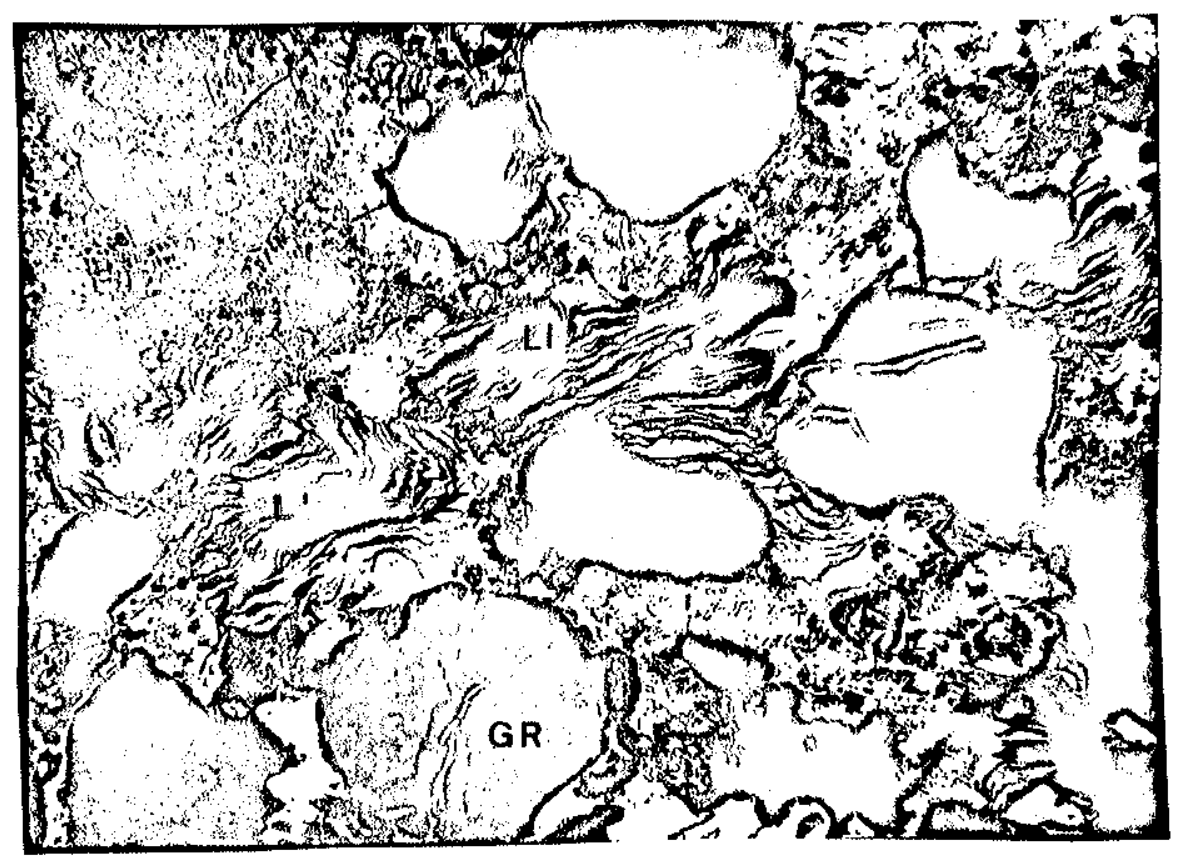

Fotomicrografia 15 - Superfície polida mostrando gondito alterado com textura de curvamento dos filamentos de litioforita (li) (Rumpled Texture) dentro de criptomelano (Crip) e de pirolusita ( $p i)$. A granada $(g r)$ se acha fraturada. Nicóis cruzados; Aumento $28 \mathrm{x}$. 


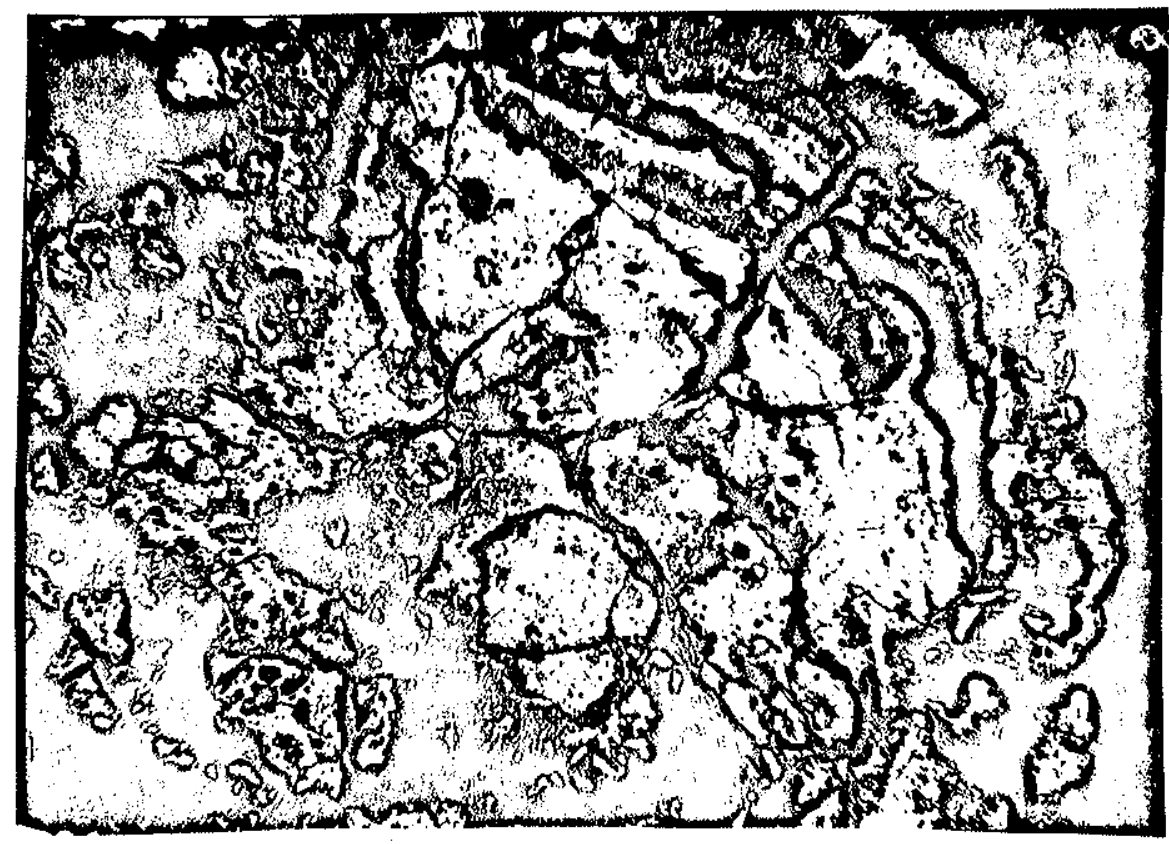

Fotomicrografia 16 - Superfície polida de esfera concêntrica de óxidos de manganês, mostrando textura nodular concêntrica. As partes claras são constituídas de óxidos de manganês (criptomelano e pirolusita). Nicóis cruzados; Aumento $17,5 \mathrm{x}$.

\section{Textura nodular concêntrica}

A textura nodular concêntrica é representada por nódulos lateriticos constituídos de círculos concêntricos de pirolusita e criptomelano, de cores cinza-claro que se alternam em círculos concêntricos de grãos de granada finamente granulada $(0,02$ a $0,12 \mathrm{~mm})$, de cores cinza-amarronzada (Fotomicrografia 16).

O tamanho e quantidade dos grãos de granada aumentam de dentro para fora do nódulo.

Observam-se, nos circulos concêntricos, fendas radiais de dessecação, que indicam ter havido uma deposição coloidal (Fotomicrografia 16). 


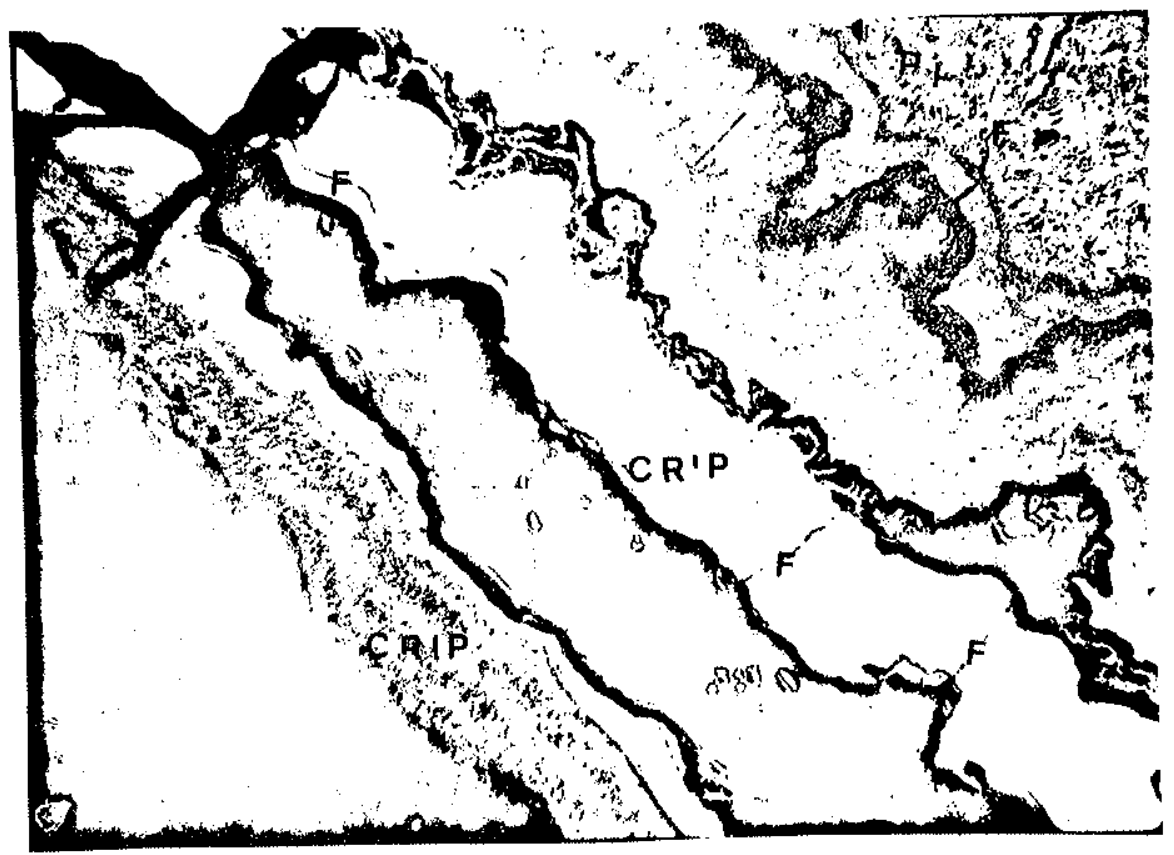

Fotomicrografia 17 - Superfície polida de gondito alterado mostrando textura de bandeamento coloforme de criptomelano, apresentando formas esferoidais de sillica (si), fendas de dessecação (F) e textura de grânulos micrométricos de öxídos de manganês (veio do canto SW). Nicöis cruzados; Aumento $75 \mathrm{X}$.

\section{Textura coloforme}

A textura de bandeamento coloforme èstá evidenciada por três aspectos (Fotomicrografia 17):

1 - Formas esferoidais de silica e de óxidos de manganês (criptomelano).

2 - Fendas de dessecação, na direção do raio de curvatura de formas esferoidais de óxidos de manganês.

3 - Fendas de dessecação paralelas às paredes de veios preenchidos. 
4 - Texturas de grânulos micromētricos de óxidos de manganês, constituídos de criptomelano.

Atente-se para o fato de que o tipo de fraturamento de fendas de desseç̧ão (SHRINKAGE CRACKS) é restrito a formas esferoidais presumidamente coloidais (BASTIN, 1950). Tal relacionamento indica que este fraturamento não é produto de deformações externas, mas sim de perda d'água em seu interior.

\section{Textura coloforme estalactítica}

Existe tambérn uma variedade de textura coloforme - a textura estalactítica, que é constituída por bandeamentos circulares em torno de um núcleo, que pode ser um poro ou um mineral de granada (Fotomicrografia 18). São bandeamentos curvos, alternadamente claros (criptomelano) e escuros (hidróxidos de ferro). Trata-se de um correspondente coloidal de textura reliquiar zonal. Sendo assim, poder-se-ia denominar de textura zonal coloidal. 


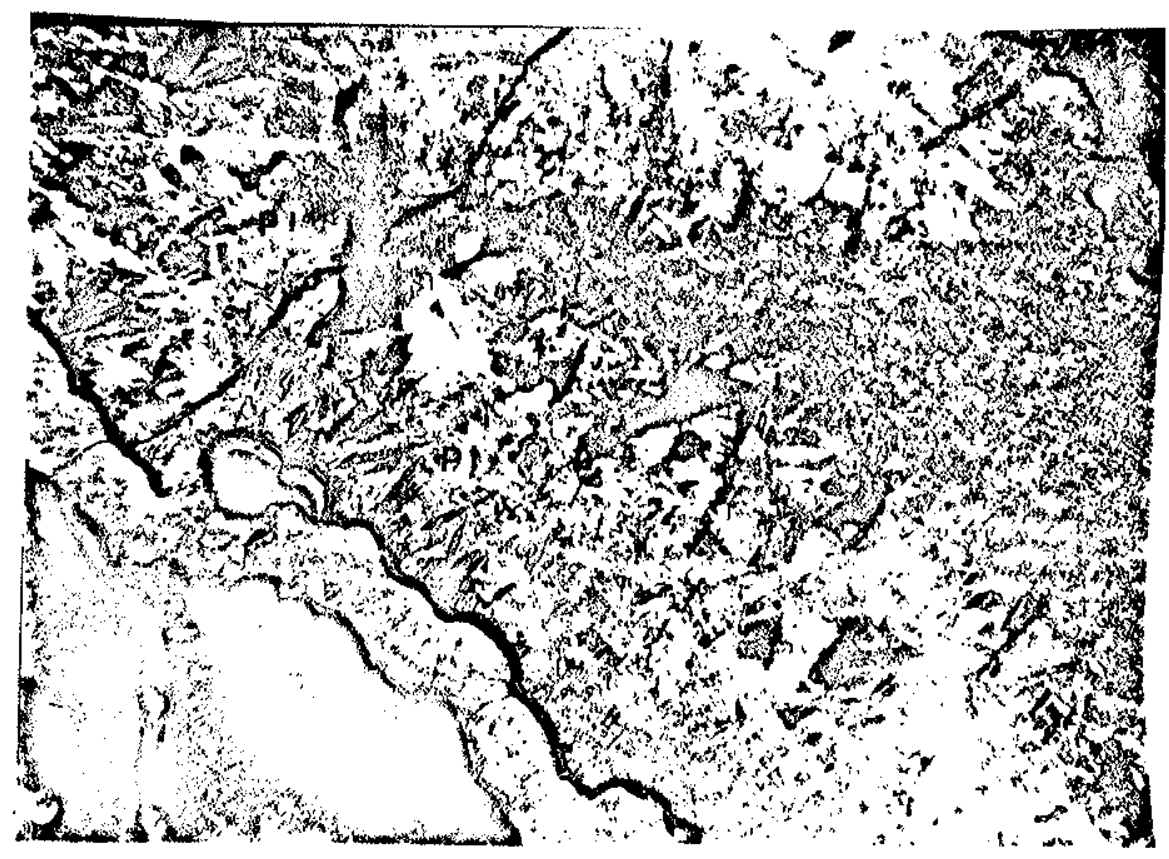

Fotomicrografia 18 - Superficie polida de gondito alterado mostrando textura em pente de pirolusita (pi), preenchendo vazios centrais de deposição coloidal de criptomelano. No canto SW observa-se textura coloforme estalactitica, constituida por bandeamentos circulares (tce).

Normalmente, quando o minërio se encontra em fase avançada de intemperismo, observam-se pseudo-dobras em "chevron" de camadas de óxidos de manganês (Figura 26) dentro de uma massa escura informe. A formação desta textura se deve ao preenchimento de espaços intergranulares de granada por colöides de manganês (Figura 25) e à posterior substituição da granada ( $F$ gura 26).

Algumas vezes estes veios de óxidos de manganês são orientados perpendicularmente ao acamamento geral do minério. 


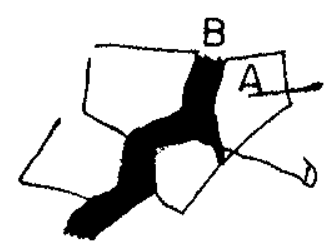

Figura 25 - Veio de óxido de manganês (B) preenchendo vazios entre granadas $(A)$
Figura 26 - I - pseudo-dobras em chevron de óxidos de manganês.

são soluções coloidais descendentes constituídas de criptomelano e pirolusita.

Estes veios observados em seções polidas podem ser observados tambēm em amostra de mão.

\section{Textura em pente}

Esta textura é formada exclusivamente por cristais individuais de pirolusita de 0,12 a $0,36 \mathrm{~mm}$ de comprimento, cujos maiores comprimentos são perpendiculares a um bandeamento difuso formado por criptomelano. Geralmente ocupam os espaços vagos em texturas coloidais e por isso são posteriores aos minerais de deposição coloidal (Fotomicrografia 18).

\section{Textura de Boxwork}

Os óxidos de manganês formam paredes que englobam óxidos de ferro (limonita), configurando uma textura típica de "boxwork".

A estrutura de"boxwork (em amostra de mão) è melhor observada do que a textura em seção polida. 
8.4 - SIGNIFICAÇÃO GENÉTICA DAS I'EXTURAS

8.4.1 - PROCESSOS DE FORMAÇAO DO MINERIO

As texturas pös-deposicionais, anteriormente descritas, indicam quatro processos que influenciaram diretamente na formação do minério:
a - Processo de Deformação
b - Processo de Substituição
c - Processo de Preenchimento de Cavidades
d - Processo de Laterização

o processo de deformação está evidenciado pelo alto grau de fraturamento a que foi submetido o protominério(Textura Brechada). Este processo foi o fator inicial e dominante em todo o desenvolvimento de alteração da rocha primāria. A existência de veios concordantes de quartzo e granada, inalterados e sem nenhum fraturamento, reforça a assertiva anterior.

Fenômenos como microdobramentos, amarrotamentos e curvamentos da litioforita ao longo de seu comprimento("Rumpled Texture") são reflexos de um esforço externo a que foram submetidas as rochas, mesmo durante o processo de oxidação.

o processo de substituição é indicado pelas texturas reliquiares e de borda atuantes na formação do minério, a partir da granada. Da mesma forma, estas texturas indicam que a grande maioria dos minerais secundários provieram diretamente da alteração da granada.

o processo de formação do minério por meio de preenchimento de cavidades está evidenciado pelas texturas coloforme e por texturas em pente. Estes colóides se depositam em fraturas e em planos de acamamentos segundo bandeamentos simétricos e assimétricos. 
o processo de laterização è o menos intenso na formação do minērio. Consiste praticamente na dissolução do manganês como $\mathrm{Mn}^{2}$ e na precipitação como $\mathrm{Mn}^{4}$ (HOLTROP, 1965). Geralmente esta laterização se verifica sobre o protominērio em região muito plana, ocorrendo a remoção simultânea do $\mathrm{SiO}_{2}$. A textura típica deste processo é a textura nodular concêntrica, que se encontra nas esferas concêntricas de óxidos de manganês que formam níveis de deposição de cangas sobre o protominério.

\subsection{2 - TIPOS DE MINERIO EM RELAÇAO AOS PROCESSOS DE FORMAÇAO}

Baseados nos processos acima referidos, evidenciam-se três tipos de minerais secundārios: o primeiro consiste de óxidos de ferro e manganês formados principalmente por processos de substituição parcial da granada. Este minério forma aproximadamente $60 \%$ do total. O minério, por este processo, se forma em grande parte da granada e do quartzo; é constituido de litioforita, pirolusita I, criptomelano I e mangano-nsutita; outra parte se forma de óxidos finamente granulados e recristalizados em pirolusita I, que se forma a partir da groutita ou manganita.

o segundo tipo de mineral secundārio é característico de preenchimento de cavidades. Este consiste de óxidos de manganês e óxidos de ferro que se depositaram em fraturas e fendas da rocha. E constituído de pirolusita II e criptomelano II.

o terceiro tipo de mineral secundārio è o laterítico. Este é insignificante na ārea; è constituído de nódulos concêntricos de pirolusita e criptomelano.

A ganga è constituida essencialmente de quartzo, granada e öxidos de ferro.

\section{4 .3 - FASES E CARACTERTSTICAS DO INTEMPERISMO}

Cada textura ou conjunto de texturas representa uma 
fase de alteração do protominério. Baseado neste princípio, verifica-se um escalonamento de texturas no tempo, de acordo com - grau de alteração do protominērio. Com este critērio, divide-se o intemperismo em várias fases:

\section{1 a fase - Fraturamento}

o protominério, antes do intemperismo, era compacto, caractexizado por textura em mosaico. Devido a pressões externas, se formou um espaçamento maior entre os grãos. Com o aumento de intensidade de deformação houve um fraturamento em toda a extensão da rocha (Textura Brechada).

2 a fase - Formação de Litioforita (Início de Intemperismo

Formou-se primeiramente a litioforita. Ela se encontra preenchendo os espaços intergranulares e as fraturas (Textura de substituição e Textura filiforme).

\section{3a fase - Formação de Pirolusita, Criptomelano e Man- gano-nsutita}

Posteriormente, hä a formação de pirolusita I e de criptomelano I, favorecida pelo intenso fraturamento. São típicas desta fase as texturas de borda ou reliquiares.

\section{$\underline{4 \text { a fase - Intemperismo total da granada }}$}

Com o avanço do intemperismo hā transformação total de granadas em hidróxidos de ferro e öxidos de manganês. E testemunha desta fase a textura de substituição pseudomōrfica, onde persistem apenas os contornos das granadas.

\section{5 - fase - Preenchimento de cavidades}

Nesta fase, verifica-se o preenchimento de espaços vazios por soluções coloidais de Mn (Criptomelano II e Pirolusita II). São testemunhas desta fase as texturas coloformes e texturas em pente.

Esta quinta fase pode em alguns casos preceder à quarta. Isto acontece, quando em niveis superiores se dissolve o 
$\mathrm{Mn}^{+2}$ em soluções que descem por gravidade e preenchem fraturas entre granadas que serão posteriormente intemperizadas. Este fenômeno coincide com a formação das pseudo-dobras em seções polidas descritas em item anterior.

\section{6 a fase - Formação de Esferas Manganesiferas}

A lixiviação de $\mathrm{SiO}_{2}$ e a concentração residual de óxidos de manganês em nōdulos concêntricos constituem a parte final do processo de intemperismo. São testemunhas desta fase as texturas de "boxwork" e a textura nodular concêntrica.

Observe-se que todas estas fases podem se superpor durante o desenvolvimento do intemperismo, tendo em vista que o intemperismo não se deu de maneira contínua e sim em função de elevações e abaixamento do nível de base local, que influenciou diretamente no posicionamento do lençol freático.

Em resumo, podem ser alinhados como fenômenos ao longo do intemperismo os seguintes fatores: 1 - Alteração das rochas manganesíferas. 2 - Liberação do manganês. 3 - Concentração residual de óxido de manganês. 4 - Migração do manganês restante. 5 - Precipitação do manganês restante substituindo o quartzo ou preenchendo cavidades em forma coloidal.

o fenômeno de intemperismo se processa até uma profundidade de $23 \mathrm{~m}$ geralmente, alcançando o máximo de $37 \mathrm{~m}$ em gnaisse decomposto (Perfil A'B', pág.41).

Os minerais que se alteram e contribuem para a formaÇão do minério são espessartita, rodonita e mangano-cumingtonita. A rodonita e mangano-cumingtonita podem ter formado silicatos hidratados intermediärios que formaram óxidos de manganês e hidróxidos de ferro. Esta colaboração, entretanto, foi muito pequena em relação à alteração da espessartita. Esta granada comumente se transforma em hidrossilicatos, liberando manganês que se precipitam como criptomelano e pirolusita, em forma coloidal (VALARELLI et al., 1976). Nestes casos comumente a pirolusita se deposita em segundo lugar. Isto é observado em seção polida, em função da densidade de fendas de dessecação nos bandeamentos colo- 
formes e a partir da textura em pente da pirolusita.

Da alteração direta da espessartita se formou a litioforita que, por sua vez, é substituida por pirolusita, criptomelano, mangano-nsutita e groutita ou manganita. Da groutita se formou a pirolusita pseudomorfa.

Baseado nestes fatos, sugere-se o seguinte esquema para a formação dos compostos de manganês no sistema ora estudado:
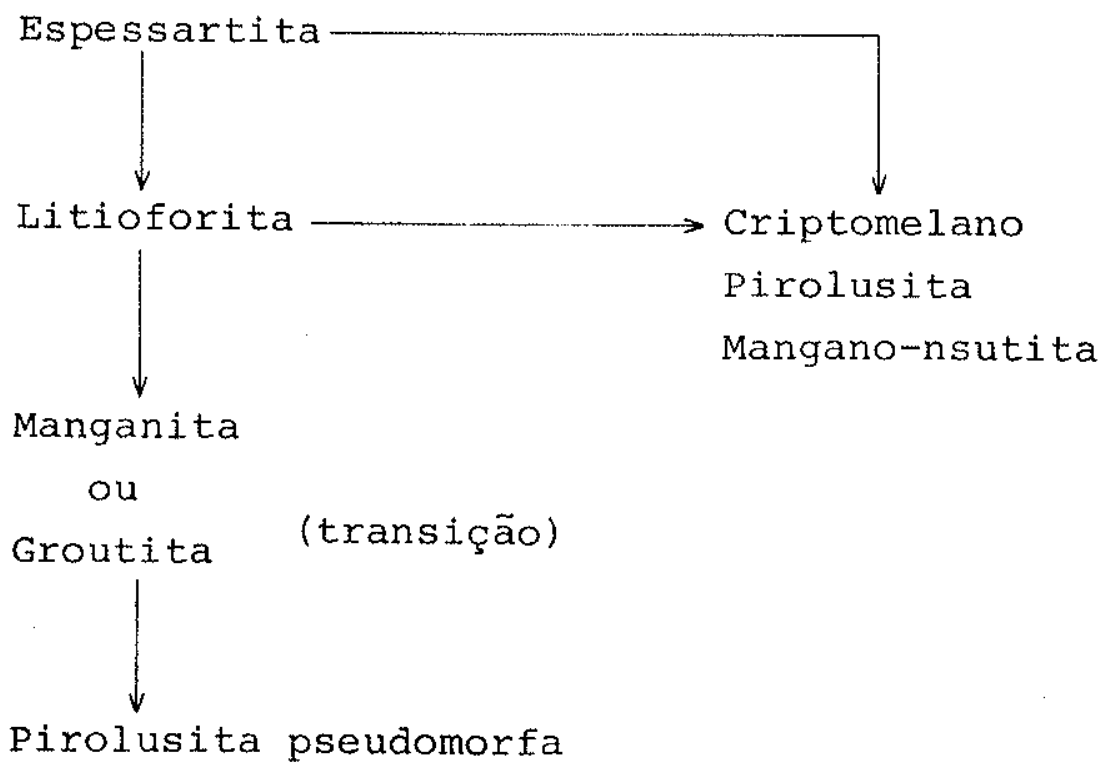

A partir do esquema acima delineado, se conclui que o minério se derivou exclusivamente do intemperismo da espessartita.

Outros fatores confirmam esta assertiva:

a - As zonas de contato são tão alteradas quanto outras partes do depósito.

b - Na composição do protominério não há outro mineral em abundância suficiente para formar os óxidos observados.

c - A quantidade de alumina è alta; o que comprova que - intemperismo se deu a partir de um silicato de alumínio abundante no protominério (Tabelas 15 e 17). 


\subsection{4 - PARAGENESE E SUCESSAO MINERAL}

As paragêneses encontradas no minério são as seguin-

tes:

1 - Litioforita - limonita

2 - Litioforita - pirolusita I

3 - Litioforita - pirolusita I - Criptomelano I mangano-nsutita e óxidos de ferro (goethita ?)

4 - Criptomelano II - pirolusita II - óxidos de ferro

A litioforita è o primeiro mineral a se formar, a partir da espessartita. COUTINHO et al. (1976) afirma, em relação a litioforitas semelhantes, que elas se formam abaixo do nivel freático. SILVA et al. (1963) diz que a formação de uma depressão no limite do intemperismo representa que houve oxidação do protominério abaixo do lençol freático (Perfil A'B' - Mapa Geológico de Lagoa do Riacho).

Com o rebaixamente do nível freático, em zona não saturada de água, a litioforita se transforma em criptomelano e pirolusita, formando as paragêneses 2 e 3 , que compõem grande parte do minērio.

No caso acima referido, a litioforita funciona como estāgio de transição entre a alteração da granada e os outros óxidos de manganês. HÖREN (1953) advoga esta possibilidade para o intemperismo em Morro da Mina (Conselheiro Lafayete, MG) e HOLTROP (1965), estudando os depósitos de manganês do escudo guianense, afirma que em muitos casos a litioforita é o primeiro mineral a se formar, a partir da granada.

As paragêneses litioforita + pirolusita I (2) e pirolusita I + criptomelano I + litioforita + mangano-nsutita (3) são um argumento a favor da afirmação de que a litioforita $\vec{e}$ um elemento de transição entre a granada e os óxidos de manganês.

Tendo em vista o que foi dito anteriormente, indica-se 
QUADRO 5

SUCESSÃO DOS MINERAIS OXIDADOS, DA PROVINCIA MANGANESIFERA DE ARACOIABA-PACAJUS (CE).

PROCESSOS DE FORMAÇÃO

MINERAIS

SUBSTITUIÇÃO

PREENCHIMENTO DE CA-

VIDADES E LATERIZAÇÃO

Litioforita

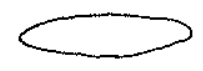

Oxidos de Ferro

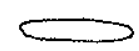

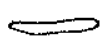

Criptomelano I

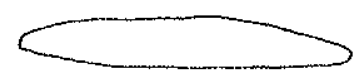

Pirolusita I

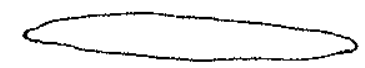

Mangano-Nsutita

$\underset{\sim}{\longrightarrow}$

Criptomelano II

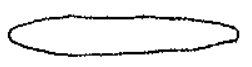

Pirolusita II

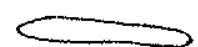


para a fase secundária a seguinte sucessão geral: Litioforita $\rightarrow$ criptomelano $I \rightarrow$ mangano-nsutita $\rightarrow$ pirolusita $I+$ criptomelano II $\rightarrow$ pirolusita II. Na realidade, hä simultaneidade na formação de minerais conforme Quadro 5 (pág. 116).

Teoricamente pode existir mais de uma geração de $1 i-$ tioforita, jā que pode ter havido tambēm mais de uma mudança de nível de base local de erosão que modificou concomitantemente o nível freātico đa região. Esta distinção, na prática, è difícil de ser feita, por falta de critérios.

$$
9 \text { - QUALIDADE E QUANTIDADE DO MINERIO }
$$

\section{1 - QUALIDADE DO MINERIO}

A rocha manganesífera (Gondito) da provincia manganesifera de Aracoiaba-Pacajūs se divide, quanto ao teor, em três tipos:

1 - Uma rocha pouco alterada, cujo teor se situa entre $1 \%$ a $13 \%$ de Mn e que constitui o protominërio propriamente dito.

2 - Uma rocha mais alterada cujo teor se situa entre 18 e $38 \%$ de Mn e que constitui o minério da região.

3 - Uma rocha medianamente alterada, cujo teor oscila entre 13 e $18 \%$ de $M n$ e que constitui a fase de transição de intemperismo entre o protominério e o minério.

Normalmente estes três tipos, que correspondem a três intensidades de intemperismo, ocorrem lado a lado.

o tipo 1 não tem valor econômico nem mesmo a prazo longo e representa $9 \%$ do conjunto.

o tipo 3, embora de baixo teor, é levado em consideração para cálculo de teor médio, jā que ele está sempre asso- 
ciado ao tipo 2 e representa $27 \%$ do conjunto.

O tipo 2 representa $50 \%$ do conjunto e juntamente com - tipo 3 constitui $77 \%$ do material manganesifero. Os tipos 2 e 3 têm um teor médio de $23 \%$ de Mn conforme cálculo anexo à Tabela 14. Calculou-se tambëm o desvio padrão de 3,5, a partirda mëdia, a fim de servir como um dado para possíveis comparações com outras ocorrências. Estas comparações não são feitas aqui por falta de outros dados de desvio padrão na literatura (Tabela 14).

As Tabelas 15,16 e 17 mostram respectivamente mëdias de $5,3,4,1$ e $3,9 \%$ de $\mathrm{Fe}$. O normal de uma ocorrência rica em Mn situa-se entre 6 e 7 (GONÇALVES \& SERFATY, 1976).

o teor de $\mathrm{SiO}_{2}+\mathrm{Al}_{2} \mathrm{O}_{3}$ varia entre 24 e 54 응 para o minério de teor tipo 2. Este intervalo de variação situa-se muito acima dos teores aceitāveis para minério metalúrgico (12\%) e para minério químico (6\%), conforme padrões tabulados por GONÇALVES \& SERFATY,(Op.Cit.).

o valor médio de $0,05 \%$ de $\mathrm{p}$ (Tabelas 15,16 e 17) está dentro dos valores normais de aproveitamento, cujo mäximo aceitável é igual a $0,3 \%$.

Os teores de $\mathrm{Pb}+\mathrm{Cu}+\mathrm{Zn}$ (entre 0,015 e 0,004\%),conforme Tabela 18 , estão dentro dos padrões de uso (GonçALVES \& SERFATY, Op.Cit.).

Conforme especificações do mercado (DNPM, 1978), - minërio da província de Aracoiaba-pacajús (CE), em especial o de Serragem e Lagoa do Riacho, é de baixa qualidade. Isto é muito normal para depósitos de óxidos de manganês que se derivam exclusivamente de alteração de espessartita. Para este caso, HOLTROP (1965) indica um teor médio sempre abaixo de $30 \%$ de $\mathrm{Mn}$. Deste modo o minério não se enquadra como "tipo metalürgico de baixo grau", devido ao baixo teor de Mn e alta percentagem de $\mathrm{Al}_{2} \mathrm{O}_{3}+\mathrm{SiO}_{2}$; nem se enquadra como "tipo químico ou eletrolitico", que exigem teores de $\mathrm{MnO}_{2}$ entre $75 \%$ e $85 \%$

(GONÇALVES \& SERFATY, Op.Cit.). 
TABELA 14

TABULAÇÃO DE DADOS OBTIDOS DO ANEXO III PARA CÁLCULO DE MEDIA (X) E

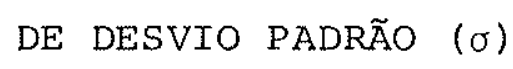

$\begin{array}{cccccr}\begin{array}{c}\text { CLASSES } \\ \text { TEOR EM } \\ \left(\frac{\circ}{6}\right)\end{array} & \begin{array}{c}\text { FREQUENCIA } \\ \text { RELATIVA } \\ (\mathrm{f} j)\end{array} & \begin{array}{c}\text { FREQUENCIA } \\ \text { RELATIVA } \\ \text { ACUMULADA }\end{array} & \mathrm{Xj} & \mathrm{fj} \cdot \mathrm{Xj} & (\mathrm{Xj}-\overline{\mathrm{X} n})^{2} \\ 8-13 & 9,24 & 9,24 & 10,50 & 97,02 & 152,27 \\ 13-18 & 26,76 & 36,00 & 15,50 & 414,78 & 53,87 \\ 19-22 & 21,82 & 57,82 & 20,50 & 447,31 & 5,47 \\ 23-27 & 20,81 & 78,63 & 25,50 & 530,65 & 7,07 \\ 28-32 & 11,47 & 90,10 & 30,50 & 349,83 & 58,67 \\ 33-37 & 8,58 & 98,68 & 35,50 & 384,59 & 160,27 \\ 38-42 & 0,00 & 98,68 & 40,50 & 000,00 & 311,87 \\ 43-47 & 1,32 & 100,00 & 45,50 & 60,06 & 513,47 \\ & 100,00 & & & 2.284,34 & 1.262,96\end{array}$

Cảlculo da Média:

$$
\begin{aligned}
& \overline{\mathrm{X}}_{n}=\text { mëdia } \\
& \overline{\mathrm{X}}_{n}=\frac{1}{\sum \mathrm{fj}} \sum_{j=i} \mathrm{fj} \cdot \mathrm{xj} \\
& \overline{\mathrm{X}}_{n}=\frac{1}{100} \sum_{j=i}^{\mathrm{n}} \mathrm{fj} \cdot \mathrm{Xj} \\
& \overline{\mathrm{X}}_{n}=\frac{1}{100} 2284,34 \\
& \overline{\mathrm{X} n}=22,84 \text { \% de Mn }
\end{aligned}
$$

Cálculo do Desvio Padrão $(\sigma)$

$$
\begin{aligned}
\sigma & =\text { desvio padrão } \\
\sigma^{2} & =\frac{1}{\sum \mp j} \Sigma(x j-\bar{x} n)^{2} \\
\sigma^{2} & =\frac{1}{100} \cdot 1262,96 \\
\sigma^{2} & =12,62
\end{aligned}
$$$$
\sigma=3,55
$$ 


\section{TABELA 15}

VALORES DE Mn/Fe E DE $\mathrm{SiO}_{2}+\mathrm{Al}_{2} \mathrm{O}_{3}$ DE P PARA O MINERIO DA PROVINCIA ARACOIABA PACAJÚS (CE).

\begin{tabular}{|c|c|c|c|c|c|c|c|}
\hline NQ DE ORDEM & $\mathrm{Mn}$ & $\mathrm{Fe}$ & $\mathrm{Mn} / \mathrm{Fe}$ & $\mathrm{SiO}_{2}$ & $\mathrm{Al}_{2} \mathrm{O}_{3}$ & $\mathrm{SiO}_{2}+$ & $\mathrm{P}$ \\
\hline 1 & 23,2 & 4,80 & 4,8 & 21,1 & 10,9 & 32,0 & 0,22 \\
\hline 2 & 13,1 & 3,90 & 3,2 & 35,5 & 10,9 & 46,4 & 0.03 \\
\hline 3 & 35,6 & 4,40 & 7,9 & 13,4 & 10,7 & 24,1 & 1,07 \\
\hline 4 & 28,8 & 5,40 & 5,3 & 15,4 & 11,0 & 26,4 & 0,07 \\
\hline 5 & 15,1 & 5,90 & 2,5 & 41,8 & 12,2 & 54,0 & 0,76 \\
\hline 6 & 8,6 & 7,50 & 1,1 & 47,7 & 13,8 & 61,5 & 0,93 \\
\hline $\begin{array}{c}\text { MEDIA } \\
\text { ARITMETICA }\end{array}$ & 20,7 & 5,30 & 4,1 & 29,1 & 11,5 & 40,6 & 0,51 \\
\hline
\end{tabular}

Tabela construía a partir de dados compilados de BRAGA et al (1977). 
TABELA 16

RESULTADOS DE ANÁLISES QUIMICAS DO MINERIO DE MANGANES DA PROVINCIA DE ARACOIABA-PACAJUS (CE) DE ACORDO COM A OCORRENCIA ()

OCORRENCIA

1 - Sítio Casé

2 - Curral Velho

3 - Curral Velho

4 - Lagoa da Pedra

5 - Lagoa da Pedra

6 - Fiūza

7 - Fiúza

8 - Fiúza

9 - Serragem

10 - Serragem

11 - Canafístula

12 - Lagoa dos Porcos

13 - Lagoa dos porcos

14 - Bolas

15 - Alto do Urubu

16 - Alto preto

17 - Açudinho

18 - Lagoa Bonita

19 - Sitio Açude

Mēdia Aritmëtica
$\begin{array}{llllll}\mathrm{Mn} & \mathrm{Fe} & \mathrm{SiO}_{2} & \mathrm{~F} & \mathrm{~S} & \mathrm{H}_{2} \mathrm{O}\end{array}$

$22,5 \quad 3,7 \quad 42,6 \quad 0,05 \quad 0,05 \quad 0,5$

$\begin{array}{llllll}27,5 & 2,5 & 46,0 & 0,07 & 0,02 & 0,6\end{array}$

$27,0 \quad-\quad 35,2 \quad 0,09 \quad 0,02 \quad 1,3$

$\begin{array}{llllll}25,0 & 3,6 & 37,6 & 0,04 & 0,04 & 0,6\end{array}$

$\begin{array}{llllll}16,6 & - & 30,3 & 0,03 & 0,03 & 6,2\end{array}$

$31,3 \quad-\quad 13,9 \quad 0,06 \quad 0,03 \quad 1,9$

$\begin{array}{llllll}24,5 & 3,7 & 37,6 & 0,03 & 0,03 & 0,5\end{array}$

$\begin{array}{llllll}27,5 & - & 29,7 & 0,07 & 0,03 & 0,8\end{array}$

$16,5 \quad-\quad 42,2 \quad 0,03 \quad 0,03 \quad 2,9$

$\begin{array}{llllll}42,3 & 2,9 & 8,6 & 0,04 & 0,02 & 2,0\end{array}$

$28,0 \quad 4,9 \quad 19,9 \quad 0,04 \quad 0,04 \quad 4,3$

$20,8 \quad-\quad 22,7 \quad 0,04 \quad 0,02 \quad 5,9$

$\begin{array}{llllll}42,8 & 4,2 & 6,2 & 0,06 & 0,03 & 1,9\end{array}$

$25,0 \quad 2,9 \quad 44,3 \quad 0,10 \quad 0,03 \quad 1,4$

$\begin{array}{llllll}34,0 & 2,5 & 32,0 & 0,08 & 0,03 & 1,1\end{array}$

$\begin{array}{llllll}34,0 & 6,1 & 15,0 & 0,09 & 0,03 & 4,5\end{array}$

$\begin{array}{llllll}25,0 & 2,9 & 38,6 & 0,07 & 0,04 & 0,9\end{array}$

$22,4 \quad 6,3 \quad 35,4 \quad 0,09 \quad 0,04 \quad 1,5$

$\begin{array}{llllll}20,4 & 7,6 & 30,3 & 0,03 & 0,05 & 1,9\end{array}$

$27,0 \quad 4,1 \quad 30,0 \quad 0,05 \quad 0,03 \quad 2,14$

Dados extraídos de MORAES (1974). 
TABELA 17

RESULTADOS DE ANALISES QUIMICAS DO MINERIO DE SERRAGEM E LAGOA DO RIACHO

\begin{tabular}{|c|c|c|c|c|c|c|}
\hline $\begin{array}{l}\text { NQ DE } \\
\text { ORDEM }\end{array}$ & $\mathrm{SiO}_{2}$ & $\mathrm{Fe}$ & $\mathrm{Al}_{2} \mathrm{O}_{3}$ & $\mathrm{P}$ & $\mathrm{Mn}$ & UMIDADE \\
\hline 1 & 29,02 & 3,73 & 11,04 & 0,05 & 32,20 & 50,95 \\
\hline 2 & 36,88 & 8,37 & 7,78 & 0,07 & 23,90 & 3,67 \\
\hline 3 & 20,82 & 2,81 & 7,48 & 0,06 & 40,40 & 2,94 \\
\hline 4 & 66,30 & 2,60 & 7,01 & 0,03 & 12,00 & 3,03 \\
\hline 5 & 68,88 & 6,70 & 10,56 & 0.02 & 3,00 & 0,62 \\
\hline 6 & 70,74 & 2,88 & 7,65 & 0,02 & 9,00 & 2,81 \\
\hline 7 & 55,74 & 3,01 & 7,64 & 0,05 & 17,90 & 3,02 \\
\hline 8 & 31,86 & 3,53 & 6,28 & 0,06 & 33,00 & 3,63 \\
\hline 9 & 49,42 & 3,88 & 14,01 & 0,08 & 18,00 & 1,32 \\
\hline 10 & 54,24 & 1,50 & 6,45 & 0,06 & 22,38 & 0,68 \\
\hline $\begin{array}{c}\text { MEDIA } \\
\text { ARITMETICA }\end{array}$ & 48,39 & 3,90 & 7,82 & 0,05 & 21,17 & \\
\hline
\end{tabular}

Executado pelo Laboratório de análises minerais do Departamento de Minas do Estado do Ceará. 
TABELA 18

ELEMENTOS TRAÇOS NO MINERIO DE LAGOA DO RIACHO E SERRAGEM NO MUNICIPIO DE ARACOIABA (CE) - (ppm)

\begin{tabular}{c|rrrrrrrr}
\hline $\begin{array}{l}\text { No DE } \\
\text { ORDEM }\end{array}$ & $\mathrm{Pb}$ & $\mathrm{Cu}$ & $\mathrm{Ni}$ & $\mathrm{Zn}$ & $\mathrm{Co}$ & $\mathrm{Cr}$ & $\mathrm{Sr}$ & $\mathrm{Pb}+\mathrm{Cu}+\mathrm{Zn}(\%)$ \\
\hline 1 & 8 & 20 & 330 & 120 & 350 & 80 & 94 & 0,015 \\
2 & 13 & 130 & 560 & 260 & 1000 & 20 & 344 & 0,040 \\
3 & 150 & 350 & 100 & 780 & 165 & 93 & 0,025 \\
4 & 5 & 15 & 15 & 26 & 200 & 70 & 39 & 0,004 \\
5 & 14 & 220 & 150 & 240 & 222 & 20 & 244 & 0,047 \\
6 & 15 & 40 & 350 & 130 & 500 & 50 & 313 & 0,018 \\
\hline
\end{tabular}

Os elementos Sr e Cr foram determinados por tēcnico do laboratörio de Fluorescência de Raios $x$ pertencente ao Centro de Pesquisas Geocronolögicas do Instituto de Geociências da Universidade de São Paulo. Os outros resultados foram obtidos por Absorção Atômíca no laboratório Puriquima (São Paulo). 
Em relatórios técnicos da CPRM, BRAGA (1977) sugere uma prē-lavagem do minério como meio de se conseguir um concentrado rico em Mn. Este processo è perfeitamente exequível, desde que sua execução seja precedida de um estudo experimental para avaliar os aspectos econômicos quanto a reservas e a mercado doméstico.

\section{2 - QUANTIDADE DO MINERIO}

Na ocorrência de serragem foram computadas aproximadamente 110.000 t de minério bruto a 28\% de Mn, de reserva medida. Deste total 52.000 t correspondem a minério rolado (CRUZUL, 1975).

$\mathrm{Na}$ ocorrência de Lagoa do Riacho foram computadas 370.000 t de minério bruto a $27 \%$, como reserva medida (CRUZUL, op.Cit.). Deste total 200.000 t correspondem a minério rolado (Tabela 19).

Considerando todas as ocorrências da província (20) com uma reserva média de 110.000, se estimam 2.200.000 t de minério bruto a 23\% de Mn (Teor mëdio da província).

MORAES (1973), fazendo um cálculo geral para a provincia estimou em $6 \cdot 10^{6}$ t de minério bruto como reserva inferida.

Dos dados acima referidos, se conclui que $50 \%$ da reserva medida em Serragem e Lagoa do Riacho correspondem a minërio rolado. Conforme informações em relatórios de CRUzUL (1975), esta conclusão pode ser extrapolada para toda a província. 
TABELA 19

RESERVAS MEDIDAS DE SERRAGEM E LAGOA DO RIACHO (ARACOIABA - CE) CONFORME RELATORIO INEDITO DE CRUZUL (1975).

\begin{tabular}{l|ccccc}
\hline MINERIO & SERRAGEM & LAGOA DO RIACHO & TEOR EM Mn (\%) \\
\hline Rolado & $50000 t$ & $200000 t$ & 26,5 \\
In situ & $60000 t$ & $170000 t$ & 29,5 \\
Total & $110000 t$ & $370000 t$ & 28,0 \\
\hline
\end{tabular}

10 - COMPARAÇÃO COM OUTRAS OCORRENCIAS

Na India, em Dongri Buzurg (Maharashtra), em zona metamörfica de almandina são encontrados gonditos que se constituem de espessartita, rodonita, tirodita e quartzo (ROY,1968). Esta composição é semelhante ao gondito de Aracoiaba-Pacajús (CE). Apenas o anfibólio não foi determinado especificamente como tirodita e sim como mangano-cumingtonita de maneira geral.

De maneira geral, os depósitos de Aracoiaba-Pacajús têm em comum com os depósitos da India o fato de não ter sido encontrado carbonato no protominério (ROY, 1965), embora presuma-se que tenha existido no depósito original em Aracoiaba-Pacajús.

WRIGHT \& MC CURRY (1970) descrevem uma ocorrência de manganês no norte da Nigéria muito semelhante à do Ceará. O protominërio é constituído de granada de $0,5 \mathrm{~mm}$ de diâmetro dentro 
de fina massa de quartzo equigranular em textura em mosaico.

Existe um depósito em Ghana (Árica) muito semelhante na província de Aracoiaba-Pacajús: situa-se em Nsuta Mine Area cujo protominério é composto de espessartita, rodonita e quartzo e cuja parte oxidada é constituída principalmente de mangano-nsutita, pirolusita, criptomelano e litioforita (ROY, 1965).

Nos depósitos do escudo guianense (Guianas e Brasil) são conhecidos níveis de protominérios (gondito) que são semelhantes aos gonditos de Aracoiaba-Pacajús (HOLTROP, 1965). A diferença estä no fato de que no escudo guianense predominam outras rochas espessartiticas, como maripaitos e rochas espessartíticas, enquanto em Aracoiaba-Pacajús (CE) existe somente o gondito.

As mineralizações em manganês do Estado do Ceará aqui descritas são comparäveis geologicamente aos depósitos de serra do Navio no Amapā e de Conselheiro Lafayete em Minas Gerais. Todos se formaram em ambientes redutores e foram metamorfisados durante o mesmo ciclo tectônico. No entanto, a presumível pequena espessura dos sedimentos carbonáticos originais em Aracoiaba (CE) diferem das grandes espessuras dos sedimentos em Conselheiro Lafayete e em Serra do Navio (Quadro 6). Por esta razão, restaram em Aracoiaba-Pacajūs apenas protominērios silicāticos e nos outros depósitos se formaram protominérios silicáticos e carbonāticos. A conseqtência deste fato é a pouca espessura atual do protominério em Aracoiaba e a ausência de um manto de oxidação mais espesso por falta de carbonato que desencadeie um intemperismo mais completo.

O protominério silicātico de Serra do Navio (Amapá) tem pequena espessura e teor de 15\% (NAGELL, 1961), assemelhando-se assim aos depósitos de Aracoiaba-Pacajús.

No Ceará, as condições tectônicas, caracterizadas por levantamentos epirogenēticos, ensejaram um grande processo de erosão ocasionando grande aplainamento de terreno (BRITO NEVES, 1975). Isto reduziu a profundidade atual de intemperismo (me- 
QUADRO COMPARATIVO ENTRE OS DEPÓSITOS DE MANGANES DE ARACOIABA-PACAJÚS E AS JAZIDAS DE SERRA DO NAITO(AM), MORRO DA MINA (MG) E URANDI (BA)

Critērio para comparação

Idade

Tipo de protominério

Espessura do protominério

Profundidade de oxidação

Teor em Mn (\%)

Teores em $\mathrm{SiO}_{2}$ (\%)

Mineralização primāria metamórfica

Reserva

\begin{tabular}{|c|c|}
\hline $\begin{array}{c}\text { Serra do Navio, } \\
\text { Amapá }\end{array}$ & $\begin{array}{l}\text { Morro da Mina, } \\
\text { Cons. Lafaiete (MG) }\end{array}$ \\
\hline $\pm 2000 \mathrm{~m} . \mathrm{a}$ & $\begin{array}{l}\text { Fim do arqueano } \\
\text { (EBERT, 1963) }\end{array}$ \\
\hline Silico-carbonātico & Silico-carbonätico \\
\hline $30 \mathrm{~m}$ & . \\
\hline $\pm 100 \mathrm{~m}(\mathrm{NAGELL}, 1961)$ & $\begin{array}{c}66 \mathrm{~m} \text { (HÖREN, 1953) } \\
93 \mathrm{~m} \text { (BITTENCOURT) } \\
\text { 1973) }\end{array}$ \\
\hline 45. & 40 a 45 \\
\hline$\stackrel{ \pm 7}{ \pm}$ & $\begin{array}{c}8 \text { a } 17 \\
\text { (BITTENCOURT, 1973) }\end{array}$ \\
\hline Quartzo & Quartzo \\
\hline Carbonato & Carbonato \\
\hline Rodonita & Rodonita \\
\hline Piroxmangita & Piroxmangita \\
\hline Espessartita & Espessartita \\
\hline Tefroita & Tefroita \\
\hline Grafita & Alabandita \\
\hline $\begin{array}{l}32.10^{6} \mathrm{t} \text { (Em 1972) } \\
\text { (GONÇALVES, 1976) }\end{array}$ & $\begin{array}{l}\text { Grafita } \\
5.10^{6} \text { t (ABREU, 1978) }\end{array}$ \\
\hline
\end{tabular}

JAZIDAS
Aracoiaba-
Pacajūs (CE)

\pm 2000 m.a.

Sílico carbonātico
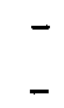

47

3

Mangano-dolomita

Espessartita

Rodonita

Quartzo

(Mina Barreira-

RIBEIRO FILHO, 1968)

$1.10^{5} t$ (GONÇALVES, 1976)

\section{Silicātico $<4 \mathrm{~m}$ $<37 \mathrm{~m}$ \\ $<30$ \\ 30}

Espessartita Rodonita

Mangano-cuming tonita

Quartzo

Pirita e Pirrotita

Grafita

$3.10^{6} \mathrm{t}$ de minério 
nor que $35 \mathrm{~m}$ ); em outras ocorrências e depósitos no Brasil esta profundidade ē relativamente grande (Quadro 6).

o regime de chuva e o clima atuais diferem em muito entre as regiões de Aracoiaba-Pacajūs (Figura 2) e outras regiões de manganês do Brasil. No Ceará predomina o clima semi-ärido e nas outras partes o clima tropical úmido. Mesmo assim, observa-se que o intemperismo dos protominérios silicáticos independe do clima atual, tendo em vista que os resultados são os mesmos quer em Minas Gerais ou Amapá quer no Ceará.

As condições de deposição original em ambiente oxidante na região de Urandi no Estado da Bahia (RIBEIRO FILHO, 1968) diferem das condições de Aracoiaba-Pacajūs. Os depósitos de Urandi, por ter mineralização primāria, na fase metamórfica, de carbonatos e óxidos, diferem muito quanto à paragênese; em Aracoiaba-Pacajūs, a associação é essencialmente silicática.

As demais diferenças podem ser acompanhadas pelo Quadro 6 (pãg.127) onde se fazem correlações entre os depósitos de Serra do Navio (AM), Morro da Mina (MG) e Urandi (BA) em relação aos depósitos de Aracoiaba-Pacajús (CE) .

No Estado do Ceará existem outras áreas de ocorrência de manganês que são semelhantes à ārea de Aracoiaba-Pacajús (CE) : são as ocorrências situadas a noroeste da sede do município de Aracoiaba e as ocorrências do município de Piquet carneiro (Tataíra). Ambas têm em comum os seguintes aspectos:
a - Estão em gondito.
b - Estão situadasvizinhas a falhas transcorrentes.
c - Situam-se estratigraficamente no mesmo nivel (Com- plexo Caicö).
d - Estão vizinhas a províncias pegmatiticas e a ārea de ocorrência de grafita.




\section{1 - CONCLUSOES GERATS}

As principais conclusões deste trabalho são a seguir enumeradas e comparadas com as idéias esboçadas em trabalhos anteriores e resumidos no item 4 .

1 - Os depósitos de manganês da província ora estudada se situam no Complexo Caicó de idade minima de $2.100 \mathrm{~m} . \mathrm{a}$. Esta conclusão baseada nas datações de KAWASHITA et al. (1976), BRITO NEVES (1975) e CORDANI (1974) coincide com a conclusão de BRAGA (1977) e está em desacordo com as afirmações de MANOEL FILHO (1971) e DANTAS (1974).

2 - Os depósitos de manganês são constituídos por gonditos encaixados em um conjunto de granada-quartzito e migmatito-gnaisse. Esta conclusão complementa o que foi dito por MoRAES (1974) e não coincide com as afirmações de COELHO (1957).

3 - Os gonditos, de direção $\mathrm{N} 10^{\circ} \mathrm{W}$ e mergulho de $50^{\circ}$ a $75^{\circ}$ leste, estão associados a núcleos de dobras sinclinais e anticlinais em dobramentos de 2 - ordem (MOODY, 1973) cujos eixos fazem aproximadamente $15^{\circ} \mathrm{NNE}$ com a falha transcorrente de senador Pompeu. Alguns dados de campo e de laboratōrio sugerem que o acamamento original é coincidente com a foliação.

A bibliográfia é omissa sobre este assunto.

4 - Os gonditos são compostos essencialmente de espessartita, quartzo rodonita e mangano-cumingtonita e acessoriamente de grafita, pirita, pirrotita, titanita e pirofanita. Estes minerais estão distribuídos em texturas em mosaico, de inclusão, de limites mütuos e bandeada.

MORAES (1974) se refere à composição do gondito sem citar a rodonita e mangano-cumingtonita. BRAGA et al. (1977)cita rodocrosita como componente do gondito.

Em relação à textura a literatura é omissa. 
5 - As condições de metamorfismo, inferidas a partir do estudo de rochas regionais e encaixantes, são caracterizadas por pressão minima aproximada de $6 \mathrm{~kb}$ e temperatura minima de $600^{\circ} \mathrm{C}$. A fácies metamórfica dominante é a granulítica. Estas conclusões estão em desacordo com as observações de BRAGA (1977) e da CRUzUL (1975) que situam as ocorrências de Mn na fäcies anfibolito e xisto verde respectivamente. Hä, na realidade, uma superposição de fácies anfibolítica, o que comprova a sugestão de BRITO NEVES (1975), segundo a qual houve uma remobilização no ciclo brasiliano.

6 - o depósito é classificado como estratiforme formado a partir de metamorfismo sobre sedimentos arenosos impuros, cuja mineralização foi presumivelmente constituída de carbonatos, quartzo, outros silicatos e sulfetos.

MORAES (1974) sugere que os depósitos são constituídos por lentes paralelas de protominério; isto é comprovado em nosso trabalho. Sobre a composição dos sedimentos originais, não hä referência na literatura.

7 - O conjunto de rochas encaixantes corresponde aproximadamente a unidade 2 de BRITO NEVES (1975).

A base da sequência de rochas é constituída por migmatito-gnaisse, semelhante aos kondhalitos da India e Ceilão (TURNER, 1968).

o topo da sequência de rochas é constituído de gondito. Entre o gondito e o migmatito-gnaisse situam-se almandina-silimanita-quartzito, granada-quartzito e metabasitos entre outras rochas.

Não foram observados os filitos citados por COELHO (1957) .

8 - Muitos fatos comprovam a origem supérgena por alteração exclusiva da espessartita do protominério entre os minerais de manganês:

a - Texturas pós-deposicionais (Textura reliquiar, 
textura reliquiar zonada, textura de borda,etc.).

$b$ - Existência de gondito com teor em óxido intermediārio entre o minério e o protominërio.

c - Existência de apófises de óxidos no protominërio.

d - Existência de óxidos de manganês preenchendo fraturas transversais ao acamamento das rochas, indicando controle da gravidade sobre as soluções enriquecidas.

e - predominância de espessartita e ausência de carbonatos no protominërio.

9 - o minério é composto de litioforita, criptomelano, pirolusita e mangano-nsutita como minerais-minério e de espessartita, quartzo, piroxenóide e anfibölio como ganga.

A literatura fala somente de pirolusita e criptomelano sem comprovação por análise de raios $\mathrm{X}$.

10 - Os fatores que mais influenciaram o intemperismo local foram:

a - A natureza do protominério com predominância de espessartita e ausência de carbonato.

b - o controle estrutural por meio de fraturamentos e cisalhamentos ocasionados pela reativação da faIha de Senador Pompeu.

C - A situação fisiogrăfica aplainada em função de levantamentos epirogenéticos (BRITO NEVES, 1975).

11 - o teor médio da provincia é $23 \%$ de Mn. Alguns depósitos isoladamente tem um teor médio em torno de $28 \%$ de $\mathrm{Mn}$. A tonelagem para toda a provincia é estimada em $3.10^{6}$ t de minério bruto. Estes dados se aproximam dos da literatura.

12 - Pelo Quadro 7 acompanha-se a evolução das paragêneses sedimentar, metamörfica e supergênica. 


\section{QUADRO 7}

EVOLUÇÃO DAS PARAGENESES SEDIMENTAR, METAMORFICA E SUPERGÊNICA DO GONDITO DA PROVINCIA MANGANESIFERA DE ARACOIABA-PACAJUS, (CE).

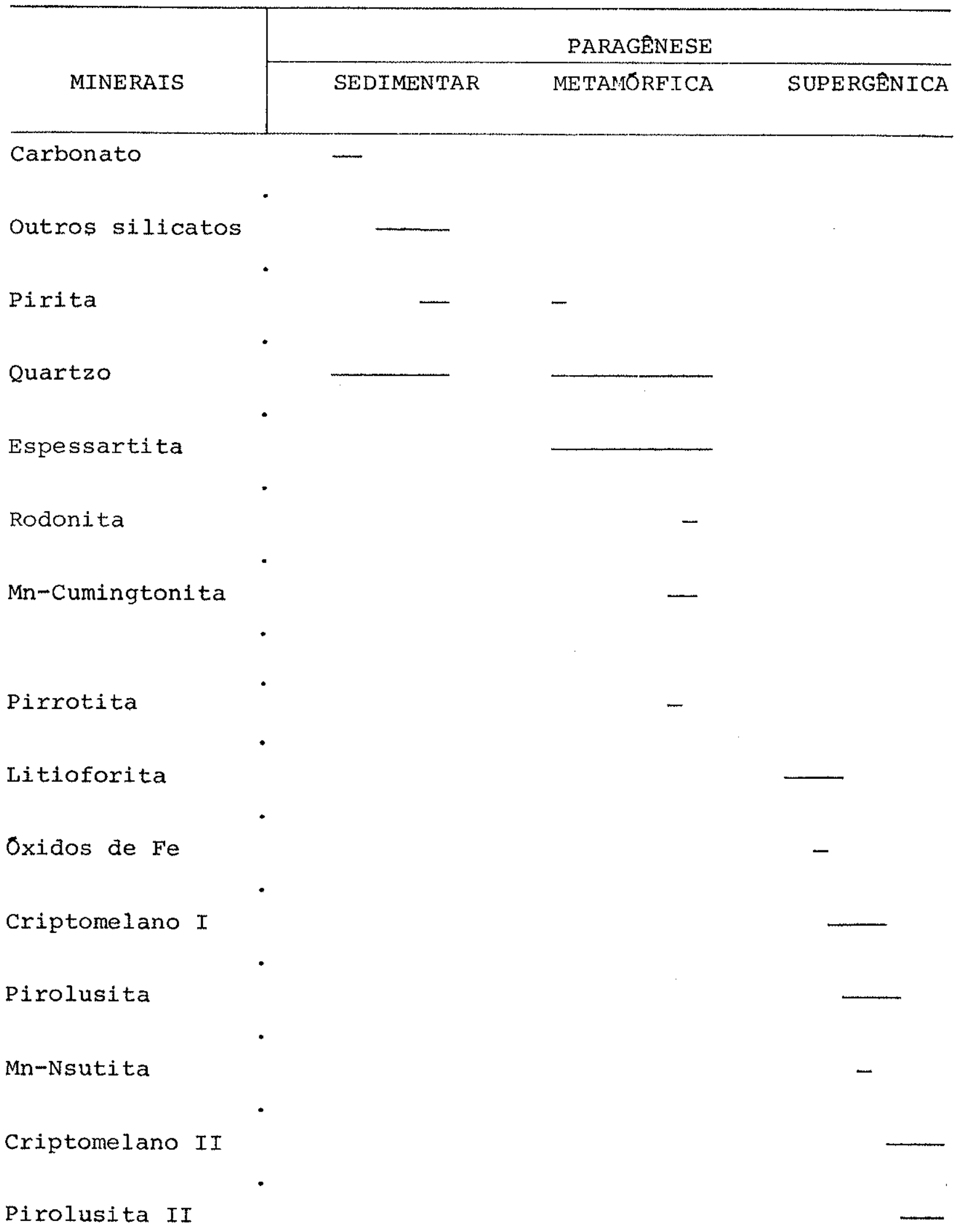


Pelo Quadro 5, observa-se que 65 a $70 \%$ do minério foi formado por processo de substituição e o restante por processo de preenchimento de cavidades e laterização.

A literatura é omissa neste assunto.

13 - O minērio é classificado em minērio "in situ" e minério residual. O minério residual constitui $50 \%$ da reserva total.

Estes dados são referidos em CRUzuL (1975).

14 - o gondito tem três estágios de alteração:

a - Uma rocha pouco alterada - 1 a 138 de Mn.

b - Uma rocha medianamente alterada - 13 a $18 \%$ de $\mathrm{Mn}$.

c - Uma rocha muito alterada - 18 a $38 \%$ de $\mathrm{Mn}$.

o intemperismo se iniciou pelo processo de fraturamento, com a formação de óxidos de manganês por processos de substituição e preenchimento de cavidades; e terminou com a formação de esferas concêntricas constituídas de óxidos de manganês formadas por processo de laterização.

A profundidade de intemperismo varia de 23 a $37 \mathrm{~m}$.

\section{2 - CONCLUSÃO FINAL}

Observa-se pelo que foi resumido nas conclusões gerais que o objetivo principal desta tese foi alcançado: a caracterização paragenētica e textural do protominério oxidado. A partir desta caracterização foram delineados a gênese e o intemperismo.

Sobre a eventual possibilidade de aproveitamento econômico, que é o objetivo secundārio desta tese, são acrescentados novos dados de análises químicas que são cotejados com dados de referência. Por outro lado, são feitas comparações com jazidas conhecidas. 
Em vista das considerações feitas quanto à qualidade do minério, classifica-se o material de Serragem e Lagoa do Riacho como minērio de baixa qualidade, cuja reserva é restrita. seu aproveitamento só é possível se houver uma mudança de mentalidade quanto à utilização dos recursos minerais de pequeno porte, orientando-a no sentido de suprimento de pequenas áreas em investimentos siderúrgicos pröximos das jazidas.

o mesmo pode ser dito sobre todo o minério da província manganesifera de Aracoiaba-Pacajús (CE) .

Continua inexplicada a origem do manganês que se depositou nos sedimentos impuros. Este assunto só será esclarecido com um maior conhecimento da geologia regional do nordeste do Estado do Ceará. 


\section{3 - REFERENCIAS BIBLIOGRAFICAS}

ABRECHET,I. \& PETERS,Tj. Hidrothermal sintesis of pyroxenoids in the sistem $\mathrm{MnSiO}_{3}-\mathrm{CaSiO}_{3}$ at $\mathrm{Pf}=2 \mathrm{~Kb}$. Contr.Miner.Petrol., 50(4): 241-6, 1975 .

ABREU,S.F. Recursos minerais do Brasil. 2.ed. São Paulo, Edgard Blucher, 1973. v.2. 754p.

ALMEIDA,F.F.M. Origem dos protominérios de ferro e manganês de Urucum. Rio de Janeiro, DGM/DNPM, 1946. (bol.119).

ANDRADE,G.O. \& LINS,R.C. Introdução à morfoclimatologia do Nordeste do Brasil. Arq. Inst. Cien. Terra, 3(4):17-28, 1965.

AMERICAN SOCIETY FOR TESTING MATERIAL (ASTM). X-ray date file. Philadelphia, 1965.

AZAROFF,L.V. \& BUERGER,M.J. The powder method in X-ray crystallography. New York, Mac-Graw-Hi11, 1958. 342p.

BARBOUR, A.P. Resumo da geologia dos depösitos de manganês de Serra do Navio. Rio de Janeiro, ICOMI S/A, 1965. 10p. (Inēdito).

BASTIN,E.S. Interpretation of ore textures. New York, The Geological Society of America, 1950. 100p. (Memoir 45).

BELLO,R.M.S. et al. Ocorrência simultânea de piroxmangita e rodonita em protominērios de manganês brasileiro. Congresso Brasileiro de Geologia, 299. Belo Horizonte, 1976. (Resumo).

- Condições de metamorfismo de Buritirama (PA) e Serra do Navio (AM). São Paulo, 1978. 81p. (Dissertação de Mestrado - Instituto de Geociências, USP). 
BITTENCOURT,A.V.L. Contribuição ao estudo genético do minério de manganês de Conselheiro Lafaiete (MG). São Paulo, 1973. 153p. (Dissertação de Mestrado- Instituto de Geociências, USP ).

BRAGA,A.Q.G. et al. Projeto Fortaleza - Convênio DNPM/CPRM. Recife, CPRM, 1977. v.1-2. (Relatório inédito).

BRITO NEVES,B.B. Regionalização geotectônica do pré-cambriano nordestino. São Paulo, 1975. 198p. (Tese de Doutorado Instituto de Geociências, USP).

CAMARGO,W.G.R. \& MADURETRA (FILHO), J.B. New diagrams for physical determination of garnets. An.Acad.Bras.Cien. $, \underline{48}(1): 57$ -68 . 1976 .

CASTRO,L.O. Study of the manganese ores of the serra do Navio District, Amapā, Brazil. Bol.Soc.Bras.Geol., 12 (1 e 2):5-35, 1963.

CHAKRABORTY,K.L. Relationship of anthophillite, cummingtonite and mangano-cummingtonite in the metamorphosed Wabush Iron-Formation Labrador. Canad. Miner., $\underline{7}(5): 738-50,1963$.

COELHO,F.C.P. Manganês do Estado do Cearā. Relatōrio Anual do Diretor, DGM/DNPM. Rio de Janeiro, DNPM, 1957. p.60-1.

CORDANI,U.G. Comentārios sobre as determinações geocronológicas disponiveis nas folhas Jaguaribe e Fortaleza (f.SB-24 e f.SA25). In: DANTAS,J.R.A. Carta geológica do Brasil ao milionésimo. Rio de Janeiro, DNPM, 1974. p.59-74.

COUTINHO,J.M.V. et al. Mineralogical study of the main manganese carbonate silicate protores (queluzites) from Brazil and their weathering. International Geological Congress, $25^{\text {th }}$. Sydney, Austrālia, 1976. (Abstracts no 3). p. 764-5. 
COMPANHIA SIDERURGICA CRUZEIRO DO SUL (CRUZUL). Relatōrios de pesquisa das āreas de manganês de Aracoiaba-pacajūs (CE). Rio de Janeiro, 1975. (Inéditos).

DANTAS,J.R.A. Texto explicativo da carta geológica do Brasil ao milionésimo (f.SB-24 e f.SA-25). Rio de Janeiro, DNDM, 1974. $95 \mathrm{p}$.

DERBY,O.A. On the manganese ore deposits of the Queluz-Lafaiete (MG), Brazil. Am.J.Sci., I62(67-72):18-32, 1901.

- On the original type of the manganese deposits of the Queluz District (MG), Brazil. Am.J.Sci., 25(147):213-6,1908.

DEPARTAMENTO NACIONAL DA PRODUÇÃO MINERAL (DNPM). Boletim de preços. Brasilia, MME/DNPM, Nov.-dez., 1978. no27. 42p.

DE VILLIERS,P.R. The geology and mineralogy of the Kalahari Manganese - Field North of Sishen, Cape Province. Johanesburgo, Geological Survey Republic of the South Africa, 1971. 84p. (Memoir 59).

DE WAARD, D. The occurrence of garnet in the Granulite-Facies Terrane of the Adirondack Highlands. J.Petrol., 6(1):165-91, 1965.

DORR,J.V.N. Manganese and iron deposits of Morro do Urucum, Mato Grosso, Brazil. 2ed. Washington, U.S.G.S., 1945. p.1-47. (Bulletim no 946A).

DORR II, J.V. et al. Manganese deposits of the Serra do Navio District - Territory of Amapä, Brazil. Washington,U.S.G.S., 1949. 51p. (Bulletim no 964A).

The manganese deposits of Minas Gerais, Brazil. Congresso International de Geologia,208. México, 1956. (Simposium del Manganeso) t.3. p.3-13. 
DORR II,J.V. et al. Primary manganese ores. Congresso Brasileiro de Geologia, 22.. Belo Horizonte, 1968. (Resumo).

EBERT, H. The manganese-bearing Lafaiete - Formation as a guide -horizon in the pré-cambrian of Minas Gerais. An. Ac. Bras. Cien. , 35 (4):545-59, 1963.

- Ocorrências de fäcies granulíticas no sul de Minas Gerais e em áreas adjacentes, em dependência da estrutura orogênica (hipótese sobre a origem). An.Ac.Bras.Cien. ,40:215$29,1968$.

FLEISCHER, M. \& RICHMOND,W.E. The manganese mineralogy: a preliminary report. Econ.Geol. $38(4): 269-86,1943$.

GONÇALVES,E. Manganês de Maraū. Congresso Brasileiro de Geologia, 269. Belēm, 1972. (boletim no 1). p.50-51.

GONÇALVES,E. \& SERFATY,A. Perfil Analitico do Manganês. Rio de Janeixo, DNPM, 1976. 149p. (Boletim no 37).

GUICHARD,E. Les sols du bassin du Rio du Jaguaribe, Bresil. Paris, ORSTOM, 1970. 156p.

GUIMARÃES,D. Gênese dos minērios de manganês. An. Ac. Bras. Cien., I 1 (4):171-2, 1929.

Gênese dos depósitus de minêrio de manganês do centro de Minas Gerais. Bol. DNPM/SFPM, 8:45-68, 1935.

HEINRICH,E.W. Petrografia Microscöpica. Barcelona, Omega, 1960. $320 \mathrm{p}$.

HERTZ,N. \& BANERJEE, S. Amphibolites of the Lafaiete, Minas Gerais and Serra do Navio manganese deposits, Brazil. Econ. Geol., 68(8):1289-96, 1973. 
HOLTROP,J.F. The manganese deposits of the Guiana shield Econ. Geol., 60 $(6): 1185-212,1965$.

HÖREN, A. The manganese mineralization at the Merid Mine, Minas Gerais, Brazil. Massachusetts, 1953. 224p. (Tese de doutorado - Division of Geological Sciences, Haward University).

JOINT COMMITTEE ON POWDER DIFERACTION STANDARDS (JCPDS) IndeX (inorganic) to the powder diffraction file. Pennsylvania, 1971. 1322p.

KAWASHITA, $K$. et al. The behavior of solid - source mass spectrometer with glas tube and age determination on some rocks from the state of Ceara (Brazil). An.Ac.Bras.Cien., 48(1):79$-86,1976$.

KEGEL,W. A estrutura geológica do Nordeste do Brasil. Rio de Janeiro, DGM/DNPM, 1965. 47p. (Boletim no 227).

KING,L.C. A geomorfologia do Brasil Oriental. Rev.Bras.Geog., $18(2): 147-256,1956$.

KRAUSKOPF,K.B. Separation of manganese from iron in sedimentary processes. Geoch. Cosmoch. Acta, 12 (1-2):61-84, 1957.

KRUMBEIN,W.C. \& GARRELS,R.M. Origin and classification of sediments in terms of $\mathrm{pH}$ and oxidation-reduction potencials. J.Geol. 60 (1): $1-33,1952$.

LEINZ,V. Estudo genëtico do minērio da Serra do Navio, Território do Amapá. An.Ac.Bras.Cien., 20 (2):211-21, 1948.

LOCZY,I. \& LADEIRA,E.A. Geologia estrutural e introducão à geotectônica. São Paulo, Edgaxa Blucher/CNPq, 1976. 528p.

MABESOONE,J.M. \& CASTRO,C. Desenvolvimento geomorfológico do Nordeste brasileiro. Recife, Sociedade Brasileira de Geologia - Nücleo Nordeste, 1975. p.5-36. (Boletim no 3). 
MACHADO, R. Geologia e gênese do manganês de Bandarra, municipio de Jacaraci (BA). São Paulo, 1977. 109p. (Dissertação de Mestrado - Instituto de Geociências, USP).

MADUREIRA (FILHO), J.B. Novos diagramas para determinação de granadas. São Paulo, 1972. 51p. (Dissertação de Mestrado - Instituto de Geociências, USP).

MANOEL (FILHO), J. Inventário hidrogeolögico do Nordeste (Jaguaribe-NE, f.10). Recife, Sudene, 1971. 343 p.

MELFI,A.J. \& PEDRO,G. Etude sur l'alteration expërimentale de silicates manganesifèxes et la formation exogène des gisements de manganèse. Bul1. Groupe franç. Argiles, 24:91-105, 1973.

MELFT,A.J. \& BITTENCOURT,A.V.L. Evolução superficial das rochas de Conselheiro Lafaiete (MG). Rev.Bras.Geoc., 5(2):85-98, 1975.

MELO,A.A. et al. A tectōnica linear no Estado do Ceará. Congresso Brasileiro de Geologia, 30\%. Recife, 1978. (Anais) v.I. p. 393-407.

MENHERT, K.R. Migmatites and the origin of granitic rocks. 2ed. Amsterdan, Elsevier, 1971. 405p.

MIYASHIRO,A. \& SHIDO,F. Progressive compositional change of garnet in metapelite. Lithos, $6(1): 13-20,1973$.

MOODY,J.D. Petroleum exploration aspects of wrench fault tectonics. Am.Assoc.Petr.Geo1., 57(3):449-76, 1973.

MOODY,J.D. \& HILL,M.J. Wrench fault tectonics. Bull.Geol.Soc. Am., 67 (3):1207-46, 1956 .

MORAES,J.F.S. Projeto Ferro/manganês - Convênio Departamento de Minas do Estado do Ceará - CPRM. Recife, CPRM, 1974. 126p. (Relatório inédito). 
MORAES,J.F.S. \& CAMPOS,M. Projeto de levantamento de recursos minerais do Estado do Ceará (Programa Minerais Industriais) Convênio Departamento de Minas do Estado do Cearä/CPRM. Recife, CPRM, 1973. v.1 e 2. 327p. (Relatório inédito).

NAGEL, I.R.H. Geology of the Serra do Navio Manganese District,Bra zi1. Econ.Geol. , 57(4):481-92, 1962 .

NAGEL,L.R.H. \& SILVA,A.R. O carbonato como protominërio no distri to de Serra do Navio. Bol.Soc.Bras.Geol. 57 (2):53-59,1961.

UDMAN, O.H. Morro da mina manganese deposit and its protore. Eng.Min.Met. , 21 (122):57. 1955.

OLIVEIRA,E. Gênese dos minērios de manganês. An.Ac.Bras.Cien., $1(4): 173-8,1929$.

ORCEL, M.M.J. \& PAVLOVITCH,St. Les caratēres microscopiques des oxides de manganèse et des manganites naturels. Bull. Soc. Franç.Min., 54:108-79, 1931.

PARK,C.F.Jr. Manganese ore deposits of the Serra do Navio district, Territory of Amapā, Brazil. Intern.Geol.Cong., 20 . Mëxico, 1956. (Simposium del Manganeso). t.3. p.347-76.

PARK, C.F. et al. Notes on the manganese ores of Brazil. Econ. Geol. $\underline{46}(1): 1-22,1951$.

PETERS, T. et al. Petrogenetic grids from experimental date in the system Mn-Si-C-O-H. Rev.Bras.Geoc. , 4 (1):15-26, 1974.

PIRES,F.R.M. et al. Gonditos na região de Pouso Alegre (MG). Min.Met. $52(312): 237-9$, 1970 .

RAMDOHR, P. Pyrolusite. In: - The ore minerals and their intergrowths. 3.ed. Oxford, Pergamon Press, 1969. p. $1001-5$. 
RIBEIRO (FILHO), E. Geologia da região de Urandi e das Jazidas de manganês de Pedra Preta, Barreiro dos Campos e Barnabë (BA). São Paulo, 1968. 83p. (Tese de Livre-Docência - Faculdade de Filosofia, Ciências e Letras, USP).

Geoloqia da região de Urandi, Estado da Bahia. Bol. Inst.Geoc., USP. , 4:87-95, 1973.

- Texturas indicativas de gênese de manganês da região de Urandi, Estado da Bahia. International Geological Congress. 25 th. Sydney, Austrälia, 1976. (Abstracts no 3).

RIBEIRO (FILHO),E. \& VALARELII,J.V. Rondonita e espessartita de Urandi, Bahia. Ciência e Cultura, 18(2):215-6, 1966.

ROUTHIER, P. Les gisements mëtallifères, geologie et principes de recherche. Paris, Masson, 1963. t.1. 867p.

ROY, S. Comparative study of the metamorphosed manganese protores of the world, the problem of the nomenclature of the gondites and kođurites. Econ.Geol., 60 (6):1238-60, 1965.

- Mineralogy of the different genetic types of manganese deposits. Econ.Geol. $63(7): 760-86,1968$.

SANTOS,E.J. et al. Texto explicativo do mapa geológico preliminar do Estado do Cearā: Compilação e Interpretação,escala 1/5.000.000. Recife, Departamento de Minas do Estado do ceará/CPRM, 1972. (Inédito).

SCARPELLI,W. Aspectos genéticos e metamörficos das rochas do Distrito de Serra do Navio. Anais da 6 a Conferência GeolögiCa das Guianas. Rio de Janeiro,DGM/DNPM, 1966. p.37-56. (Avulso no 41). 
SCARPELLI,W. The Serra do Navio manganese deposits (Brazil). Earth Sciences, 9:217-27, 1973. (Genesis of precambrian iron and manganese deposits - Proceeding Kiev Simposium, Paris, 1970).

SCHWARTZ, G.M. Classification and definitions of textures and mineral structures in ores. Econ.Geo1.,46(6):578-91, 1951.

SILVA,A.R. et al. Contribuição ao estudo dos protominērios de manganês do distrito de Serra do Navio, Território Federal do Amápá. Bol.Soc.Bras.Geol. , $12(1-2): 38-48,1963$.

SOREN,R.K. \& CAMERON,E.N. Manganese oxides and associated minerals of the Nsuta manganese deposits, Ghana, West Africa. Econ.Geol. , 55 (2):278-310, 1960 .

SOUZA,H.C. Ferro e manganès no ceará. Min.Met. , 3 (21):124, 1939. STRECKEISEN,A. et al. Classification and nomenclature of plutonic recommendations. N.Jb.Miner.Mh. 4: 149-64, 1973.

TONIATTI, G. \& BARBOSA,J. O manganês de Maraū (BA) : avaliação de reservas. Congresso Brasileiro de Geologia, 28\%. Aracajū, 1973. (Anais) v.2. p.421-30.

TURNEAURE,F.S. Metallogenetic provinces epochs. Econ.Geol., $\underline{1}: 38-98,1955$. (Special number of the $50^{\text {th }}$ anniversary).

TURNER,F.J. Metamorphic petrology, mineral and field aspects. McGraw-Hi11, New York, 1968. 403p.

VALARELLI,J.V. Contribuição à mineralogia do minërio de manganês de Serra do Navio, Amapä. Rio de Janeiro, DGM/DNPM,1966. p.83-98. (Avulso no 41).

- O minério de manganês de Serra do Navio, Amapā. São Paulo, 1967. (Tese de Doutorado - Faculdade de Filosofia,Ciências e Letras, USP). 
VALARELLI,J.V. et al. Manganese deposits of the Marau District, Bahia, Brazil. International Geological Congress, 25:. Sydney, Austrälia, 1976. (Abstracts no 3).

WINKLER,H.G.F. Petrogenesis of metamorphic rocks. 4.ed. New York, Springer-Verlag, 1976. $334 \mathrm{p}$.

WRIGHT,J.B. \& MCCURRY,P. First occurrence of manganese ores in Northern Nigëria. Econ. Geol., 65(2):103-6, 1970.

YAHNS,R.H. Clerici solution for the specific gravity determination of small mineral grains. Am. Min., 24(2):116-22,1939. 


\section{ANEXO I}

DESCRIÇÃO DE 17 POÇOS DAS REGIÕES DE SERRAGEM, LAGOA DO RIACHO E ALTO PRETO (ARACOIABA-CE) 
POÇO $S / N$ (Alto Preto)

PROFUNDIDADE

(em cm)

PERFII

TIPO DE ROCHA

$$
\begin{gathered}
0-100 \\
100-200 \\
200-390
\end{gathered}
$$$$
\left[\begin{array}{llll}
0 & 0 & 0 & 0 \\
0 & 0 & 0 \\
0 & 0 & 0 & 0 \\
0 & 0 & 0 & 0
\end{array}\right.
$$

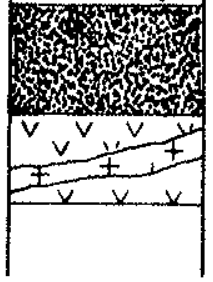

Canga manganesifera

Protominērio alterado em öxidos de Mn

Gnaisse cortado por pegmatito homogêneo

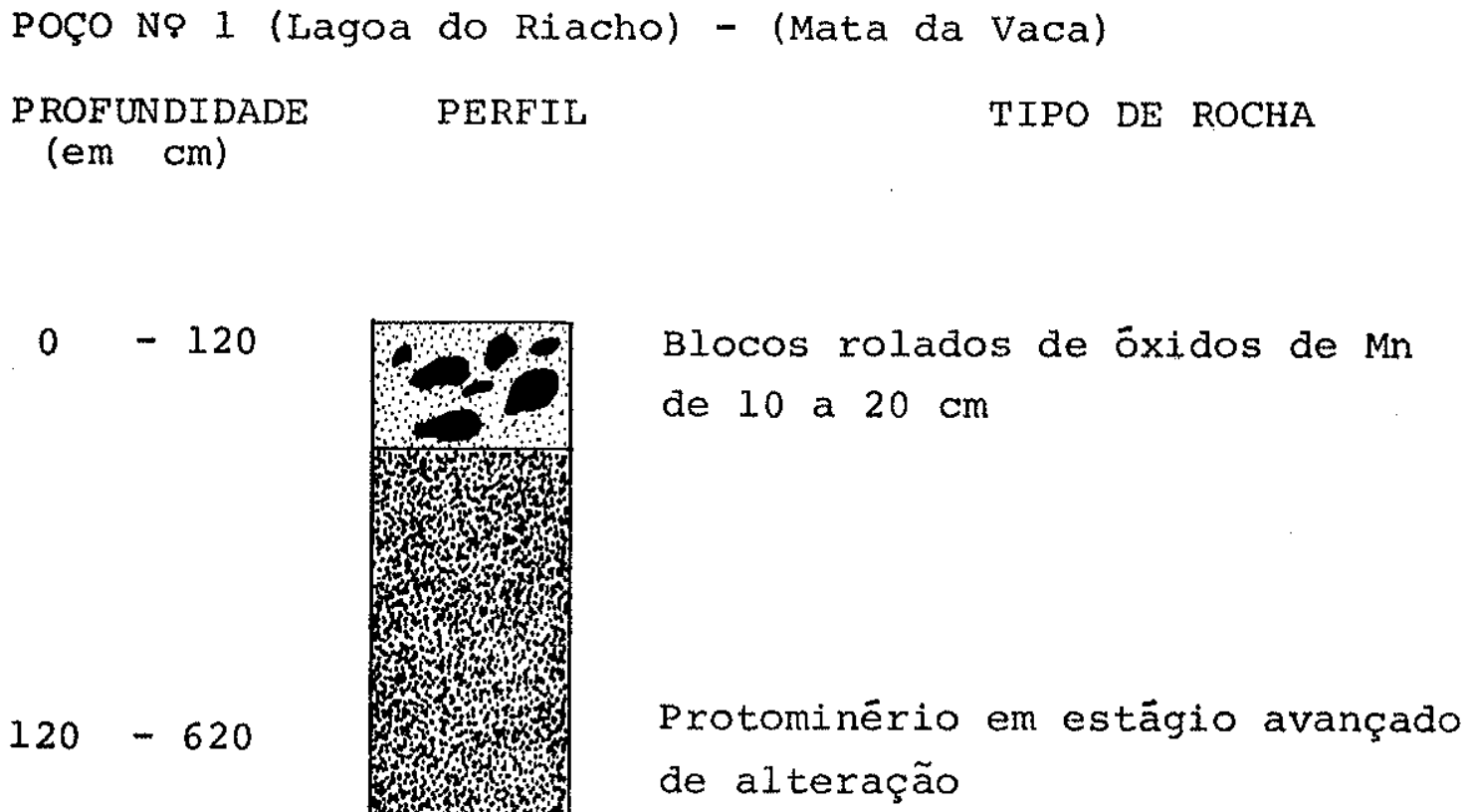

Blocos rolados de óxidos de $\mathrm{Mn}$ de 10 a $20 \mathrm{~cm}$

Protominērio em estägio avançado de alteração 
?ROFUNDIDADE

(em $\mathrm{cm}$ )

$0-350$

$350-700$

$700-800$
PERFIL

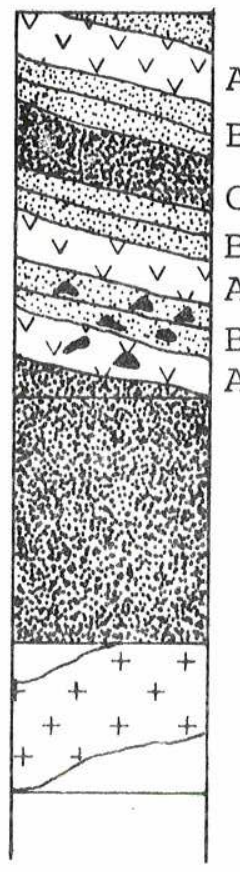

Protominërio em início de alteração

Pegmatito homogêneo
Este pacote sugere a existência de uma dobra em cujo núcleo central se encontra o protominério alterado:

$A=$ gnaisse decomposto

$\mathrm{B}=$ quartzito granatífero alterado

C = protominērio alterado
POÇO N\& 9 (Serragem)

ROFUNDIDADE

(em $\mathrm{cm}$ )
PERFIL
TIPO DE ROCHA
$300-330 \frac{C}{D}$

$330-410_{E}$

$410-510_{F}$

$510-660_{G}$

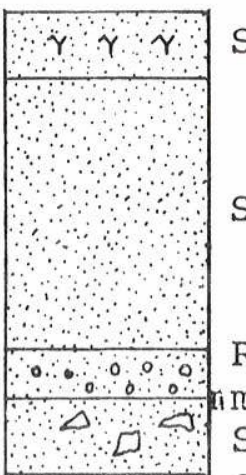

Solo edafisado, arenoso,granalução fina

Solo arenoso vermelho, (F.Barreira)

Rolados de Mn com estrutura concêntrica com diâmetro de 0,2 a $10 \mathrm{~cm}$ (RANZON) Solo coluvial, alteração de rochas metamörficas com grãos angulosos de 1 a $5 \mathrm{~cm}$ de diâmetro solo coluvial com blocos $>5 \mathrm{~cm}$

Solo areno-argiloso 
POÇO N\& 12 (Serragem)

\section{PROFUNDIDADE PERFIL \\ (em cm) \\ TIPO DE ROCHA \\ $0-230$
$230-350$
$350-550$
$550-650$

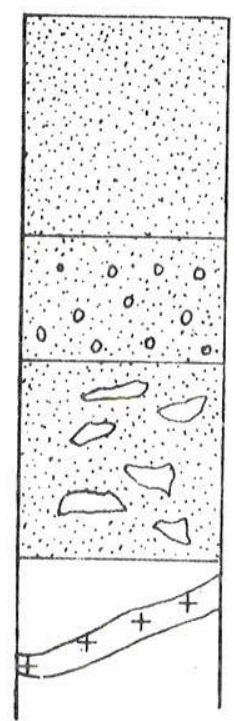 \\ Solo arenoso vermelho \\ Solo com rolados de $\mathrm{Mn}$, de estrutura concêntrica $0,2 \mathrm{~cm}$ a $10 \mathrm{~cm}$ de diâme- tro e blocos rolados de $\mathrm{Mn}$ \\ Solo proveniente de alteração de ro- chas metmörficas \\ Pegmatito homogêneo, alterado, com- posto de muscovita, quartzo, felds- pato e grafita}

POÇO N\& 13 (Serragern)

PROFUNDIDADE

PERFIL

(em $\mathrm{cm}$ )

TIPO DE ROCHA
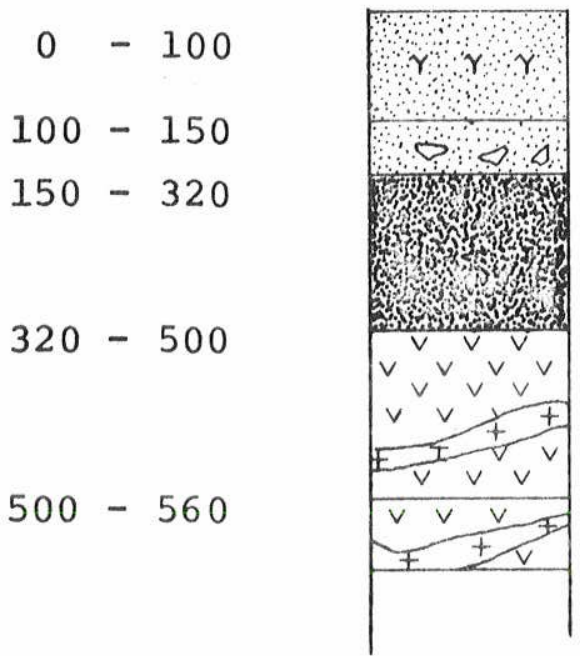

Solo edafisado

Blocos rolados de 10 a $20 \mathrm{~cm}$ de diâmetro Protominério quartzo-granatífero alterado, com mergulho da foliação de 40 a $50^{\circ} \mathrm{N}$

Gnaisse de granulação média, cortado por pegmatito homogêneo com o feldspato alterado para caulim

Gnaisse de granulação grosseira cortado por pegmatito alterado 
POÇO N\& 14 (Serragem)

PROFUNDIDADE
$\left(\begin{array}{ll}\text { em cm) } & \text { PERFIL }\end{array}\right.$ TIPO DE ROCHA

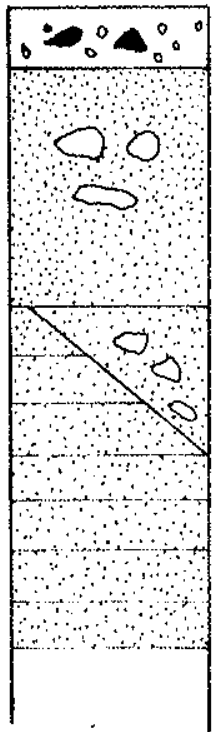

POÇO No 15 Serragem)

PROFUNDIDADE

(em $\mathrm{cm}$ )

PERFIL

Quartzito granatifero com impregnação
de óxidos de $M n$, com mergulho de $75^{\circ} \mathrm{NE}$

Quartzito granatifero com impregnação
de óxidos de Mn, com mergulho de $75^{\circ} \mathrm{NE}$
Blocos rolados de $\mathrm{Mn}$ de 0,5 a $10 \mathrm{~cm}$ de diâmetro

Rochas metamórficas alteradas

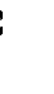

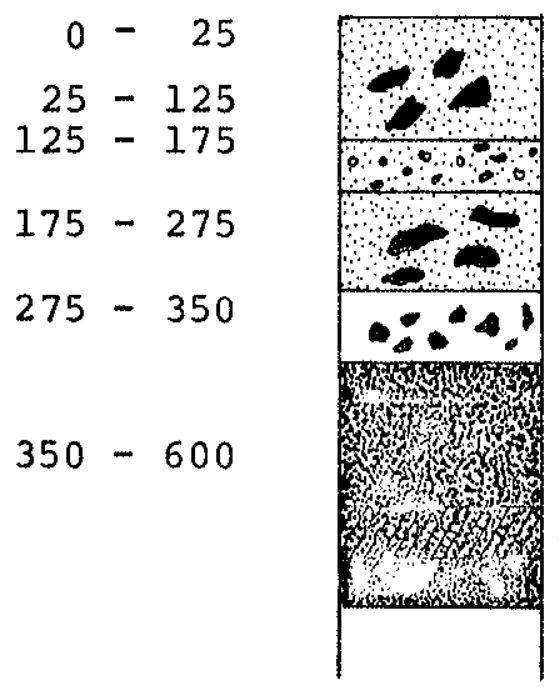


POÇO No 18 (Serragem)

PROFUNDIDADE PERFIL (em $\mathrm{cm}$ )

$0-140$

$140-320$

$320-460$

$460-660$

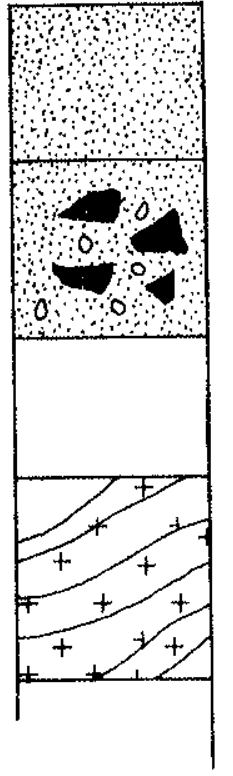

Solo arenoso vermelho (F.Barreiras)

Blocos rolados de 15 a $25 \mathrm{~cm}$ de protominério;esferas de 0,1 a $5 \mathrm{~cm}$ de diâmetro Zona intermediāria de gnaisse alterado in situ

Pegmatito homogêneo alterado com veios de quartzo preservados
POÇO No 19 (Serragem)

PROFUNDIDADE

(em cm)

$0-80$

$80-120$

$120-250$

$250-330$

$330-430$

$430-610$
PERFIL

TIPO DE ROCHA
Solo arenoso vermelho (F.Barreiras)

Blocos rolados de óxidos de $M$ n de 1 a $10 \mathrm{~cm}$ de comp. Dentro de blocos angul.de quartzo e feldspato. Quartzo e feldspatos alterados in situ;observam-se veios de quartzo preservados. A granulação varia de 10 a 20 cm de cima para baixo

solo arenoso verm. proveniente de alter.de rochas metmörf.c/Qz e felds.de 0,1 a $2 \mathrm{~cm}$.

Pegmatitos homogêneos, com preservação de veios de Qz de $25 \mathrm{~cm}$ de espes. ,com blocos achatados com maior comprimento

Pegmatitos homogêneos 
POço No 20 (Serragem)

PROFUNDIDADE

(em $\mathrm{cm}$ )

$0-40$

$40-140$

$140-490$

$490-980$

$980-1000$
PERFIL

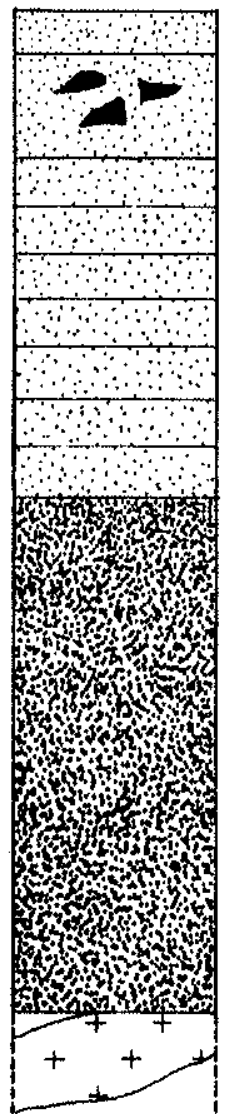

TIPO DE ROCHA

Solo arenoso vermelho (F.Barreira)

Blocos rolados de protominërio de Mn

Quartzito com granada e grafita alterado, manchado de óxido de Mn; Granulação mëdia.

Protominërio de Mn-Quartzito com espessartita, alterado com mergulho de foliação de $60^{\circ} \mathrm{E}$

Pegmatito homogêneo, com quartzo e feldspato apresentando estrutura gráfica

POÇO No 21 (Serragem)

PROFUNDIDADE

$\left(\begin{array}{ll}e m & c m\end{array}\right)$

$0-100$

$100-155$

$155-175$

$175-395$

$395-595$
PERFIL

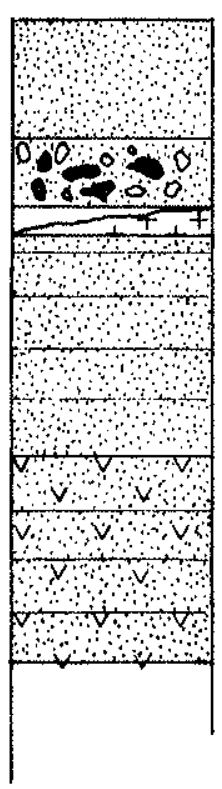

Solo arenoso vermelho (F.Barreira)

Blocos rolados de 5 a $20 \mathrm{~cm}$ de protominério de $\mathrm{Mn}$ Veio de quartzo leitoso

Solo proveniente de alteração de rochas quartzosas de granulação grosseira

Rochas metamörficas alteradas 
Poço N8 34 (Serragem)

PROFUNDIDADE PERFIL

TIPO DE ROCHA

(em cm)

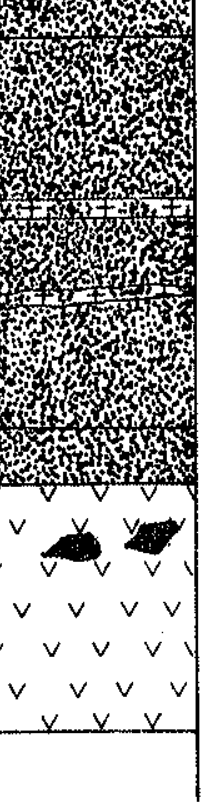

Afloramento de protominério alterado

$0-400$

Protominério pouco alterado, com veioscamadas de quartzo leitoso

$400-460$

Camada de protominërio alterado

$460-710$

Gnaisse alterado com mergulho de $70^{\circ} \mathrm{NE}$ e blocos rolados de manganês

POÇO N\& 37 (Serragem)

PROFUNDIDADE

(em cm)

PERFIL

$0-210$

$210-230$

$230-350$

$350-370$

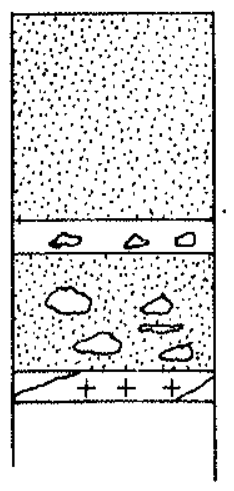

Solo arenoso vermelho (F.Barreiras)

Rolados de óxidos de $M n$ de 0,5 a $2 \mathrm{~cm}$ de diâmetro.

Rolalos de óxidos de $\mathrm{Mn}$ de 10 a $20 \mathrm{~cm}$ de diametróno 
POÇO No 38 (Serragem)

PROFUNDIDADE PERFIL

(em cm)

TIPO DE ROCHA

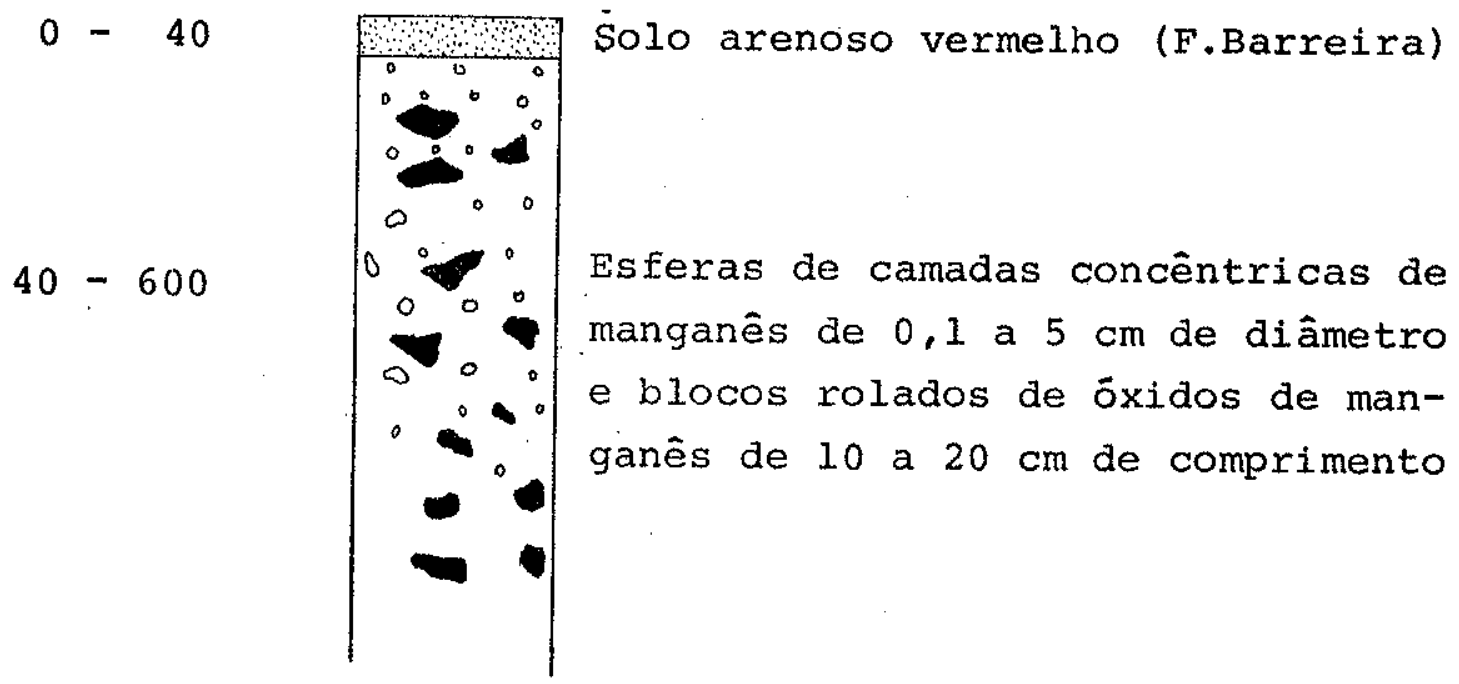

POÇO No 39 (Serragem)

PROFUNDIDADE

(em cm)

PERFIL

TIPO DE ROCHA

$0-100$

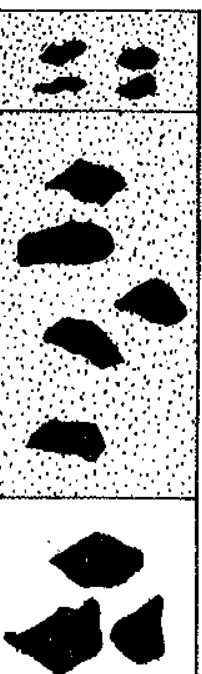

Blocos rolados de óxidos de manganês de 2 a $5 \mathrm{~cm}$ de comprimento

$100-500$

$500-730$

Blocos rolados de óxidos de manganês de 15 a $35 \mathrm{~cm}$ de comprimento

Blocos rolados de öxidos de manganês de 10 a $30 \mathrm{~cm}$ de comprimento 
POÇO No 42 (Serragem)

PROFUNDIDADE

(em $\mathrm{cm}$ )
PERFIL

TIPO DE ROCHA

$0-130$
$130-200$
$200-360$
$360-530$

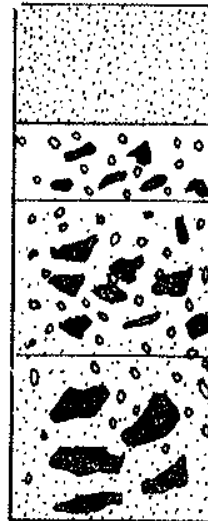

Solo arenoso vermelho (F.Barreira)

Esferas de camadas concêntricas de diâmetro de 0,1 a $5 \mathrm{~cm}$ e blocos rolados de $20 \mathrm{~cm}$ de comprimento

Esferas de camadas concêntricas em menor quantidade que blocos rolados de protominério de 10 a $20 \mathrm{~cm}$ de comprimento

Blocos rolados de protominërio alterados de 30 a $40 \mathrm{~cm}$ de comprimento; poucas esferas de camadas concêntricas e quartzos angulosos de 5 a $10 \mathrm{~cm}$ de comprimento 
ANEXO II

DESCRIÇÃO DE 4 FUROS DE SONDA DE SERRAGEM-ARACOIABA 
PERFIL DE FURO DE SONDA - SF-1 (Serragem)

Escala Vertical 1/100 - Mergulho $75^{\circ} \mathrm{NE}$

Baseado em dados de CRUzUL (1975)

Descrição de campo

m

$\begin{array}{lll}0 & 0 \\ 0 & 0\end{array}$

1,5

Blocos rolados de protominério de manganês e esferas concêntricas de óxidos de manganês

Protominério de manganês e granadarquartzito

Migmatito-gnaisse decomposto

Protominério granatífero

10,5

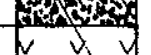

Protominexio granatifero

Migmatito-gnaisse decomposto

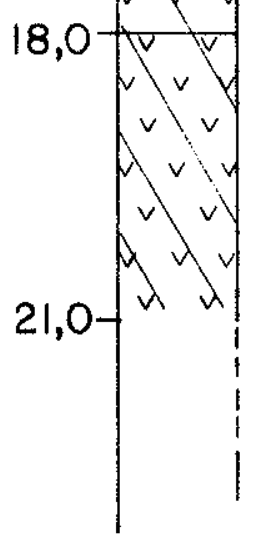

Migmatito-gnaisse fresco 
PERFIL DE FURO DE SONDA

SF-4 (Serragem)

Escala Vertical 1/100

Mergulho $75^{\circ} \mathrm{NE}$

Descrição de campo

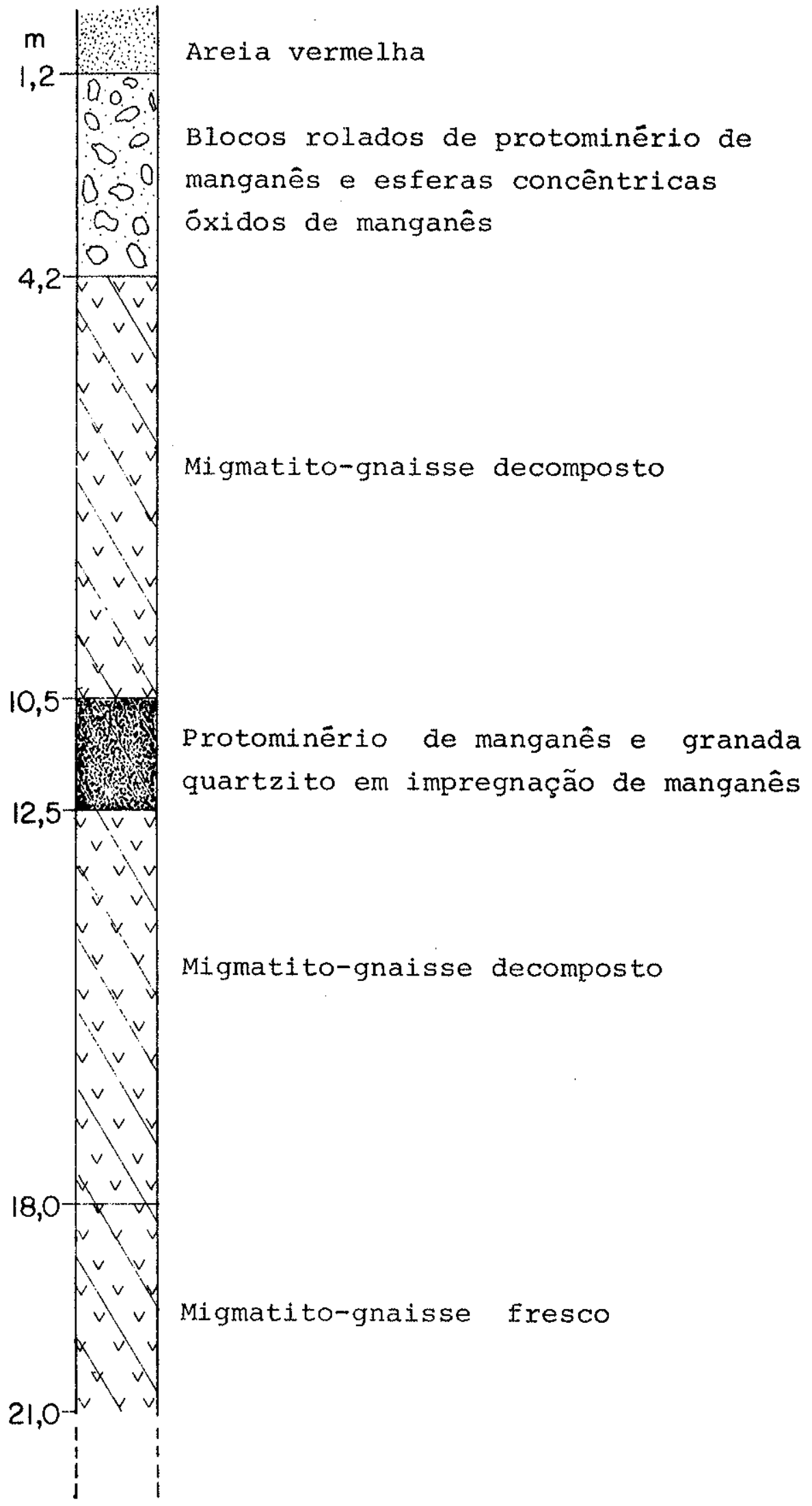


PERFIL DE FURO DE SONDA - SF-5 (Serragem)

Escala Vertical $1 / 100$ - Mergulho $75^{\circ} \mathrm{NE}$

Baseado em dados de CRUzuL (1975)

Descrição de campo

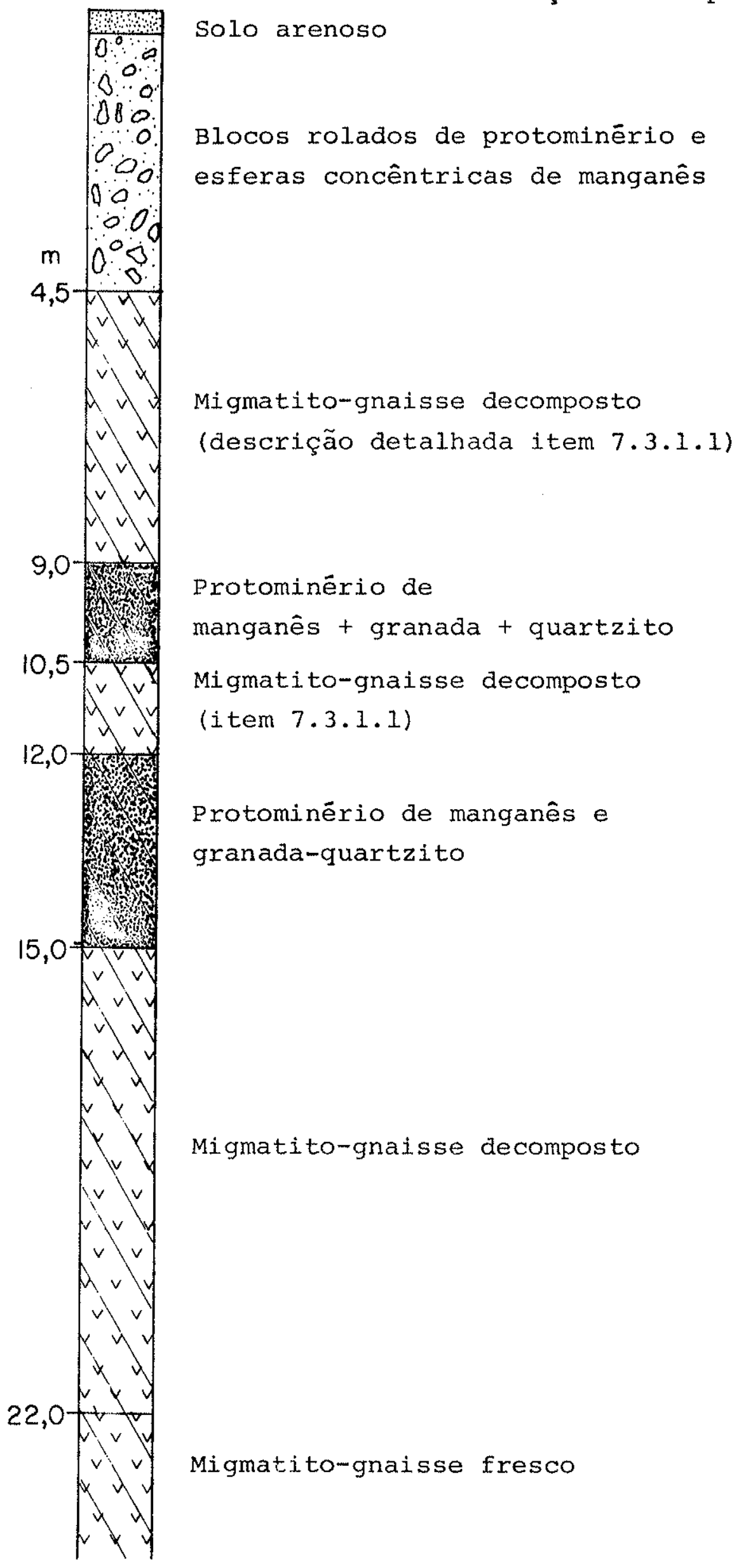


PERFIL DE FURO DE SONDA

$$
\text { SF-6 (Serragem) }
$$

Escala Vertical $1 / 100$

Mergulho $75^{\circ} \mathrm{NE}$

Baseado em dados da CRUZUL (1975)

Descrição de campo

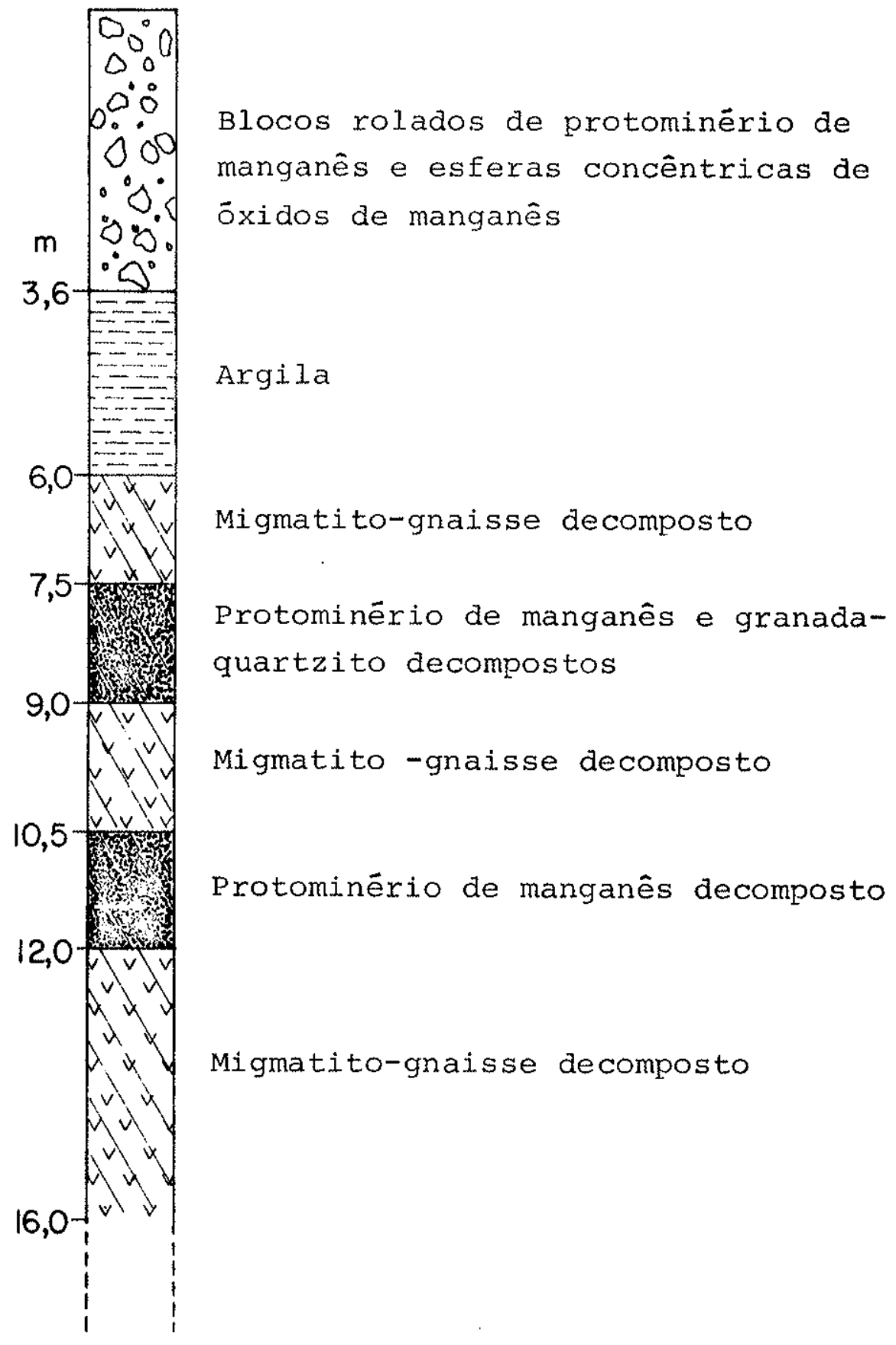


ANEXO III

DISTRIBUIÇÃO DE FREQÜÊNCIA DE TEORES DE Mn (\%) DE ROCHAS DA PROVINCIA DE ARACOIABA-PACAJOS (CE) 
DISTRIBUIÇÃO DE EREQUtÊNCIA DE RESULTADOS DE TEORES DE Mn (\%), RELATIVOS A AMOSTRAS DE PROTOMINERIO E MINERIO DA PROVINCIA MANGANESIFERA DE ARACOIABA-PACAJÚS, CEARA.

$\operatorname{DADOS}\left(\mathrm{x}_{1}\right)$

FREQUTENCIA (f)

FREQÜENCIA RELATIVA

CLASSE I

$\begin{array}{rll}8,24 & 1 & 0,66 \\ 8,51 & 1 & 0,66 \\ 8,64 & 1 & 0,66 \\ 8,65 & 2 & 1,32 \\ 9,13 & 1 & 0,66 \\ 9,19 & 1 & 0,66 \\ 9,37 & 1 & 0,66 \\ 10,10 & 1 & 0,66 \\ 10,30 & 1 & 0,66 \\ 10,50 & 1 & 0,66 \\ 10,70 & 1 & 0,66 \\ 11,00 & 1 & 0,66 \\ 12,10 & 1 & 0,66\end{array}$

CLASSE II

$\begin{array}{lll}13,00 & 1 & 0,66 \\ 13,10 & 2 & 1,32 \\ 13,40 & 2 & 1,32 \\ 14,10 & 2 & 1,32 \\ 14,30 & 1 & 0,66 \\ 14,60 & 1 & 0,66 \\ 14,70 & 2 & 0,66 \\ 14,80 & 1 & 0,66 \\ 14,60 & 1 & 0,66 \\ 14,90 & 1 & 0,66 \\ 15,10 & 3 & 2,00 \\ 15,50 & 1 & 0,66 \\ 15,60 & 3 & 2,00 \\ 15,70 & 1 & 0,66 \\ 16,10 & 2 & 2,00 \\ 16,20 & 1 & 0,66\end{array}$

OBSERV.: Dados extraídos da CRUZUM (1975) ; amostras analisadas pelo laboratōrio Supervise-Sociedade Brasileira de Superintendência S/A - Rio de Janeiro. 
DAdOS $\left(x_{1}\right)$

FREQUENCIA (f)

FREQUENCIA RELATIVA

CLASSE II

16,30

16,40

16,50

17,00

17,10

17,30

17,40

17,70

17,90

18,10

18,30

18,40

18,50

18,70

18,90

19,00

19,20

19,30

19,50

19,60

19,70

19,90

20,10

20,20

20,50

20,90

21,20

21,50

21,70

21,80
2

2

2

1

2

1

1

2

1
1,32

1,32

1,32

0,66

1,32

0,66

0,66

1,32

0,66

CLASSE III

1

I

1

1

1

3

1

1

2

1

1

1

1

1

2

1

2

1

2

1

1
0,66

0,66

0,66

0,66

0,66

2,00

0,66

0,66

1,32

0,66

0,66

0,66

0,66

0,66

1,32

0,66

1,32

0,66

1,32

0,66

0,66 
DADOS $\left(\mathrm{x}_{1}\right)$

FREQUUÊNCIA (f)

FREQUUENCIA RELATIVA

CLASSE III

$\begin{array}{ll}22,00 & 1 \\ 22,10 & 2 \\ 22,30 & 1 \\ 22,40 & 1 \\ 22,50 & 1\end{array}$

1

2

1

1

1

CLASSE IV

23,20

23,40

23,50

23,60

23,70

23,90

24,00

24,20

24,30

24,50

24,60

24,70

25,30

25,40

25,70

25,90

26,30

26,80

26,90

27,10

27,20

27,30

27,60

27,70

27,80
2

1

1.

3

1

1

1

1

1

1

2

1

1

1

1

1

1

1

1

1

3

1

1

1

1
0,66

1,32

0,66

0,66

0,66

1,32

0,66

0,66

2,00

0,66

0,66

0,66

0,66

0,66

0,66

1,32

0,66

0,66

0,66

0,66

0,66

0,66

0,66

0,66

0,66

2,00

0,66

0,66

0,66

0,66 


\section{CLASSE V}

$\begin{array}{lll}28,00 & 1 & 0,66 \\ 28,10 & 1 & 0,66 \\ 28,20 & 1 & 0,66 \\ 28,80 & 1 & 0,66 \\ 29,00 & 1 & 0,66 \\ 29,30 & 1 & 0,66 \\ 29,60 & 2 & 1,32 \\ 29,70 & 1 & 0,66 \\ 30,00 & 1 & 0,66 \\ 30,30 & 2 & 1,32 \\ 30,70 & 1 & 0,66 \\ 31,00 & 1 & 0,66 \\ 31,20 & 1 & 0,66 \\ 32,10 & 1 & 0,66 \\ 32,50 & 1 & 0,66\end{array}$

CLASSE VI

33,20

33,80

34,70

34,80

35,50

35,60

35,70

37,50

37,50
1

3

1

2

1

2

1

1

1
0,66

2,00

0,66

1,32

0,66

1,32

0,66

0,66

0,66

CIASSE VII

F

0,00

CLASSE VIII

45,80

1

0,66

1

0,66 
ANEXO IV

CALCULO DE $a_{0}$ A PARTIR DE FILMES DE RAIOS-X 
METODO ANALITICO (MEDIA PONDERADA DOS VALORES DA CELA UNITARIA PELAS REFLEXÕES DE BRAGG) PARA CALCULO DO a ROFF, 1958) PARA A GRANADA DO MIGMATITO-GNAISSE DA REGIÃO DE SERRAGEM-ARACOIABA-CE

\begin{tabular}{|c|c|c|c|c|c|c|c|c|c|c|}
\hline $\begin{array}{l}\text { NQ DE } \\
\text { ORDEM. }\end{array}$ & $2 Q(\mathrm{Fe})$ & I/Io & $\mathrm{d} \AA$ & $h k 1$ & $\mathrm{NC}$ & $Q(h k 1)$ & $a^{*^{2}}$ observado & $\mathrm{Da} \star^{2}=\Delta$ & $\left(\Delta^{2}\right)$ & $\Delta^{2} \cdot N c$ \\
\hline 1 & 38,98 & 50 & 2,90 & 400 & 16 & 0,118906 & 0,007431 & 41 & 1681 & 26896 \\
\hline 2 & 43,78 & 100 & 2,54 & 420 & 20 & 0,155000 & 0,007750 & -278 & 77284 & 1545680 \\
\hline 3 & 48,23 & 10 & 2,36 & 422 & 24 & 0,179546 & 0,007481 & -9 & 81 & 1944 \\
\hline 4 & 50,23 & 10 & 2,28 & 431 & 26 & 0,192366 & 0,007398 & 74 & 5476 & 142376 \\
\hline 5 & 54,33 & 10 & 2,12 & 521 & 30 & 0,222499 & 0,007408 & 74 & 4096 & 122880 \\
\hline 6 & 70,43 & 10 & 1,67 & 444 & 48 & 0,358564 & 0,007470 & 2 & 4 & 192 \\
\hline 7 & 61,83 & 20 & 1,88 & 532 & 38. & 0,282933 & 0,007445 & 27 & 729 & 27702 \\
\hline 8 & 77,13 & 60 & 1,55 & 642 & 56 & 0,416233 & 0,007432 & 40 & 1600 & 89600 \\
\hline 9 & 83,63 & 5 & 1,45 & 800 & 64 & 0,475624 & 0,007416 & 56 & 3136 & 200704 \\
\hline 10 & 95,43 & 10 & 1,30 & 840 & 80 & 0,591715 & 0,007396 & 76 & 5776 & 462080 \\
\hline \multirow[t]{2}{*}{11} & 132,03 & 5 & 1,05 & 10.4 .2 & 120 & 0,907029 & 0,007558 & -86 & 7396 & 887520 \\
\hline & & & & & 522 & 3,900415 & 0,007472 & & 107259 & 3507574 \\
\hline
\end{tabular}

cälculo do erro

$$
\begin{aligned}
& E a \star^{2}= \pm \sqrt{\frac{3507574 \cdot 10^{-12}}{522(11-1)}} \\
& E a \star^{2}= \pm \frac{1872,85 \cdot 10^{-6}}{\sqrt{5220}}=\frac{1872,85 \cdot 10^{-6}}{72,24} \\
& E a \star^{2}= \pm 2.10^{-5} \\
& a \star^{2} \text { calculado }=0,007472
\end{aligned}
$$

Cálculo do a o

$$
\begin{aligned}
& a_{0}= \pm \sqrt{\frac{1}{a \star^{2} \mathrm{calc}}} \frac{\sqrt{\frac{1}{a \star^{2} \mathrm{calc}+E a \star^{2}}}-\sqrt{\frac{1}{a^{2} \mathrm{calc}-E a \star^{2}}}}{2} \\
& a_{0}=\frac{1}{0,007472} \pm \frac{\sqrt{\frac{1}{0,007472+0,00002}}-\sqrt{\frac{1}{0,007436-0,00002}}}{2}-\frac{1}{\frac{\sqrt{0,086556}}{\sqrt{0,086324}}} \\
& a_{0}=\frac{1}{0,086440} \pm a_{0}=11,5687 \pm \frac{11,5532-11,5842}{2} \\
& a_{0}=11,5687 \pm \frac{0,031}{2}
\end{aligned}
$$

$a_{0}=11,5687 \pm 0,015$ 
DO ANALITICO (MEDIA PONDERADA DOS VALORES DA CELA UNITARIA PELAS REFLEXÕES DE BRAGG) PARA CALLULO DO a PARA A GRANADA DO GRANADA-QUARTZITO DA REGI AO DE SERRAGEM-ARACOIABA-CE

\begin{tabular}{|c|c|c|c|c|c|c|c|c|c|}
\hline $2 \theta(\mathrm{Fe})$ & I/IO & $\mathrm{d} \AA$ & $h k 1$ & $\mathrm{NC}$ & $Q(h k l)$ & $a \star^{2}$ observado & $\mathrm{Da} \star^{2}=\Delta$ & $\left(\Delta^{2}\right)$ & $\Delta^{2} \cdot N C$ \\
\hline 38,80 & 80 & 2,91 & 400 & 16 & 0,118090 & 0,007380 & 56 & 3136 & 50176 \\
\hline 43,65 & 100 & 2,60 & 420 & 20 & 0,147929 & 0,007396 & 40 & 1600 & 32000 \\
\hline 45,90 & 10 & 2,48 & 332 & 22 & 0,162591 & 0,007390 & 46 & 2116 & 46552 \\
\hline 48,01 & 30 & 2,37 & 422 & 24 & 0,178034 & 0,007418 & 18 & 324 & 7776 \\
\hline 50,15 & 20 & 2,28 & 431 & 26 & 0,192367 & 0,007399 & 37 & 1369 & 35594 \\
\hline 54,20 & 20 & 2,12 & 521 & 30 & 0,222499 & 0,007416 & 20 & 400 & .12000 \\
\hline 56,35 & 20 & 2,05 & 440 & 32 & 0,237953 & 0,007436 & 00 & 0000 & 0000 \\
\hline 61,70 & 50 & 1,88 & 532 & 38 & 0,282933 & 0,007445 & -9 & 81 & 3078 \\
\hline 70,40 & 60 & 1,67 & 444 & 48 & 0,358564 & 0,007480 & -34 & 1156 & 55488 \\
\hline 73,70 & 80 & 1,61 & 640 & 52 & 0,385787 & 0,007418 & 18 & 324 & 16848 \\
\hline 75,95 & 30 & 1,57 & 552 & 54 & 0,405695 & 0,007512 & -76 & 5776 & 311904 \\
\hline 83,40 & 20 & 1,45 & 800 & 64 & 0,475624 & 0,007431 & 5 & 25 & 1600 \\
\hline 96,20 & 30 & 1,30 & 840 & 80 & 0,591715 & 0,007396 & 40 & 1600 & 128000 \\
\hline 99,40 & 20 & 1,26 & 842 & 84 & 0,629881 & 0,007498 & -62 & 3844 & 322895 \\
\hline 102,50 & 10 & 1,24 & 664 & 88 & 0,650364 & 0,007390 & 46 & 2116 & . 186208 \\
\hline 104,10 & 5 & 1,22 & 754 & 90 & 0,671862 & 0,007465 & -29 & 841 & 75690 \\
\hline 110,75 & 10 & 1,17 & 853 & 98 & 0,730513 & 0,007454 & -18 & 324 & 31752 \\
\hline 120,50 & 5 & 1,14 & 862 & 104 & 0,769467 & 0,007398 & 38 & 1444 & 150176 \\
\hline 127,00 & 60 & 1,08 & 10.4 .0 & 116 & 0,857338 & 0,007391 & 45 & 2025 & 234900 \\
\hline 137,05 & 40 & 1,06 & 10.4 .2 & 120 & 0,889996 & 0,007416 & 20 & 400 & 48000 \\
\hline 140,15 & 40 & 1,02 & 880 & 128 & 0,961168 & 0,007509 & -73 & 5329 & 682112 \\
\hline & & & & 1334 & 9,920370 & 0,007436 & -153 & & 2432749 \\
\hline
\end{tabular}

culo do erro

$\mathrm{Ea}^{2}= \pm \sqrt{\frac{\sum\left(\mathrm{Da} \star^{2}\right)^{2} \cdot \mathrm{NC}}{\sum \mathrm{NC}(\mathrm{n}-1)}}$
$\mathrm{Ea}{ }^{\star}= \pm \sqrt{\frac{2432749 \cdot 10^{-12}}{1334(21-1)}}$

Cálculo do $a_{0}$

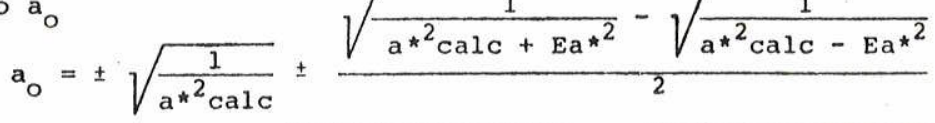

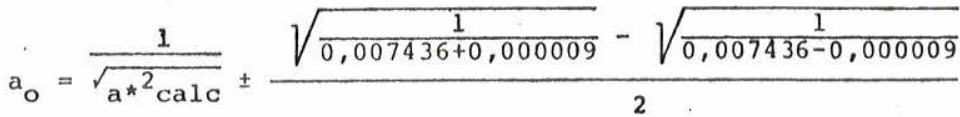

$$
\begin{aligned}
& a_{0}=\frac{1}{\sqrt{0,007436}} \pm \frac{\sqrt{\frac{1}{0,007445}}-\sqrt{\frac{1}{0,007427}}}{2} \\
& a_{0}=\frac{1}{\sqrt{0,007436}} \pm \frac{\frac{1}{0,086284}-\frac{1}{0,086180}}{2} \\
& a_{0}=\frac{1}{0,086232} \pm \frac{11,589-11,603}{2} \\
& a_{0}=11,596 \pm \frac{0,014}{2} \\
& a_{0}=11,596 \pm 0,007
\end{aligned}
$$

